\title{
FLUOR DANIEL HANFORD IMPLEMENTATION PLAN FOR DOE ORDER 5480.28 NATURAL PHENOMENA HAZARDS MITIGATION
}

Project Hanford Management Contractor for the

U.S. Department of Energy under Contract DE-AC06-96RL13200

Approved for public release; distribution is unlimited 


\section{Fluor Daniel Hanford Implementation Plan for DOE Order 5480.28 \\ Natural Phenomena Hazards Mitigation}

T. J. Conrads

Numatec Hanford Corportion

September 1997 
LEGAL DISCLAIMER

This report was prepared as an account of work sponsored by an agency of the United States Government. Neither the United States Government nor any agency thereof, nor any of their employees, nor any of their contractors, subcontractors or their employees, makes any warranty, express or implied, or assumes any legal liability or responsibility for the accuracy, completeness, or any third party's use or the results of such use of any information, apparatus, product, or process disclosed, or represents that its use would not infringe privately owned rights. Reference herein to any specific commercial product, process, or service by trade name, trademark, manufacturer, or otherwise, does not necessarily constitute or imply its endorsement, recommendation, or favoring by the United States Government or any agency thereof or its contractors or subcontractors. The views and opinions of authors expressed herein do not necessarily state or reflect those of the United States Government or any agency thereof.

This report has been reproduced from the best available copy. Avallable in paper copy and microfiche.

Available to the U.S. Department of Energy and its contractors from

U.S. Department of Energy

Office of Scientific and Technical Information (OSTI)

P.O. Box 62

Oak Ridge, TN 37831

(615) $576-8401$

Printed in the United States of America 


\section{RELEASE AUTHORIZATION}

Document Number:

Document

Title:
HNF-SP-1175, Rev. 0

Fluor Daniel Hanford Implementation Plan for DOE

Order 5480.28 Natural Phenoena Hazards Mitigation

Release Date: $\quad 9 / 12 / 97$

This document was reviewed following the procedures described in WHC-CM-3-4 and is: APPROVED FOR PUBLIC RELEASE

WHC Information Release Administration Specialist:

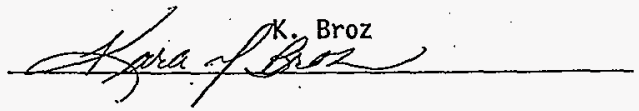




\section{EXECUTIVE SUMMARY}

Natural phenomena hazards (NPH) are unexpected acts of nature that pose a threat or danger to workers, the public, or the environment. Earthquakes, extreme winds (hurricane and tornado), snow, flooding, volcanic ashfall, and lightning strikes are examples of NPH that could occur at the Hanford Site.

U.S. Department of Energy (DOE) policy requires facilities to be designed, constructed, and operated in a manner that protects workers, the public, and the environment from hazards caused by natural phenomena.

DOE Order 5480.28, Natural Phenomena Hazards Mitigation, includes rigorous new natural phenomena criteria for the design of new DOE facilities, as well as for the evaluation and, if necessary, upgrade of existing DOE facilities. The Order was transmitted to Westinghouse Hanford Company in 1993 for compliance and is also identified in the Project Hanford Management Contract, Section J, Appendix C. Criteria and requirements of DOE Order 5480.28 are included in five standards, the last of which, DOE-STD-1023, was released in fiscal year 1996.

Because the Order was released before all of its required standards were released, enforcement of the Order was waived pending release of the last standard and determination of an in-force date by DOE Richland Operations Office (DOE-RL). Agreement also was reached between the Management and Operations Contractor and DOE-RL that the Order would become enforceable for new structures, systems, and components (SSCS) 60 days following issue of a new order-based design criteria in HNF-PR0-97, Engineering Design and Evaluation. The order also requires that commitments addressing existing SSCS be included in an implementation plan that is to be issued 1 year following the release of the last standard. Subsequent1y, WHC-SP-1175, Westinghouse Hanford Company Implementation Plan for DOE Order 5480.28, Natural Phenomena Hazards Mitigation, Rev. 0, was issued in November 1996, and this document, HNF-SP-1175, Fluor Daniel Hanford Implementation P7an for DOE Order 5480.28, Natural Phenomena Hazards Mitigation, is Rev. 1 of that plan.

DOE Order 420.1, Facility Safety, issued in 1995, contains the same natural phenomena hazards requirements and invokes the same applicable 
standards as DOE Order 5480.28 for natural phenomena hazards. DOE Order 420.1 wi11 supersede DOE Order 5480.28 when an in-force date is established through contract revision.

The Project Hanford Management Contract is implementing a phased and graded approach for compliance with DOE Order 5480.28 through this implementation plan. Activities will be planned and accomplished in four phases.

- Mobilization. Development of natural phenomena hazards structural design criteria for new and existing facilities.

- Prioritization. Prioritization of existing facilities, issuance of the implementation $\mathrm{plan}$ required by DOE Order 5480.28, and compliance for new facilities.

- Evaluation. Evaluation of natural phenomena hazards vulnerability of the most important existing facilities (based on the existing facility prioritization).

- Upgrade. Upgrade of facilities, if necessary, when justified by a risk-benefit analysis.

The planned activities (as well as the level of depth, rigor, and thoroughness in accomplishing them) are determined by applying a graded approach. The basis for the graded approach is the designation of facilities/structures into one of five performance categories based on safety function, mission, and cost.

The mobilization phase was completed with the draft of WHC-CM-1-12, which became HNF-PRO-97. Rev. 0 of the implementation $\mathrm{plan}$ developed the program for the prioritization phase and a follow-on strategy for the implementation of DOE Order 5480.28 . HNF-SP-1175 includes a partially prioritized list of existing buildings and structures planned for future evaluation of natural phenomena hazards and suspends future implementation activities for existing structures, systems, and components. This suspension of activities is 
HNF-SP-1175

necessary because of funding priorities for the Project Hanford Management contract. 
HNF-SP-1175

This page intentionally left blank. 
HNF-SP-1175

CONTENTS

1.0 IMPLEMENTATION PLAN SUMMARY . . . . . . . . . . . 1 1-1

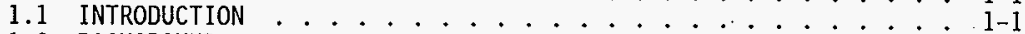

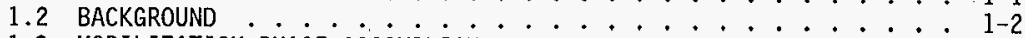

1.3 MOBILIZATION PHASE ACCOMPLISHMENTS $\ldots . . . \cdots 1-2$

1.4 PRIORITIZATION PHASE ACCOMPLISHMENTS $\ldots . . \cdots 1 . . . \cdots$

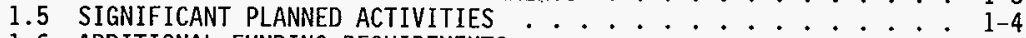

1.6 ADDITIONAL FUNDING REQUIREMENTS . . . . . . . .

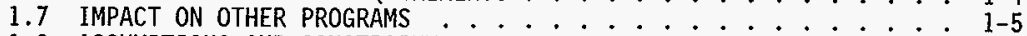

1.8 ASSUMPTIONS AND CONSTRAINTS . . . . ......... $1-5$

1.9 AREAS CURRENTLY IN FULL COMPLIANCE $\ldots \ldots$

1.10 REQUESTS FOR EXEMPTIONS, DEVIATIONS, AND WAIVERS $\ldots \ldots \ldots 1-5$

2.0 GENERAL INFORMATION .................. 2-1

2.1 SCOPE OF THE IMPLEMENTATION PLAN .................

2.2 CONTENT AND FORMAT OF THE PLAN .............

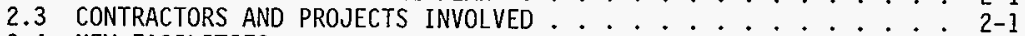

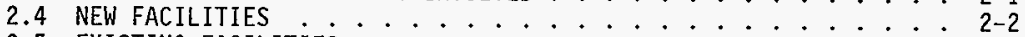

2.5 EXISTING FACILITIES . . . . . . . . . . . .

3.0 APPLICABILITY OF DOE REQUIREMENTS ........... . . . . 3-1

3.1 APPLICABLE REQUIREMENTS AND PROPOSED EXEMPTIONS $\cdots \cdots$

3.2 REQUIREMENTS THAT ARE NOT APPLICABLE AND JUSTIFICATION $\cdots 3-1$

3.3 APPLICABLE REQUIREMENTS AND ACHIEVED COMPLIANCE $\ldots . . . \quad 3-2$

3.4 APPLICABLE REQUIREMENTS AND PLANNED COMPLIANCE $\ldots . . . .3-2$

4.0 IMPLEMENTATION GUIDES AND TECHNICAL STANDARDS ......... $4-1$

4.1 DOE IMPLEMENTATION GUIDES AND STANDARDS $\ldots \ldots$

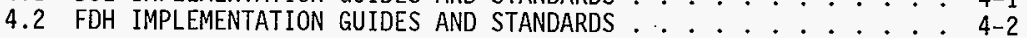

5.0 COMPLIANCE BASELINE ..................... 5-1

5.1 ESTABLISH THE COMPLIANCE BASEL INE ..........

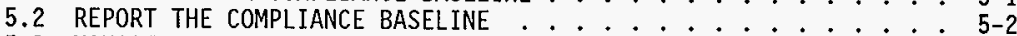

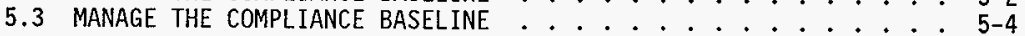

6.0 COMMITMENTS ...................... . . . . . . . .

6.1 MOBILIZATION PHASE COMMITMENTS $\cdots \cdots$

6.2 PRIORITIZATION PHASE COMMITMENTS $\ldots . . \cdots 6-1$

6.3 EVALUATION PHASE COMMITMENTS ................... $6-2$

6.4 UPGRADE PHASE COMMITMENTS .......................

7.0 GRADED APPROACH ...................... . . . . . . . .

7.1 NATURAL PHENOMENA HAZARD ASSESSMENT AND CHARACTERIZATION $: \cdots 7-1$

7.2 PERFORMANCE CATEGORIES ...........

7.3 DESIGN AND EVALUATION CRITERIA $\cdots$

7.4 NATURAL PHENOMENA HAZARD DETECTION AND POST-NATURAL

PHENOMENA HAZARD PROCEDURES .......... $7-3$

7.5 RESOURCE ASSESSMENT $\ldots \ldots \ldots$

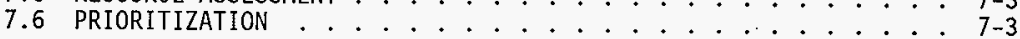




\section{CONTENTS}

8.0 PRIORITIZATION ...................... . . . . . .

8.1 PRIORITIZATION PROCESS .............. . . 8-1

8.2 WORKSHEET DEVELOPMENT . . . . . . . . . . . . 8-1

8.3 PRIORITIZATION SCHEDULE .............. 8- . . .

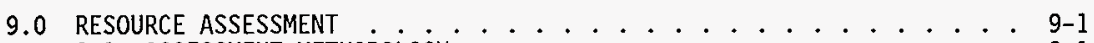

9.1 ASSESSMENT METHODOLOGY . . . . . . . . . . . . . 9-1

9.2 MOBILIZATION PHASE RESOURCE ASSESSMENT $\ldots \ldots \ldots . \ldots . . . . . .99$

9.3 PRIORITIZATION PHASE RESOURCE ASSESSMENT . . . . . . . . . 9-3

9.4 EVALUATION PHASE RESOURCE ASSESSMENT . . . . . . . . . . . 9-3

9.5 UPGRADE PHASE RESOURCE ASSESSMENT . . . . . . . . . 9-5

10.0 MILESTONES AND SCHEDULES .............. . . . 10-1

10.1 MOBILIZATION PHASE MILESTONES AND SCHEDULE ........ . . 10-1

10.2 PRIORITIZATION PHASE MILESTONES AND SCHEDULE . ....... $10-1$

10.3 EVALUATION PHASE MILESTONES AND SCHEDULE . . . . . . . . 10-1

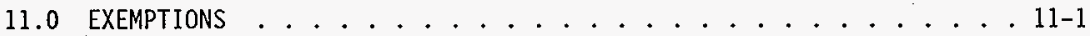

12.0 COMPENSATORY ACTIONS . . . . . . . . . . . . 12-1

12.1 NEW FACILITIES/SSCS ............... . . . . . . . . .

12.2 EXISTING BUILDINGS AND STRUCTURES $\ldots . . . . . . . .12-1$

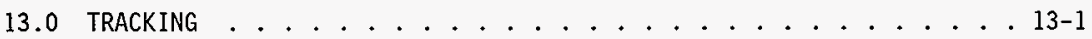

14.0 REFERENCES . . . . . . . . . . . . . . . . 14-1

14.1 REQUIREMENTS DOCUMENTS ................. . . . . . . .

14.2 OTHER REFERENCES ....................... . . . . . . . . . . . .

APPENDIXES

A COMPLIANCE BASELINE FOR NEW AND EXISTING BUILDINGS AND STRUCTURES IN COMPLIANCE WITH DOE ORDER $5480.28 \ldots \ldots . . . \ldots$. . . . . . .

B COMPLIANCE BASELINE FOR EXISTING BUILDINGS AND STRUCTURES WHERE AN EXEMPTION OR DEVIATION IS BEING REQUESTED . . . . . . . B B-1

C COMPLIANCE BASELINE AND PRIORITIZATION SCHEDULE FOR EXISTING BUILDINGS AND STRUCTURES REQUIRING NATURAL PHENOMENA HAZARDS EVALUATION ....................

D COMPLIANCE BASELINE FOR EXISTING BUILDINGS AND STRUCTURES THAT ARE CANDIDATES FOR UPGRADE .............. . . . 
HNF-SP-1175

FIGURES

5-1 Basel ine Management Process . . . . . . . . . . . 5-7

6-1 Naturai Phenomena Hazards Evaluation Report . . . . . . . 6-4

\section{TABLES}

2-1 Inventory of Existing Buildings and Structures ........ 2-3

3-1 Master Compliance Matrix for DOE Order 5480.28 (6 sheets) . . . . . 3-3

5-1 Facilities Natural Phenomena Hazard Compliance Database Structure ............... 5- . . 5

6-1 Natural Phenomena Hazards Evaluation Report . . . . . . . . 6-4

7-1 Graded Approach and Performance Categorization . . . . . . . . . 7-4

8-1 Natural Phenomena Hazards Prioritization Worksheet . . . . . . . . 8-2

8-2 Prioritization Scores for Inherently Rugged Facilities . . . . 8-8

8-3 Federal Emergency Management Agency Exemption Criteria . . . . . 8-9

9-1 Bases for Assessment . . . . . . . . . . . . . 9-3

10-1 Completed Prioritization Phase Milestones and Schedule . . . . . 10-2

10-2 Proposed Evaluation Phase Milestones and Schedule . . . . . 10-3

11-1 FEMA Exemptions ................. . . . . . . . . . . 


\section{TERMS}

$\begin{array}{ll}\text { ATC } & \text { Applied Technology Council } \\ \text { BWHC } & \text { Babcock and Wilcox Hanford Company } \\ \text { DESH } & \text { Duke Engineering and Services Hanford } \\ \text { DNA } & \text { does not apply } \\ \text { DOE } & \text { U.S. Department of Energy } \\ \text { DYN } & \text { Dyncorp Tri-Cities Services } \\ \text { EO } & \text { Executive Order } \\ \text { ER } & \text { Evaluation Report } \\ \text { FDH } & \text { Fluor Daniel Hanford, Inc. } \\ \text { FEMA } & \text { Federal Emergency Management Agency } \\ \text { FFF } & \text { Fuel Fabrication Facilities } \\ \text { FFTF } & \text { Fast Flux Test Facility } \\ \text { FY } & \text { fiscal year } \\ \text { GPF } & \text { General Purpose Facilities } \\ \text { LMHC } & \text { Lockheed Martin Hanford Corporation } \\ \text { ICSSC } & \text { Interagency Committee on Seismic Safety in Construction } \\ \text { NPH } & \text { natural phenomena hazards } \\ \text { NHC } & \text { Numatec Hanford Corporation } \\ \text { PC } & \text { performance category } \\ \text { PFP } & \text { Plutonium Finishing Plant } \\ \text { PHMC } & \text { Project Hanford Management Contract } \\ \text { PSO } & \text { Program Secretarial Officer } \\ \text { PUREX } & \text { Plutonium-Uranium Extraction Facility } \\ \text { PW } & \text { Prioritization Worksheet } \\ \text { RL } & \text { U.S. Department of Energy, Richland Operations office } \\ \text { SAR } & \text { safety analysis report } \\ \text { SEN } & \text { Secretary of Energy Notice } \\ \text { SNF } & \text { Spent Nuclear Fuels } \\ \text { SSC } & \text { structures, systems, and components } \\ \text { STAB } & \text { Facility Stabilization } \\ \text { TWRS } & \text { Tank Waste Remediation System } \\ \text { UBC } & \text { Uniform Building Code } \\ \text { UR } & \text { Upgrade Report } \\ \text { WRAP 1 } & \text { Waste Receiving and Packaging Facility Module 1 } \\ \text { WESF } & \text { Waste Encapsulation Storage Facility } \\ \text { WHC } & \text { Westinghouse Hanford Comany } \\ \text { WMH } & \text { Waste Management Federal Services of Hanford, Inc. } \\ & \end{array}$


HNF-SP-1175

\author{
FLUOR DANIEL HANFORD IMPLEMENTATION PLAN \\ FOR DOE ORDER 5480.28, NATURAL PHENOMENA \\ HAZARDS MITIGATION
}

\title{
1.0 IMPLEMENTATION PLAN SUMMARY
}

\subsection{INTRODUCTION}

In 1993, the U.S. Department of Energy (DOE), Richland Operations office (RL) transmitted DOE Order 5480.28 to Westinghouse Hanford Company (WHC) for compliance. The order was reviewed. However, compliance requirements could not be determined, because "The order becomes immediately in force at the effective date of the last applicable standard." In 1993, the last of five applicable standards had not been issued. The applicable standards identified in the order and their release dates are:

DOE-STD-1020-94, Natura7 Phenomena Hazards Design and Evaluation Criteria for DOE Facilities (April 1994).

DOE-STD-1021-93, Natural Phenomena Hazards Performance Categorization Guidelines for Structures, Systems, and Components (July 1993).

DOE-STD-1022-94, Natural Phenomena Hazards Site Characterization Criteria (March 1994).

DOE-STD-1023-95, Natural Phenomena Hazards Assessment Criteria (September 1995).

DOE-STD-1024-92, Guidelines for Use of Probabilistic Seismic Hazard Curves at Department of Energy Sites (December 1992).

On October 7, 1993, WHC (Knoll 1993) notified RL that WHC would begin to assess compliance status after DOE Order 5480.28 became effective; that is, on issue of the last applicable standard. It was also recommended that the order and applicable standards be implemented as an integrated package and that implementation be performed in phases to assure cost-effective compliance.

The last applicable standard, D0E-STD-1023-95, was issued in fiscal year (FY) 1996. The RL notified WHC that the in-force date is May 15, 1996 (Kellogg 1996). However, WHC (Knoll 1996b) requested that the effective date for new SSCS be delayed unt 11 DOE approved the Hanford Site's recently developed probabilistic seismic hazards analyses (Tallman 1996b).

In 1995, DoE Order 420.1 was issued. This order contains the same natural phenomena hazards (NPH) mitigation requirements and invokes the same applicable standards as DOE Order 5480.28. This new order will supersede DOE order 5480.28 when an in-force date for the new order is established through contract revision.

On October 1, 1996, Fluor Daniel Hanford (FDH) became the Project Hanford Management Contractor (PHMC) and assumed responsibility for WHC facilities. 


\subsection{BACKGROUND}

It is the policy of the DOE to design, construct, and operate facilities so that onsite workers, the public, and the environment are protected from NPH. The NPH are unexpected acts of nature which may pose a threat or danger to workers, the public, or to the environment. Examples of NPH at the Hanford Site are earthquakes, extreme winds (hurricane and tornado), snow, flooding, volcanic ashfall, and lightning strike.

FDH is following a phased and graded approach program for compliance with DOE Order 5480.28. Activities are planned to be accomplished in four phases.

- Mobilization. Development of NPH structural design criteria for new and existing facilities, as well as a strategy and plan for implementation.

- Prioritization. Prioritization of existing facilities and issue of the implementation plan required by DOE Order 5480.28.

- Evaluation. Evaluation of NPH vulnerability of existing facilities not known to be in compliance with the Order. Assure that designs for new facilities and modifications for existing facilities are in comp Tiance.

- Upgrade. Upgrade of candidate facilities, if necessary, when justified by a risk-benefit analysis.

Activities and the level of depth, rigor, and thoroughness in accomplishing them are determined by applying a graded approach. The basis for the graded approach is the designation of facilities/structures into one of five performance categories based on safety function, mission, and cost.

The mobilization phase has been completed, but the program has been suspended starting in October 1997 because of its priority within the PHMC.

\subsection{MOBILIZATION PHASE ACCOMPLISHMENTS}

In the fall of 1993, while waiting receipt of the last DOE standard, WHC initiated a program of NPH awareness to alert staff of the pending compliance requirements of DOE Order 5480.28. Presentations were made throughout the Hanford Site to project and program personne], the WHC Operations Excellence Council, and staff from RL. Articles in the Hanford Reach discussed the potential impact of the order. The development of agreements and understandings on NPH mitigation were completed at this time. The more important of these were:

- Concurrence of RL on an interpretation of new versus existing facilities (Wise 1994, 1996).

- A proposed correlation between WHC safety class and NPH performance category (PC) (Webb and Conrads 1994).

In October 1995, the last applicable standard, DOE-STD-1023-95, was issued over the Internet, and it became evident DOE Order 5480.28 would soon be 
effective. Because the order becomes enforceable for new structures, systems, and components (SSCs) foliowing the in-force date, efforts concentrated on development of structural design and evaluation criteria to replace the site design criteria embodied in the Hanford Plant Standards, Standard Design Criteria SDC-4.1. A prerequisite for developing new site-specific design criteria is the preparation and approval by RL of updated seismic hazard analysis. This seismic hazard analysis has been completed, and approval has been granted by $R L$.

In addition to the structural design and evaluation criteria development, including NPH loads (Conrads 1996a, 1997a), the following plans, studies, and procedures were issued during the mobilization phase.

- Probabilistic NPH assessment, characterization, and criteria for the Hanford Site (Tallman 1996a, 1996b; Conrads 1996d).

- NPH detection plans for the seismic monitoring of the Hanford Site (Reidel and Moore 1996).

- A procedure for prioritization of $\mathrm{NPH}$ evaluations for existing $\mathrm{DOE}$ facilities (Conrads 1996c).

- Hanford Site emergency response plans and procedures (Wagenblast 1996a, 1996b) incorporating post-NPH requirements of DOE Order 5480.28, Section 10.d(1).

- A preliminary database output of the initial structure/facility list was included as Appendix A (Rev. 0 of the implementation plan).

The release of an implementation plan, WHC-SP-1175 Revision 0, (Conrads 1996b) on September 26, 1996, and subsequent approval by RL (Veitenheimer 1996) on November 19, 1996, marked completion of the mobilization phase. This implementation plan develops the program for the prioritization phase, as well as an overall strategy for the implementation of DOE Order 5480.28 and meeting nuclear safety requirements.

\subsection{PRIORITIZATION PHASE ACCOMPLISHMENTS}

Prioritization includes a screening to identify sites of greatest vulnerability to NPH effects and to identify existing buildings and structures of importance in terms of safety, mission, and cost. These important buildings and structures are then prioritized, based on PC, occupancy considerations, facility condition, and existing analyses. Facilities with low NPH vulnerability because of inherent ruggedness or benign site conditions are eliminated from further consideration. Estimates of the resources required to evaluate the effects of an NPH event were prepared for existing facilities of greatest importance and greatest NPH vulnerability.

The following items have been accomplished so far during the prioritization phase: 
HNF-SP-1175

- NPH seismic detection instruments were installed and became operational (Reidel 1997)

- The Post-NPH emergency response team was recruited and trained (Conrads 1997b)

- An independent peer review of the seismic hazards curves included in the Structural Design and Evaluation Criteria manual (Conrads 1997a) was completed.

Release of this revision of the implementation $\mathrm{plan}$ is being submitted to the DOE for approval within one year of the in-force date of the Order. HNF-SP-1175 suspends a 11 NPH evaluation activities beginning October 1997 until funding becomes available. The plan includes a baseline listing of existing facilities in compliance with the Order (Appendix A), facilities for which exemptions could be requested (Appendix $B$ ), and facilities needing evaluation with a prioritized list for their evaluation (Appendix $C$ ).

\subsection{SIGNIFICANT PLANNED ACTIVITIES}

No new programs are anticipated. The following new activities are associated with the phased implementation of this plan.

Evaluation Phase. In the order of prioritization and at the pace of funding availability, important buildings and structures will be evaluated to determine NPH capability in accordance with HNF-PRO-97 (Conrads 1997a).

Upgrade Phase. Existing buildings and structures shown to be vulnerable to NPH will be either upgraded or other mitigating actions will be taken to reduce risks from NPH events, depending on funding availability.

\subsection{ADDITIONAL FUNDING REQUIREMENTS}

Implementation of DOE Order 5480.28 represents additional workscope not included in current work plans. Mobilization, prioritization, and evaluation were funded through overhead accounts through FY 1997. However, formal authorization of additional funding and/or deferral of other present workscope will be necessary for completion of the prioritization, evaluation, and upgrade phases.

Estimates of additional funding and resource needs are discussed in Chapter 9.0 .

\footnotetext{
${ }^{1}$ Initiatives suspended because of lack of funding in FY98.
} 


\subsection{IMPACT ON OTHER PROGRAMS}

Impacts of NPH mitigation on other programs and plans for compensatory actions, if required, are discussed in Chapter 12.0. Except for reallocation of funding, existing programs will not be affected by implementation of DOE Order 5480.28 unti? the upgrade phase.

\subsection{ASSUMPTIONS AND CONSTRAINTS}

The implementation plan suspends all activities until funding becomes available. No other constraints are known at present.

\subsection{AREAS CURRENTLY IN FULL COMPLIANCE}

DOE Order 5480.28 contains 46 specific requirements. Compliance has been achieved for 34 . of these requirements. Five requirements do not apply to FDH.

The specific requirements of DOE Order 5480.28 are discussed in Chapter 3.0. The 326 existing facilities that are in compliance with requirements of the Order are listed in Appendix $A$.

New facilities, as defined in Section 2.4, and new modifications to existing facilities shall be designed in accordance with HNF-PRO-97 (Conrads 1997a) and shall comply with DOE Order 5480.28.

\subsection{REQUESTS FOR EXEMPTIONS, DEVIATIONS, AND WAIVERS}

Exemptions could be requested in accordance with Section 9 of DOE order 5480.28 for the 310 facilities listed in Appendix B. These are low NPH risk facilities that meet the Federal Emergency Management Agency (FEMA) exemption criteria of Executive Order (EO) 12941. The exemption process is discussed in Chapter 11.0 . 
HNF-SP-1175

This page intentionally left blank. 
HNF-SP-1175

\subsection{GENERAL INFORMATION}

\subsection{SCOPE OF THE IMPLEMENTATION PLAN}

This implementation plan encompasses all DOE new and existing facilities/SSCS on the Hanford Site under the management and control of FDH.

\subsection{CONTENT AND FORMAT OF THE PLAN}

The content and format of this plan follows the guidance provided in DOE-STD-1082-94, Preparation, Review, and Approval of Implementation Plans for Nuclear Safety Requirements. The content of the plan addresses the requirements of DOE Order 5480.28 .

The table of contents provides an overview of the organization of the plan. Terminology and section headings adhere to DOE-STD-1082-94. Executive summary, list of acronyms and terms, and reference sections are added to facilitate reading. Appendices are reserved for facility-specific baseline data.

\subsection{CONTRACTORS AND PROJECTS INVOLVED}

$\mathrm{FDH}$, as the prime contractor for the PHMC, has six subcontractors on the project management team. These contractors and the principal facility projects that they manage are as follows:

- Babcock and Wilcox Hanford Company (BWHC) manages the Facility Stabilization (STAB) project including:

- B Plant/Waste Encapsulation Storage Facility (WESF)

- Fast Flux Test Facility (FFTF)

- Fuel Fabrication Facilities (FFF)

- Plutonium Finishing Plant (PFP)

- Plutonium-Uranium Extraction Facility (PUREX)

- Duke Engineering and Services Hanford (DESH) manages the Spent Nuclear Fuels (SNF) project at K Basins (100K)

- Dyncorp Tri-Cities Services (DYN) manages the Infrastructure project including all general purpose facilities (GPF)

- Lockheed Martin Hanford Corporation (LMHC) manages the Tank Waste Remediation System (TWRS) project including:

- Tank Farms

- Numatec Hanford Corporation (NHC) has no facility management projects 
- Waste Management Federal Services of Hanford, Inc. (WMH) manages the Waste Management project including:

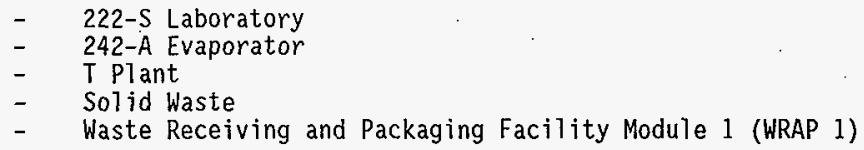

\subsection{NEW FACILITIES}

For the purpose of this plan, the following definition of a new facility/SSC was developed (Wise 1994) with the concurrence of the RL contracting officer.

A new facility/SSC is one in which conceptual design is started after the effective date of DOE Order 5480.28. Facilities/SSCS in the planning, engineering study, and preconceptual design stage on or after the effective date of DOE Order 5480.28 are new faci7ities/SSCs. Facilities/SSCs that have started conceptual design prior to the effective date of DOE Order 5480.28 are existing facilities/SSCs.

It has also been recommended (Wise 1996) that the effective date be defined as 60 days following the issue of HNF-PRO-97 (Conrads 1997a).

Al1 requirements of the order are in force for new facilities/SSCs. New facilities/SSCs and new modifications to existing facilities/SSCs shall be designed in accordance with HNF-PR0-97 (Conrads 1997a), which implements and complies with DOE Order 5480.28.

HNF-PRO-97 (Conrads 1997a) has been released and will be effective for new SSCS on October 16, 1997. Consequently, by definition, new facilitiesSSCs and modifications to existing facilities/SSCS are those whose conceptual designs begin on or after October 16, 1997.

\subsection{EXISTING FACILITIES}

Existing facilities at the Hanford Site include both nuclear and nonnuclear facilities in various stages of design, construction, operation, and decommissioning. Initial implementation activities will be directed at identifying existing buildings and structures of greatest importance and NPH vulnerability. Based on prioritization requirements of DOE Order 5480.28 , Section 11.a(5), the following definition is used in this plan.

An important existing facility is any existing, free-standing building or structure that is important in terms of safety, mission, or cost. These are designated by $P C$ as either $P C-4$ (most important), $P C-3, P C-2$, or $P C-1$ (Jeast important). 
Unimportant facilities are designated $P C-O$ and must meet all of the following screening criteria:

- No hazardous materials

- No permanent occupants

- No present or future mission

- No intent to restore or replace.

If there is insufficient information to determine whether a facility is important or unimportant, it is designated $P C-X$ unti7 such time as information becomes available on which to make an importance determination.

The "Facilities CORE" and "Richland Labs Property System" databases have been used to create a database of existing Hanford Site structures and/or facilities. This database provided the basis for completion of the mobilization phase. Further development in the scope and definition of the NPH facilities database during the prioritization phase is described in Chapter 5.0 and elsewhere in this implementation plan.

Based on the NPH facilities database, an inventory of existing buildings and structures for which FDH is responsible is shown in Table 2-1. The table identifies an inventory of facilities by performance categories for each PHMC subcontractor. Because of insufficient information, $182 \mathrm{PC}-X$ facilities could not be assigned to a subcontractor; temporarily, these facilities are assigned to the PHMC.

Table 2-1 is provided for planning purposes: The table will be updated and verified during the evaluation phase.

Tabie 2-1. Inventory of Existing Buildings and Structures.

\begin{tabular}{|l|c|c|c|c|c|c|}
\hline \multicolumn{1}{|c|}{ CONTRACTOR } & TOTALS & $P C-3$ & $P C-2$ & $P C-1$ & $P C-0$ & $P C-X$ \\
\hline BWHC & 265 & 10 & 27 & 124 & 104 & \\
\hline DESH & 41 & 2 & & 35 & 4 & \\
\hline DYN & 352 & & 7 & 248 & 97 & \\
\hline LMHC & 545 & & & & & 545 \\
\hline PHMC & 182 & & & & & 182 \\
\hline WMH & 111 & 22 & 1 & 67 & 20 & 1 \\
\hline & 1496 & 34 & 35 & 474 & 225 & 728 \\
\hline
\end{tabular}


HNF-SP-1175

This page intentionally left blank. 


\subsection{APPLICABILITY OF DOE REQUIREMENTS}

DOE Order 5480.28 contains the requirements of the DOE and are addressed in this implementation plan. The Order in turn expands on and complies with the Earthquake Hazards Reduction Act of 1977, as amended (42 U.S. Code 7701 et seq.), and Executive Order 12699 on Seismic Safety $(1-5-90)$.

In addition to the primary requirements contained in DOE Order 5480.28, several second-tier requirements and guide documents are cited in the order and in this implementation plan. These second-tier documents are discussed in Chapter 4.0 .

DOE Order 5480.28 contains 46 specific requirements. Each requirement and its status are listed in Table 3-1. The following items are identified for each requirement:

- Applicable section of DOE Order 5480.28

- Text of the requirement quoted from the Order

- Type of FDH facility affected (new or existing, etc.)

- FDH document implementing and controlling compliance

- Requirements for which compliance has been achieved

- Schedule for achieving compliance

- Exemptions, planned or requested

- Need for additional funding.

Requirements are imperative statements commanding or ordering that something be done or that a mandatory condition be achieved. In Table 3-1, each requirement is identified by a bullet, and the imperative word (usually "shall") in the statement is underlined.

\subsection{APPLICABLE REQUIREMENTS AND PROPOSED EXEMPTIONS}

No blanket exemption is being proposed for any requirement. However, exemptions could be requested from DOE for facilities listed in Appendix B. These are low NPH risk facilities that meet the FEMA exemption criteria of EO 12941. The exemption process is discussed in Chapter 11.0.

\subsection{REQUIREMENTS THAT ARE NOT APPLICABLE AND JUSTIFICATION}

Five requirements [contained in Section 10.c(1) of the Order] do not presently apply. to this implementation plan. These requirements address the NPH assessments and siting of new sites and are not in the planned or contracted scope of work for FDH. These requirements are marked "DNA" (does not apply) in Table 3-1 and are highlighted with gray shading.

During the evaluation and upgrade phases, some requirements may be found to be not applicable. Justification will be provided for any additional requirements found to be not applicable. 
HNF-SP-1175

\subsection{APPLICABLE REQUIREMENTS AND ACHIEVED COMPLIANCE}

Compliance has been achieved for 34 requirements: 29 during the mobilization phase and 5 during the prioritization phase. Requirements for which compliance has been achieved are designated in Table 3-1 with a "yes" in the fifth column and are highlighted with gray shading.

Requirements constrain the way actions shall be done. Compliance is considered achieved when governing procedures are in $\mathrm{place}$, required studies are completed, or a mandatory condition is achieved. Implementation of procedures and updating of studies may be a continuing activity while Hanford is an active site and the order remains in force. Continuing activities normally require additional funding above funding that would have been required before the order becomes in-force.

Additional funds associated with mobilization, prioritization, and evaluation are reported in this implementation plan. "A "yes" in the last column of Table 3-1 indicates that additional funding is expected to be needed or has been expended.

Additional funding associated with upgrade (retrofit) of existing facilities and the NPH mitigation of new facilities/SSCs, or new modifications to existing facilities/SSCS, will be budgeted and requested on a per-case basis by the responsible programs and will not be reported in this implementation plan.

\subsection{APPLICABLE REQUIREMENTS AND PLANNED COMPLIANCE}

Compliance has not yet been achieved for seven requirements. One requirement in Section $3 a$ of the Order concerns DOE nuclear safety policy. Implementation plans for this requirement are presented in WHC-SP-1164 (Busche 1995). Compliance with this requirement is scheduled to be completed during FY 1998.

The remaining six requirements are facility specific. Compliance with these requirements is planned during the evaluation and upgrade phases. During these phases, the requirements of DOE Order 5480.28 that are applicable to the buildings and structures under the management of FDH will be implemented. Progress in complying with facility-specific requirements is documented in appendices to this implementation plan. 
Table 3-1. Master Compliance Matrix for DOE Order 5480.28 (6 sheets).

\begin{tabular}{|c|c|c|c|c|c|c|c|}
\hline $\begin{array}{c}\text { DOE } 5480.28 \\
\text { Paragraph } \\
\end{array}$ & DOE 5480.28 Requirements & $\begin{array}{c}\text { Affected } \\
\text { Facilities }\end{array}$ & $\begin{array}{l}\text { Implement ing } \\
\text { Documents }\end{array}$ & $\begin{array}{c}\text { Compl iance } \\
\text { Achieved }\end{array}$ & $\begin{array}{c}\text { Compl iance } \\
\text { Schedule }\end{array}$ & $\begin{array}{l}\text { Waiver } \\
\text { Needed }\end{array}$ & $\begin{array}{l}\text { Additional } \\
\text { Funds } \\
\end{array}$ \\
\hline 3a Policy & $\begin{array}{l}\text { For nuclear facilities, DOE additionally } \\
\text { requires that the nuclear safety pol icy of DOE } \\
5480-23 \text { and Secretary of Energy Not ice (SEN), } \\
\text { SEN-35-91, NUCLEAR SAFETY POLICY, of } 9-9-91 \text {, } \\
\text { be met for NPH mi igation, and that cost } \\
\text { effectiveness is considered. }\end{array}$ & $\begin{array}{l}\text { All FDH } \\
\text { nuclear } \\
\text { facilities }\end{array}$ & WHC-SP-1164 & No & FY 1998 & No & Yes \\
\hline $\begin{array}{l}7 f \\
\text { Definitions } \\
\text { (Function) }\end{array}$ & $\begin{array}{l}\text { - Maintaining function after NPH occurrence } \\
\text { is required by this Order for SSCs important } \\
\text { to safety, and to minimize property losses } \\
\text { based on cost benefit considerations. }\end{array}$ & $\begin{array}{l}\text { All FDH } \\
\text { facilities }\end{array}$ & HNF-PRO-97 & No & $\begin{array}{l}\text { Appendix } \\
\text { C\&D }\end{array}$ & No & Yes \\
\hline $\begin{array}{l}\text { Exemptrons } \\
\text { Deviations } \\
4 \\
4 \\
4 \\
4\end{array}$ & 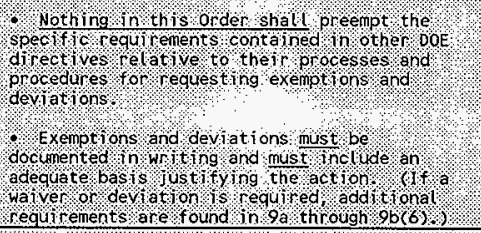 & 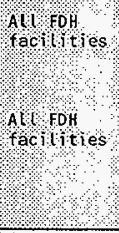 & MiN sP 1175 & & conpleted & & \\
\hline Requirenents & 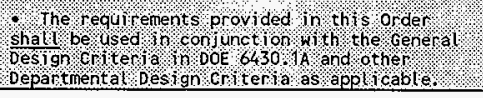 & froctroties & 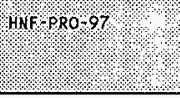 & Yes & conpleted & $\mathrm{NO}$ & \\
\hline $\begin{array}{l}\text { 10a(1) } \\
\text { Design/ } \\
\text { Evaluations } \\
\text { (General) }\end{array}$ & $\begin{array}{l}\text { Structures, systems, and components (SSCs) } \\
\text { shall be designed and constructed to wi thstand } \\
\text { the effects of NPH. }\end{array}$ & $\begin{array}{l}\text { ALl FDH } \\
\text { facilities }\end{array}$ & HNF-PRO- 97 & No & $\begin{array}{l}\text { Appendix } \\
\text { C\&D }\end{array}$ & No & Yes \\
\hline $\begin{array}{lll}+4+3 \\
+2\end{array}$ & 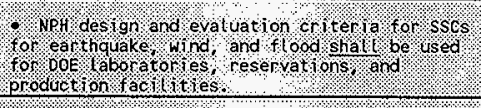 & factits & & & Conntinies & No & \\
\hline coantinod & 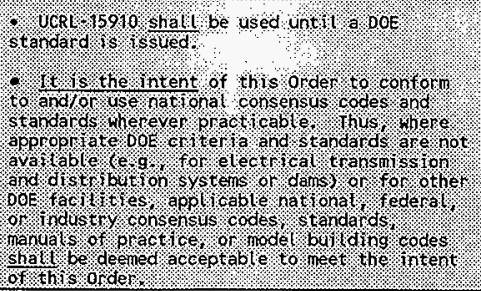 & Aldrits & 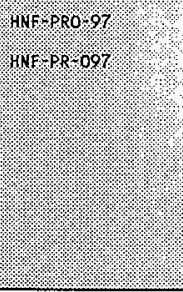 & Yes & conmol: & No & \\
\hline
\end{tabular}


Table 3-1. Master Compliance Matrix for DOE Order 5480.28 (6 sheets).

\begin{tabular}{|c|c|c|c|c|c|c|c|}
\hline $\begin{array}{c}\text { DOE } 5480.28 \\
\text { Paragraph }\end{array}$ & DOE 5480.28 Requirements & $\begin{array}{c}\text { Affected } \\
\text { Facilities }\end{array}$ & $\begin{array}{l}\text { Implementing } \\
\text { Documents }\end{array}$ & $\begin{array}{l}\text { Compliance } \\
\text { Achieved }\end{array}$ & $\begin{array}{c}\text { Compliance } \\
\text { Schedule }\end{array}$ & $\begin{array}{l}\text { Waiver } \\
\text { Needed }\end{array}$ & $\begin{array}{l}\text { Additional } \\
\text { Funds }\end{array}$ \\
\hline Toas) 2 ven & 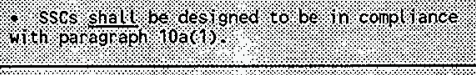 & 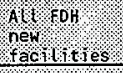 & $14 \mathrm{FPO} 97$ & yes & cont thus & $\mathrm{NO}$ & No \\
\hline 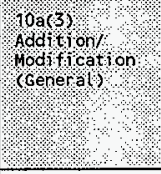 & 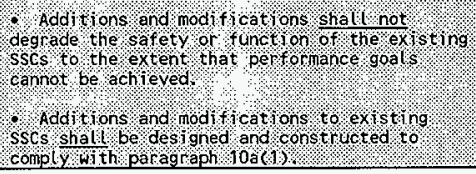 & 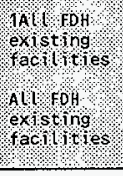 & 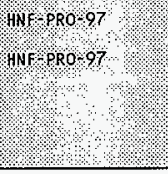 & res & 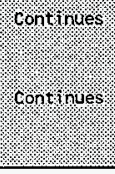 & No & yes \\
\hline $\begin{array}{l}10 a(4)(a) \\
\text { Evaluate } \\
\text { Existing } \\
\text { Facilities }\end{array}$ & $\begin{array}{l}\text { SSCs shall be reevaluated in accordance } \\
\text { with the requirements of paragraph } 10 a(1) \\
\text { under the following circumstances: } \\
\text { 1. The SSC was designed and constructed } \\
\text { without adequate NPH design and construction } \\
\text { standards. } \\
2 \text {. The function of the SSC has changed to a } \\
\text { PC with more stringent NPH requi rements such } \\
\text { as when the SSC is identified as important to } \\
\text { safety through upgrades to the facility SAR. } \\
3 \text {. There has been significant change in } \\
\text { understanding that results in an increase in } \\
\text { the site NPH hazards. } \\
4 \text {. When a SSC has been subjected to an } \\
\text { unresolved safety question and requires } \\
\text { evaluation. } \\
5 \text {. A significant physical change in the SSC } \\
\text { has been caused by an addition, a } \\
\text { modification, deterioration, or a damaging NPH } \\
\text { event. }\end{array}$ & $\begin{array}{l}\text { Alt FDH } \\
\text { existing } \\
\text { facilities }\end{array}$ & $\begin{array}{l}\text { HNF-PRO-97 } \\
\text { HNF-SP- } 1175\end{array}$ & No & $\begin{array}{l}\text { Appendix } \\
\text { C\&D }\end{array}$ & No & Yes \\
\hline $\begin{array}{l}\text { (oar }(4)(b) \\
\text { Inplement } \\
\text { WiExist ting }\end{array}$ & 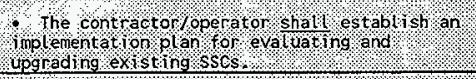 & 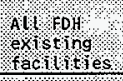 & HNF -1175 & & susponded & 10 & Yes \\
\hline 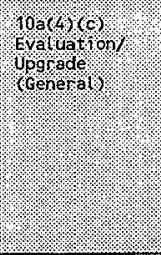 & 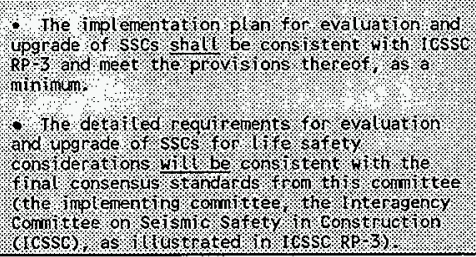 & 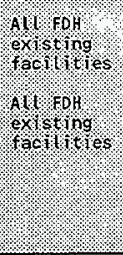 & 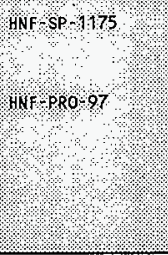 & Qes & 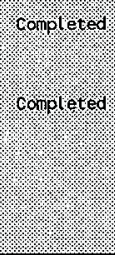 & 10 & $\begin{array}{l}1 \% 0 \\
10\end{array}$ \\
\hline
\end{tabular}


Table 3-1. Master Compliance Matrix for DOE Order 5480.28 (6 sheets).

\begin{tabular}{|c|c|c|c|c|c|c|c|}
\hline $\begin{array}{c}\text { DOE } 5480.28 \\
\text { Paragraph }\end{array}$ & DOE 5480.28 Requirements & $\begin{array}{c}\text { Affected } \\
\text { Facilities }\end{array}$ & $\begin{array}{l}\text { Impl ement ing } \\
\text { Documents }\end{array}$ & $\begin{array}{c}\text { Compl iance } \\
\text { Achieved }\end{array}$ & $\begin{array}{l}\text { Compl iance } \\
\text { Schedule }\end{array}$ & $\begin{array}{l}\text { Waiver } \\
\text { Needed }\end{array}$ & $\begin{array}{l}\text { Addit ional } \\
\text { Funds }\end{array}$ \\
\hline $\begin{array}{l}10 a(4) \\
\text { retrof } \\
\text { renerals }\end{array}$ & 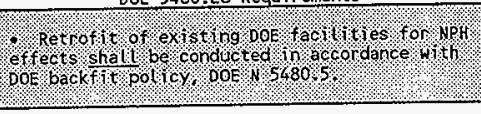 & 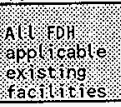 & Hin & $x_{0}=0$ & suspended & NO & \\
\hline $\begin{array}{l}10 a(5) \\
\text { Interaction } \\
\text { (General) }\end{array}$ & $\begin{array}{l}\text { Potential damage and failure of SSCS due to } \\
\text { both direct NPH effects and NPH response of } \\
\text { adjacent SSCs (interaction) shall } 1 \text { be } \\
\text { considered. }\end{array}$ & $\begin{array}{l}\text { All FDH } \\
\text { facilities }\end{array}$ & HNF-PRO-97 & TBD & $\begin{array}{l}\text { Appendix } \\
\text { CQD }\end{array}$ & No & Yes \\
\hline $\begin{array}{l}10 \mathrm{a}(6) \\
\text { Common Cause } \\
\text { (General) }\end{array}$ & $\begin{array}{l}\text { The occurrence of a NPH event, especially } \\
\text { earthquake, affects many or all SSCs in a } \\
\text { facility. Hence, it is possible to have } \\
\text { mul tiple NPH-induced failures of SSCs. These } \\
\text { common cause effects must be considered in } \\
\text { design or evaluation. }\end{array}$ & $\begin{array}{l}\text { ALL FDH } \\
\text { facilities }\end{array}$ & HNF-PRO-97 & IBD & $\begin{array}{l}\text { Appendix } \\
\text { C\&D }\end{array}$ & No & Yes \\
\hline 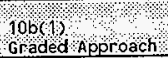 & $\begin{array}{l}\text { Paragraph } 10 a 91 \text { shal } \\
\text { graced be sapproach }\end{array}$ & Alacritities & $\mathrm{HNF} \mathrm{PRO} 97$ & $\mathrm{yes}$ & controus & 1\%o & $1 \mathrm{e}$ \\
\hline 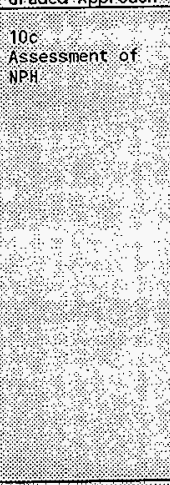 & 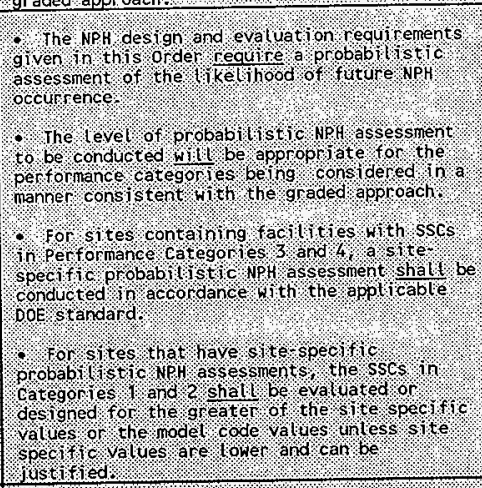 & 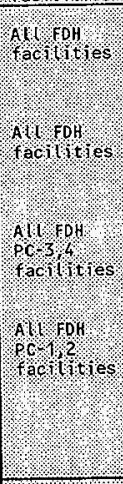 & 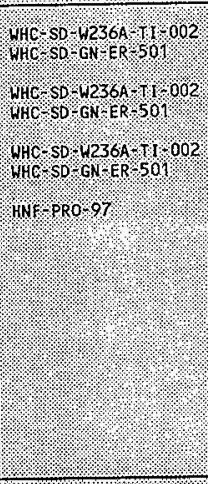 & res & 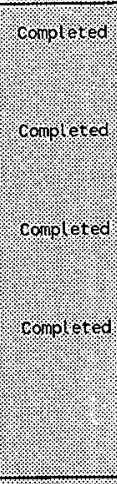 & No & 16 \\
\hline 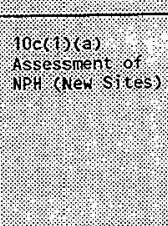 & 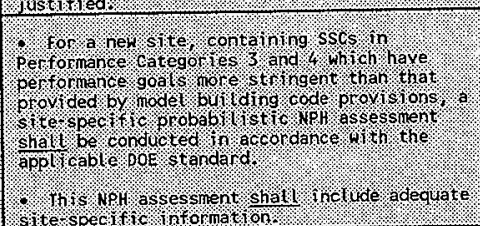 & & ONA & 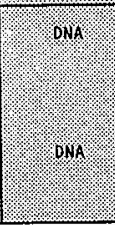 & DNA & 10 & Ho \\
\hline
\end{tabular}


Table 3-1. Master Compliance Matrix for DOE Order 5480.28 (6 sheets).

\begin{tabular}{|c|c|c|c|c|c|c|c|}
\hline $\begin{array}{l}\text { DOE } 5480.28 \\
\text { Paragraph }\end{array}$ & DOE 5480.28 Requirements & $\begin{array}{l}\text { Affected } \\
\text { Facilities }\end{array}$ & $\begin{array}{l}\text { Implement ing } \\
\text { Documents }\end{array}$ & $\begin{array}{l}\text { Compl iance } \\
\text { Achieved }\end{array}$ & $\begin{array}{c}\text { Compl iance } \\
\text { Schedule }\end{array}$ & $\begin{array}{l}\text { Waiver } \\
\text { Needed }\end{array}$ & $\begin{array}{l}\text { Additional } \\
\text { Funds }\end{array}$ \\
\hline Noc(t)hos & 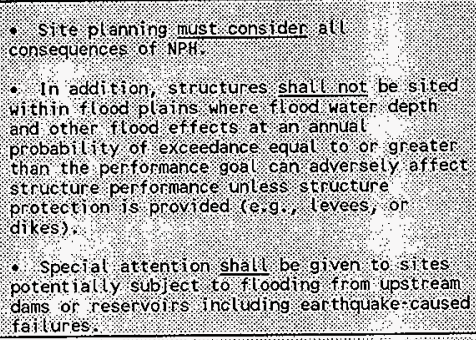 & DNA & 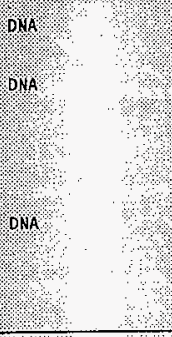 & ONA & DNA & 10. & 10 \\
\hline 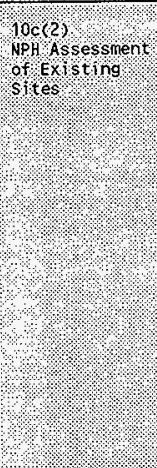 & 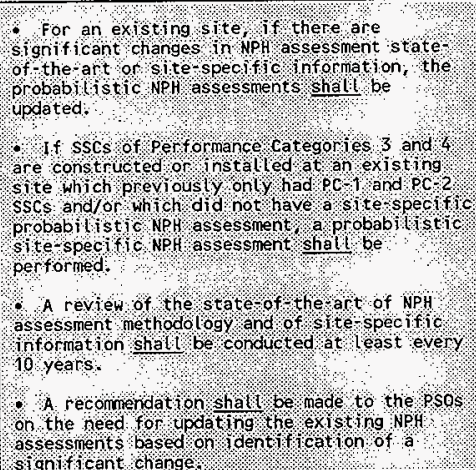 & 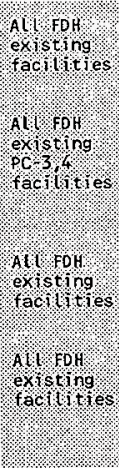 & 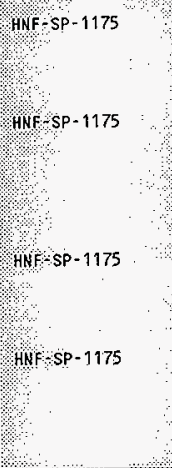 & Yes & 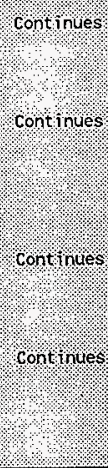 & ino & 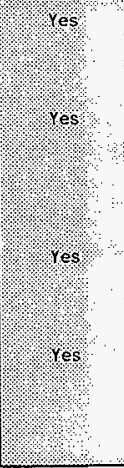 \\
\hline
\end{tabular}


Table 3-1. Master Compliance Matrix for DOE Order 5480.28 ( 6 sheets).

\begin{tabular}{|c|c|c|c|c|c|c|c|}
\hline $\begin{array}{l}\text { DOE } 5480.28 \\
\text { Paragraph }\end{array}$ & DOE 5480.28 Requirements & $\begin{array}{c}\text { Affected } \\
\text { Facilities }\end{array}$ & $\begin{array}{l}\text { Implement ing } \\
\text { Documents }\end{array}$ & $\begin{array}{l}\text { Compl iance } \\
\text { Achieved }\end{array}$ & $\begin{array}{l}\text { Compl iance } \\
\text { schedule }\end{array}$ & $\begin{array}{l}\text { Haiver } \\
\text { Needed }\end{array}$ & $\begin{array}{l}\text { Additional } \\
\text { Funds }\end{array}$ \\
\hline $\begin{array}{l}10 \mathrm{c}(3) \\
\text { sssessment } \\
\text { pet (nects) }\end{array}$ & 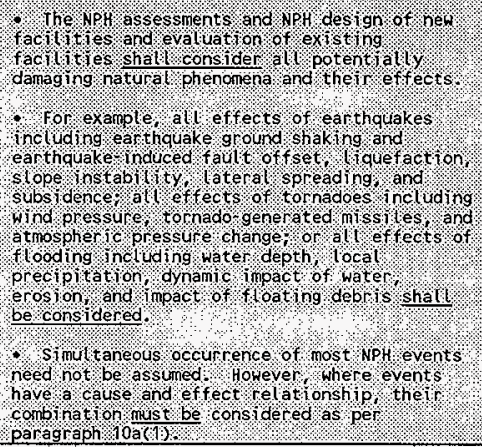 & 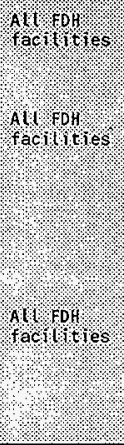 & $\begin{array}{l}4.8 \\
4 \\
4\end{array}$ & & & & es. \\
\hline $\begin{array}{l}\text { odd } \\
\text { other } \\
\text { Requirenents }\end{array}$ & 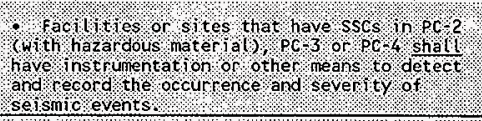 & $\begin{array}{l}\mathrm{All} \\
\mathrm{PC}, 2,3,4\end{array}$ & 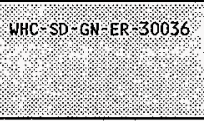 & & & & Yes \\
\hline $\begin{array}{l}10 d(2) \\
\text { other } \\
\text { Requr enents } \\
\end{array}$ & 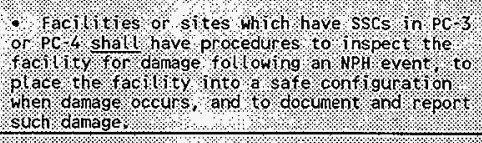 & 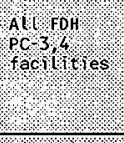 & $\begin{array}{l}\mathrm{HHC}-\mathrm{SO} \text { GNER } 503 \\
\mathrm{HHC} \text { SO-GN-ER= } 504\end{array}$ & & & 110 & Yes \\
\hline 1 Implenenting & 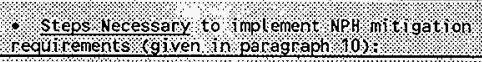 & tracilitites & $\mathrm{HiF}^{\mathrm{s} s}+117 \mathrm{~s}$ & S) & Suspende & & res \\
\hline Inolosnenting & 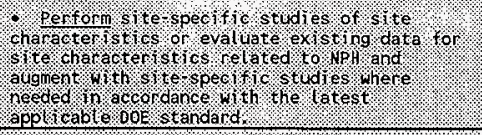 & 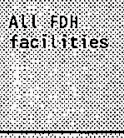 & WHC SD W W $36 \mathrm{~A}=11002$ & res & & No & 40 \\
\hline Implonenting & 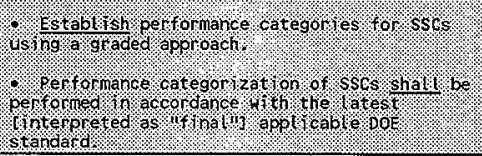 & 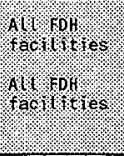 & 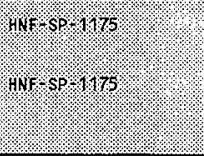 & & contingestos & 80 & res. \\
\hline
\end{tabular}


Table 3-1. Master Compliance Matrix for DOE Order 5480.28 (6 sheets).

\begin{tabular}{|c|c|c|c|c|c|c|c|}
\hline $\begin{array}{l}\text { DOE } 5480.28 \\
\text { Paragraph }\end{array}$ & DOE 5480.28 Requi rements & $\begin{array}{l}\text { Affected } \\
\text { Facilities }\end{array}$ & $\begin{array}{l}\text { Implementing } \\
\text { Documents }\end{array}$ & $\begin{array}{l}\text { Compl iance } \\
\text { Achieved }\end{array}$ & $\begin{array}{l}\text { Compl iance } \\
\text { Schedule }\end{array}$ & $\begin{array}{l}\text { Waiver } \\
\text { Needed }\end{array}$ & $\begin{array}{l}\text { Additional } \\
\text { Funds }\end{array}$ \\
\hline thasplententing & 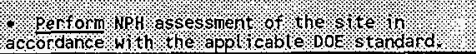 & Hacilotutes & 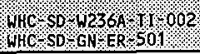 & yes & conol sed & No & 10 \\
\hline $\begin{array}{l}11 \mathrm{a}(4) \\
\text { Implementing }\end{array}$ & - Design and construct or evaluate SSCs. & $\begin{array}{l}\text { All FDH } \\
\text { facilities }\end{array}$ & HNF-PRO- 97 & No & $\begin{array}{l}\text { Appendix } \\
\text { C\&D }\end{array}$ & No & Yes \\
\hline $1195 \%$ & 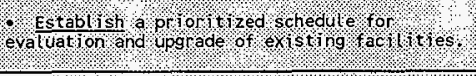 & $\begin{array}{l}\text { ACO } \\
\text { ex sting } \\
\text { factitities }\end{array}$ & HNF sp 1175 & res & suspended & 810 & No \\
\hline 10 d 1 plenenting & 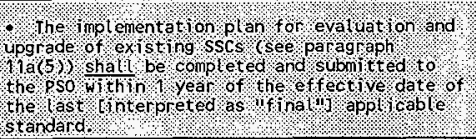 & $\begin{array}{l}\text { Alsoh } \\
\text { facting } \\
\text { farts }\end{array}$ & HN ssp 1175 & Yes & completed & ro & No \\
\hline
\end{tabular}

Busche, D. M., 1995, WHC Safety Analysis Reports and Technical Safety Requirements Upgrade Program, WhC-SP-1164, Westinghouse Hanford Company, Richland, Washington.

Conrads, T. J., 1997, Engineering Design and Evaluation (when issued), HNF-PRO-97 Rev. O, Fluor Daniel Hanford, Richland, Washington.

Reidel, S.. P. and Moore, C. J., 1996, Hanford Site Seismic Monitoring Instrumentation Plan, WHC-SD-GN-ER-30036 Rev. 0, Westinghouse Hanford Company,

I Richland, Washington.

Tal Íman, A. M., 1996, Naturat Phenomena Hazards, Hanford Site, South-Central Washington, WHC-SD-GN-ER-501 Rev. O, Westinghouse Hanford Company, Richland, Washington.

Tal Iman, A. M.., 1996, Probabilistic Seismic Hazard Analyses, DOE Hanford Site, Washington, WHC-SD-W236A-TI-002 Rev. 1, West inghouse Hanford Company,

Richland, Washington.

Wagenblast, G. R., 1996, Hanford Site Post-NPH Building Inspection Plan, WHC-SD-GN-ER-504, ICF Kaiser Hanford Company, Richland, Washington.

Wagenblast, G. R., 1996b, Procedure for Post-NPH Inspection of BuildingS, WHC-SD-GN-ER-503, ICF Kaiser Hanford Company, Richland, Washington.

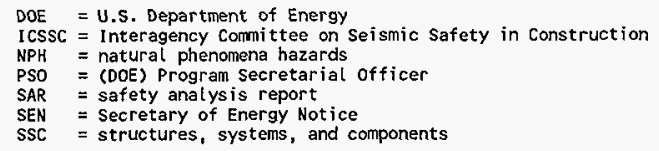




\subsection{IMPLEMENTATION GUIDES AND TECHNICAL STANDARDS}

\subsection{DOE IMPLEMENTATION GUIDES AND STANDARDS}

DOE Order 5480.28 explicitly invokes certain second-tier documents as requirements. These documents with referenced sections from DOE Order 5480.28 follow.

SEN-35-91, Nuclear Safety Policy (1991). This policy document establishes DOE intent in the areas of management, technical competency, safety goals, oversight and self-assessment, and safety culture. Specific implementing requirements are contained in DOE Orders and Directives. (Reference Section 3.a.)

DOE Order 5480.23, Nuclear Safety Analysis Reports (1992). This Order establishes requirements for safety anaiyses that evaluate the adequacy of the safety bases of facilities. Implementation of this order is addressed in WHC-SP-1164, Busche,D.M., WHC Safety Analysis Reports and Technical Safety Requirements Upgrade Program (September 1995). (Reference Section 3.a.)

DOE Order 6430.1A, Genera7 Design Criteria (1989). This order established codes, Toads, and special design requirements for nonreactor DOE facilities. Implementation of the order is achieved through the use of existing FDH procedures and the review of new and revised FDH procedures. (Reference Section 10.0.)

UCRL-15910, Design and Evaluation Guidelines for DOE Facilities Subjected to Natural Phenomena Hazards (1990). This is now superseded by DOE-STD-1020-94. (Reference Section 10.a(1).)

ICSSC RP-3, Guidelines for Identification/Mitigation of Seismically Hazardous Existing Federal Buildings (1989). Development of RP-3 was sponsored by the FEMA. It contains "rollup" fields for a national database that monitors compliance with Executive Order 12699 on seismic safety for new construction. This implementation $\mathrm{plan}$ includes the rollup fields and describes a Hanford Site database that will be compatible with FEMA. (Reference Section 10.a(4)(c).)

DOE Notice 5480.5, Imposition of Proposed Nuclear Safety Requirements (1992). This notice establishes a cost-effective methodology for the backfit (upgrade) of existing DOE facilities found to be out of compliance with current requirements. This implementation $\mathrm{plan}$ addresses this order in the upgrade phase. (Reference Section 10.a(4)(d).)

DOE standards normally describe on ly acceptable methods and processes but do not estabijsh requirements. All or part of the provisions in a standard can become requirements if a DOE requirements document explicitly states they are requirements or a commitment is made to meet a standard. Attachment 1 to DOE Order 5480.28 invokes five applicable technical standards as mandatory.

DOE-STD-1020-94, Natural Phenomena Hazards Design and Evaluation Criteria for DOE Facilities (1994). This standard gives design and evaluation criteria for NPH affects as guidance in implementing the NPH mitigation requirements of DOE Order 5480.28 . The standard also provides acceptable 
methodology for determining the structural capability of SSCs subjected to seismic, wind, and flood hazards. The criteria apply to the design of new facilities and to the evaluation of existing facilities and may be used for the modification and upgrade of existing facilities.

DOE-STD-1021-93, Natural Phenomena Hazards Performance Categorization Guidelines for Structures, Systems, and Components (1993). This standard provides guidelines for selecting PCs and recommends systematic procedures for consistent application of guidelines and implementation of a graded approach.

DOE-STD-1022-94, Natura7 Phenomena Hazards Site Characterization Criteria (1994). This standard provides general and detailed requirements and methodology for site characterization leading to the acquisition of needed site-specific NPH information.

DOE-STD-1023-95, Natural Phenomena Hazards Assessment Criteria (1995). This standard provides general and detailed criteria for NPH assessments, for the construction of hazard curves, and for establishing adequate design basis load levels.

D0E-STD-1024-92, Guidelines for Use of Probabilistic Seismic Hazard Curves at Department of Energy Sites (1992). This standard provides guidance in the lise of the seismic hazard curves developed by the Lawrence Livermore National Laboratory and the Electric Power Research Institute. Experience has shown that application of these methodologies can yield significantly different results. In response to this issue, a Seismic Working Group has been formed to coordinate the application of these methodologies within DOE in a consistent manner. The position developed by the group and contained in this standard is intended for immediate use in developing seismic hazard estimates at DOE sites for the evaluation of new and existing nuclear and non-nuclear DOE facilities.

In addition, guidance on the format and minimum content of implementation plans is contained in DOE-STD-1082-94, Preparation, Review, and Approval of Implementation Plans for Nuclear Safety Requirements (1994). This is a general standard for the preparation, review, and approval of implementation plans and contains expectations common to all implementation plans.

\subsection{FDH IMPLEMENTATION GUIDES. AND STANDARDS}

This implementation plan is the main FDH control document that specifically addresses compliance with DOE Order 5480.28. The plan is supported chronologically by the following FDH studies, plans, and criteria.

Webb and Conrads (1994), Proposed Correlation of DOE Safety Classes, Performance Categories, and Design Requirements, WHC-SD-GN-RD-30011 Rev. 0. This position paper expands on the methodology of DOE-STD-1021 and provides background on the development of the correlation of PCs to the existing process of SSC safety classification used by WHC.

Reidel and Moore (1996), Hanford Site Seismic Monitoring Instrumentation Plan, WHC-SD-GN-ER-30036 Rev. 0. This document describes the WHC compliance plan for NPH detection requirements contained in DOE order 5480.28, Section 10.d(1). 
Tallman (1996b), Probabilistic Seismic Hazard Analyses, DOE Hanford Site, Washington, WHC-SD-W236A-TI-002 Rev. 1. This document is a compilation of the probabilistic, site-specific seismic characterization data, and seismic design loads prepared under contract by Geometrix.

Conrads (1996d), Volcanic Ashfall Loads for the Hanford Site, WHC-SD-GN-ER-30038 Rev. 0 . This document presents risk-reduction factors prepared under contract by EQE International.

Conrads (1996a), Guidelines for Assessing the Seismic Adequacy of Existing Performance Category Equipment at the Hanford Site, WHC-SD-GN-DGS-30006 Rev. 1. This revision updates criteria for new NPH design loads.

Tallman (1996a), Natural Phenomena Hazards, Hanford Site, South-Central Washington, WHC-SD-GN-TI-501 Rev. 0 . This revision presents the latest probabilistic, site-specific NPH seismic, wind, flood, ashfall, and lightening design loads.

Conrads (1996c), Procedure for Prioritization for Natural Phenomena Hazards Evaluations of Existing DOE Facilities, WHC-SD-GN-ER-30037 Rev. 0. This procedure complies with and implements Sections $10.2(4) b$ and $11.2(5)$ of DOE Order 5480.28 .

Wagenblast (1996a), Hanford Site Post-NPH Building Inspection Plan, WHC-SD-GN-ER-504, (September 12, 1996). This plan establishes consistent post-NPH building inspection procedures and defines a procedure for prioritization of buildings for inspection.

Wagenblast (1996b), Procedure for Post-NPH Inspection of Buildings, WHC-SD-GN-ER-503. This procedure provides guidelines and posting requirements for performing a post-NPH safety inspection of buildings throughout the Hanford Site.

Conrads (1997a), Engineering Design and Evaluation, HNF-PRO-97 Rev 0. This criteria applies to the design of new facilities, modification of existing facilities, and NPH evaluation of existing facilities. The criteria implements DOE-STD-1020 and replaces Hanford Plant Standard SDC 4.1 and GC-LOAD-01 (Rueben 1996).

Reidel, S. P., A. C. Rohay, and D. C. Hartshorn, 1997a, Hanford Strong Motion Acce] erometer Network: A Summary of the First Month of Operation, HNF-SD-GN-ER-508. This document describes the design, construction, and operation of a strong motion accelerometer system at the Hanford Site. 
HNF-SP-1175

This page intentionally left blank. 


\subsection{COMPLIANCE BASELINE}

A baseline is an agreed-to condition. A compliance baseline identifies the degree of compliance with each requirement at a point in time. For credibility, baselines should be documented and should reference those documents that justify compliance.

\subsection{ESTABLISH THE COMPLIANCE BASELINE}

A seven-step methodology is used to establish the compliance baseline. Steps (a) through (d) were completed during the mobilization phase. Steps (e) through $(g)$ were completed during the prioritization phase.

(a) Establish the NPH Requirement Compliance Baseline. The applicable requirements in DOE Order 5480.28 are shown in Table 3-1. The status of compliance and the report documenting compliance are also identified in the table.

(b) Specify the Work Control Documents. To assure compliance, work is controlled with plans, procedures, and completion reports. These work control documents are identified in Table 3-1. This $p l a n$ is the primary work control document implementing DOE Order 5480.28 and follows the guidance provided in DOE-STD-1082. The purpose and content of second-tier work control documents are described in Section 4.2 .

(c) Identify Facility-Specific Requirements. Compliance with sitewide procedural requirements is achieved without facility-specific information. This implementation plan is an example of compliance with a procedure requirement in DOE Order 5480.28 , Section 11.d(4). As discussed in Section 3.4 and identified in Table 3-1, other requirements are facility specific, and compliance is achieved only after data about a particular facility are obtained. Table 3-1 categorizes each requirement as either sitewide or facilityspecific.

(d) Analyze the Facility-Specific Requirements. Based on the facilityspecific requirements, an analysis of the data needed is shown in Table 5-1. Information should address the requirements of the DOE Order and, also, be compatible with FEMA reporting guidelines. Additional data not specially required by the order or FEMA are needed to control the collection of or support the needed information. The table identifies required fields, the requirement for the data, and primary source of the needed data.

(e) Develop a Facility/SSC NPH Compliance Database. A computerized database was developed and included in Rev. 0 of the implementation plan. This database has been augmented to include records in various predecessor Hanford databases. The database is structured to include the required fields shown in Table 5-1. Data are stored and accessed as required to support the prioritization phase, the evaluation phase, and the upgrade phase. 
(f) Prioritize Facilities for NPH Vulnerability. Prioritization criteria and a NPH Facility Prioritization Worksheet are described in Section 8.2. Program managers and/or landiords have completed and approved worksheets for their facilities. The facility/SSC NPH comp 7 iance database was checked against and updated based on data in the returned worksheets. The database was then sorted to identify existing buildings and structures that require NPH evaluation. The process of sorting and prioritizing the database is described in Section 8.3. A prioritized schedule for the evaluations is shown in Appendix $C$.

(g) Establish the Facilities NPH Compliance Baseline. The facilities compliance baseline summarizes the facilities database. This baseline identifies the status of compliance of individual facilities with DOE Order 5480.28 and with Executive Orders 12699 and 12941. This baseline is a reportable subset of key or "baseline" fields from the compliance database. Basel ine fields are indicated by an "*" in Table 5-1. The baseline is reported in the appendices and described in the following section.

\subsection{REPORT THE COMPLIANCE BASELINE}

The NPH Compliance Baseline consists of two parts: The requirements baseline (Table 3-1, Master Compliance Matrix for DOE Order. 5480.28) and the facilities NPH compliance baseline (reported in four appendices to this implementation $p 1 a n)$. Every new and existing facility for which FDH is responsible is included in the facilities compliance baseline.

Appendix A. Compliance Baseline for New and Existing Buildings and Structures in Compliance with DOE Order 5480.28

Appendix $A$ identifies those facilities in compliance with requirements of the order.

At the end of the prioritization phase, Appendix A identifies only unimportant and inherentiy rugged facilities that are eliminated from further consideration by Section 11.a(5) of the Order. As discussed in Section 8.2 of this implementation plan, unimportant facilities are identified as $\mathrm{PC}-0$, and inherently rugged facilities are identified by a prioritization score of 5 or less.

A conceptual design initiated 60 days following issuance of HNF-PRO-97 defines a new SSC or new modification and shall comply with requirements of the order. As identified, new facilities and new modifications are added to Appendix $A$.

As NPH mitigation progresses and existing facilities are qualified for compliance, the facilities are moved to Appendix $A$ from Appendices $B, C$ and $D$. At end of the upgrade phase all facilities will be listed in Appendix $A$, the other appendices will be empty, and NPH mitigation will be complete. 
Appendix B. Compliance Baseline for Existing Buildings and Structures where an Exemption or Deviation is being Requested

Exemptions are authorizations to exclude something from requirements. Deviations are authorizations to depart from particular requirements, and comply in a more appropriate, specified manner. Deviations are usually granted before-the-fact; when granted after-the-fact, they are often referred to as waivers. Exemptions and deviations are requested in accordance with Section 9 of DOE Order 5480.28 , and must be approved in writing by DOE.

Appendix B contains only PC-1 facilities that are exempt by FEMA criteria. Generally, this group has low priority scores and, consequently, low evaluation priority. A request for exemptions for these facilities could be submitted to DOE. The exemption process is discussed in Chapter 11.0.

At the end of the prioritization phase, no other exemptions or deviations are being requested. During the evaluation and upgrade phases, conditions may be discovered that warrant additional requests for exemptions and/or deviations.

Until a request is acted on, a "hold" is put on that facility. If DOE approves the request, the facility is considered in compliance with the Order and is moved into Appendix $A$ of the Baseline. If DOE disapproves the request, the facility is scheduled for evaluation and added to Appendix $C$.

Appendix C. Compliance Baseline and Prioritized Schedule for Existing Buildings and Structures Requiring NPH Evaluation

At the end of the prioritization phase, this appendix will list all existing buildings and structures not listed in Appendices A or B. These facilities are ranked by their priority scores, and NPH evaluations are scheduled in the order of priority scores.

The process for sorting the Compliance Baseline into Appendices $A, B$, and $C$ and developing a prioritized schedule is described in Section 8.3 . Evaluation commitments and processes are described in Section 6.3.

Appendix $C$ contains those facilities where compliance has not been determined. That is, there is insufficient information in the compliance database to determine if these facilities comply or do not comply with requirements of the order. The primary causes of this indeterminacy are as follows:

(1) Facility records exist in the database for which there is no matching prioritization worksheet. These records were in the various predecessor Hanford Site databases that were compiled to form the present NPH Compliance Database. The unconfirmed records include such things as abandoned or demolished buildings, aborted projects, duplicate entries, items transferred to other contractors, and facilities for which the responsible contractor has not submitted a prioritization worksheet. 
Data may not be available to complete the prioritization worksheet. For example the age of the facility, the code used, or the NPH analyses may not be available to the field.

Finally, although guidelines are provided, prioritization is a screening process and several of the worksheet ratings are subjective. Importance to program, number of visitors, facility condition and existing NPH analysis are examples of subjective data. Under these circumstances, a consciences evaluator will err on the side of conservatism.

The NPH evaluation removes uncertainties from the database. The result of NPH evaluation is a determination that (a) a building or structure is presently in compliance with DOE Order 5480.28, (b) an exemption or deviation is justified, (c) the database record is redundant, or (d) upgrade may be necessary to achieve compliance. Each evaluation is documented in an evaluation report. When this report is approved, the facility listing is moved from Appendix $C$ into Appendix $A, B$ or $D$ as appropriate; or if redundant, removed from the baseline.

Appendix D. Compliance Baseline for Existing Buildings and Structures that are Candidates for Upgrade

Appendix $D$ identifies the high risk facilities where an upgrade may be, or is, required. These are facilities not known to be in compliance, as well as facilities known not to comply with requirements of the order. At the end of the prioritization phase, there are no facilities known to be out of compliance with the Order and Appendix $D$ is empty.

\subsection{MANAGE THE COMPLIANCE BASELINE}

The compliance baseline (reported in Table 3-1 and Appendices A, B, C, and $D)$ changes over time. The process of managing and updating the baseline is shown in Figure 5-1. The figure shows decisions and the flow of data through the four implementation phases, how the four facility baselines evolve from this data, and the relationship of the requirements baseline to the facility baseline.

As with any baseline, changes are carefully controlled. Table 3-1, the requirements baseline, is estabilished at the end of the mobilization phase. The facility baseline contained in Appendices A, B, C and D is first reported at the end of the prioritization phase. Thereafter, changes to the base? ine are made only when updated data are received in the following forms:

Prioritization Worksheets (PW)

Evaluation Reports (ER)

Upgrade Reports (UR)

Letters from DOE 
Table 5-1. Facilities Natural Phenomena Hazard Compliance Database Structure. (2 sheets)

\begin{tabular}{|c|c|c|c|c|c|c|}
\hline & \multirow{2}{*}{$\begin{array}{l}\text { REQUIRED DATABASE FIELDS } \\
\text { (* indicates Basel ine Field) }\end{array}$} & \multirow{2}{*}{ ENTER } & \multicolumn{3}{|c|}{ FIELD REQUIRED BY } & \multirow{2}{*}{$\begin{array}{l}\text { SOURCE OF } \\
\text { DATA }\end{array}$} \\
\hline & & & FEMA & 5480.28 & Other & \\
\hline $\begin{array}{l}\text { A } \\
\text { A1 } \\
\text { A2 } \\
\text { A3 } \\
\text { A4 } \\
\text { A5 }\end{array}$ & $\begin{array}{l}\text { CHANGE CONTROL } \\
\text { Prioritization Worksheet (PW) } \\
\text { Evaluation Report (ER) } \\
\text { Latest Upgrade Report (UR) } \\
\text { Other verified data received } \\
\text { Describe other data }\end{array}$ & $\begin{array}{l}\text { Date } \\
\text { Date } \\
\text { Date } \\
\text { Date } \\
\text { Code }\end{array}$ & & & $\begin{array}{l}\text { Accountability } \\
\text { Accountability } \\
\text { Accountability } \\
\text { Accountabil ity } \\
\text { Accountabil ity }\end{array}$ & $\begin{array}{lll}\text { PW } & & \\
& \text { ER } & \\
& & \text { UR }\end{array}$ \\
\hline $\begin{array}{l}\text { B } \\
\text { B1 } \\
\text { B2 } \\
\text { B3 } \\
\text { B4 } \\
\end{array}$ & $\begin{array}{l}\text { SITE IDENTIFICATION } \\
\text { Agency: DOE } \\
\text { Site name: Hanford } \\
\text { State: WA } \\
\text { County: Benton }\end{array}$ & $\begin{array}{l}\text { DOE } \\
\text { Text } \\
\text { WA } \\
\text { Text }\end{array}$ & $\begin{array}{l}\# 1 A \\
\# 2 A \\
\# 2 B\end{array}$ & $\sec 10 c(2)$ & Prioritization & $\begin{array}{l}\text { Constant } \\
\text { Constant } \\
\text { Constant } \\
\text { Constant } \\
\end{array}$ \\
\hline $\begin{array}{l}c \\
{ }_{*} \mathrm{C} 1 \\
{ }^{\star} \mathrm{C} 2 \\
\mathrm{C} 3\end{array}$ & $\begin{array}{l}\text { FACILITY IDENTIFICATION } \\
\text { I dent ifier } \\
\text { Name of Facility } \\
\text { Location (Area \& Address) }\end{array}$ & $\begin{array}{l}\text { Text } \\
\text { Text } \\
\text { Code }\end{array}$ & $\# 1 B$ & & $\begin{array}{l}\text { Prioritization } \\
\text { Prioritization } \\
\text { Prioritization }\end{array}$ & $\begin{array}{l}\text { PW, ER } \\
\text { PW, ER } \\
\text { PW, ER }\end{array}$ \\
\hline $\begin{array}{c}D \\
* 01 \\
02\end{array}$ & $\begin{array}{l}\text { OCCUPANT IDENT IFICATION } \\
\text { Contractor responsible } \\
\text { Manager of Facility }\end{array}$ & $\begin{array}{l}\text { Code } \\
\text { Text }\end{array}$ & & & $\begin{array}{l}\text { Funds Approval } \\
\text { Entry Approval }\end{array}$ & $\begin{array}{l}\text { PW, ER } \\
\text { PW, ER }\end{array}$ \\
\hline $\begin{array}{l}\text { E } \\
\text { E1 } \\
\text { E2 } \\
\text { E3 } \\
\text { E4 } \\
\text { E5 } \\
\text { E6 } \\
\text { E7 }\end{array}$ & $\begin{array}{l}\text { FACILITY CLASSIFICATION } \\
\text { New or Existing? } \\
\text { Owned or Leased? } \\
\text { Type (bidg, struct, etc) } \\
\text { Occupancy Class: GSA category } \\
\text { Essential or Other? } \\
\text { Historic or Non-Historic? } \\
\text { Status (active, surplus, etc) }\end{array}$ & $\begin{array}{l}N / E \\
O / L \\
\text { Code } \\
\text { Code } \\
\text { E/O } \\
H / N \\
\text { Code }\end{array}$ & $\begin{array}{l}\text { Yes } \\
\text { Yes } \\
\# 6 \\
\# 7 \\
\# 8\end{array}$ & $\begin{array}{l}\sec 10 \\
\sec 7 r\end{array}$ & $\begin{array}{l}\text { EO } 12699,12941 \\
\text { EO } 12699,12941 \\
\text { Prioritization }\end{array}$ & $\begin{array}{r}\text { ER } \\
\text { ER } \\
\text { ER } \\
\text { ER } \\
\text { ER } \\
\text { ER } \\
\text { PW, ER } \\
\end{array}$ \\
\hline $\begin{array}{l}F \\
F 1 \\
F 2 \\
* F 3 \\
F 4 \\
F 5 \\
F 6 \\
F 7 \\
F 8 \\
F 9 \\
10 \\
11\end{array}$ & $\begin{array}{l}\text { SAFETY IMPORTANCE } \\
\text { Day shift } \\
\text { Visitors } \\
\text { Max occupancy (any } 2 \text { hours) } \\
\text { Seismic hazard } \\
\text { FEMA high risk code } \\
\text { Hazardous materials } \\
\text { SAR document number } \\
\text { Hazard category } \\
\text { Hazard class } \\
\text { Safety class/significant } \\
\text { obsolete WHC safety class }\end{array}$ & $\begin{array}{l}\text { No. } \\
\text { No. } \\
\text { No. } \\
\text { No. } \\
\text { Code } \\
\text { Text } \\
\text { No. } \\
\text { No. } \\
\text { Code } \\
\text { SC/ss } \\
\text { No. }\end{array}$ & $\begin{array}{l}\text { Ex } 1 \\
\# 3 \\
\# 12\end{array}$ & $\begin{array}{l}\text { Sec } 10 b \\
\text { Sec } 10 a(4) \\
\text { Sec } 10 a(4) \\
\text { sec } 10 c(3) \\
\text { Sec } 3 a \\
\text { Sec } 3 a \\
\text { Sec } 3 a\end{array}$ & $\begin{array}{l}\text { Prioritization } \\
\text { Prioritization } \\
\text { Prioritization } \\
\text { Prioritization } \\
\text { Order } 5480.23 \\
\text { Order } 5481.18 \\
\text { Prioritization } \\
\text { Prioritization }\end{array}$ & $\begin{array}{l}\text { PW, ER } \\
\text { PW, ER } \\
\text { PW, ER } \\
\text { WHC-SD-GN- } \\
\text { ER-S01 } \\
\text { Appendix D } \\
\text { PW, ER } \\
\text { PW, ER } \\
\text { PW, ER } \\
\text { ER } \\
\text { ER } \\
\text { PW, ER }\end{array}$ \\
\hline $\begin{array}{r}G \\
\star G 1 \\
G 2 \\
* G 3 \\
G 4 \\
G 5\end{array}$ & $\begin{array}{l}\text { MISSION IMPORTANCE } \\
\text { Project or Program } \\
\text { Importance to program } \\
\text { Year surplus: Transfer to BHI } \\
\text { Other affected programs } \\
\text { Restore if damaged? }\end{array}$ & $\begin{array}{l}\text { Code } \\
\text { Code } \\
\text { Year } \\
\text { Code } \\
\text { Y/N }\end{array}$ & EX 9 & $\sec 10 \mathrm{~b}$ & $\begin{array}{l}\text { Prioritization } \\
\text { Prioritization } \\
\text { Prioritization } \\
\text { Prioritization } \\
\text { Prioritization }\end{array}$ & $\begin{array}{l}\text { PW, ER } \\
\text { PW, ER } \\
P W, E R \\
\text { EW, ER } \\
\end{array}$ \\
\hline $\begin{array}{c}H \\
* H 1 \\
H 2 \\
H 3 \\
H 4 \\
H 5 \\
H 6\end{array}$ & $\begin{array}{l}\text { STRUCTURAL DESCRIPTION } \\
\text { Area (covered floorspace) } \\
\text { Number buildings, or Top Bldg } \\
\text { Number of stories. } \\
\text { Soil type } \\
\text { Foundation type } \\
\text { Model building ATC-21 type }\end{array}$ & $\begin{array}{l}\mathrm{m}^{\wedge} 2 \\
\text { Code } \\
\text { No. } \\
\text { Code } \\
\text { Code } \\
\text { Code }\end{array}$ & $\begin{array}{l}\# 4 A \\
\# 4 B \\
\# 11 \\
\# 14 \\
\# 15 \\
\# 10\end{array}$ & & $\begin{array}{l}\text { Prioritization } \\
\text { Prioritization }\end{array}$ & $\begin{array}{r}\text { PW, ER } \\
\text { ER } \\
E R \\
E R \\
\text { ER } \\
\text { ER } \\
\text { PW, ER } \\
\end{array}$ \\
\hline $\begin{array}{r}1 \\
* I 1 \\
12 \\
13 \\
14 \\
15 \\
16 \\
17 \\
\text { * } 18\end{array}$ & $\begin{array}{l}\text { FACILIIY CONDITION } \\
\text { Year construction complete } \\
\text { ATC-21 score } \\
\text { structural condition } \\
\text { Nonstructural, not checked } \\
\text { Geologic/site hazard passable } \\
\text { Adjacency ( } 3 / 1) \text { condition } \\
\text { structural accidents } \\
\text { Facility condition rating }\end{array}$ & $\begin{array}{l}\text { Year } \\
\text { No. } \\
\text { Code } \\
\text { NCN } \\
\text { PS } \\
\text { Code } \\
\text { Code } \\
\text { Code }\end{array}$ & $\begin{array}{l}\# 9 \\
\# 17 \mathrm{~A} \\
\# 17 \mathrm{~B} \\
\# 17 \mathrm{C} \\
\# 170\end{array}$ & $\sec 10 c(3)$ & $\begin{array}{l}\text { Prioritization } \\
\text { Prioritization } \\
\text { Prioritization } \\
\text { Prioritization } \\
\text { Prioritization }\end{array}$ & $\begin{array}{l}\text { PW, ER } \\
\text { PW, ER } \\
E R \\
\text { Constant } \\
\text { Constant } \\
\text { ER } \\
\text { PW, ER. } \\
\text { PW, ER . }\end{array}$ \\
\hline
\end{tabular}


Table 5-1. Facilities Natural Phenomena Hazard

Compliance Database Structure. (2 sheets)

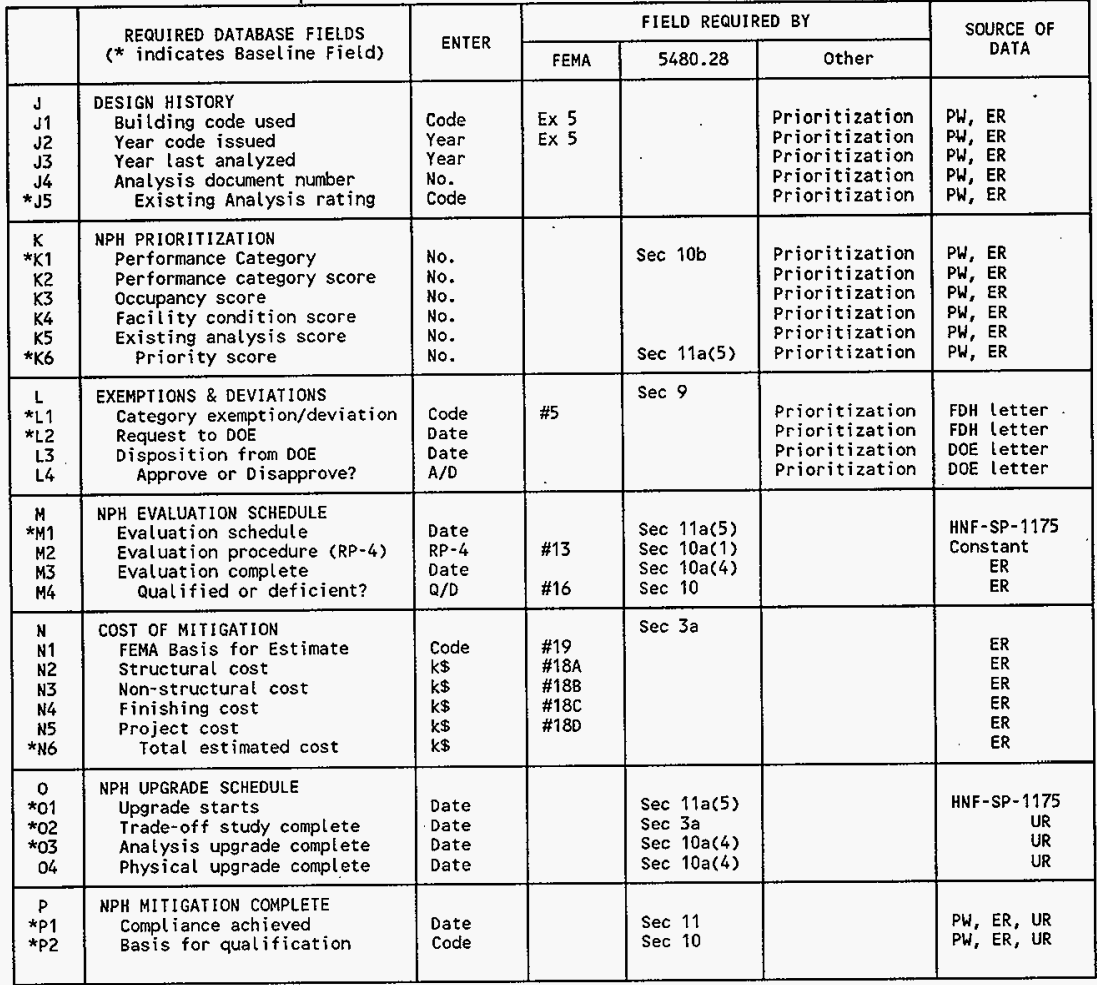




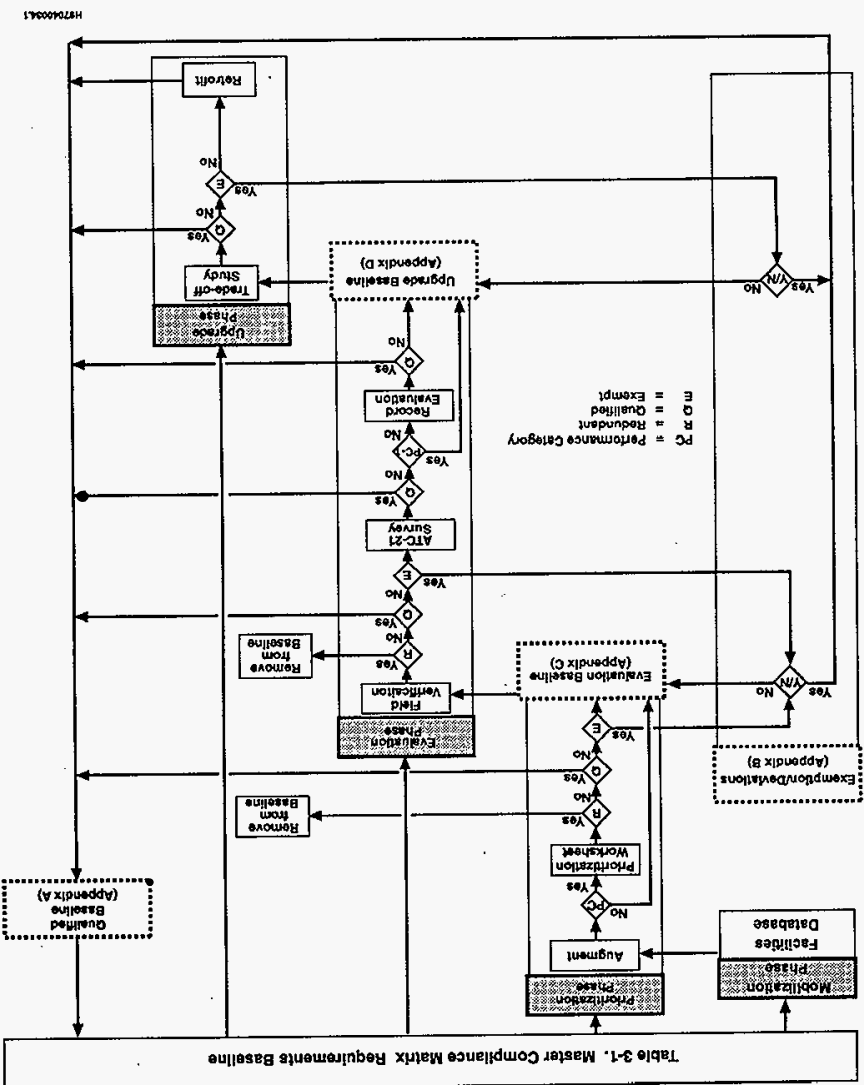

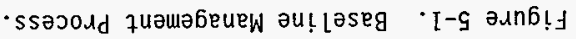


HNF-SP-1175

This page intentionaliy left blank. 
HNF-SP-1175

\subsection{COMMITMENTS}

Commitments are the additional activities planned to meet requirements. The combination of baseline activities and commitments is a list of all activities necessary and sufficient to achieve full compliance.

The level of detail provided allows clear interpretation of the intent of the commitment but does not include daily activities reflected in facilityspecific procedures. Milestones and schedules associated with commitments are proposed in Chapter 10.0. The commitment tracking process is discussed in Chapter 13.0 .

\subsection{MOBILIZATION PHASE COMMITMENTS}

The seven-step methodology used to establish the compliance baseline is described in Section 5.1. The first four steps [(a) through (d)] were completed during the mobilization phase as reported in Revision 0 of the implementation plan.

\subsection{PRIORITIZATION PHASE COMMITMENTS}

Two steps [(e) and (g)] of the methodology described in Section 5.1 were completed during the prioritization phase. Development of the Facilities NPH Compliance Database is complete [task (e)] and is sorted to provide the prioritized schedule for vulnerable facilities requiring NPH evaluation found in Appendix $C$ [task ( $f$ ) and milestone NPH-P2] and the Facilities NPH Compliance Baseline contained in the four appendices to this plan [task (g) and milestone NPH-P3]. Task (f) is not complete in that some facility worksheets have not completed which precludes defining a unique priority.

Additional activities planned and accomplished during the prioritization phase are defined by the "other requirements" of DOE Order 5480.28:

Section 10.d(1) Install NPH Detection Instrumentation. Seismic monitoring instrumentation has been procured, installed, and was briefly operational in accordance with WHC-SD-GN-ER-30036 (Reidel and Moore 1996.). Completion of this activity [task (h) and milestone NPH-P4] is documented in a letter report (Reidel 1997). The letter report is being updated to reflect status and accomplishments for FY 1997 and issued as a HNF-SD-GN-ER-508 (FDH internal milestone TR-97-002, due September 26, 1997). Because of lack of funding this system has been mothballed.

Section 10.d(2) Train Post-NPH Response Team. Post-NPH reentry and damage assessment procedures were developed, and selected personal have been trained in their use. Completion of this activity [task (i) and milestone NPH-P5] is documented in WHC-SD-GN-ER-503 (Wagenblast 1996b), WHC-SD-GN-ER-504 (Wagenblast 1996a) and HNF-SD-GN-ER-505 (Conrads 1997b). Because of lack of funding this Post-NPH Response Team will not be maintained in FY 1998. 
HNF-SP- 1175

\subsection{EVALUATION PHASE COMMITMENTS}

The additional activities that were planned for accomplishment during the evaluation phase are as follows. Because of lack of funding the Evaluation Phase is suspended.

(j) Evaluate Basel ine Structures identified in Appendix $C$. The baseline structures identified in Appendix $C$ are evaluated in the order of their prioritization scores.

The priority score for facilities without prioritization worksheets is unknown. Evaluation of these facilities is deferred until existing buildings and structures with known priority are evaluated.

As stated in Section 5.2, the purpose of NPH evaluation is to remove uncertainties in the facilities NPH compliance database. This is done in four sequential steps and documented in an Evaluation Report as shown in Table 6-1. The evaluation decision process is shown in Figure 5-1 and indicates that all steps may not be required.

1st Field Verification: Obtain the database record for facility. Visit facility and verify or update facility identification, occupant identification, facility classification, safety importance and mission importance (Table 5-1, fields $C$ to $G$ ).

2nd ATC-21 Evaluation: Perform an ATC-21 rapid visual screening and complete the ATC-21 data collection form. Also update the structural description and facility condition (Table 5-1, fields $H$ and I).

3rd Records Evaluation: Search Hanford Site files, evaluate the latest existing analyses and update the design history (Table 5-1, field $\mathrm{J}$ ). Omit this step for $\mathrm{PC}-1$ facilities because the analysis rating does not affect the priority score.

4th Compliance Determination: Update the remaining fields of the database record (Table 5-1, fields $K$ through $N$ ), complete the evaluation report, and obtain the concurrence of the facility manager.

(k) Process Exemption Requests. Request exemptions for facilities identified in Appendix B in accordance with Section 9.a of the order. Follow up to assure dispositioning in a timely manner.

(1) Operate NPH Detection Instrumentation. Maintain and operate the seismic monitoring instrumentation described in WHC-SD-GN-ER-30036 (Reidel, Moore). At the end of the evaluation phase document the maintenance and operation history of the system.

(m) Recertify Post-NPH Emergency Response Team. As required, recruit, train, and certify replacements for the Post-NPH Emergency Response Team. At the end of the evaluation phase, document the 
certification status of the team and the effectivity of the reentry and detailed evaluation procedures.

(n) Develop Seismic Time Histories These will be included in a revision to HNF-PRO-97 (Conrads 1997a) and will be needed for the upgrade phase and for the design of new facilities.

(0) Manage the Compliance Baseline and Revise Implementation Plan. Update the Facilities NPH Compliance Database using the approved Evaluation Reports and DOE letters. Report the requirements baseline (Table 3-1) and facilities baseline (Appendices A, B, C and $D)$. At the end of the evaluation phase, revise and issue the Implementation Plan.

\subsection{UPGRADE PHASE COMMITMENTS}

Facilities that are candidates for upgrade are identified during the evaluation phase. Commitments and schedules for the upgrade phase are established by each responsible program for its candidate facilities.

The scope of the upgrade phase is to determine if an upgrade is necessary and cost effective, and if so, to design and construct a retrofit.

Consequently, a cost-benefit trade-off study is needed. Alternatives to be considered include retrofit, replace, deviate, mission downgrade, or assign to surplus. In parallel, the analys is is upgraded using NPH guidance in DOE-STD-1020 and HNF-PRO-97 (Conrads 1997a). The upgrade determination is based on the safety, mission, and cost impacts of the alternatives.

If, and only if, retrofit is still indicated are design and construction funding requested. When retrofit is accomplished, the facility is in compliance with the order and NPH mitigation is complete. 
Table 6-1. Natural Phenomena Hazards Evaluation Report.

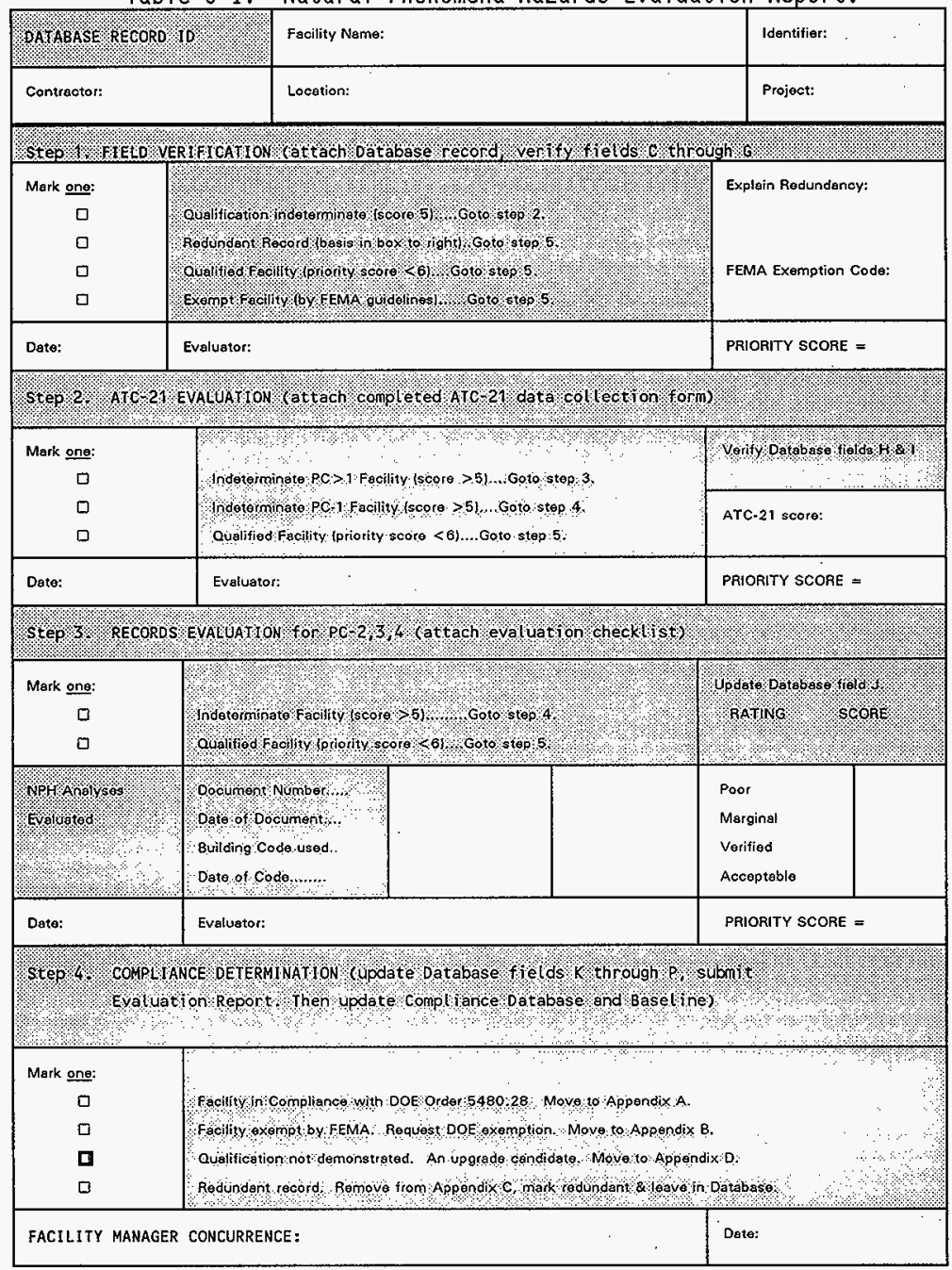


HNF-SP-1175

\subsection{GRADED APPROACH}

A graded approach is defined in 10 CFR 830.3, "Nuclear Safety Management," as a process by which the level of analysis, documentation, and actions necessary to comply with a requirement is commensurate with the following.

- Relative importance to safety, safeguards, and security (risk)

- Magnitude of any hazard involved

- Life cycle stage of a facility

- Programmatic mission of a facility

- Particular characteristics of a facility

- Any other relevant factor.

Note: Costs, resource assessment, NPH detection, and post-NPH procedures are the relevant factors considered in this implementation plan.

The additional activities proposed in Chapter 6.0 ; as well as the 7 evel of depth, rigor, and thoroughness in accomplishing them; are determined by applying the graded approach described here. The basis for the graded approach used in this implementation plan is the classification shown in Table 7-1 of facilities/SSCs in terms of their hazard category, safety class, and $P C$.

After classification of facilities/SSCs, the graded approach is established in work control documents that stipulate the level of effort needed to accomplish activities and comply with requirements. The basis for the graded approach and the work documents implementing it are discussed in the following sections.

\subsection{NATURAL PHENOMENA HAZARD ASSESSMENT AND CHARACTERIZATION}

The magnitude of any hazard [item (2) of the definition] is measured in terms of its size and type. The graded approach to hazard mitigation starts with determination of the magnitude of the unmitigated hazard. The DOE requirements and the status of assessing and characterizing NPH are discussed in Section 8.1.

In addition to NPH, dangerous materials present a hazard to DOE facilities. The magnitude of an unmitigated nuclear hazard at DOE facilities is categorized in accordance with DOE Order 5480.23. The magnitude of an unmitigated hazard due to other dangerous materials located at DOE facilities is categorized in accordance with DOE order 5481.1B. The determination. of the hazard category is included in safety analysis reports. This hazard category nomenclature is used in DOE-STD-1021-93 and also shown in Table 7-1.

\subsection{PERFORMANCE CATEgORIES}

DOE Order 5480.28 establishes five PCs for SSCs depending on their safety, mission, and cost significance [items (1), (4), and (6) of the definition]. Evaluation of the significance of these items depends on an 
understanding of the hazard, the life cycle, and facility particulars [items (2), (3), and (5) of the definition]. Requirements governing this graded approach are contained in DOE Order 5480.28 (Sections 10.b and 12) and DOE-STD-1021-93.

- Safety significance is determined in safety analyses implementing DOE Orders.

- Programmatic importance is judged based on direction received in the plant execution guidance from DOE and/or as identified by the operations divisions in conjunction with their DOE counterpart.

- Cost, except for low value and unimportant SSCs, is seldom known during the prioritization phase. Cost becomes a consideration in determining PCs whenever it is known, usually during facilityspecific evaluations.

Historically, operating contractors at the Hanford Site have classified facilities/SSCs into four safety classes depending on importance to safety. Need for a correlation among these overlapping classifications and also with hazard categories was recognized early. In response, a consensus position evolved (Webb and Conrads 1994) that expands the methodology of DOE-STD-1021-93 and defines an appropriate correlation of PCs to the existing process of SSC safety designation used by WHC. The-correlation shown in Table 7-1 is the basis of the graded approach used in this implementation plan.

\subsection{DESIGN AND EVALUATION CRITERIA}

Design and evaluation requirements based on PCs, life cycle stage, and particular characteristics of a facility [items (3) and (5) of the definition] are contained in DOE Order 5480.28, Section 10.a, and DOE-STD-1020-94.

In order to comply with these requirements and assure a graded approach, the HNF-PRO-97 (Conrads 1997a) manual was issued with three objectives.

- Integrate the new NPH requirements with existing DOE and other requirements governing design and evaluation of facilities/SSCs

- Limit requirements and NPH criteria to those applicable to the Hanford Site

- Stipulate the appropriate level of depth, rigor, and thoroughness in complying with requirements

This manual provides structural criteria governing the design of new facilities/SSCS, modifications to existing facilities/SSCs, and evaluation of existing facilities/SSCs if required. 
HNF-SP-1175

\subsection{NATURAL PHENOMENA HAZARD DETECTION AND POST-NATURAL PHENOMENA HAZARD PROCEDURES}

Requirements for NPH detection and post-NPH procedures [item (6) of the definition] are contained in DOE Order 5480.28, Section 10.d. These requirements apply only to $P C-2, P C-3$, and $P C-4$ facilities and sites.

Detection of NPH requires that instrumentation or other means are provided to detect and record the occurrence and severity of seismic events. A plan (Reidel and Moore 1996) that complies with requirements of the Order has been implemented, but because of lack of priority for funding this system has been mothballed.

Post-NPH procedures govern inspection of a facility for damage following an NPH event, placing a facility into a safe configuration when damage occurs and documenting and reporting the damage. Procedures and $\mathrm{plans}$ (Wagenblast $1996 \mathrm{a}, 1996 \mathrm{~b})$ complying with post-NPH requirements have been issued. A post-NPH emergency response team has been recruited and trained (Conrads 1997b). Because of lack of priority for indirect funding, the post-NPH emergency response teams will not be maintained starting in FY 1998.

\subsection{RESOURCE ASSESSMENT}

Resource assessments [definition item (6)] provide estimates of the monetary and nonmonetary life cycle costs of both compliance and of noncompliance. These costs are needed for performance categorization and prioritization and also provide justification for funding or for an exemption.

Resource assessment is discussed in more detail in Chapter 8.0, which also serves as the work control document for this effort.

\subsection{PRIORITIZATION}

The end item of the prioritization phase is a prioritized list for evaluation and upgrade of existing facilities/SSCS, if necessary. Requirements governing prioritization are contained in DOE Order 5480.28, Section 11.a(5). Life safety, mission importance, and resource minimization [items (1), (4) and (6) of the definition] are the stated bases for prioritization. Evaluation of these items depends on an understanding of the hazard, the life cycle, and facility particulars [items (2), (3), and (5) of the definition]. Prioritization is discussed in more detail in Chapter 8.0.

Note: These same parameters are used to establish performance categories. Prioritization of NPH puts a higher priority on life safety and provides a finer ranking of facilities/SSCs than found in the five performance categories. A procedure (Conrads 1996c) for prioritization for NPH evaluation of existing DOE facilities has been released. 
Table 7-1. Graded Approach and Performance Categorization.

\begin{tabular}{|c|c|c|c|c|c|c|}
\hline $\begin{array}{l}\text { Facility } \\
\text { Type }\end{array}$ & $\begin{array}{l}\text { Reactor or } \\
\text { Pso designated }\end{array}$ & \multicolumn{3}{|c|}{$\begin{array}{l}\text { Hazardous or Essential } \\
\text { Nonreactor Facility }\end{array}$} & $\begin{array}{c}\text { General } \\
\text { Facilities }\end{array}$ & $\begin{array}{c}\text { No } \\
\text { Safety } \\
\text { Function }\end{array}$ \\
\hline $\begin{array}{c}\text { Kazard } \\
\text { Category (2) }\end{array}$ & HC- 1 & $\mathrm{HC}-2$ & $\mathrm{HC}-3$ & Radiological & & \\
\hline
\end{tabular}

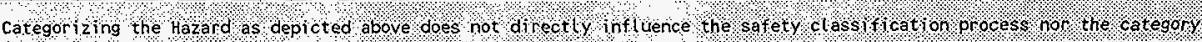

\begin{tabular}{|c|c|c|c|c|c|c|c|}
\hline \multirow{4}{*}{$\begin{array}{l}\text { Structures, } \\
\text { Systems, } \\
\text { Components, } \\
\text { Safety } \\
\text { Designation and } \\
\text { Mitigating } \\
\text { Features }\end{array}$} & \multicolumn{2}{|c|}{ Safety Class (4) } & \multicolumn{3}{|c|}{ Safety Significant (4) } & \multicolumn{2}{|c|}{ General Services } \\
\hline & \multirow[t]{2}{*}{$\begin{array}{l}\text { Performs or } \\
\text { preserves } \\
\text { reactor safety } \\
\text { function }\end{array}$} & $\begin{array}{l}\text { Prevents or } \\
\text { mitigates rad. } \\
\text { consequences } \\
\text { above risk } \\
\text { guidel ines to: }\end{array}$ & \multicolumn{2}{|c|}{$\begin{array}{l}\text { Prevents or mitigates toxic } \\
\text { chemical or onsite rad. } \\
\text { consequences above risk } \\
\text { guidelines to: }\end{array}$} & $\begin{array}{l}\text { Worker safety. } \\
\text { Prevents or mitigates } \\
\text { serious injury not } \\
\text { controlled by ISP (5) } \\
\text { to: }\end{array}$ & $\begin{array}{l}\text { occupant and } \\
\text { worker safety } \\
\text { controlled by } \\
\text { building code } \\
\text { and ISP (5) }\end{array}$ & \\
\hline & & $\begin{array}{l}\text { offsite } \\
\text { public }\end{array}$ & $\begin{array}{c}\text { offsite } \\
\text { public } \\
\text { (toxic only) }\end{array}$ & $\begin{array}{l}\text { Onsite worker } \\
\text { (rad. \& toxic } \\
\text { chemical) }\end{array}$ & $\begin{array}{l}\text { Facility } \\
\text { worker }\end{array}$ & $\begin{array}{l}\text { Any } \\
\text { occupant }\end{array}$ & $\begin{array}{c}\text { No } \\
\text { occupant }\end{array}$ \\
\hline & \multicolumn{3}{|c|}{$s c-1(6)$} & $s c-2(6)$ & $S c-3(6)$ & \multicolumn{2}{|c|}{ Nonsafety Class (6) } \\
\hline $\begin{array}{l}\text { Mission } \\
\text { Importance }\end{array}$ & \multicolumn{5}{|c|}{$\begin{array}{c}\text { Mission Importance criteria } \\
\text { TBD }\end{array}$} & $\begin{array}{l}\text { Not } \\
\text { essential }\end{array}$ & None \\
\hline Cost Imp. & \multicolumn{6}{|c|}{ Cost Importance Criteria TBD } & None \\
\hline \multirow{2}{*}{$\begin{array}{c}\text { Performance } \\
\text { Category }(1,7)\end{array}$} & $\mathrm{PC}-4$ & \multicolumn{2}{|c|}{$\mathrm{PC}-3$} & \multicolumn{2}{|r|}{$P C-2$} & $P C-1$ & $P C-0$ \\
\hline & Goal $1 \times 10^{-5}$ & \multicolumn{2}{|c|}{ Goal $1 \times 10^{-4}$} & \multicolumn{2}{|c|}{ Gool $5 \times 10^{-4}$} & Goal $1 \times 10^{-3}$ & No Goal \\
\hline
\end{tabular}

Notes: 1. DOE Program Secretarial officer (PSO) may designate a facility to a higher PC. references.

3. High, medium and low hazard class (HH, $M H \&$ LH) for non-nuclear facilities per DOE Order $5481.1 \mathrm{~B}$.

4. Safety ctass and safety significant classification per WHC-CM-4-46 Rev. 2, chapter 9.0.

4. Safety ctass and safety significant classification per WHC-CM-4-46 Rev, 2, chapter 9.0.

5. Insti tutional safety program (ISP) protecting against standard industrial hazards per DOE-STD-3009 These designations no

longer apply, but are still contained in existing safety equipment lists and reference documentation until they can be revised.

7. Performance goal and PC per DOE 5480.28 . 
HNF $-S P-1175$

\subsection{PRIORITIZATION}

\subsection{PRIORITIZATION PROCESS}

The large inventory of existing buildings and structures at the Hanford Site precludes simultaneous evaluation for NPH effects. As part of the graded approach, prioritization will result in the ranking of existing buildings and structures and allocation of resources to those buildings and structures determined to be most important and vuinerable. The process, in compliance with DOE Order 5480.28, will result in a prioritized list of buildings and structures for future NPH evaluation. This section establishes the process to be used for the prioritization of NPH evaluations.

Guidance on the minimum goals of prioritization are contained in DOE-STD-1082.

- Give primary attention to controlling and reducing risks to the public, the environment, and the workers to acceptable levels.

- Consider available information from safety analyses and other sources and use a graded approach for the acquisition of new data.

- Address programmatic constraints of time, funding, and mission when developing schedules.

- Accommodate changes at later dates.

Specific requirements governing prioritization contained in DOE Order 5480.28, Section 11.a(5) are:

- Screen and rapidly identify sites of greatest vulnerability to NPH effects

- Direct initial efforts to existing buildings and structures that are of greatest importance in terms of safety, mission, and costs

- Eliminate from further consideration existing bujidings and structures with low probability of NPH vulnerability due to their inherent ruggedness or benign site conditions.

The NPH prioritization puts a higher priority on life safety and provides a finer ranking of existing buildings and structures than found in the five performance categories in Table 7-1 and described in Section 7.2. The prioritization process used in this implementation plan is an outgrowth of a procedure (Conrads 1995) developed with consultation and cooperation from other government-owned, contractor-operated sites.

\subsection{WORKSHEET DEVELOPMENT}

Existing buildings and structures were prioritized for future NPH evaluation during the prioritization phase. Data used to establish the priority of a facility was recorded on a Prioritization Worksheet (PW), shown in Table 8-1. 
Table 8-1. Natural Phenomena Hazards Prioritization Worksheet.

\begin{tabular}{|l|l|l|}
\hline BUILDING/STRUCTURE & Name: & Number: \\
\hline floor Area $\left(\mathrm{m}^{2}\right):$ & Location: & Program: \\
\hline
\end{tabular}

\begin{tabular}{|c|c|c|c|c|}
\hline SQREENUNG & $\%$ & Yes & 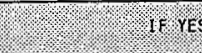 & $\mathrm{EXPl} / \mathrm{N}$ \\
\hline 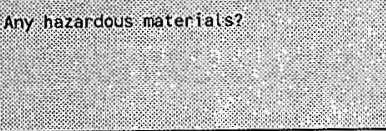 & & & 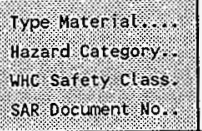 & \\
\hline 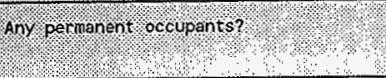 & & & 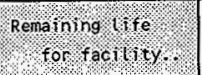 & \\
\hline Any presens or future mission? & & & $\begin{array}{l}\text { Importance to } \\
\text { progran } \ldots \ldots\end{array}$ & \\
\hline Why Whent wo restore or replace & & & Estmatedostro & $\begin{array}{l}>\$ 10,000,000 \\
<\$ 10,000,000\end{array}$ \\
\hline $\begin{array}{l}\text { IF ALL ANSWERS ARE "NO", FACILITY IS } \\
\text { UNIMPORTANT. MARK BOX PC-O AND STOP. }\end{array}$ & & \multicolumn{3}{|c|}{$\begin{array}{l}\text { IF ANY ANSWER IS "YES", FACILITY IS IMPORTANT. } \\
\text { CONTINUE AND COMPLETE PRIORITIZATION WORKSHEET. }\end{array}$} \\
\hline
\end{tabular}

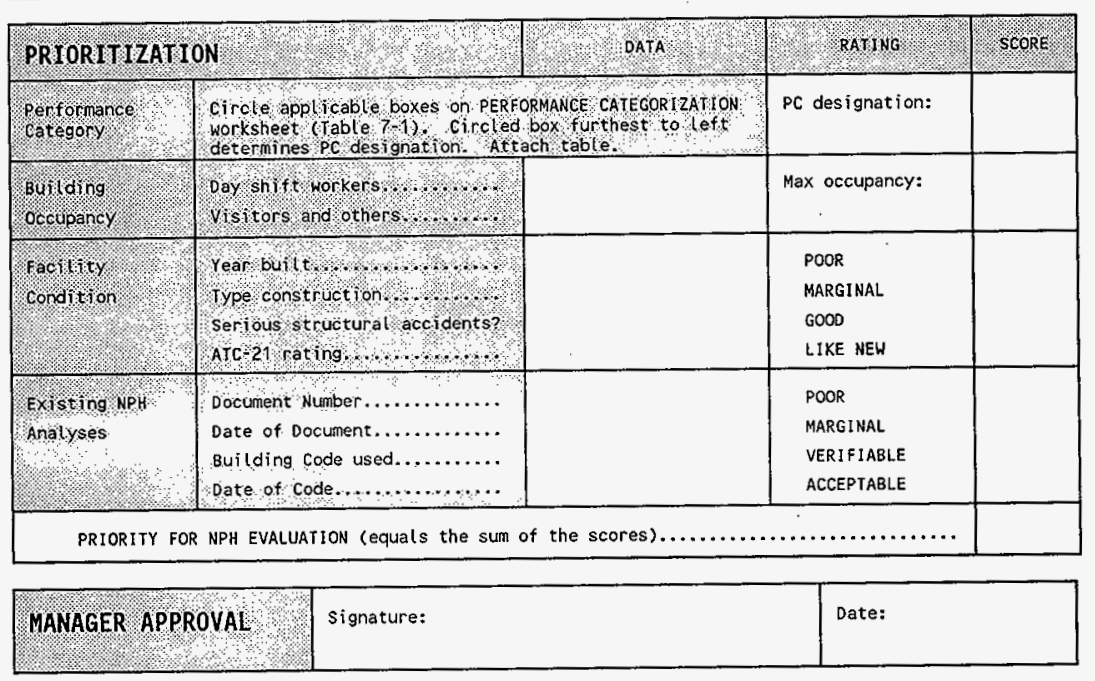


The four-step procedure used in completing the worksheet follows.

Step 1. Screen Sites for NPH Vulnerability. The first step in the prioritization process, rapid identification of sites and areas of greatest vulnerability to NPH effects, has been completed for the Hanford Site. Probabilistic NPH assessments and characterization of each site must be completed early. Based on the NPH characterization criteria developed, sites and areas of no or low NPH risk are eliminated from further consideration.

The NPH at the Hanford Site include earthquake, wind/tornado, flood, volcanic ashfal1, and lightning. New stringent requirements governing the assessment and characterization of NPH are contained in DOE Order 5480.28 (Section 10.c), DOE-STD-1022-94, and DOE-STD-1023-95. Site-specific NPH assessments have been completed for the Hanford Site. Based on these assessments, NPH characterization criteria were developed and are documented in the following:

- Tallman (1996a), Natural Phenomena Hazards, Hanford Site, South-Central Washington, WHC-SD-GN-ER-501 Rev. 0.

- Tallman (1996b), Probabilistic Seismic Hazard Analyses, DoE Hanford Site, Washington, WHC-SD-W236A-TI-002 Rev. 1.

- Conrads (1996d), Volcanic Ashfa7l Loads for the Hanford Site, WHC-SD-GN-ER-30038 Rev. 0.

These documents indicate a higher level of NPH risk than shown in earlier Hanford Site design criteria. Facilities/SSCs built to previous Hanford Site design criteria met previous criteria, usually with generous margins of safety. However, because of the new criteria, existing facilities/SSCs may be considered at risk until they are evaluated in accordance with the current $\mathrm{NPH}$ criteria contained in DOE-STD-1020 and HNF-PRO-97 (Conrads 1997a).

Based on the NPH characterization criteria, no area within the Hanford Site can be eliminated from further consideration because of no or low NPH risk. Except for flood, all areas within the Hanford Site have relatively the same vulnerability to NPH effects.

Step 2. Screen out Unimportant Buildings and Structures. The next step in the prioritization process is identifying unimportant existing buildings and structures, documenting the process, and eliminating the unimportant buildings from further consideration.

Unimportant buildings and structures are designated $\mathrm{PC}-0$ and do not require NPH qualification or mitigation. These are defined as nonhazardous, unoccupied, low value, and nonessential buildings and structures where NPH is not an issue. The PC-0 buildings and structures must meet all of the following unimportance criteria:

- No hazardous material contained or stored within

- No permanent occupants

- No current or future mission

- No requirement nor intent to restore or replace. 
Examples of $\mathrm{PC}-0$ bujlding or structure include an unused guardhouse awaiting a decision on deactivation, a deactivated substation visited on a regular basis only by security, and structures currentiy being deactivated or decommissioned.

Note: As shown in Table 7-1, PC-0 is a more-limited application than the obsolete nonsafety class (sometimes called SC-4) designation which included both PC-1 and PC-0. The NPH and other structural design and evaluation criteria apply only to PC-0 SSCS in "3-over-1" situations. That is, when failure or damage to a PC-0 SSC in an accident or NPH event could jeopardize a higher-PC-level SSC, the criteria governing the higher-level PC is used for the design evaluation of the PC- 0 SSC.

Step 3. Prioritize Important Buildings and Structures. Existing buildings and structures not designated $P C-0$ are important and are prioritized for evaluation based on the following priority factors.

- Performance Category

- Occupancy Considerations

- Facility Condition

- Existing Analysis

For each priority factor, a building or structure is assigned a numerical score $(0$ to 10), and the unweighted scores are added to generate the total score. Higher scores signify a higher priority for possible future NPH evaluation.

\section{Performance Categories}

DOE Order 5480.28 requires that, for the purposes of NPH design and evaluation, facilities/SSCS be placed in one of five performance categories. Performance categories are established for facilities/SSCs on the basis of their safety, mission, and cost significance. Performance categories are the basis for the graded approach used in this implementation plan, and are discussed in Section 7.2.

Performance categorization is considered appropriate for scaling the potential impact of an NPH event on an existing building or structure. Prioritization scores for the potential building/structure hazard are assigned, based on the following PCS.

\begin{tabular}{cr}
\multicolumn{2}{c}{ Performance } \\
Category & $\frac{\text { Score }}{10}$ \\
\hline$P C-4$ & 5 \\
$P C-3$ & 3 \\
$P C-2$ & 1 \\
$P C-1$ & 0 \\
$P C-0$ &
\end{tabular}

Occupant Considerations

The higher PCS (PC-4, PC-3, and PC-2) are mostly concerned with the risks to the offsite population and to onsite personnel. For example, the Plutonium Finishing Plant (PFP) is designated as a PC-3 building; whereas, an office 
building is typically designated as a PC-1 structure. Occupancy considerations in this prioritization process emphasize the life safety of workers and visitors in a building.

The occupancy loading of a building is representative of the relative risk to building occupants due to structural failure or collapse during or after a NPH event. Occupancy is taken as the number of people continuously occupying the building for more than 2 hours.

Prioritization scores are assigned based on the maximum allowed building occupancy, $N$. That is, the sum of the normal shift staff plus visitors in conference rooms, auditoriums, etc.

\begin{tabular}{rr} 
Occupancy $N$ & Score \\
\hline$N>100$ & 10 \\
$10 \leq N \leq 100$ & 5 \\
$1 \leq N<10$ & 1 \\
0 & 0
\end{tabular}

\section{Facility Condition}

Facility condition encompasses the design capacity of the facility for NPH loads and any degradation of the structure or the foundation that may have reduced that capacity. Buildings and structures normally deteriorate with age or are modified to accommodate a new mission. The rate of deterioration is a function of the maintenance program and any unusual historical structural incidents such as accidents, restorations, and modifications. With nominal maintenance and.no major structural incident, and for the purpose of prioritization for NPH evaluation, the facility can be assumed to deteriorate as follows.

- First 5 years. Facility condition should be considered like new.

- Age 6-10 vears. Facility condition should be considered good.

- Age 11-25 years. Facility condition should be considered marginal.

- After 25 years. Facility condition should be considered poor.

If the facility has experienced a serious structural accident or major modification, the above deterioration schedule may not be conservative. In this case a field walkdown to determine the facility condition is indicated. A widely recognized methodology has been developed by the Applied Technology Council (ATC) and endorsed by FEMA. This approach is set forth in ATC-21, 1988, Rapid Visual Screening of Buildings for Potential Seismic Hazards, (also FEMA 154,1988 ).

The procedure is a ranking process to develop the relative capacity of structures to prioritize their detailed evaluation or to determine if detailed evaluation is even necessary. A primary evaluation criteria under this methodology is based on the type of structure. The ATC-21 identifies 12 building categories and the relative seismic resistance of each type.

The historical performance of these classifications of structures is known and includes assessment of degradation mechanisms such as rusting of 
structural steel frames, mortar degradation in masonry structures, wood rot, etc. This methodology assigns a rating based on the sum of values assigned to evaluation attributes. The higher the ATC rating, the greater the inherent seismic and other NPH resistance.

If there has been no serious structural accident, prioritization scores for the facility condition are assigned on the basis of the age of the facility. If there has been a serious structural accident, the prioritization score should be based on the ATC- 21 ratings. If that is not feasible, a prioritization score of 10 should be assigned. The schedule for scoring is as follows:

\begin{tabular}{|c|c|c|c|}
\hline 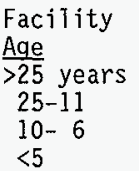 & $\begin{array}{c}\text { ATC-2I } \\
\frac{\text { Rating }}{<0} \\
0-3 \\
>3\end{array}$ & $\begin{array}{l}\text { Facility } \\
\text { Condition } \\
\text { Poor } \\
\text { Marginal } \\
\text { Good } \\
\text { Like new }\end{array}$ & $\begin{array}{c}\text { Score } \\
10 \\
5 \\
1 \\
0\end{array}$ \\
\hline
\end{tabular}

\section{Existing Anaiysis}

The methodology of NPH evaluation, especially for seismic loads, has evolved significantly over the past 20 years. Consequently, the quality of an evaluation of a structure's capability to adequately resist $\mathrm{NPH}$ loads is largely a function of the age of the structure. Other important quality considerations are whether the evaluation uses the correct NPH criteria and codes and has been, or can be, verified. A four-tier classification is used to describe the quality of NPH structural documentation.

- Poor. Documentation has not been found or is greater than 20 years 01d. The 20-year-old analysis restriction is based on the issue of the 1976 Uniform Building Code (UBC) where unified seismic analysis methodology was promulgated.

- Margina1. Documentation exists and is dated after 1976. Such analyses may or may not comply with NPH requirements found in HNF-PRO-97 (Conrads 1997a).

- Verified. Documentation exists, was performed after 1990 , and has been verified by external review. UCRL-15910, issued June 1990, contained the mandatory NPH methodology and a graded approach on which DOE order 5490.28 is built. These quality evaluations approach compliance with NPH requirements of HNF-PRO-97 (Conrads 1997a).

- Acceptable. Documentation exists and is supported by retrievable, verifiable calculations that comply with NPH requirements in HNF-PRO-97 (Conrads 1997a). Such an evaluation was performed to currently acceptable methods, acceptable NPH Tevels (current seismic response spectra, American National Standards Institute or equivalent wind speeds, etc.), and consensus codes (American Society of Mechanical Engineers, American Institute of Steel Construction, and American Concrete Institute). 
Care should be taken that the entire structure and foundation have been adequately evaluated. Where several $\mathrm{NPH}$ structural and geotechnical reports exist, the documentation classification should reflect the quality of the least adequate of the necessary evaluations.

The condition of documentation is important mainly for the higher performance categories, $P C-4, P C-3$, and $P C-2$. External review (e.g., DOE, Defense Nuclear Facility Safety Board) of NPH designs and evaluations is typically performed only on the higher PC facilities/SSCS. On the other hand, analyses for PC-1 facilities/SSCs can be assumed as acceptable, based on the completion of construction in accordance with the $\mathrm{UBC}$.

Prioritization scores for existing analyses are assigned based on the quality of documentation and on the $P C$ as follows.

$\begin{array}{lccc}\text { Documentation } & & & \\ \text { Quality } & \frac{P C-3}{-2}-4 & \frac{P C-1}{5} & \frac{P}{0} \\ \text { Poor } & 10 & 3 & 0 \\ \text { Marginal } & 5 & 1 & 0 \\ \text { Verified } & 1 & 0 & 0 \\ \text { Acceptable } & 0 & \end{array}$

Step 4: El imination of Inherently Rugged Buildings and Structures. The final step in the prioritization process is described in Section 11.a(5) of DOE Order 5480.28:

"Areas where SSCS might not be vulnerable to NPH effects due to inherent ruggedness or benign site conditions can be identified and eliminated from further consideration."

The approach used in this implementation plan is to identify a conservative cutoff value of the prioritization score that separates inherently rugged buildings and structures from less rugged facilities that require $\mathrm{NPH}$ evaluation.

To be inherently rugged the facility condition must be "good" or "like new," and the existing analyses must be "verifiable" or "acceptable." To be conservative, the building occupancy should be nine persons or less. The maximum and minimum prioritization scores considering these restraints are in Tabie 8-2. 
Table 8-2. Prioritization Scores for Inherently Rugged Facilities.

\begin{tabular}{|c|c|c|c|c|}
\hline Performance Category & $\mathrm{PC}-4$ & 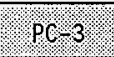 & $(\mathrm{PC}-2$ & .90 .1 \\
\hline $\begin{array}{l}\text { CUT'-orf SCORES for } \\
\text { Performance category }\end{array}$ & 10 & 5 & 3 & 1 \\
\hline Buliding occupancy & \multirow{3}{*}{$\begin{array}{l}\text { n/a (10 } \\
\text { exceeds } \\
\text { limit) }\end{array}$} & 0 & \multirow{3}{*}{$\begin{array}{l}\text { Pick 2 } \\
\text { (not 3) }\end{array}$} & 1 \\
\hline (ractility condition. & & 0 & & 1 \\
\hline Existing inatissis: & & 0 & & 0 \\
\hline : RUGGED RANGE & None & 5 & 5 to 3 & 3 to 1 \\
\hline FULL RANGE & 40 to 10 & 35 to 5 & 28 to 3 & 21 to 1 \\
\hline
\end{tabular}

The cutoff prioritization score, "5", is selected to eliminate inherently rugged buildings and structures. No $\mathrm{PC}-4$ facilities are eliminated from evaluation because their minimum score is 10 . A PC-3 facility must be unoccupied, like new, and with acceptable documentation to be eliminated. For a.PC-2 facility to have a score of 5 or less, it must be unoccupied, like new, or have acceptable documentation. Because the scores for both building occupancy and facility condition go $0,1,5,10$; only PC-1 facilities with scores of "1" for these prioritization factors can be eliminated.

The intent of this prioritization process is to identify buildings and structures with scores of 5 or less as inherently rugged and to eliminate them from further NPH consideration. Because this is the stated intent of DOE Order 5480.28, no wavier will be requested.

\subsection{PRIORITIZATION SCHEDULE}

A prioritization worksheet is filled out for each existing building or structure by the program manager and/or landlord responsible for the facility. Information from the completed prioritization worksheets is entered into the Facility NPH Compliance Database. The updated database is sorted by prioritization scores to divide existing facilities into the following groups.

\subsubsection{Existing Facilities in Compliance with DOE Order 5480.28.}

Facilities whose total priority score is 5 or less are in compliance with requirements of the order. This group currently contains unimportant facilities in PC-0 identified by prioritization scores of 0 , and inherently rugged facilities identified by prioritization scores in the range of 1 to 5 .

Appendix A identifies this group of facilities and is the NPH Compliance Baseline for New and Existing Buildings and Structures in Compliance with DOE Order 5480.28. This baseline uses conservative assumptions and is small at the present time. 
HNF-SP-1175

\subsubsection{Existing Facilities where Compliance Has Not Been Determined.}

The large group of all other FDH facilities at the Hanford Site can be subdivided as follows.

Concurrent with responding to the NPH mitigation requirements of the DOE Order, FDH was requested to inventory existing federally owned or leased buildings using criteria contained in DOE's Management Plan for Compliance to Executive Order (EO) 12941. Fortunately, with a minor restructuring, the NPH Compliance Database was adapted to support both the DOE NPH mitigation program and the EO seismic safety program. The EO inventory has been identified and transmitted to DOE (Whalen 1997).

The two programs differ in their identification of benign or low-risk facilities. Section 11.a(5) of the DOE Order 5480.28 el iminates from further consideration unimportant facilities and inherently rugged facilities. In this implementation plan unimportant facilities are identified as PC-0, and inherently rugged facilities are identified by a prioritization score of 5 or less. FEMA eliminates from further consideration facilities meeting one or more of nine exemption criteria (see ICSSC RP 4 [1994] and Table 5-2 of FEMA handbook ICSSC TR-17 [1995]). Four FEMA exemption criteria shown in Tabie 8-3 are applicable to Hanford Site facilities and were used in the EO inventory.

Table 8-3. Federal Emergency Management Agency Exemption Criteria.

\begin{tabular}{|c|l|}
\hline CODE & \multicolumn{1}{|c|}{ EXEMPTION } \\
\hline EI & $\begin{array}{l}\text { Incidental human occupancy, or } \\
\text { occupied less than 2 hours a } \\
\text { day. }\end{array}$ \\
\hline E3 & $\begin{array}{l}\text { Less than 280 } \mathrm{m}^{2} \text {, one-story, and } \\
\text { light stee1 frame or wood } \\
\text { construction }\end{array}$ \\
\hline E5 & $\begin{array}{l}\text { Post-benchmark building per } \\
\text { table 1 of RP 4. }\end{array}$ \\
\hline E8 & $\begin{array}{l}\text { Less than } 5 \text { years useful } \\
\text { remaining 1ife. }\end{array}$ \\
\hline
\end{tabular}

None of the FEMA exemptions are applicable "for buildings which require a seismic performance objective beyond Substantial Life-Safety because of agency mission requirements." (ICSSC RP-4, Section 1.3). Consequent7y, FEMA exemptions at the Hanford Site are only applicable to $P C-1$ and $P C-0$ facilities.

Because the safety objectives of DOE and FEMA are closely compatible, and the resources for accomplishing NPH mitigation are scarce, the FEMA exemption 
criteria are used to sort the existing facilities where compliance has not been determined into the following two categories:

- Existing Facilities where an Exemption is being Requested.

The database is sorted for PC-1 facilities that are exempt by FEMA criteria. Generally, this group has low priority scores and, consequentiy, low evaluation priority. A request for exemption could be submitted to DOE as discussed in paragraph 11.0.

Appendix B lists this group of facilities and is the NPH Compliance Baseline for Existing Buildings and Structures where an Exemption is being Requested. Until the request is acted on, this group will be put on "hold." If DOE approves some exemptions, those facilities will be considered in compliance with the order and listed in Appendix $A$ of the Compliance Baseline. If DOE disapproves other exemptions, those facilities will be scheduled for evaluation and added to Appendix $C$ of the Compliance Baseline.

- Existing Facilities Requiring NPH Evaluation.

This group contains the remainder of those facilities where compliance has not been determined. These are existing buildings and structures for which no exemption is requested, or where DOE disapproves an exemption.

Appendix $C$ describes this group of facilities. The list in Appendix $\mathrm{C}$ is ranked by the priority score of the facility. NPH evaluations are then scheduled in the order of priority scores. Appendix $C$ is the Compliance Baseline and Prioritized Schedule for Existing Buildings and Structures Requiring NPH Evaluation. 


\subsection{RESOURCE ASSESSMENT}

Resource assessments provide estimates of the monetary and nonmonetary life cycle costs of both compliance and noncompliance with DOE order 5480.28. The goals of resource assessments include the following:

- Communicate the expected new costs of Order implementation for performance categorization, prioritization, and budget planning

- Explore more cost-effective means of achieving compliance

- Identify cases where exemptions should be requested on the basis of insufficient benefit versus the expected implementation costs.

The effort used to develop the resource assessment is 1 imited to oniy that level of detail necessary to achieve these goals. Assessments are guided as much as possible by readily available, relevant quantitative, and qualitative information.

\subsection{ASSESSMENT METHODOLOGY}

Considerations to be included in a resource assessment are suggested in DOE-STD-1082. The eight-step methodology presented below is based on these considerations. Steps (a) through (e) are repeated for each phase. Steps (f) and (g) are facility specific and are completed during the upgrade phase.

(a) Bases for Assessment. The additional activities proposed to achieve full compliance with DOE Order 5480.28 are identified in Chapter 6.0. The assessment depends on the scope of these activities. Size, quantities, boundaries, constraints, assumptions, and other considerations affecting the assessment should be stated along with justification for their use.

(b) Alternative Selection. Alternative, feasible means of compliance are to be identified. The rationales for rejection and selection should be provided.

(c) Additional Program Costs. An estimate of the costs for the proposed activities is to be developed. These costs are additional to existing program budgets.

During the mobilization, prioritization, and evaluation phases, program operations are uninterrupted and life cycle costs are not a consideration. However, during the upgrade phase, facilities may be shutdown or program operations may be affected. After the upgrade is completed, operations and operating costs may be different than before. Consequently, the estimate (made during the upgrade phase) of additional funds needed for upgrade depends on the difference between the pre-and post-upgrade 1 ife cycle cost. 
(d) Availability of Resources. Estimates of monetary costs and schedules can be affected by the available nonmonetary resources. The scarcity or abundance of skilled labor, needed materials, and special services should be determined. Any adverse impact on costs or schedules should be identified.

Facility-specific information on plant conditions, configurations, and processes is another important consideration for estimates made during the upgrade phase.

(e) Sources of Funding by Fiscal Year. After considering the availability of resources, an estimate of funds needed in each fiscal year is tabulated. These funds are then allocated to programs. The impact of nonavailability of funds should be discussed.

(f) Value of Expected Benefits. The benefits of compliance are equal to the monetary and nonmonetary costs that would be incurred if an NPH event occurred prior to compliance. Figures of merit for these casts are lives jeopardized, days of mission downtime, and cost of facility rehabilitation.

The purpose of quantifying these benefits is to establish the cost benefit of compliance leading to a decision on whether to mitigate or to waive requirements of DOE Order 5480.28. These are facility-specific decisions and will be made during the upgrade phase.

(g) Cost Benefits of Compliance. In this implementation plan, the cost benefits of compliance are measured by the ratios of the cost of compliance to value of the expected benefits. In order of importance, these ratios are as follows:

- Costs per life not jeopardized

- Costs per day of mission downtime avoided

- Costs of compliance to costs of rehabilitation.

(h) Request for Exemption. An insufficient benefit versus the expected implementation costs can provide a basis for an exemption request.

\subsection{MOBILIZATION PHASE RESOURCE ASSESSMENT}

The mobilization phase for DOE Order 5480.28 has been completed. During FY 1996, $\$ 465,000$ of overhead funds were spent on this phase. 


\subsection{PRIORITIZATION PHASE RESOURCE ASSESSMENT}

During FY 1997, $\$ 498,000$ of overhead funds were spent on this phase. The prioritization phase for DOE Order 5480.28 has been suspended because of lack of priority for funding.

\subsection{EVALUATION PHASE RESOURCE ASSESSMENT}

(a) Bases for Assessment. The additional activities proposed to be accomplished are identified in Section 6,3. The amount of work to be done is primarily a function of the number of facilities to be evaluated, the availability of information, and the time to acquire and process missing data. Table 9-1 shows the scope of the evaluation effort. A trained team is estimated to take on average 3.5 work hours to evaluate one facility. .

Table 9-1. Bases for Assessment.

\begin{tabular}{|l|c|}
\hline Evaluation Tasks (from Section 6.3) & Facilities \\
\hline Task (j) Evaluate Facilities & \\
Start of Evaluation Phase: & \\
Prioritization worksheets on hand & 131 \\
TwRS - - worksheets to be submitted & 545 \\
Other - database records, no worksheets & $\frac{184}{860}$ \\
Appendix C: To be evaluated & \\
Task (k) Process Exemptions & \\
Appendix B: Exemptions requested & 310 \\
Task (1) Operate NPH Detection Network & \\
Task (m) Recertify Post-NPH Response Team & \\
Task (n) Develop Seismic Time Histories & \\
Task (o) Manage Baseline \& Report in IP & \\
Appendix A: Facilities in & \\
Nompliance & \\
\hline
\end{tabular}

(b) Alternative Selection. The alternative, feasible means of evaluating existing facilities that were considered are as follows:

- Alternative 1. Outsource all activities in the evaluation phase under the direction of Numatec Hanford Corporation (NHC). 
Rejected. The coordination and cooperation of the many programs/landlords would be difficult to obtain. There would be a schedule slip in contracting and funding the outsources.

- Alternative 2. Program/landiords evaluate their facilities [task $(j)$ ] and provide funding for their activities. NHC would be responsible for sitewide activities and overall direction [tasks (k) through (0)].

Rejected. Evaluation is most consistent and cost effective when a small, trained team performs an ATC-21 type rapid visual screening after verifying data provided by program/landlords.

- Alternative 3. Program/landlords complete and submit prioritization worksheets for their facilities and provide field support for the Evaluation Team. NHC staffs and trains the Evaluation Team, accomplishes and documents evaluations of existing facilities, and performs sitewide activities [tasks (j) through (0)].

Selected. This alternative provides defensible, timely, and cost-effective evaluations. It also provides for updating and reporting the compliance baseline in annual revisions to the implementation plan.

(c) Additional Program Costs. The commitments identified and described in Section 6.3 define the additional work to be done. Using the bases for assessment from Table 9-1 and the selected alternative 3, the additional program cost originally projected for FY 1998 is estimated to be $\$ 572,000$.

(d) Availability of resources. Labor and computing time are the main non-monetary resources needed for evaluation.

- Experienced engineers and computing specialists are available at the Hanford Site.

- Work stations and/or the Hanford Site mainframe computer are available.

No scarcity of resources and no adverse impacts are anticipated on costs and schedules.

(e) Sources of Funding by Fiscal Year. The evaluation phase as a follow-on to the prioritization phase is suspended.

(f) Value of Expected Benefits. Not applicable to the evaluation phase.

(g) Cost Benefit of Compliance. Not applicable to the evaluation phase.

(h) Request for Exemption. Appendix $B$ identifies the facilities for which exemptions could be requested. The basis for requesting exemptions is discussed in Chapter 11.0. 
HNF-SP-1175

\subsection{UPGRADE PHASE RESOURCE ASSESSMENT}

To be determined. See Section 6.4 
HNF-SP-1175

This page intentionally left blank. 
HNF-SP-1175

\subsection{MILESTONES AND SCHEDULES}

The milestones and achievable schedules proposed in this chapter are based on and consistent with earlier sections of this implementation plan.

- DOE Order 5480.28 becomes immediately in-force at the effective date of the last applicable standard. As discussed in Section 2.1, the in-force date is established by DOE-RL. The order also requires submittal of an implementation $\mathrm{plan}$ within 1 year of the effective date of the last standard.

- Proposed milestones correspond one-for-one with the additional activities in Chapter 6.0. Deliverables defining closure of milestones are also identified.

- Site NPH hazards assessments (Conrads 1996d, Tallman 1996a) were completed during the mobilization phase and are to be used in facility NPH assessments in the upgrade phase.

- Estimates of needed funding are shown in Chapter 9.0. No major impacts to activities or commitments outside the scope of this plan have been identified.

On approval and funding of the implementation $\mathrm{plan}$, the milestones and schedules shown in this section are enforceable commitments. The commitment tracking system is discussed in Chapter 13.0. Tracking numbers for milestones are shown below.

\section{I MOBILIZATION PHASE MILESTONES AND SCHEDULE}

The mobilization phase for DOE Order 5480.28 has been completed. WHC-SP-1175 Rev. 0 (Conrads 1996b), the prior issue of the implementation plan, describes accomplishments and status at that time.

\subsection{PRIORITIZATION PHASE MILESTONES AND SCHEDULE}

The remaining activities of the prioritization phase are suspended. Prioritization phase milestones have been completed as shown in Table 10-1.

\subsection{EVALUATION PHASE MILESTONES AND SCHEDULE}

The proposed milestones to be completed during the evaluation phase are shown in Table 10-2. 
Table 10-1. Completed Prioritization Phase Milestones and Schedule.

\begin{tabular}{|c|l|c|}
\hline $\begin{array}{c}\text { Tracking } \\
\text { Number }\end{array}$ & \multicolumn{1}{|c|}{ Milestone (Deliverable End Item) } & $\begin{array}{c}\text { Schedule } \\
\text { (Actual) }\end{array}$ \\
\hline NPH-P1 & Funding for Prioritization Phase available & $\begin{array}{c}10-1-96 \\
(10-1-96)\end{array}$ \\
\hline NPH-P2 & $\begin{array}{l}\text { Prioritize Facilities for NPH Vulnerability } \\
\text { (HNF-SP-1175, Appendix C)-partially complete }\end{array}$ & $\begin{array}{c}5-15-97 \\
\text { Conrads 1997a }\end{array}$ \\
\hline NPH-P3 & $\begin{array}{l}\text { Establish Facilities NPH Compliance Baseline } \\
\text { (HNF-SP-1175, Appendixes A, B, C and D) }\end{array}$ & $\begin{array}{c}5-15-97 \\
\text { Conrads 1997a }\end{array}$ \\
\hline NPH-P4 & $\begin{array}{l}\text { Install NPH Detection Instrumentation } \\
\text { (letter report, Seismic Monitoring System) }\end{array}$ & $\begin{array}{c}5-15-97 \\
\text { ReideT }\end{array}$ \\
\hline NPH-P5 & $\begin{array}{l}\text { Train Post-NPH Response Team and Alter } \\
\text { Emergency Procedures (HNF-SD-GN-ER-505) }\end{array}$ & $\begin{array}{c}4-15-97 \\
\text { Conrads 1997b }\end{array}$ \\
\hline NPH-P6 & $\begin{array}{l}\text { Submittal of implementation plan to RL and } \\
\text { funding requirements for Evaluation Phase } \\
\text { (HNF-SP-1175, to DOE-RL) }\end{array}$ & $\begin{array}{c}5-15-97 \\
\text { Conrads 1997a }\end{array}$ \\
\hline
\end{tabular}


Table 10-2. Proposed Evaluation Phase Milestones and Schedule.

\begin{tabular}{|c|l|l|}
\hline $\begin{array}{c}\text { Tracking } \\
\text { Number }\end{array}$ & \multicolumn{1}{|c|}{ Milestone (Deliverable End Item) } & \multicolumn{1}{|c|}{$\begin{array}{c}\text { Schedule } \\
\text { (Actual) }\end{array}$} \\
\hline NPH-E1 & $\begin{array}{l}\text { DOE approval of implementation plan and } \\
\text { funding for Evaluation Phase available }\end{array}$ & TBD \\
\hline NPH-E2 & $\begin{array}{l}\text { Evaluate existing facilities in Appendix C } \\
\text { (Letter report with Evaluation Worksheets) }\end{array}$ & TBD \\
\hline NPH-E3 & $\begin{array}{l}\text { Process exemption requests in Appendix B } \\
\text { (FDH Tetters to/from DOE) }\end{array}$ & TBD \\
\hline NPH-E4 & $\begin{array}{l}\text { Operate NPH Detection Instrumentation } \\
\text { (Letter report, Seismic Monitoring System) }\end{array}$ & TBD \\
\hline NPH-E5 & $\begin{array}{l}\text { Recertify Post-NPH Emergency Response Team } \\
\text { (HNF-SD-GR-ER-505 rev 1) }\end{array}$ & TBD \\
\hline NPH-E6 & $\begin{array}{l}\text { Deveiop seismic time histories } \\
\text { (HNF-PR-000097 rev 1) }\end{array}$ & TBD \\
\hline NPH-E7 & $\begin{array}{l}\text { Report baseT ine \& Evaluation Phase results } \\
\text { (HNF-SP-1175, IP Rev. 2 to RL) }\end{array}$ & TBD \\
\hline
\end{tabular}


HNF-SP-1175

This page intentionally left blank. 


\subsection{EXEMPTIONS}

Exemptions are authorizations to exclude something from requirements. Deviations are authorizations to depart from particular requirements and comply in a more appropriate, specified manner. Deviations are usually granted before-the-fact; when granted after-the-fact, they are often referred to as waivers. Exemptions and deviations are requested in accordance with Section 9 of DOE Order 5480.28, and must be approved in writing by DOE.

As described in Section 8.3, during the prioritization phase, a number of existing buildings and structures were identified as candidates for exemption. Appendix B is a listing of these facilities and is the NPH Compliance Baseline for Existing Buildings and Structures where an Exemption could be Requested.

The bases for the exemption requests is that these are very low NPH risk facilities and that further evaluation would not be cost effective. These are facilities that meet the FEMA exemption criteria authorized by E0 12941. The rationale for the low risk is discussed in the FEMA Handbook (ICSSC TR-17).

The FEMA eliminates from further consideration facilities meeting one or more of nine exemption criteria (see ICSSC RP 4 and Table 5-2 of FEMA-handbook ICSSC TR-17). During prioritization, four FEMA exemption criteria were found to be applicable to facilities at the Hanford Site. Table 11-1 shows these applicable exemption criteria and the number of facilities meeting the criteria and for which exemptions are being requested. For each facility the FEMA code justifying the exemption request is shown in the second column of Appendix B.

Table 11-1. FEMA Exemptions.

\begin{tabular}{|c|l|c|}
\hline FEMA CODE & \multicolumn{1}{|c|}{ FEMA EXEMPTION CRITERIA } & REQUESTS \\
\hline E1 & $\begin{array}{l}\text { Incidental human occupancy, or } \\
\text { occupied less than } 2 \text { hrs a day. }\end{array}$ & 87 \\
\hline E3 & $\begin{array}{l}\text { Less than 280 } \mathrm{m}^{2} \text {, one-story, and Tight } \\
\text { steel frame or wood construction }\end{array}$ & 162 \\
\hline E5 & $\begin{array}{l}\text { Post-benchmark building per Table 1 of } \\
\text { RP 4. }\end{array}$ & 48 \\
\hline E8 & $\begin{array}{l}\text { Less than 5 years useful remaining } \\
\text { life. }\end{array}$ & 13 \\
\hline
\end{tabular}

None of the FEMA exemptions are applicable "for buildings which require a seismic performance objective beyond Substantial Life-Safety because of agency mission requirements" (ICSSC RP-4, Section 1.3). Consequent7y, at the Hanford Site the FEMA exemptions are not applicable to $P C-2, P C-3$ or $P C-4$ facilities. 
Appendix B lists only facilities: (a) designated PC-1, (b) exempt by FEMA criteria, (c) for which a prioritization worksheet is submitted by the program manager or landlord, and (d) with a priority score greater than 5 (that is important, not inherently rugged facilities). Generally, facilities in Appendix B have low priority scores, and consequently have low evaluation priority.

Until the request is dispositioned by DOE, this group witl be put on "hold." If DOE approves some exemptions, those facilities will be in compliance with the Order and moved into Appendix A of the Compliance Baseline. If DOE disapproves other exemptions, those facilities will scheduled for evaluation and added to Appendix $C$ of the Compliance Baseline.

During the evaluation and upgrade phases, additional conditions may be discovered that warrant exemptions or deviations. If an exemption or deviation is requested in the future, the request will comply with requirements of Section 9 of DOE Order 5480.28 . 
HNF-SP-1175

\subsection{COMPENSATORY ACTIONS}

Compensatory actions are temporary actions taken to provide adequate protection of individuals and environment prior to full implementation of requirements. This section describes the compensatory actions taken or to be taken before full implementation of DOE Order 5480.28.

\subsection{NEW FACILITIES/SSCS}

The definition of a new facility/SSC used in this implementation plan is:

A new facility/SSC is one in which Conceptual Design is started after the effective date of DOE Order 5480.28. Facilities/SSCs in the planning, engineering study, and preconceptual design stage on or after the effective date of DOE order 5480.28 are new facilities/SSCs.

Facilities/SSCs that have started Conceptual Design prior to the effective date of DOE Order 5480.28 are existing facilities/SSCs. (Wise 1994)

It was also recommended by WHC (Wise 1996) that the effective date be defined as 60 days following the issue of HNF-PRO-97 (Conrads 1997a).

No compensatory actions are required. The HNF-PRO-97 (Conrads 1997a) manual integrates the new Hanford Site NPH characterization criteria with DOE order 5480.28 and other structura? requirements. The design of new facilities/SSCs and new modifications to existing facilities/SSCs to HNF-PRO-97 (Conrads 1997a) criteria will be in compliance with DOE Order 5480.28.

\subsection{EXISTING BUILDINGS AND STRUCTURES}

The NPH characterization criteria developed in accordance with DOE Order 5480.28 (Section 10.C), DOE-STD-1022-94, and DOE-STD-1023-95 indicate a higher level of risk than earlier Hanford Site design criteria. Facilities or SSCS built to previous Hanford Site design criteria met previous criteria, usually with a generous margin of safety. However, these existing facilities/SSCS may or may not be at risk until they are evaluated in accordance with the new NPH criteria contained in HNF-PR0-97 (Conrads 1997a).

Compensatory actions are being taken in accordance with the phased approach described in paragraph 1.2.

- Existing buildings and structures are prioritized and evaluated as described in Chapter 10.0 to identify facilities that are known to comply with requirements of DOE Order 5480.28 .

- After evaluation, facilities not known to be in compliance are candidates for upgrade. An upgrade determination will be based on a trade-off study comparing the feasible alternative courses of action. If a retrofit is recommended, authorization and funding will be requested of DOE. 
HNF-SP-1175

This page intentionally left blank. 


\subsection{TRACKING}

Commitments are described in Chapter 6.0. Milestones and a completion schedule associated with these commitments are proposed in Chapter 10.0. On approval and funding of the implementation plan, these milestones and the completion schedule are enforceable commitments. Tracking numbers are assigned for milestones and are shown in Chapter 10.0 .

FDH has assigned responsibility to NHC for tracking these commitments. Accomplishment of these commitments and definition of new commitments will be reported at the end of the evaluation phase in a revision of this implementation plan.

Information on the status of these commitments or any questions regarding this implementation plan should be directed to NHC. 
HNF-SP-1175

This page intentionally left blank. 


\subsection{REFERENCES}

\subsection{REQUIREMENTS DOCUMENTS}

10 CFR Part 830, "Nuclear Safety Management," Code of Federa7 Regulations, as amended.

42 US Code 7701 et seq, Earthquake Hazards Reduction Act of 1977.

DOE Order 420.1, 1995, Facility Safety, U.S. Department of Energy, Washington, D.C.

DOE Order 5480.23, 1992, Nuclear Safety Analysis Reports, U.S. Department of Energy, Washington, D.C.

DOE Order 5480.28, 1993, Natura7 Phenomena Hazards Mitigation, U.S. Department of Energy, Washington, D.C.

DOE Order 5481.1B, 1986, Safety Ana7ysis and Review System (Change 1, 1987), U. S. Department of Energy, Washington, D.C.

DOE Order 6430.1A, 1989, General Design Criteria, U.S. Department of Energy, Washington, D.C.

DOE Notice 5480.5, 1992, Imposition of Nuclear Safety Requirements, (1-22-92, expires 1-22-94), U.S. Department of Energy, Washington, D.C.

DOE-STD-1020-94, 1994, Natural Phenomena Hazards Design and Evaluation Criteria for DOE Facilities, U.S. Department of Energy, Washington, D.C.

DOE-STD-1021-93, 1993, Natural Phenomena Hazards Performance Categorization Guidelines for Structures, Systems, and Components, U.S. Department of Energy, Washington, D.C.

DOE-STD-1022-94, 1994, Natural Phenomena Hazards Site Characterization Criteria, U.S. Department of Energy, Washington, D.C.

DOE-STD-1023-95, 1995, Natural Phenomena Hazards Assessment Criteria, U.S. Department of Energy, Washington, D.C.

DOE-STD-1024-92, 1992, Guidelines for Use of Probabilistic Seismic Hazard Curves at Department of Energy Sites, U.S. Department of Energy, Washington, D.C.

DOE-STD-1082-94, 1994, Preparation, Review, and Approval of Implementation Plans for Nuclear Safety Requirements, U.S. Department of Energy, Washington, D.C.

Executive Order 12699, 1990, "Seismic Safety of Federal and Federally Assisted or Regulated New Building Construction," the White House, Washington, D.C.

Executive Order 12941, 1994, "Seismic Safety of Existing Federally Owned or Leased Buildings," the White House, Washington, D.C. 
Hanford Plant Standards, Standard Design Criteria 4.1 Rev. 11, 1994, "Design Loads," U.S. Department of Energy, Richland Operations Office, Richland, Washington.

ICSSC RP-3, 1989, "Guidelines for Identification and Mitigation of Seismically Hazardous Existing Federal Buildings, "Interagency Committee On Seismic Safety in Construction, Gaithersburg, Maryland.

ICSSC RP-4, 1994, "Standards of Seismic Safety for Existing Federally Owned or Leased Buildings," Interagency Committee on Seismic Safety in

Construction, Gaithersburg, Maryland.

ICSSC RP-5, 1989, "ICSSC Guidance on Implementing Executive Order 12941 on Seismic Safety of Existing Federally Owned and Leased Buildings," Interagency Committee On Seismic Safety in Construction, Gaithersburg, Maryland.

ICSSC TR-17, 1995, How to Suggestions for Implementing Executive Order 12941 on Seismic Safety of Existing Federal Buildings, A Handbook, Interagency Committee On Seismic Safety in Construction, Gaithersburg, Maryland.

SEN-35-91, 1991, Nuclear Safety Policy, Secretary of Energy, U.S. Department of Energy, Washington, D.C.

UBC, Uniform Building Code, International Conference of Building Officials, Whittier, California.

UCRL-15910, 1990, Design and Evaluation Guidelines for DOE Facilities Subjected to Natural Phenomena Hazards (superseded by DOE Order 5480.280, University of California Lawrence Radiation Laboratory, Livermore, California.

WHC-CM-4-46, Nonreactor Facility Safety Analysis Manual, Westinghouse Hanford Company, Richland, Washington.

\subsection{OTHER REFERENCES}

Applied Technology Council, 1988, Rapid Visual Screening of Buildings for Potential Seismic Hazards, (ATC-21, also issued by the Federal Emergency Management Agency as FEMA 154, July 1988), App 7 ied Technology Council, Redwood City, California.

Busche, D. M., 1995, WHC Safety Analysis Reports and Technica7 Safety Requirements Upgrade Program, WHC-SP-1164, Westinghouse Hanford Company, Richland, Washington.

Conrads, T. J., 1995, Prioritization of Natural Phenomena Hazards Evaluations for U.S. Department of Energy Facilities, (WHC Ltr 9650233, January 16, 1995) Westinghouse Hanford Company, Richland, Washington.

Conrads, T. J., 1996a, Guidelines for Assessing the Seismic Adequacy of Existing Performance Category Equipment at the Hanford Site, WHC-SD-GN-DGS-30006 Rev. 1, Westinghouse Hanford Company, Richland, Washington. 
Conrads, T. J., 1996b, Implementation Plan for DOE Order 5480.28, Natural Phenomena Hazards Mitigation" WHC-SP-1175 Rev. 0, Westinghouse Hanford Company, Richland, Washington.

Conrads, T. J., 1996c, Procedure for Prioritization for Natural Phenomena Hazards Evaluations of Existing DOE Facilities, WHC-SD-GN-ER-30037 Rev. 0, Westinghouse Hanford Company, Richiand, Washington.

Conrads, T. J., 1996d, Volcanic Ashfall Loads for the Hanford Site, WHC-SD-GN-ER-30038 Rev. 0, West inghouse Hanford Company, Richland, Washington.

Conrads, T. J., 1997a, Engineering Design and Evaluation (when issued), HNF-PR0-97 Rev. 0, Fluor Daniel Hanford, Richland, Washington.

Conrads, T.J., 1997b, PHMC Post-NPH Emergency Response Training, HNF-SD-GN-ER-505, F1uor Daniel Hanford, Richland, Washington.

Kellogg, A. W., 1996, Implementation of the U.S. Department of Energy (DOE) Order 5480.28, Natura7 Phenomena Hazards Mitigation, (D0E Ltr 96-PR0-118, May 6, 1996) U.S. Department of Energy, Richland Operations Office, Richland, Wastington.

Knol1, J. M., 1993, DOE 5480.28, Natural Phenomena Hazards Mitigation, WHC Ltr 9358712, Westinghouse Hanford Company, Richland, Washington.

Knol1, J. M., 1996a, Implementation of the U.S. Department of Energy (DOE) Order 5480.28, Natural Phenomena Hazards Mitigation (WHC Ltr 9556559, January 3, 1996), Westinghouse Hanford Company, Richland, Washington.

Knol1, J. M., 1996b, Implementation of the U.S. Department of Energy (DOE) order 5480.28, Natural Phenomena Hazards Mitigation (WHC Ltr 9601127 R1, June 13, 1996), Westinghouse Hanford Company, Richl and, Washington.

Reidel, S. P. and Moore, C. J., 1996, Hanford Site Seismic Monitoring Instrumentation P7an, WHC-SD-GN-ER-30036 Rev. 0, Westinghouse Hanford Company, Richland, Washington.

Reide1, S. P., 1997, Letter Report, The Hanford Seismic Monitoring System, Pacific Northwest NationaT Laboratory, Richland, Washington.

Reide1, S. P., A.C. Rohay, and D.C. Hartshorn, 1997a, Hanford Strong Motion Accelerometer Network: A Summary of the First Month of Operation, HNF-SD-GN-ER-508, Fluor Daniel Hanford, Inc., Richland, Washington.

Ruben, M. S., 1996, Design Loads for Facilities, GC-LOAD-01, ICF Kaiser Hanford Company, Richland, Washington.

Ta11man, A. M., 1996a, Natura7 Phenomena Hazards, Hanford Site, South-Central Washington, WHC-SD-GN-ER-501 Rev. 0, Westinghouse Hanford Company, Richland, Washington.

Tallman, A. M., 1996b, Probabilistic Seismic Hazard Analyses, DOE Hanford Site, Washington, WHC-SD-W236A-TI-002 Rev. 1, Westinghouse Hanford Company, Richland, Washington. 
Veitenheimer, S. J., 1996, Contract No. DE-AC06-96RL13200-Contractor Plan for Implementation of DOE Order 5480.28, Natural Phenomena Hazards Mitigation, (Letter No. 96-PMDB-081 to H. J. Hatch, Fluor Daniel Hanford, Inc.), U.S. Department of Energy, Richland Operations office, Richland, Washington.

Wagenblast, G. R., 1996a, Hanford Site Post-NPH Building Inspection Plan, WHC-SD-GN-ER-504, ICF Kaiser Hanford Company, Richland, Washington.

Wagenblast, G. R., 1996b, Procedure for Post-NPH Inspection of Buildings, WHC-SD-GN-ER-503, ICF Kaiser Hanford Company, Richland, Washington.

Webb, A. J. and Conrads, T. J., 1994, Proposed Correlation DOE Safety Classes, Performance Categories and Design Requirements, WHC-SD-GN-RD-30011, Westinghouse Hanford Company, Richland, Washington.

Whalen, C. L., 1997, Inventory Phase of Executive Order No. 12941, Seismic Safety of Existing Federally Owned or Leased.Buildings, FDH-9751745A R1, Fluor Daniel Hanford, Richland, Washington.

Wise, G. M., 1994, New Facility/SSC Interpretation for DOE Order 5480.28 , (WHC Ltr 9455108 R1, October 18, 1994), Westinghouse Hanford Company, Richland, Washington.

Wise, G. M., 1996, Implementation of U.S. Department of Energy (DOE) 5480.28 Natural Phenomena Hazards Mitigation, (WHC Ltr 9653887, September 1996), Westinghouse Hanford Company, Richland, Washington. 


\section{HNF-SP-1175}

\section{APPENDIX A}

COMPLIANCE BASELINE FOR NEW AND EXISTING

BUILDINGS AND STRUCTURES IN COMPLIANCE

WITH DOE ORDER 5480.28 
HNF-SP-1175

This page intentiona17y left blank. 
APPENDIX A. COMPLIANCE BASELINE FOR NEW AND EXISTING BUILDINGS AND STRUCTURES IN COMPLIANCE WITH DOE ORDER 5480.28. TOTAL ASSETS $=326$

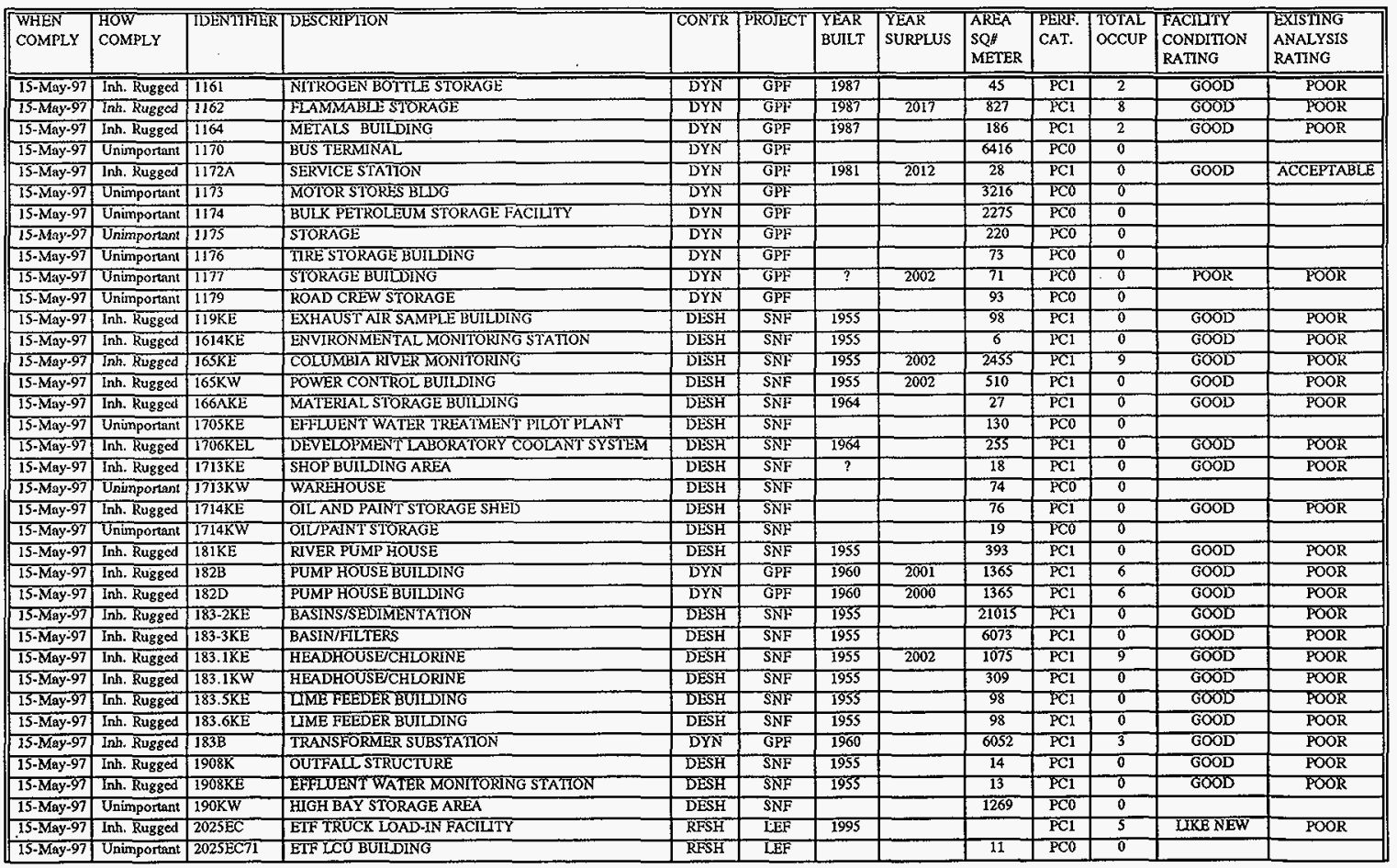




\begin{tabular}{|c|c|c|c|c|c|c|c|c|c|c|c|c|}
\hline $\begin{array}{l}\text { WHEN } \\
\text { COMPLY }\end{array}$ & $\begin{array}{l}\text { HOW } \\
\text { COMPLY }\end{array}$ & TIDENTMFER & DESCRTPTON & CONTR & PROJECT & $\begin{array}{l}\text { YEART } \\
\text { BUILT }\end{array}$ & $\begin{array}{l}\text { YEAR } \\
\text { SURPLUS }\end{array}$ & \begin{tabular}{|l}
$A \overline{R E A}$ \\
$S Q \#$ \\
METER
\end{tabular} & $\begin{array}{l}\text { PERFF. } \\
\text { CAT. }\end{array}$ & TOTAL & $\begin{array}{l}\text { FACIIITY } \\
\text { CONDITION } \\
\text { RATING }\end{array}$ & $\begin{array}{l}\text { ERISTING } \\
\text { ANALYSIS } \\
\text { RATING }\end{array}$ \\
\hline 15-May-97 & Unimportant & $203 \mathrm{~A}$ & ACID PUMP HOUSE & $\overline{\mathrm{BWHAT}}$ & PUTEX & & & 74 & $\mathrm{PCO}$ & 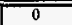 & & \\
\hline 15-May-92 & Uninportant & $204 \mathrm{~A}$ & U CELL BELOW GRADE ACID RECOVERY VAULT & BWHC & PUREX & & & 150 & PCO & 0 & & \\
\hline 15-May-97 & Uninportant & $205 \AA$ & SILCA GEL TREATMENT FACIUTY & BWHC & PUREX & & & 8 & $\mathrm{PCO}$ & 0 & & \\
\hline 15-May-97 & Unimportant & $206 \AA$ & $\begin{array}{l}\text { ABOVE GRADE VACUUUM ACID FRACTIONATOR } \\
\text { BUKLING }\end{array}$ & BWHC & PUREX & & & 180 & $\mathrm{PCO}$ & 0 & & \\
\hline 15-May-97 & Unimportant & $211 \mathrm{~A}$ & PUMP HOUSE - CHIEMICAL MAKE UP & BWHC & PUTREX & & & 313 & PCO & 0 & & \\
\hline 15-May-97 & Uninportant & $211 \mathrm{~B}$ & COLD CHEMICAL MAKE UP TANK FARM & BWHC & B.PLANT & & & 14 & PCO & 0 & & \\
\hline 15-May-97 & Inh. Rugged & 211BA & BCE NEUTRALUATTON TANK & BWHAC & B-PLANT & 1990 & & 94 & $\mathrm{PCl}$ & 0 & 6000 & POOR \\
\hline 15-May-97) & Unimporant & 211313 & MOTOR CONTROL CENTER & BWHC & B-PLANI' & & & 3 & PCO & 0 & & \\
\hline 15-May-97 & Unimportant & $211 \mathrm{~T} 52$ & 21ITINSTRUMENT BUILDING & RFSH & T-PLANT & 1955 & & 13 & $\mathrm{PCO}$ & 0 & POOR & \begin{tabular}{|l} 
ACCEEPTABLE \\
\end{tabular} \\
\hline 15-May-97 & Inh. Rugged & $2120 \mathrm{WA}$ & BUILDING CWC EQUIP STORAGE & RFSH & CWC & 1996 & 2005 & 374 & $\mathrm{PCI}$ & 0 & UKE NEW & MARGINAL \\
\hline 15-May-97 & Inh. Rugged & $2120 \mathrm{WB}$ & BUILDING CWC EQUIP STORAGE & RFSH & CWC & 1996 & 2005 & 374 & $\mathrm{PCl}$ & $\mathbf{0}$ & LKE NEW & MARGINAL \\
\hline 15-May-97 & Tuninportant & $212 \pi$ & FISSION PRODUCT LOAD OUT STATTON & BWHC & PUREX & & & 64 & $\mathrm{PCO}$ & 0 & & \\
\hline $15-M \mathrm{gay}-97$ & Inh. Rugged & $212 s$ & COMPRESSED GAS STORAGE BUILDING/DOCK & RFSH & $222-\mathrm{S}$ & 1990 & & 50 & $\mathrm{PC1}$ & o & $\overline{G O O D}$ & POOR \\
\hline 15-May-97 & Unimporant & $213 \mathrm{~A}$ & FSSION PRODUCT LOAD IN STATTON & BWHC & PUREX & & & 45 & $\mathrm{PCO}$ & 0 & & \\
\hline 15-May-97 & Unimporans & $213 S$ & OXYGEN GAS DOCK & RFSH & 222.5 & & & 50 & $\mathrm{PCO}$ & 0 & & \\
\hline 15-May-97 & Unimportant & $214 \mathrm{~A}$ & PUREX WAREHOUSE & BWHC & PUREX & & & 84 & $\mathrm{PCO}$ & 0 & & \\
\hline 15-May-97 & inh. Rugged & $214 \mathrm{~T}$ & METAL CHEMCCAL STORAGE BUILDING & RFSH & T.PLANT & 1987 & & 130 & $\mathrm{PCl}$ & 0 & GOOD & ACCEPTABLE \\
\hline 15-May-97 & Unimportant & $216 \mathrm{A42}$ & RETENTION BASIN & BWHC & PUREX & & & 959 & $\mathrm{PCO}$ & 0 & & \\
\hline $15 \cdot$ May-97 & Unimportant & $216 \mathrm{~B} 13$ & FRENCH DRAINS & BWHC & B.PLANT & & & & $P C O$ & 0 & & \\
\hline 15-May-97 & Unimporant & $216 \mathrm{BA}$ & REVERSE WELIS & BWHC & B.PLANT & & & & $\mathrm{PCO}$ & 0 & & \\
\hline 15-May-97 & Unimportant & $216 \mathrm{BS9}$ & CRIB AND TILE FELD RETENTION BASIN & BWHC & B.PIANT & & & & $\mathrm{PCO}$ & 0 & & \\
\hline 15-May-97 & Unimporlanl & $216 \mathrm{~B} 60$ & CRIB AND TILE FELLD & \begin{tabular}{|l|} 
BWHC \\
\end{tabular} & B-PLANT & & & & $\mathrm{PCO}$ & 0 & & \\
\hline 15-May-97 & Unimportant & $217 \mathrm{~B}$ & \begin{tabular}{|l} 
WATER TREATMENT BUILDING \\
\end{tabular} & \begin{tabular}{|l|} 
BWHC \\
\end{tabular} & B.PLANT & & & 44 & PCO & 0 & & \\
\hline $15-2 M a y-97$ & Unimporan1 & $2213 E$ & FOKK LHT STOKAGE BUIDING & $\begin{array}{ll}\text { BWHAC } \\
\end{array}$ & B-PLANT & & & 11 & PCO & 0 & & \\
\hline 15-May-97 & Unimpontant & $221 \mathrm{BF}$ & $\begin{array}{l}\text { CONDENSATE EFFLUENT DISCHARGE FACIUTY, } \\
\text { BCP STORAGE PIT }\end{array}$ & BWHC & B.PLANT & & & 66 & $\mathrm{PCO}$ & $\overline{0}$ & & \\
\hline 15-May-97 & Unimportant & $221 \mathrm{BG}$ & B PLANT COOING WATER MONITORING BUILDING & BWHC & B.PLANT & & & 6 & $\mathrm{FCO}$ & 0 & & \\
\hline 15-May-97 & Unimportant & 2211\% & VENT FAN HOUSE & RFSH & T-PLANT & & & 140 & $\mathrm{PCO}$ & 0 & & \\
\hline 15-May-97 & Unimportant & 22173 & T PLANT CANYON LAUNDDRY STORAGE & $\mathrm{RFSH}$ & T.PLANT & & & & $\mathrm{PCO}$ & 0 & & \\
\hline 15-May-97 & Inh. Rugged & $2225 \mathrm{SE}$ & 222SE FILTER BLDG. & RFSH & $222-S$ & 1994 & 2027 & 46 & $\mathrm{PCl}$ & 0 & LKE NEW & $\overline{P O O R}$ \\
\hline 15-May-97 & Int. Rugged & $222 \mathrm{SH}$ & KELCY BUILDING & RFSH & $222-\mathrm{S}$ & 1990 & & 100 & $\mathrm{PC1}$ & 5 & GOOD & POOR \\
\hline 15-May-97 & Wunimportant & $222 \pi$ & TOFFCE ADMMISTRATIONBUILDING & DYN & $\overline{G P F}$ & & & 699 & $\mathrm{PCO}$ & 0 & & \\
\hline 15-May-97 & Unimportant & $222 \mathrm{U}$ & OFFCE AND LABORATORY BÜILDING & DYY & GPF & & & 698 & $\mathrm{PCO}$ & 0 & & \\
\hline 15-May-97 & Inh. Rugged & $225 \mathrm{E}$ & PUMP STATTON NO. 2 \& LOCAL CNTRLUNTT 5SC-10 & RFSH & LEF & 1994 & 2025 & 84 & $\mathrm{PC1}$ & 5 & UKE NEW & POOR \\
\hline \begin{tabular}{|l|}
$15-$ May-97 \\
\end{tabular} & Inh. Rugged & $225 \mathrm{~W}$ & PUMP STATON NO. 1 \& LOCAL CNTRL UNIT $55 \mathrm{C}-20$ & RFSH & LEF & 1994 & 2025 & 84 & PC1 & 5 & UKKE NEW & POOR \\
\hline 15-May-97 & Tnh. Kugged & $225 \mathrm{WB}$ & LOCALCNTRL UNIT SSC-22 & RESH & $222-s$ & 1994 & & 20 & PC1 & 0 & LUKE NEW & POOR \\
\hline 15-May-97 & Inh. Rugged & $225 \mathrm{WC}$ & $\begin{array}{l}\text { INSTRUMENTATION \& LOCAL CONTROL UNIT } \\
55 \mathrm{C}-23\end{array}$ & BWHC & PFP & 1993 & 2007 & 10 & 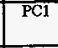 & 9 & LIKE NEW & $\overline{P O O R}$ \\
\hline 15-May-97 & Unimportant & $234 \mathrm{ZC}$ & STORAGE BUILDING & BWHC & PFP & & & 10 & $\mathrm{PCO}$ & 0 & & \\
\hline
\end{tabular}









\begin{tabular}{|c|c|c|c|c|c|c|c|c|c|c|c|c|}
\hline $\begin{array}{l}\text { WHEN } \\
\text { COMPLY }\end{array}$ & COMPLY & TDENTIFIER & DESCRIPTION & CONTR & PROJECT & $\begin{array}{l}\text { YEAR } \\
\text { BUILT }\end{array}$ & $\begin{array}{l}\text { YEAR } \\
\text { SURPLUS }\end{array}$ & \begin{tabular}{|l|} 
AREA \\
SQ\#"' \\
METER \\
\end{tabular} & $\begin{array}{l}\text { PERF. } \\
\text { CAT. }\end{array}$ & $\begin{array}{l}\text { TOTAL } \\
\text { OCCUP }\end{array}$ & $\begin{array}{l}\text { FACILITY } \\
\text { CONDIMION } \\
\text { RATING }\end{array}$ & $\begin{array}{l}\text { EXISTING } \\
\text { ANALYSIS } \\
\text { RATING }\end{array}$ \\
\hline 15.May-97 & Unimportant & $2716 \mathrm{~B}$ & $\begin{array}{l}\text { RM CHECKOUT STATON, NEAR TUNNELCHANGE } \\
\text { BUILDING }\end{array}$ & BWHC & B-PLANT & & & 20 & $\overline{\mathrm{PCO}}$ & $\overline{\overline{0}}$ & & \\
\hline 15-May-97 & Unimportant & $2716 \mathrm{~T}$ & RM CHECK OUT STATION NEAR TUNNEL & RFSH $^{-1}$ & T-PLANT & 1995 & & 6 & $\mathrm{PCO}$ & 0 & DKE NEW & ACCEPTABLE \\
\hline 15-May-97 & Unimportant & $2719 \mathrm{E}$ & OFFCE MACCHINE STORAGE & DYN & GPF & & & 77 & $\mathrm{PCO}$ & 0 & & \\
\hline 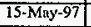 & Unimportant & $2719 \mathrm{WA}$ & FIRST AID STATION AND OFHCES & DYN & GPF & & & 237 & $\mathrm{PCO}$ & 0 & & \\
\hline 15-May-97 & Inh. Rugged & $2719 \mathrm{WB}$ & MODULAR FIRST AID STATTON & DYN & GPF & 1995 & 2027 & 172 & PCI & 4 & UKENEW & POOR \\
\hline 15-May-97 & Unimportant & $271 \mathrm{AB}$ & PUREX MAINTENANCE SUPPORT FACIUTY & BWHC & PUREX & & & 520 & PCO & 0 & & \\
\hline 15-May-97 & Unimportant & $271 B A$ & LAUNDRY STORAGE BLDG. NORTH OF $271 \mathrm{~B}$ & BWHC & B-PLANT & & & 31 & PCO & 0 & & \\
\hline 15-May-97 & Unimportant & $2720 \mathrm{~W}$ & SRT PATROL HQ/CHANGE ROOM & DYN & GPF & & & 206 & $\mathrm{PCO}$ & $\overline{0}$ & & \\
\hline 15-May-97| & Unimporant & $2722 \mathrm{E}$ & OHFCE BULLDING & DYN & GPF & & & 112 & PCO & 0 & & \\
\hline 15-May-97 & Unimportant & $2722 \mathrm{~W}$ & WELDING IABORATORY BUILDING & DYN & GPF & & & 140 & $\mathrm{PCO}$ & 0 & & \\
\hline 15-May-97| & Unimportant & 27222 & TRUCK LOADOUT STATION & BWHC & PEP & & & & $\mathrm{PCO}$ & 0 & & \\
\hline \begin{tabular}{|l|l|}
$15-$ May-97 \\
\end{tabular} & Unimportant & $2724 \mathrm{WM3}$ & LAUNDKY STORAGE BUILDING & DYN: & GPF & & & 148 & PCO & 0 & & \\
\hline 15-May-97| & Unimporant & $272 \mathrm{E}$ & FABRKCAMON, MOCKUYP SHOP BUILDING & DYN & GPF & & & $\overline{1724}$ & $\mathrm{PCO}$ & 0 & & \\
\hline 15-May-97 & Unimportant & $2734 Z$ & GAS CYINDER STORAGE BUILDHNG & BWHC & PFP & & & 150 & $\overline{P C 0}$ & 0 & & \\
\hline 15-May-97 & Unimportant & 2734ZL & $\begin{array}{l}\text { HYDROGEN FLUOKIDE FACIUTYY PLATFOKM } \\
\text { SCALE }\end{array}$ & BWHC & PFP & & & 10 & PC0 & 0 & & \\
\hline 15-May-97 & Unimportant & $2735 \mathrm{Z}$ & CHEMICALSTORAGE & BWHC & PFP & & & 150 & FCO & 0 & & \\
\hline 15-May-97 & Unimportant & $273 \mathrm{E}$ & STORAGE BUILDING & DYN & GPF & & & 558 & PCO & 0 & & \\
\hline 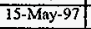 & Inh. Rugged & $273 W$ & STORAGE BUILDING & DYN & GPF & 1987 & 2017 & 557 & $\mathrm{PCl}$ & 0 & GOOD & POOR \\
\hline 15-May-97 & Unimportant & $274 \mathrm{~W}$ & OFFCE BUILDING & DYN & $\overline{G P F}$ & & & 355 & PCO & $\overline{0}$ & & \\
\hline 15-May-97| & Unimportant & 275EA & WAREHOUSE BUILDING & DYN & GPF & & & 3344 & PCO & 0 & & \\
\hline 15-May-97 & Unimportant & $276 \mathrm{~A}$ & $\begin{array}{l}\text { COLD SOLVENT STORAGE BUILDING, RCELL } \\
\text { VAULT }\end{array}$ & BWHC & PUREX & & & 320 & $\mathrm{PCO}$ & $\overline{0}$ & & \\
\hline 15-May-97 & Unimportant & $276 \mathrm{~B}$ & COLD SOLVENT STORAGE BUILDING & BWHC & B-PLANT & & & 53 & PCO & 0 & & \\
\hline 15-May-97 & Unimportant & $276 \mathrm{C}$ & SOLVENT HANDLNNG BUILDING & DYN & GPF & & & 214 & $\mathrm{PCO}$ & 0 & & \\
\hline 15-May-97 & Inh. Rugged & $278 \mathrm{WA}$ & TANK FARM DOCUMENT CONTROL CENTER & DYN & GPF & 1993 & 2012 & 172 & $\mathrm{PC} 1$ & 9 & UKE NEW & POOR \\
\hline 15-May-97| & Unimportant & $281 \mathrm{~A}$ & BACKUP GENERATOR FACIUTYY & BWHC & PUREX & & & 18 & PCO & 0 & & \\
\hline $\begin{array}{ll}5-M a y-97 \\
\end{array}$ & Inh. Kugged & $282 \mathrm{E}$ & $\begin{array}{l}\text { PUMP HOUSE AND RESERVOIR PUMP HOUSE AND } \\
\text { RESERVOIR }\end{array}$ & DYN & GPF & 1960 & & 133 & PC1 & 0 & GOOD & POOR \\
\hline 15-May-97 & \begin{tabular}{|l|} 
Inh. Rugged \\
\end{tabular} & 282EA & WATER RESERVOIR INLET HOUSE, NORTH & DYN & GPF & 1960 & & 16 & $\mathrm{PCl}$ & 0 & GOOD & POOR \\
\hline 15-May-9? & \begin{tabular}{|l|} 
Inh. Kugged \\
\end{tabular} & $282 \mathrm{~EB}$ & WATER RESERVOIR INLET HOUSE, SOUTH & DYN & GPF & 1960 & & 20 & $\mathrm{PC1}$ & 0 & GOOD & POOR \\
\hline I5-May-97| & Inth. Rugged & $282 \mathrm{~W}$ & RESERVOIR PUMP HOUSE & DYN & GPF & 1960 & & 133 & $\mathrm{PC1}$ & 0 & GOOD & POOR \\
\hline 15-May-97 & Inh. Rugged & $282 \mathrm{WA}$ & WATER INLET HOUSE & DYN & GPF & 1960 & & 16 & PCI & 0 & GOOD & POOR \\
\hline 15-May-97 & Inh. Rugged & $283 \mathrm{WD}$ & RECYCLE PUMP STATTON & DYN & GPF & 1990 & & 20 & $\mathrm{PC1}$ & $\overline{0}$ & LKKE NEW & POOR \\
\hline 15-May-97 & Inth. Rugged & $283 \mathrm{WF}$ & SAMPLE BUILDING & DYN & GPF & 1990 & & 16 & PC1 & $\overline{0}$ & LKE NEW & POOR \\
\hline 15-May-97 & Unimportant & $284 \mathrm{~W}$ & STEAM PLANT & DYN & GPF & & & 25205 & $\mathrm{PCO}$ & 0 & & \\
\hline 15-May-97| & Unimportant & $2901 \mathrm{~A}$ & WATER STORAGE TANKS AND UNES, $30,000 \mathrm{GAL}$ & BWAC & PUREX & & & & PCO & $\sigma$ & & \\
\hline 15-May-97 & Unimportant & $2902 Z$ & $\begin{array}{l}\text { ELEVATED WATER STORAGE TOWER AND TANK } \\
50000 \text { GAL }\end{array}$ & BWHC & PFP & & & & $\mathrm{PCO}$ & 0 & & \\
\hline 15-May-97 & Unimportant & $2904 \mathrm{EA}$ & CHEMICALSEWER SAMPLNG BLDG.,NO. OF 221B & BWHC & B-PLANT & & & 5 & $\mathrm{PCO}$ & 0 & & \\
\hline
\end{tabular}




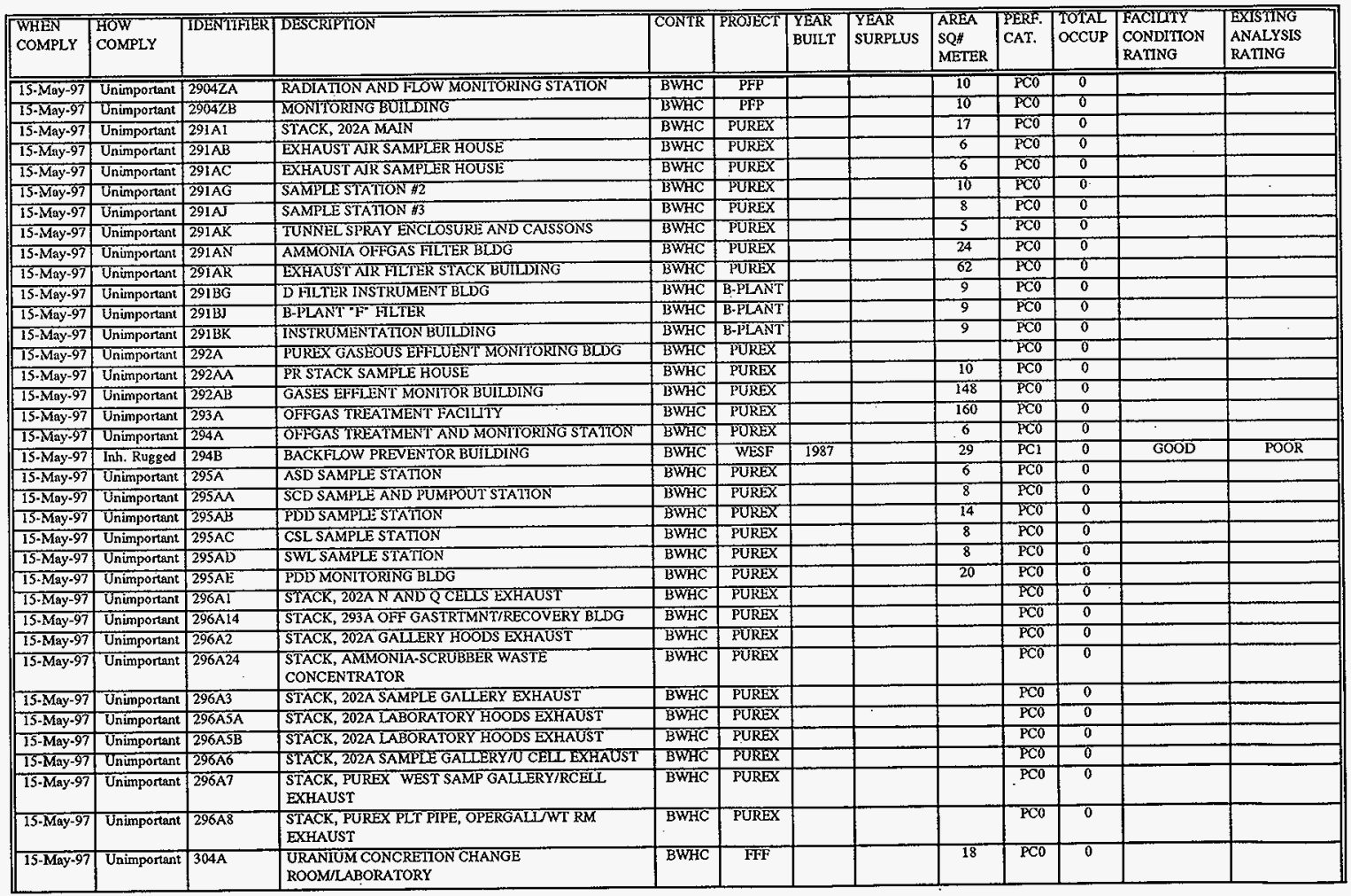


HNF-SP-1175

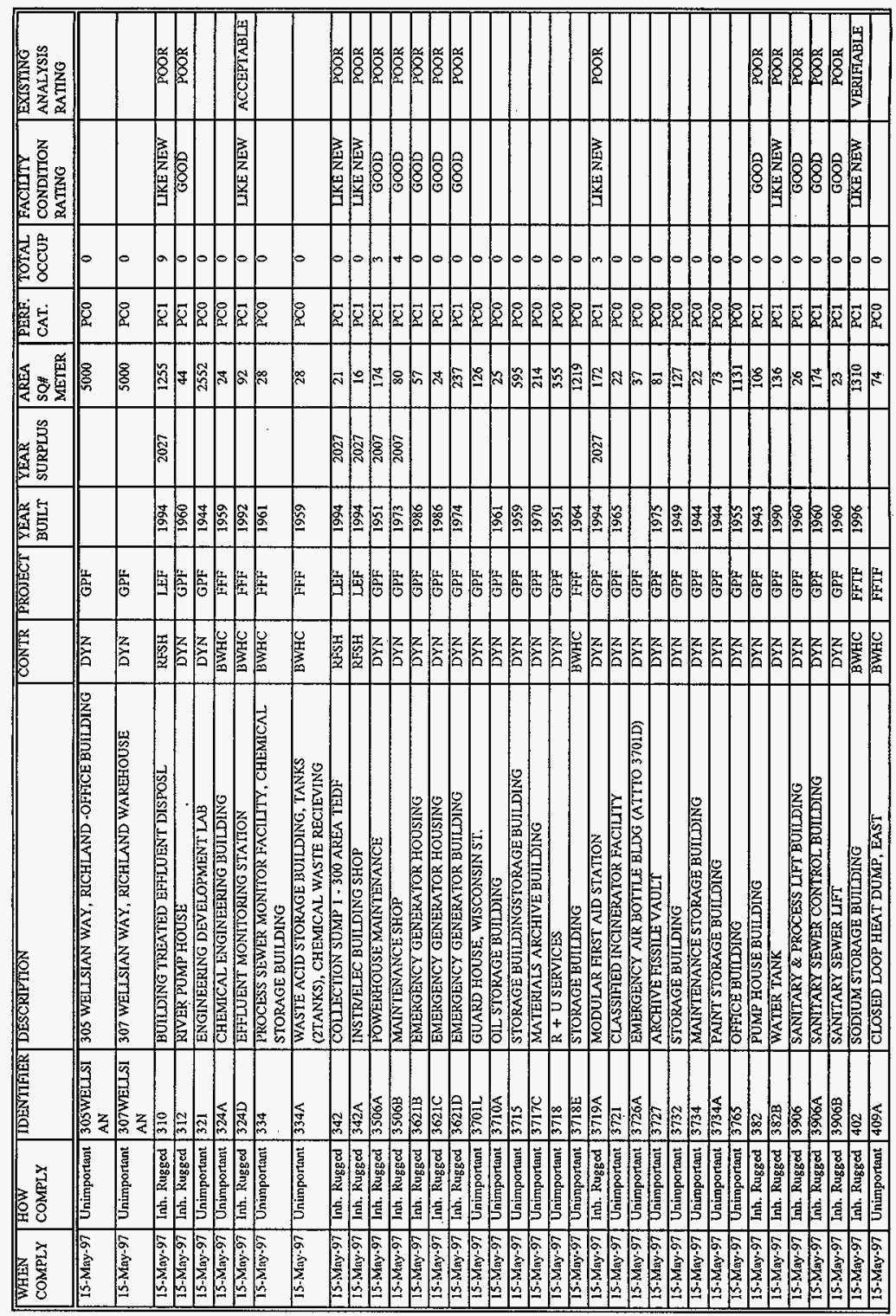




\begin{tabular}{|c|c|c|c|c|c|c|c|c|c|c|c|c|}
\hline $\begin{array}{l}\text { WHEN } \\
\text { COMPLY }\end{array}$ & $\begin{array}{l}\text { HOW } \\
\text { COMPLY }\end{array}$ & DDENTTFER & DESCRIPITON & CONTR & PROIECT & $\begin{array}{l}\text { YEAR } \\
\text { BUILT }\end{array}$ & $\begin{array}{l}\text { YEAR } \\
\text { SURPLUS }\end{array}$ & \begin{tabular}{|l|} 
AREA \\
SQH \\
METER \\
\end{tabular} & $\begin{array}{l}\text { PERFF. } \\
\text { CAT. }\end{array}$ & $\begin{array}{l}\text { TOTAL } \\
\text { OCCUP }\end{array}$ & $\begin{array}{l}\text { FACILITY } \\
\text { CONDITION } \\
\text { RATING } \\
\end{array}$ & $\begin{array}{l}\text { EXISTING } \\
\text { ANALYSIS } \\
\text { RATING } \\
\end{array}$ \\
\hline 15-May-97| & Unimportant & $409 \mathrm{~B}$ & CLOSED LOOP HEAT DUMP, EAST & BWHC & FFTF & & & 74 & PCO & $\mathbf{0}$ & & \\
\hline 15-May-97 & Inh. Rugged & 427 & FUELS \& MATERIAL EXAMINATIONFACIUTYYFMEF & BWHC & FFF & 1984 & 2037 & 15794 & FC1 & 4 & GOOD & VERIFABLLE \\
\hline 15-May-97 & \begin{tabular}{|l|} 
Unimportant \\
\end{tabular} & $432 A$ & GAS BOTTLE STORAGE & BWHC & FFTF & & & 93 & $\overline{\mathrm{PCO}}$ & $\mathbf{0}$ & & \\
\hline $15 \cdot$ May:97 & Unimportant & $4701 \mathrm{~A}$ & FORMER GUARD STATION & BWHC & FFTF & & & 134 & PCO & 0 & & \\
\hline 15-May-97 & Unimportant & $4701 \mathrm{~B}$ & $\begin{array}{l}\text { GUARD STATION, GRANT AVE.UNKNOWN } \\
\text { BUILDING }\end{array}$ & DYN & GPF & & & 59 & $\mathrm{PCO}$ & $\overline{0}$ & & \\
\hline $15 \cdot$ May-97 & Unimportant & $4704 \mathrm{~N}$ & SECURITY MAINTENANCE SHOP OFHCE BULLING & DYN & GPF & & & 744 & PCO & $\overline{0}$ & & \\
\hline 15-May-97 & Inh. Rugged & $4709 \mathrm{~A}$ & FRE STAMION, HOSE STOKAGE & DYN & $\overline{G P F}$ & 1984 & 2007 & 837 & $\mathrm{PCl}$ & 5 & GOOD & POOR \\
\hline 15-May-97 & Unimportant & 4719 & MEDICAL AID STATION & DYN & GPF & & & 171 & $\mathrm{PCO}$ & 0 & & \\
\hline 15-May-97 & Unimportant & 4726 & TANTTORIALSTORAGE & BWHC & FFTF & & & 30 & PCO & 0 & & \\
\hline 15-May-97 & \begin{tabular}{|l|} 
Unimportant \\
\end{tabular} & 473213 & WAREHOUSE & BWHC & FFTF & & & 2230 & $\mathrm{PCO}$ & 0 & & \\
\hline 15-May-97 & Unimportant & $4732 \mathrm{C}$ & WAREHOUSE & BWHC & FFTF & & & 1859 & PCO & 0 & & \\
\hline 15-May-97 & Unimportant & $4734 \mathrm{C}$ & WAREHHOUSE (SPECIAL TOOLS) STORAGE BUILDING & DYN & GPF & & & 735 & $\mathrm{PCO}$ & 0 & & \\
\hline 15-May-97 & Unimportant & $4734 \mathrm{D}$ & WAREHOUSE & DYN & $\overline{\mathrm{GPF}}$. & & & 735 & PCO & 0 & & \\
\hline 15-May-97 & \begin{tabular}{|l|} 
Unimportant \\
\end{tabular} & $4842 \mathrm{~B}$ & SWITCH WATER PUMPHOUSEWATER PUMP HOUSE & BWHC & FFTF & & & 28 & PCO & 0 & & \\
\hline 15-May-97 & Unimportant & 4843 & ALKALA METAL STORAGE & BWHC & FFTF & & & 150 & $\overline{P C O}$ & 0 & & \\
\hline 15-May-97 & Inh. Kugged & $604 \mathrm{~A}$ & YAKIMA BARRICADE, PATROL SENTRY & DYN & GPF & 1985 & 2017 & 22 & PC1 & 1 & 6000 & POOR \\
\hline 15-May-97 & Unimportant & $604 \mathrm{G}$ & WYE BARRICADE, PATROL UTILITY BUILDING & DYN & GPF & & & 9 & $\mathrm{PCO}$ & 0 & & \\
\hline 15-May-97 & Unimportant & 6265 & $\begin{array}{l}\text { ENVIRONMENTAL SUPPOKT LABORATORY UTILITY } \\
\text { BLDG }\end{array}$ & RFSH & HAS & 1993 & 2024 & 335 & $\mathrm{PCO}$ & 0 & UKE NEW & MARGINAL \\
\hline 15-May-97 & \begin{tabular}{|l|} 
Unimportant \\
\end{tabular} & $6265 \mathrm{~A}$ & SOLD WASTE STORAGE BUILDING & RFSH & HAS & 1993 & 2024 & 67 & PCO & 0 & TIKENEW & POOR \\
\hline 15-May-97 & Unimportant & $6266 \mathrm{~A}$ & $\begin{array}{l}\text { CONTAMMINATED LIQUID WASTE RETENTION } \\
\text { VAULT }\end{array}$ & RFSH & HAS & 1993 & 2024 & 67 & PCO & 0 & LIKE NEW & VERIFED \\
\hline 15-May-97| & Inh. Rugged & 6267 & ENVIRONMENTAL SAMPLE ARCHIVE BUILDING & RFSH & HAS & 1993 & 2024 & 167 & $\mathrm{PC1}$ & $\mathbf{0}$ & LIKE NEW & MARGINAL \\
\hline 15-May-97 & Inth. Kugged & 6268 & SAMPLE EQUPMENT CLEANINO (future) & RFSH & HAS & 1995 & 2026 & 223 & PC1 & 4 & ZIRENEW & ACCEPTABLE \\
\hline 15-May-97 & \begin{tabular}{|l|} 
Inth. Rugged \\
\end{tabular} & 6269 & \begin{tabular}{|l} 
MOBILE LABORATORY STORAGE \\
\end{tabular} & RFSH & HAS & 1993 & 2024 & 632 & PCI & 9 & LKE NEW & MARGINAL \\
\hline 15-May-97 & Inh. Rugged & 6653 & SAMPLE AND MONITORING BUILDING & RFSH & LEF & 1994 & 2025 & 47 & PC1 & 5 & UIKE NEW & POOR \\
\hline 15-May-97 & Inh. Rugged & 6701 & WYE BARRICADE GUARD HOUSE & $\overline{D Y N}$ & GPF & 1992 & 2027 & 24 & $\mathrm{PC1}$ & 1 & UKE NEW & POOR \\
\hline 15-May-97 & Inh. Rugged & 67018 & SR240/2WBARRICADE & DYN & GPF & 1994 & 2017 & 2 & PCI & 1 & LIKE NEW & POOR \\
\hline 15-May-97 & Unimportant & MO006 & MOBILE OFFCE (377 TRL 1) & DYN & GPF & 1974 & & 62 & $\mathrm{PCO}$ & 0 & & \\
\hline
\end{tabular}




\begin{tabular}{|c|c|c|c|c|c|c|c|c|c|c|c|c|}
\hline $\begin{array}{l}\text { WHEN } \\
\text { COMPLY }\end{array}$ & $\begin{array}{l}\text { COW } \\
\text { COMPLY }\end{array}$ & IDENTIFER & DDESCEIPTION & CONTR & PROJECT & $\begin{array}{l}\text { YEAR } \\
\text { BULLT }\end{array}$ & $\begin{array}{l}\text { YEAR } \\
\text { SURPLUS }\end{array}$ & $\begin{array}{l}\text { AREA } \\
\text { SQA } \\
\text { METER }\end{array}$ & $\begin{array}{l}\text { PERE. } \\
\text { CAT. }\end{array}$ & $\begin{array}{l}\text { TOTAL } \\
\text { OCCUP }\end{array}$ & $\begin{array}{l}\text { FACIITY } \\
\text { CONDITONON } \\
\text { RATING }\end{array}$ & $\begin{array}{l}\text { EXISTING } \\
\text { ANALYSIS } \\
\text { RATING }\end{array}$ \\
\hline 15-May-97 & Unimportant & MOÖ1 & MOBILE OFFICE (323 TRL 2$)$ & $\overline{\text { DYN }}$ & GPF & 1981 & & 172 & $\overline{\mathrm{PCO}}$ & 0 & & \\
\hline 15-May.97) & Unimportant & MO056 & MOBILE OHFICE @ 2704W & DYN & GPF & & & 147 & PCO & $\bar{\sigma}$ & & \\
\hline $15-$ May 97 & Unimportant & MO215 & MOBILE OFFCE \& 2704W & DYN & GPF & & 2002 & 62 & $\mathrm{PCO}$ & $\overline{0}$ & & \\
\hline 15-May-97 & Unimporant & MO221 & MOBILE OFFCE $12704 \mathrm{~W}$ & DYN & GPF & & & 62 & $\mathrm{PCO}$ & 0 & & \\
\hline 15-May-97 & Inh. Rugged & MO235 & MOBILE OFFICE (2722W) & DYN & GPF & 1986 & 2017 & 171 & $\mathrm{PCl}$ & $\mathrm{l}$ & GOOD & POOR \\
\hline 15-May-97 & Inh. Ruggod & MO240 & MOBILE OHFCE (284W) & DYN & GPF & 1986 & 2017 & 171 & PCI & 1 & GOOD & POOR \\
\hline 15-May-97 & Inl. Rugged & MO244 & 200W PATROL CHANGE TRALLER @234-SZ & DYN & GPF & 1990 & 2017 & 258 & $\mathrm{PCl}$ & 0 & GOOD & POOR \\
\hline 15-May-97 & Inh. Rugged & MO245 & MOBILE OFFICE - TRAILER GATE 815 & DYN & GPF & 1990 & 2007 & 172 & PCI & 8 & GOOD & POOR \\
\hline 15-May-97 & Inh. Kugged & MO246 & MOBILE OHFCE - TRAILER GATE 815 & DYN & $\overline{G P F}$ & 1990 & 2007 & 172 & $\mathrm{PCI}$ & 9 & GOOD & POOR \\
\hline 15-May-97 & Inh. Rugged & MO248 & MOBILE OFHCE - TRAILER GATE 815 & DYN & OPF & 1990 & 2007 & 172 & PCI & 9 & GOOD & POOR \\
\hline 15-May-97 & Inh. Rugged & MO249 & MOBILE OFFCE @ 234-5Z (OUTSIDE FENCE) & DYN & GPF & 1990 & 2007 & 172 & $\overline{\mathrm{PCI}}$ & 8 & GOOD & POOR \\
\hline 15-May-97 & Inh. Rugged & MO252 & MOBILE OFFICE, - TRAILEK GATE 850 & DYN & GPF & 1990 & 2007 & 172 & PCI & 0 & GOOD & POOR \\
\hline $15-$ May-97 & Inh. Rugged & MO253 & MOBILE OFFCE, - TRAILER GATE 850 & $\overline{D Y N}$ & GPF & 1990 & 2007 & 172 & PCI & 7 & GOOD & POOR \\
\hline 13-May-97 & Unimportant & MO260 & MOBILE OFFCE @ BMT & DYN & GPF & 1990 & & 172 & PCO & 0 & & \\
\hline 15-May-97 & Unimportant & MO251 & MOBILE OFICE @ $\triangle$ FMT & DYN & GPF & 1990 & & 172 & $\mathrm{PCO}$ & 0 & & \\
\hline 15-May-97 & Inh. Rugged & MO269 & $\begin{array}{l}\text { CHANGE TRALER } E O \text { SUB } \\
\text { BURIALGROUNDMOBILE SUB BURIAL SITE }\end{array}$ & RFSH & LEF & 1991 & & 172 & PCI & 5 & UKE NEW & POOR \\
\hline 15:May-97 & Unimportant & MO274 & MOBLLE OFFICE (3242T) & BWHC & FFF & 1992 & & 170 & $\mathrm{PCO}$ & $a^{\circ}$ & & \\
\hline 15-May-97 & Inh. Rugged & MO288 & $\begin{array}{l}\text { MOBILE CHANGE FACLLTYY O CTRLWASTE } \\
\text { COMPLEX }\end{array}$ & RFSH & SWM & 1994 & & 36 & PCI & 9 & UIKE NEW & MARGINAL \\
\hline 15-May-97 & Inh. Rugged & MO289 & MOBILE CHANGE FACIUTY (O) 224T & RFSH & SWM & 1994 & & 36 & $\overline{\mathrm{PCI}}$ & 9 & DKE NEW & MARGINAL \\
\hline 15-May-97 & Unimportant & M0306 & MOBILEOFFCE $222 T$ & DYN & GPF & & & 62 & $\mathrm{PCO}$ & 0 & & \\
\hline 15-May-97 & Unimportant & MO315 & MOB̈ILE CHANGE TRAILER & DYN & GPF & & & 52 & $\mathrm{PCO}$ & 0 & & \\
\hline \begin{tabular}{|l|l|}
$15-\bar{M}$ May-97 \\
\end{tabular} & Unimportant & MO322 & SWP CHANGE TRAILER Q 207B & BWHC & \begin{tabular}{|l|} 
B-PLANT \\
\end{tabular} & & & 28 & $\mathrm{PCO}$ & 0 & & \\
\hline \begin{tabular}{|l|}
$15-M a y-97$ \\
\end{tabular} & Unimportant & M0324 & CHANGE ROOM TRAILER Q 284E & DYN & \begin{tabular}{|l|} 
GPF \\
\end{tabular} & & & 28 & $\mathrm{PCO}$ & 0 & & \\
\hline 15:May-97 & Tnimpartant & MO326 & DECON TRAILEK @ 242S & DYN & GPF & & & 28 & PCO & 0 & & \\
\hline 15-May-97 & Unimportant & $\overline{\mathrm{MO} 353}$ & MOBILE OFFCE W, OF 4706 & $\overline{\text { DYN }}$ & $\overline{G P F}$ & & & 112 & PCO & 0 & & \\
\hline 15-May-97 & Unimportant & MO371 & MOBILE CHANGE ROOM (271T) & DYN & GPF & & & 47 & $\mathrm{PCO}$ & 0 & & \\
\hline 15-May-97| & Unimportant & M0378 & MOBILE OFFCE (TRL 100) W. OF 4706 & DYN & GPF & & & 172 & $\mathrm{PCO}$ & $\mathbf{0}$ & & \\
\hline 15-May-97 & Unimportant & MO379 & MOBIIE OFACE (TRL, 102) W. OF 4706 & DYN & GPF & & & 172 & PCO & 0 & & \\
\hline 15-May-97 & Unimportant & MO384 & MOBILE OFFICE (2703E) & DYN & GPF & & & 172 & $\mathrm{PCO}$ & 0 & & \\
\hline 15-May-97 & Unimportant & MO387 & CONTROL ROOM TRAILER @ 2703E & DYN & GPF & & & 172 & $\mathrm{PCO}$ & 0 & & \\
\hline 15-May-97| & Unimportant & MO392 & MOBILE OFFICE @ 243G (GROUT) & DYN & GPF & & & 172 & PCO & 0 & & \\
\hline 15-May:-97 & Unimportant & MO394 & MOBILE OFFCE (FMTT TRL 3) & DYN & GPF & 1982 & & 112 & PCO & 0 & & \\
\hline 15-May-97 & Unimportant & MO395 & MOBILE OFFICE (FMIT TRL 5 ) & DYN & GPF & 1982 & & 156 & $\mathrm{PCO}$ & 0 & & \\
\hline 15-May.97 & Tnh. Rugged & MO412 & MASK CLEANING STATION @ 2724W & DYN & GPF & 1984 & 2012 & 515 & PCI & 3 & GOOD & POOR \\
\hline 15-May-97 & Inh. Rugged & MO443 & MOBILE OFFCE 310 & RFSH & LEF & 1993 & 2007 & 51 & $\overline{\mathrm{PC1}}$ & 3 & UIKE NEW & POOR \\
\hline 15-May-97 & Unimportant & MO444 & TRAILERMOBILE OFFICE WRAP & RFSH & WRAP & & & 33 & PCO & $\overline{0}$ & & \\
\hline 15.May.97 & Unimportant & MO446 & TRAILER MOBILE OFFCE WRAP & RFSH & WRAP & & & 62 & $\mathrm{PCO}$ & 0 & & \\
\hline 15-May-97 & Unimportant & MO454 & TRAILERMOBILE OFFICE & RFSH & WRAP & & & 62 & $\mathrm{PCO}$ & 0 & & \\
\hline 15-May-97| & Unimportant & MO465 & MOBULE OFHCE 23RD/DAYTON NEAR RAPSITE & RFSH & WRAP & & & & $\overline{\mathrm{PCO}}$ & $\overline{0}$ & & \\
\hline
\end{tabular}




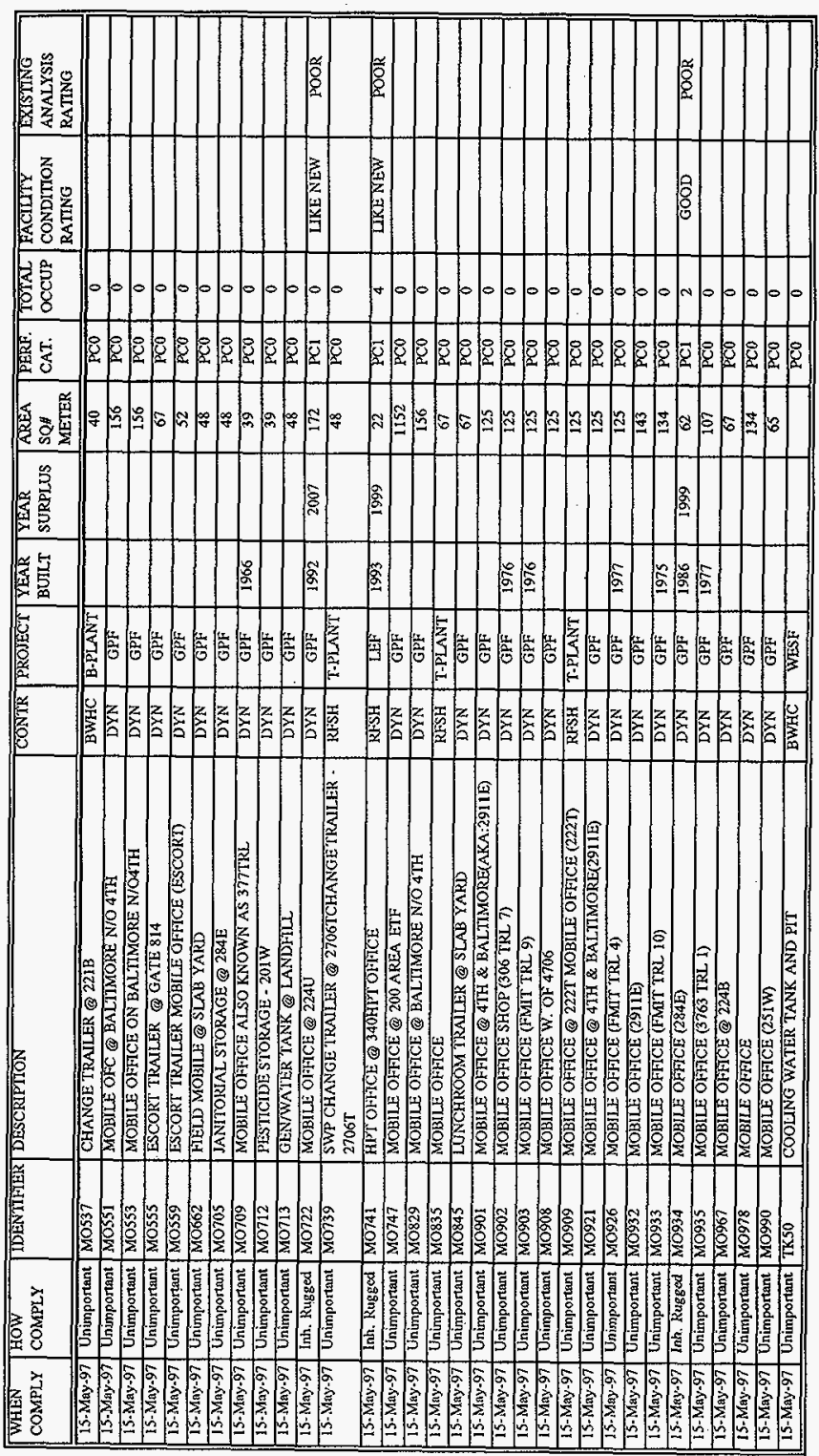


HNF-SP-1175

This page intentionaliy left blank. 
HNF-SP-1175

\section{APPENDIX B}

COMPLIANCE BASELINE FOR EXISTING BUILDINGS AND STRUCTURES

WHERE AN EXEMPTION OR DEVIATION IS BEING REQUESTED 


\section{HNF-SP-1175}

This page intentionally left blank. 
Appendix B. Compliance Baseline For Existing Buildings and Structures Where An Exemption or Deviation is Being Requested.

Tota 1 Assets $=310$

\begin{tabular}{|c|c|c|c|c|c|c|c|c|c|c|c|c|}
\hline $\begin{array}{l}\text { WHEN } \\
\text { COMPLY }\end{array}$ & $\begin{array}{l}\text { Exempt } \\
\text { Status }\end{array}$ & IDENTTHER & $\overline{\text { DESCRIPTION }}$ & CONTRA & Project & $\begin{array}{l}\text { YEAR } \\
\text { BUILT }\end{array}$ & $\begin{array}{l}\text { YEAR } \\
\text { SURPLUS }\end{array}$ & $\begin{array}{l}\text { AREA } \\
\text { SQA } \\
\text { METERS } \\
\end{array}$ & $\begin{array}{l}\text { Perf. } \\
\text { Cat. }\end{array}$ & $\begin{array}{l}\text { TOTAL } \\
\text { OCCUP }\end{array}$ & $\begin{array}{l}\text { FACILITY } \\
\text { CONDITION } \\
\text { RATING } \\
\end{array}$ & \begin{tabular}{|l|} 
EXISTING \\
ANALYSIS \\
RATING \\
\end{tabular} \\
\hline 15- May-97 & $\mathrm{E} 1$ & 1169 & CHEMICAL STORAGE FACILITY & DYN & GPF & 1953 & & 214 & $\mathrm{PCI}$ & 0 & POOR & POOR \\
\hline 15-May-97 & E1 & 1706KER & WATER STUDIES RECIRCULATION BUILDING & DESH & SNF & 1955 & & 232 & $\overline{\mathrm{PCl}}$ & 0 & MARGINAL & POOR \\
\hline 15-May-97 & EI & $181 \mathrm{~B}$ & RIVER PUMP HOUSE - RAW WATER & DYN & GPF & 1960 & & 795 & $\mathrm{PCl}$ & 0 & POOR & POOR \\
\hline 15-May-97 & $\overline{\mathrm{EI}}$ & 181D & RIVER PUMP HOUSE & DYN & GPF & 1960 & & 795 & $\mathrm{PCl}$ & 0 & POOR & POOR \\
\hline 15-May-97 & EI & $1901 Y$ & VALVE HOUSE & DYN & $\overline{\mathrm{GPF}}$ & 1960 & & 55 & FCl & 0 & MARGINAL & POOK \\
\hline 15-May-97 & $\overline{\text { EI }}$ & 19012 & VALVE HOUSE & DYN & GPF & 1960 & & 55 & $\mathrm{PCl}$ & 0 & MARGINAL & POOR \\
\hline 15-May-97 & E1 & $202 \mathrm{~A}$. & PUREX CANYON AND SERVICE FACILTYY & BWHC & PUREX & 1956 & & 12080 & $\mathrm{FCl}$ & 0 & POOR & POOR \\
\hline 15-May-97 & EI & $207 \mathrm{~A}$ & SOUTH RETENTION BASIN & RFSH & $242 \mathrm{~A}$ & 1977 & & & PCl & 0 & MARGINAL & VERIFIED \\
\hline 15-May-97 & E1 & $207 \mathrm{~B}$ & RETENTION BASIN & BWHC & B-PLANT & 1966 & & 5806 & PCI & 0 & POOK & POOK \\
\hline 15-May-97 & E1 & $207 B A$ & MONLTORING BUILDING & BWHC & B-PLANT & 1986 & & 6 & $\mathrm{PCl}$ & $\overline{0}$ & MARGINAL & POOR \\
\hline 15-May-97 & E1 & $207 \mathrm{SL}$ & WATER REILNTION BASIN & RFSH & $222-\$$ & 1952 & 2027 & 200 & PCI & 0 & POOR & POOR \\
\hline 15-May-97 & E1 & 2121 & HISSION PRODUCIS LOAD OUT STATION & BWHC & B-PLANT & 1968 & & 408 & $\overline{\mathrm{PC}} 1$ & 0 & POOR & ACCEPTABLE \\
\hline 15-May-97 & E1 & 2161364 & RETENTTON BASIN & B̈WHC & B-XLANI & 1974 & & & PCI & 0 & MARGINAL & POOR \\
\hline 15-May-97 & E1 & $218 \mathrm{E} 18$ & INACTIVEPUREX TUNNELI & BWHC & PUREX & 1956 & & 800 & PC1 & 0 & POOR & POOR \\
\hline 15-May-97 & $\overline{\mathrm{E} 1}$ & $218 \mathrm{E} 19$ & PUREX TUNNEL 2 & BWHC & PUREX & 1964 & & 3200 & PCI & $\mathbf{0}$ & MARGINAL & POOR \\
\hline 15-May-97 & EI & $221 \mathrm{BA}$ & IS INCH COOLING WATER MONITOR BIDG. & BWHC & B-PLANT & 1966 & & 6 & PC1 & 0 & ProOR & POOR \\
\hline $15 \cdot$ May-97 & E1 & $221 \mathrm{BB}$ & PROCESS STEAM AND CONDENSATE HUILDING & BWHC & B.PLANT & 1968 & & 28 & PC1 & 0 & POOR & POOR \\
\hline 15-May-97 & EI & $221 \mathrm{BC}$ & SWP CHANGE HOUSE & BWHC & B-PLANT & 1973 & & 8 & PC1 & 0 & MARGINAL & POOR \\
\hline $15 \cdot$ May-97 & E1 & $221 B D$ & LAUNDKY STORAGE BUILDING & BWHC & B-PLANT & 1973 & & 40 & PC1 & 0 & MARGINAL & POOR \\
\hline $15-$ May-97 & E! & $222 \mathrm{SB}$ & FLTER BUILDING, HNAC FILTER HOUSE & RFSH & $222-5$ & 1975 & 2027 & 72 & PC1 & 0 & MARGINAL & POOR \\
\hline 15-May-97 & E1 & $222 \mathrm{SC}$ & FILTER BUILDING, NORTH & RFSH & $222-5$ & 1980 & 2027 & 85 & PCI & 0 & MAKGINAL & POOR \\
\hline 15-May-97 & E1 & $222 \mathrm{SD}$ & SOLD WASTE HANDLING AND STORAGE FACILTY & RFSH & $222-S$ & 1983 & 2027 & 50 & $\overline{\mathrm{PCl}}$ & 0 & MARGINAL & POOR \\
\hline 15-May-97 & EI & $222 \mathrm{SF}$ & EQUIPMENT STORAGE, SERVICE BUILDING & RFSH & $222-S$ & 1982 & 2027 & 70 & PC1 & 0 & MARGINAL & POOR \\
\hline 15-May-97 & El & $225 \mathrm{BA}$ & K1 FILTER PIT & BWHC & WESF & 1973 & & 59 & $\overline{\mathrm{PC} 1}$ & 0 & MARGINAL & ACCEPTABLE \\
\hline 15-May-97 & E1 & $225 B C$ & COMPRESSOR FACIITY & BWHC & WESE & 1973 & & 94 & PC1 & 0 & MARGINAL & POOR \\
\hline 15-May-97 & E1 & $225 \mathrm{BD}$ & ENCAPSULATION WASTE MONITORING AND SAMPLE BUILDING & BWHC & WESF & 1973 & & 22 & $\overline{\mathrm{PC}} 1$ & 0 & MARGINAL & POOR \\
\hline 15-May-97 & El & 2312 & MATERIALS ENGINEERING LABORATORY & BWHC & PFP & 1940 & & 4870 & $\mathrm{PC} 1$ & 0 & POOR & POOR \\
\hline 15-May-97 & EI & $242 \mathrm{A702}$ & TURBINE BUILDING & RFSH & $242 \AA$ & 1977 & & 980 & $\mathrm{PC1}$ & 0 & MARGINAL & POOR \\
\hline 15-May-97 & E1 & $2706 \mathrm{~T}$ & EQUIPMENT DECONTAMINATION BUILDING & RFSH & T-PLANT & 1959 & & 370 & PC1 & 0 & POOR & ACCEPTABIE \\
\hline 15-May-97 & E1 & $2715 \mathrm{~B}$ & $\begin{array}{l}\text { PAINT STORAGE BUILDING } \\
\end{array}$ & BWHC & B-PLANT & 1965 & & 30 & $\overline{\mathrm{PCl}}$ & 0 & POOR & POOR \\
\hline 15-May-97 & EI & 2715ED & PAINT STORAGE FACILITY & DYN & GPF & 1980 & & 54 & PC1 & 0 & MARGINAL & POOR \\
\hline 15-May-97 & E1 & $\overline{272 B A}$ & DRY MATERIAL STORAGE BUILDING & BWHC & B.PLANT & 1971 & & 89 & $\overline{\mathrm{PC} 1}$ & 0 & POOR & POOR \\
\hline 15-May-97 & EI & $272 B B$ & INSULATTON STORAGE BUILDING & BWHC & B.PLANT & 1971 & & 79 & PC1 & 0 & POOR & POOR \\
\hline 15-May-97 & El & $2734 \mathrm{ZA}$ & GAS STORAGE & BWHC & PFP & $?$ & & 10 & $\overline{\mathrm{PC} 1}$ & 0 & POOR & $\overline{\mathrm{POOR}}$ \\
\hline 15-May-97 & El & $27342 \mathrm{~B}$ & GAS STORAGE & BWHC & PFP & $?$ & & 10 & PC1 & 0 & POOR & $\overline{\mathrm{POOR}}$ \\
\hline 15-May-97 & El & $\overline{2734 Z C}$ & GAS STORAGE BUILOING & BWHC & $\overline{\mathrm{PFP}}$ & $?$ & & 10 & PCI & 0 & POOR & POOR \\
\hline
\end{tabular}




\begin{tabular}{|c|c|c|c|c|c|c|c|c|c|c|c|c|}
\hline $\begin{array}{l}\text { WHEN } \\
\text { COMPLY }\end{array}$ & $\begin{array}{l}\text { Exempt } \\
\text { Status }\end{array}$ & IDENTTHER & DESCRIPIION & CONTRA & $\overline{\text { Project }}$ & $\begin{array}{l}\text { YREAR } \\
\text { BUILT }\end{array}$ & $\begin{array}{l}\text { YEARR } \\
\text { SURPLUS }\end{array}$ & 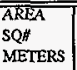 & $\begin{array}{l}\text { Perf. } \\
\text { Cat. }\end{array}$ & $\begin{array}{l}\text { TOTAL } \\
\text { OCCUP }\end{array}$ & $\begin{array}{l}\text { FACIDTY } \\
\text { CONDITION } \\
\text { RATING }\end{array}$ & \begin{tabular}{|l} 
EXISTING \\
ANALYSIS \\
RATING
\end{tabular} \\
\hline |15-May-97| & $\overline{\bar{E} 1}$ & $27342 \mathrm{ZD}$ & PROCESS GAS STORAGE & BWHC & PFP & $?$ & & 10 & $\mathrm{PCI}$ & 0 & POOR & POOR \\
\hline I5-May-97 & El & $2734 Z \mathrm{~F}$ & GAS STORAGE & BWHC & PFP & $?$ & & 10 & PE1 & 0 & POOR & POOR \\
\hline 15-May-97 & EI & $2734 \mathrm{ZG}$ & GAS STORAGE & BWHC & $\overline{P F P}$ & $?$ & & 10 & $\mathrm{PCl}$ & 0 & POOR & POOR \\
\hline IS-Mny-97 & $\mathrm{Et}$ & $27342 \mathrm{H}$ & GAS STORAGE & BWHC & $\overline{P F P}$ & $?$ & 2007 & 10 & $\mathrm{FC1}$ & 0 & $\mathrm{POOK}$ & POOR \\
\hline 15-Mny-97 & Ei & $2734 Z 3$ & UQUDD NITROGEN STOKAGE TANK/BUILDING & BWHC & PFP & $?$ & & 10 & $\mathrm{PC} 1$ & 0 & POOR & POOR \\
\hline 15-May-97 & EI & $27342 \mathrm{~K}$ & GAS SIORAGE & BWHC & PFP & $?$ & & 10 & $\mathrm{PCl}$ & 0 & POOR & POOR \\
\hline 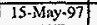 & $\overline{E l}$ & $277 \mathrm{~T}$ & BLOW DOWN BUILDING & RFSH & T-PLANT & 1977 & & 120 & FCI & $\overline{0}$ & MARGINAL & ACCEPTABLE \\
\hline 15-May-97| & El & $282 B$ & WATER PUMP HOUSE & BWHC & WESF & 1963 & & 21 & $\overline{\mathrm{PCl}}$ & 0 & POOR & POOR \\
\hline 15-May -97 & EI & $282 B A$ & WATER PUMP HOUSE & BWHC & WESF & 1968 & & 21 & FCI & 0 & POOR & POOR \\
\hline 15-May-97| & $\mathrm{ET}$ & $2901 Y$ & 100200 VALVE HOUSE & DYN & GPF & 1960 & & 55 & FCI & 0 & MAKGINAL & POOR \\
\hline 15-May-97 & EI & $291 \mathrm{~A}$ & AR FLTER/STACK PLERUM & BWHC & PUREX & 1956 & & 250 & $\mathrm{FCI}$ & 0 & POOR & $\mathrm{POOR}$ \\
\hline 15-May-97| & EI & $291 \mathrm{AE}$ & FLTER CELL 84 & BWHC & PUREX & 1956 & & 420 & $\mathrm{FCl}$ & 0 & POOR & POOR \\
\hline 15-May-97 & EI & $291 B A$ & EXHAUST ATR SAMPLE HOUSE & BWHC & B-PLANT & $\overline{1955}$ & & 5 & $\overline{\text { PCI }}$ & 0 & POOR & POOR \\
\hline 15-Mhy.97 & EI & 291813 & EXHAUST AIR HLTERS, INSTRUMENTATION HOUSE & BWHC & B-PLANT & 1965 & & 13 & $\mathrm{PCl}$ & 0 & FOOR & POOR \\
\hline 15-May-97 & El & $291 \mathrm{~T}$ & EXHAUST STACK & RFSH & T-PLANT & 1947 & & 100 & $\overline{\mathrm{PCl}}$ & $\mathbf{0}$ & POOR & ACCEPTABLE \\
\hline 15-May-97 & ET & $292 \mathrm{~B}$ & STACK MONTTORING STATION & BWHC & B-PIANT & 1944 & & 31 & $\mathrm{PCI}$ & 0 & POOR & POOR \\
\hline 15-May-97 & EI & 292T & FSSION IRODUCTS RELEEASE LABORATOKY & RFSH & T.PLANT & 1950 & & 85 & $\mathrm{FCl}$ & 0 & POOR & ACCEPTAB̈LE \\
\hline 15-May-97 & $\mathrm{EI}$ & $303 \mathrm{~A}$ & SIORAGE BUILDING & BWHC & FFF & $\overline{1943}$ & & 120 & $\overline{P C l}$ & 0 & POOR & POOR \\
\hline 15-May-97 & EI & $303 \mathrm{~B}$ & STORAGE BUILDING & BWHC & FFF & 1943 & & 120 & PCI & 0 & POOR & POOR \\
\hline 15-May-97 & E1 & $303 \mathbf{E}$ & ESTSENTAL MATERIALS STORAGEBUILDING & BWHC & FFF & 1943 & & 120 & PC1 & 0 & POOR & $\mathrm{POOR}$ \\
\hline 15-May-97 & EI & $303 \mathrm{~F}$ & PUMP HOUSE & BWHC & TiFF & 1943 & & 120 & $\mathrm{PCI}$ & 0 & POOR & POOR \\
\hline 15-May-97 & EI & $303 \mathrm{G}$ & ESSENIIAL MATERIALS SIORAGE BULLDING & BWHC & FFF & 1943 & & 120 & PCI & 0 & POOR & POOR \\
\hline 15-May-97 & E1 & $303 \mathrm{~K}$ & $\begin{array}{l}\text { CONTAMINATED WASTE STORA GE FACILTTY, DECONTAM \& } \\
\text { BATTERY CHARGINGFACIUTY }\end{array}$ & BẄHC & FFF & $\overline{1943}$ & & 120 & $\mathrm{PCl}$ & 0 & POOR & POOR \\
\hline 15-Mry-97 & E1 & $303 \mathrm{M}$ & URANIUM OXIDE FACIIITY & BWHC & FFF & 1983 & & 264 & $\overline{\mathrm{PCI}}$ & $\mathbf{0}$ & MARGINAL & POOR \\
\hline 15-May-97 & E1 & 304 & URANUWM CONCRETION FACILTYY AND STORAGE AREA & BWHC & FFF & 1954 & & 715 & PC1 & $\overline{0}$ & POOR & POOK \\
\hline 15-May-97 & E1 & 308 & FUELS DEVELOPMENT LABORATORY & BWHC & FFF & 1960 & & 5667 & PC1 & 0 & POOR & VERIFABLE \\
\hline 15-May-97 & E1 & $\overline{308 \mathrm{~A}}$ & FUELS DEVELOPMENT LABORATOR & BWHC & FFF & 1975 & & 873 & $\overline{\mathrm{PC1}}$ & $\overline{0}$ & POOR & POOR \\
\hline 15-May-97| & E1 & 3135 & $313-5$ & BWHC & FFF & 1943 & & 2764 & $\overline{\mathrm{PCI}}$ & 0 & POOR & POOR \\
\hline 15-May-97| & E1 & $324 \mathrm{~B}$ & CHEMICAL ENGINEERRTING LABORATORY, EXHAUST STACK & BWHC & FFF & 1965 & & 5 & $\mathrm{PC1}$ & 0 & MARGINAL & MARGINAL \\
\hline 15-May-97 & EI & $340 \mathrm{~A}$ & WASTE RETENTION BUILDING 340 ANNEXX & RFSH & $\overline{Z E F}$ & 1953 & 1999 & 127 & PC1 & $\overline{0}$ & POOR & POOR \\
\hline 15-May-97| & ET & $340 \mathrm{~B}$ & WASTE LOADOUT BUILDING & RFSH & LEF & 1953 & 1999 & 112 & PCI & 0 & POOR & POOR \\
\hline \begin{tabular}{|l|}
$15-$ Mny-97 \\
\end{tabular} & E1 & 3706 & INFORMATION SERVICES & DYN & GPF & 1944 & & 3485 & $\overline{\mathrm{PC1}}$ & 0 & POOR & \\
\hline $25-$ Kay -97 & $\mathrm{ET}$ & $3707 \%$ & RADIATTON MONTTORING BUILDING & RFFH & LEF & 1964 & 2017 & 13 & PC1 & 0 & POOR & POOR \\
\hline \begin{tabular}{|l|}
$15-$ May-97 \\
\end{tabular} & E1 & $3707 \mathrm{G}$ & CHANGE HOUSE & BWHC & FFF & 1940 & & 18 & PC1 & 0 & POOR & POOR \\
\hline 15-May-97| & E1 & 3711 & MAINTENANCE STORAGE BUILDING & DYN & GPF & 1974 & 2007 & 298 & $\overline{\mathrm{PCI}}$ & 0 & POOR & POOR \\
\hline 15-May-97 & E1 & 3712 & STORAGE BUILDING & BWHC & FFF & 1961 & & 891 & $\overline{\mathrm{PC1}}$ & 0 & POOR & $\mathrm{POOR}$ \\
\hline $\begin{array}{l}\text { 15-Kay-97 } \\
\end{array}$ & ET & 3716 & STOKAGE BUILDING & BWWC & $F F$ & 1938 & & 298 & POI & 0 & POOR & POOR \\
\hline \begin{tabular}{|l|}
$15-$ May-97 \\
\end{tabular} & E1 & $3718 \mathrm{G}$ & STORAGE BUILDING & BWHC & FFF & 1978 & & 1219 & PC1 & 0 & MARGINAL & ACCEPTABLE \\
\hline 15-May-97 & E1 & 3723 & SOLVENT AND ACID STORAGE BUILDING & BWEAC & FFF & 1972 & & 13 & PC1 & 0 & POOR & POOR \\
\hline 15-May-97] & E1 & & LABORATORY & DYN & GPF & 1980 . & & 336 & PC1 & & POOR & POOR \\
\hline
\end{tabular}




\begin{tabular}{|c|c|c|c|c|c|c|c|c|c|c|c|c|}
\hline $\begin{array}{l}\text { WHEN } \\
\text { COMPLY }\end{array}$ & $\begin{array}{l}\text { Exempt } \\
\text { Stan1s }\end{array}$ & IDENTIFER & DESCRIPTION & CONTKA & Project & $\begin{array}{l}\text { YEAR } \\
\text { BUILT }\end{array}$ & $\begin{array}{l}\text { YEAR } \\
\text { SURPLUS }\end{array}$ & \begin{tabular}{|l|} 
AREA \\
SQH \\
METERS \\
\end{tabular} & $\begin{array}{l}\text { Perf. } \\
\text { Cat. }\end{array}$ & TOTAL & $\begin{array}{l}\text { FACIIITY } \\
\text { CONDITION } \\
\text { RATING }\end{array}$ & $\begin{array}{l}\text { EXISTING } \\
\text { ANALYSIS } \\
\text { RATING }\end{array}$ \\
\hline 15-May-97| & E1 & $4713 \mathrm{D}$ & INTERIM MAINTENANCE AND STORAGE FACIUTY & BWHC & FFF & 1978 & & 587 & $\overline{\text { PC1 }}$ & $\overline{0}$ & MARGINAL & $\overline{\mathrm{POOR}}$ \\
\hline 15-May-97 & EI & 4721 & FFTF EMERGENCY GENERATOR BUILDING & BWHC & FFFF & 1978 & & 186 & PCI & 0 & MARONAL & VERUFABLLE \\
\hline 15-May-97 & E1 & 4727 & MAINTENANCE FLAMMABLE STORAGE & BWHC & FFTF & 1978 & & 13 & $\mathrm{PCl}$ & 0 & MARGINAL & POOR \\
\hline 15-May-97 & E1 & 484 & ICCW EQUUPMENT BUILDING & BWHC & FFTF & 1978 & & 784 & $\mathrm{PCl}$ & 0 & MARGINAL & POOR \\
\hline 15-May-97 & E1 & $4842 \mathrm{~A}$ & SWTTCHGEAR 45IB SUBSTATYON & BWHC & FFTF & 1978 & & 206 & PCI & 0 & MARGINAL & POOR \\
\hline 15-May-97 & E1 & $621 \mathrm{~B}$ & WYE BARKICADE, EMERGENCY GENERATOR SHELTER & DYN & GPF & 1944 & & 3 & $\mathrm{PC1}$ & 0 & POOR & FOOR \\
\hline 15:-May-97| & E1 & M0312 & LAUNDRY STORAGE Q 225B & $\mathrm{BWHC}$ & WESF & 1974 & & 24 & $\mathrm{PCI}$ & $\overline{0}$ & MARGINAL & POOR \\
\hline 15-May-97 & E1 & M0674 & MOBILE OFFCE 243 (GROUT) & DYN & GPF & 1972 & 2002 & 48 & $\mathrm{PCl}$ & 0 & POOR & POOR \\
\hline 15-May-97 & E1 & MO946 & MOBILE OFFCE - PUREX & DYN & GPF & 1976 & & 112 & $\mathrm{PCl}$ & 0 & MARGINAL & POOR \\
\hline 15-May-97 & E1 & MO555 & MOBILE OFHCE & DYN & GPF & 1975 & & 112 & FCI & 0 & MARGINAL & POOK \\
\hline 15-May-97 & E1 & TK100 & LOW LEVEL WASTE TANK AND PIT & BWHC & WESF & 1973 & & & PCI & 0 & MARGINAL & POOR \\
\hline 15-May-97| & E3 & $1167 \mathrm{~A}$ & OFFCEEXCESS SALVAGE & DYN & GPF & 1953 & 2002 & 180 & $\mathrm{PCI}$ & 17 & POOR & POOR \\
\hline 15-May-97 & B3 & $1823 \mathrm{TD}$ & PRACTCAL TRAINING - FENCED AREA & DYN & GPF & 1990 & & 172 & $\mathrm{PCl}$ & $40^{\circ}$ & GOOD & POOR \\
\hline 15-May-97 & E3 & $21629 \mathrm{~A}$ & CONTAMINATED SOIL REMOVAL FACIUTY & BWHC & PFP & 1970 & & 100 & PCI & 9 & POOR & POOR \\
\hline $15-$ May-97 & E3 & $216 \mathrm{Z9B}$ & INDUSTRIAL BUILDING & BWHC & PFP & 1970 & & 20 & $\mathrm{PCI}$ & 9 & POOR & POOR \\
\hline 15-May-97 & E3 & $219 \mathrm{~S}$ & RAD WASTE STAGING \& TRANSFER & RFSH & $222-5$ & 1951 & 2027 & 100 & PCL & 6 & POOR & POOR \\
\hline 15-May -97 & $\mathrm{E} 3$ & $2342 B$ & WASTE MATERIAL STORAGE/SHOP BUILDING & BWHC & PFP & 1940 & 2007 & 100 & $\mathrm{PCl}$ & 20 & POOR & POOR \\
\hline 15-May-97 & $\mathrm{B} 3$ & $241 \mathrm{~L}$ & $\begin{array}{l}\text { TANK FARM WASTE DISPOSAL BUILDING, TREATMENT TANK } \\
\text { (D-5)Z-TANK FARM }\end{array}$ & BWHC & PFP & 1949 & 2007 & 170 & PC1 & 9 & POOR & POOR \\
\hline 15-May-97 & E3 & $241 \mathrm{ZA}$. & SAMPLE/LOADOUT BUILDING & BWHC & PFP & 1960 & 2007 & 30 & PC1 & 9 & POOR & POOR \\
\hline $15-$ May-97 & E3 & $243 \mathrm{Z}$ & LOW LEVEL WASTE TREATMENT FACILTY & BWHC & PFP & 1992 & 2007 & 150 & FC1 & 19 & LIKE NEW & POOR \\
\hline $15-$ May-97 & E3 & 2701ZA & CENTRAL ALARM STATION FACILTYY, PATROL AMS/Z-PLANT & BWHC & PFP & 1976 & 2007 & 100 & PC1 & 15 & MARGINAL & POOR \\
\hline 15-May-97 & E3 & 270120 & PLUTONIUM FINISHING PIANT BADGEHOUSE & BWHC & PFP & 1991 & 2007 & 150 & PC1 & 20 & GOOD & POOR \\
\hline 15-May-97 & E3 & 27022 & COMMUNICATTONS SUPPORT BUILDING, MICROWAVE BUILDING & BWHC & PEP & 1981 & 2007 & 20 & $\mathrm{PC1}$ & 9 & MARGINAL & POOR \\
\hline 15-May-97 & E3 & $2704 \mathrm{Z}$ & OFFCE ADMINISTRATTON BUILDING & BWHC & PFP. & 1940 & 2007 & 100 & PC1 & 30 & POOR & POOR \\
\hline 15-May-97 & $\mathrm{E3}$ & $2705 \mathrm{Z}$ & PFP OPERATTONS CONTROL FACIDTYI BUILDONG & BWHC & PFP & 1991 & 2007 & 75 & PC1 & 20 & GळD & POOR \\
\hline 15.May-97 & E3 & $2707 \mathrm{~W}$ & CHANGE HOUSE & DYN & GPF & 1944 & 1999 & 243 & $\mathrm{PC1}$ & 4 & POOR & POOR \\
\hline 15-May-97 & $E_{3}$ & $2710 \mathrm{E}$ & COAL HANDLER'S SHELTER & DYN & GPF & 1960 & & 23 & $\mathrm{PC1}$ & 3 & MARGINAL & POOR \\
\hline 15-May-97 & $\mathrm{E}_{3}$ & 27122 & STACK MONITORING STATION & BWHC & PFP & 1955 & 2047 & 10 & PC1 & 9 & POOR & POOR \\
\hline 15-May-97] & E3 & $2715 E C$ & PAINTSHOP & DYN & $\mathrm{GPF}$ & 1982 & 2007 & 92 & PCI & 3 & MARGINAL & POOR \\
\hline 15-May-97 & $\mathrm{E3}$ & $2715 \mathrm{~T}$ & PAINT STORAGE BUILDINGPAINT STORAGE BUILDING & RFSH & T-PLANT & 1982 & & 60 & $\mathrm{PCl}$ & 3 & MARGINAL & ACCEPTABBLE \\
\hline 15-May-97 & E3 & 27152 & OIL AND SOLVENT STORAGE BUILDING & BWHC & PFP & 1970 & 2007 & 30 & $\overline{\mathrm{PCl}}$ & 9 & MARGINAL & POOR \\
\hline 15-May-97 & E3 & 2715ZL & OIL STORAGE BUILDING & BWHC & PFP & 1970 & 2007 & 30 & $\mathrm{PCl}$ & 9 & MARGINAL & POOR \\
\hline 15-May-97 & $\mathrm{E3}$ & $2716 \mathrm{~S}$ & DABORATOKY STORAGE & RFSH & $222-5$ & 1983 & 2027 & 170 & PC1 & 5 & MARGINAL & POOR \\
\hline 15.May -97 & E3 & 2719EA & MEDICAL AID STATION & DYN & GPF & 1981 & 2012 & 139 & PC1 & 8 & MARGINAL & POOR \\
\hline 15-May-97| & $E^{3}$ & $2721 \mathrm{EA}$ & FRE SYSTEMS MAINTENANCE BUIIDDING & DYN & GPF & 1984 & 2007 & 219 & $\mathrm{PC1}$ & 55 & MARGINAL & POOR \\
\hline 15-May-97 & $E 3$ & 27212 & EMERGENCY GENERATOR BUILDING, EMERGENCY TURBINE & BWHC & PFP & 1981 & 2047 & 80 & PCI & 2 & MARGINAL & POOR \\
\hline 15-May-97| & $E 3$ & 27252 & STORAGE BUILDING & BWTEC & PFP & 1970 & 2007 & 30 & PCI & 9 & MARGINAL & POOR \\
\hline 15-May-97 & E3 & $2727 \mathrm{Z}$ & SUPPLY STORAGE BUILDING & BWAC & PFP & $?$ & 2007 & 50 & PC1 & 9 & POOR & POOR \\
\hline 15:May-97 & $\mathrm{E}_{3}$ & $2728 \mathrm{~W}$ & DIMENSIONALIINSPECTION BUILDING & DYN & GPF & 1979 & 2017 & 183 & PC1 & 9 & MARGINAL & POOR \\
\hline 15-May-97| & E3 & $2729 \mathrm{Z}$ & STORAGE BUILDING & BWHC & PFP & & 2007 & 100 & PC1 & 9 & POOR & POOR \\
\hline
\end{tabular}


HNF-SP-1175

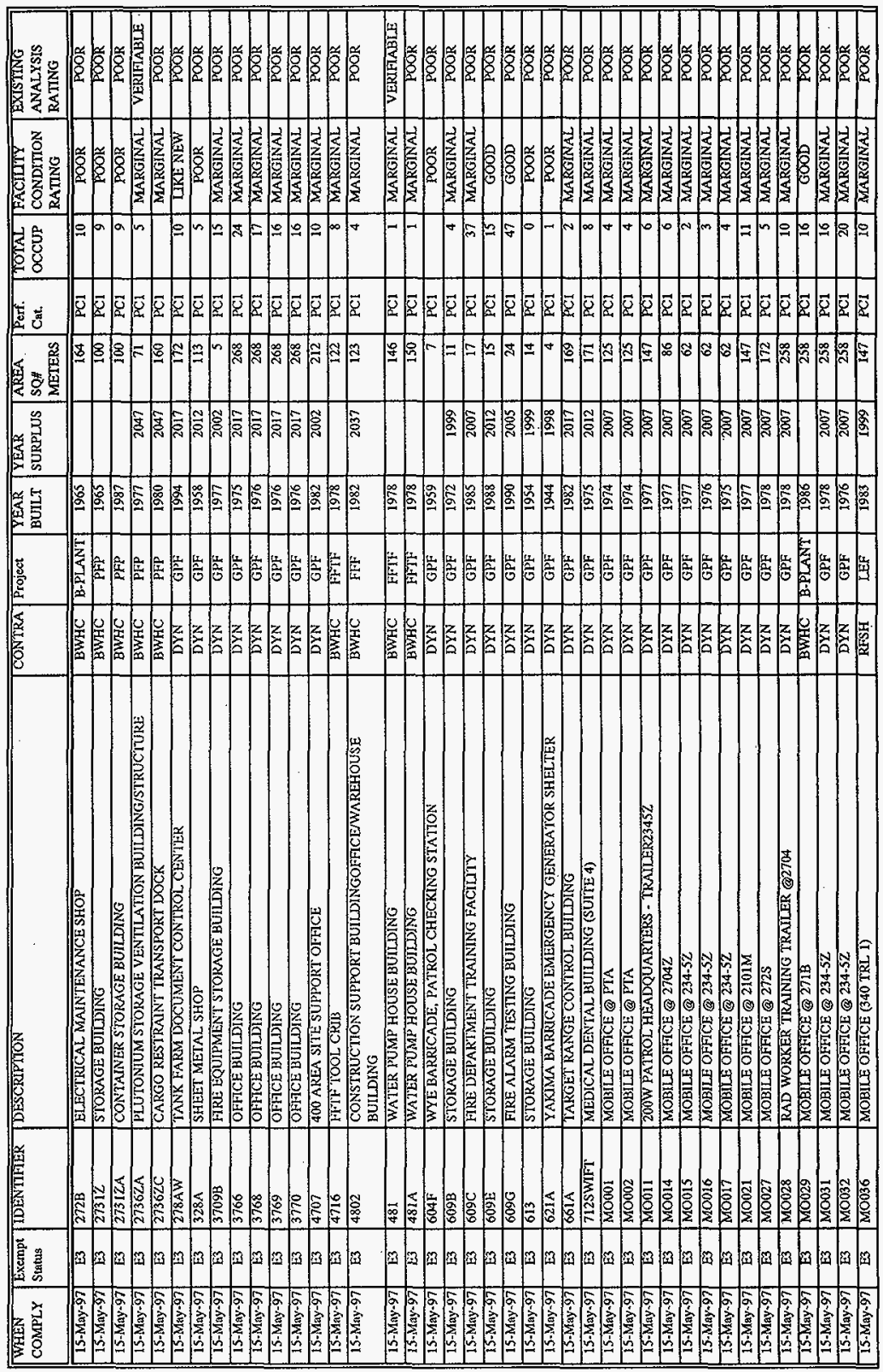




\begin{tabular}{|c|c|c|c|c|c|c|c|c|c|c|c|c|}
\hline $\begin{array}{l}\text { WHEN } \\
\text { COMPLY }\end{array}$ & $\begin{array}{l}\text { Exempt } \\
\text { Status }\end{array}$ & IDENTIFIER & DESCRIPTON & CONARA & Project & $\begin{array}{l}\text { YEAR } \\
\text { BUILT }\end{array}$ & $\begin{array}{l}\text { YEEAR } \\
\text { SURPLUS }\end{array}$ & \begin{tabular}{|l|} 
AREA \\
SQH \\
METERS
\end{tabular} & Perf. & $\begin{array}{l}\text { TOTAL } \\
\text { OCCUP }\end{array}$ & $\begin{array}{l}\text { FACITYY } \\
\text { CONDITION } \\
\text { RATING }\end{array}$ & $\begin{array}{l}\text { EXISTING } \\
\text { ANALYSIS } \\
\text { RATING }\end{array}$ \\
\hline 15-May-97! & $\overline{E 3}$ & $\overline{\mathrm{M} 0039}$ & MOBILE OFFICE (- 27045 & $\overline{\text { DYN }}$ & GPF & 1979 & 2007 & 258 & $\overline{\mathrm{PCI}}$ & 16 & MARGINAL & POOR \\
\hline 15-May-97] & B3 & MO040 & MOB1LE OFFCE @ $284 \mathrm{E}$ & DYN & GPF & 1979 & 2007 & 258 & PCI & 16 & MARGINAL & POOK \\
\hline 15-May-97 & E3 & MO041 & MOBILE OFFCE @ $243 \mathrm{G}$ & DȲN & GPF & 1979 & 2007 & 172 & $\mathrm{PCI}$ & 8 & MARGINAL & POOR \\
\hline 15-May-97 & E3 & M0042 & MOBILE OFFICE @ 2750E & DYN & GPF & 1979 & 2007 & 258 & PCI & 10 & MAQRGINAL & POOR \\
\hline 15-May-97 & E3 & M0048 & 200 AREA CENTRAL SIGN SHOP (3) 274E & DYN & GPF & 1979 & 2007 & 172 & PCI & 11 & MARGINAL & POOR \\
\hline 15-May-97 & $\mathrm{B} 3$ & M0052 & MOBILE OFFICE (333 TRL 1) & BWFC & FFF & 1980 & 1999 & 170 & $\mathrm{PCl}$ & 9 & MARGINAL & POOR \\
\hline $\mid 15-$ May-97| & $\overline{E 3}$ & MO101 & MOBILE OFFCE Q 1711K (FKA 1111N) & DESH & SNF & & & 147 & $\mathrm{PCl}$ & 50 & GOOD & POOR \\
\hline 15-May-97 & 13 & MO102 & MOBILE OFFCE TRAILIR JIO9N & DESH & SNF & & & 147 & $\mathrm{PCI}$ & 50 & GOOD & POOR \\
\hline 15-May-97 & E3 & MO108 & MOBILE OFFCE @ 4 TH \& BALTTMORE(573) & DYN & GPF & 1983 & 2007 & 156 & PC1 & 7 & MARGINAL & POOR \\
\hline 15-May-97| & $\mathrm{B} 3$ & MO109 & OFHCBCHANGE/RANING TRAILER Q224B & DYN & GPF & 1977 & 2002 & 172 & PCI & क & MARGINAL & POOK \\
\hline 15-May-97 & E3 & MO201 & MOBILE OFFICE @ $2704 \mathrm{~W}$ & DYN & $\overline{G P F}$ & 1976 & 1998 & 86 & PC1 & & MARGINAL & POOR \\
\hline 15-May-97| & E3 & MO203 & GRAPHICS FACIL'TY \& 284E (ATT TOMO931) & DYN & GPF & 1987 & 2007 & 61 & PC1 & 8 & MARGINAL & POOR \\
\hline 15-May-97] & E3.3 & M0206 & MOBILE OFFICE @ B PLANT 225B & DYN & GPF & 1977 & 2002 & 62 & PEI & 5 & MARGINAL & POOR \\
\hline 15:May-97| & $\mathrm{E3}$ & M0214 & (AKA:1701K)MOBILEOKHICE TKAILER & DESH & SNF & & & 170 & REI & 50 & 0,000 & POOR: \\
\hline 15-May-97 & {$[13$} & $\mathrm{MO222}$ & GUN CLEANING TRALER \& PTA & DYN & $\overline{\text { GPF }}$ & 1977 & 2007 & 67 & PCI & 5 & MARGINAL & POOR \\
\hline 15-May-97| & E3 & M0223 & CHANGE TRAILER NOO 272 WA & RFSH & SWM & 1982 & & 58 & PC1 & I0 & MARGINAL & POOR \\
\hline 15-May-97 & $\mathrm{B3}$ & MO227 & MOBILE OFFICE @ UNSECURED CORE AREA & DYN & GPF & 1982 & 2002 & 172 & PC1 & 13 & MARGINAL & POOR \\
\hline 15-May-97 & $\mathrm{E} 3$ & MO232 & MOBILE OHFCE $\triangle 271 \mathrm{~B}$ & BWHC & B.PLANT & 1986 & & 170 & PC1 & 21 & MARGINAL & POOR \\
\hline 15-May-97 & EB & MO236 & TELECOMMUNICATTONS SHOP Q 1154MOBILE OFFCE (II54) & DESH & SNE & & & 170 & PCI & 50 & GOOD & POOR \\
\hline 15-May-97 & E3 & MO239 & \begin{tabular}{|l|} 
MOBILE OFFCE \\
\end{tabular} & DESH & SNF & & & 170 & $\mathrm{PC1}$ & 50 & GOOD & POOR \\
\hline 15-May-97| & $\mathrm{E}$ & MO247 & MOWILE OFFCE - TRALLER GATE 815 & DYN & GPF & 1990 & 2007 & 172 & $\mathrm{PC1}$ & 10 & GOOD & POOR \\
\hline 15-May-97 & $\mathrm{E} 3$ & Mo250 & MOBILE OFFCE \& 234-SZ (OUTSIDE FENCE) & DYN & GPF & 1990 & 2007 & 172 & PC1 & 23 & GOOD & POOR \\
\hline 15-May-97 & E3 & MO2S: & MOBILE OFFCE, - TRAILER GATE 850 & DYN & $\overline{\mathrm{GPF}}$ & 1990 & 2007 & 172 & $\mathrm{PC1}$ & 12 & GOOD & POOR \\
\hline 15-May-97| & $\overline{E 3}$ & MO254 & MOBLLE OFFICE $@ 622 G$ & DYN & GPF & 1990 & 2007 & 172 & $\mathrm{PCl}$ & $\pi$ & GOOD & POOR \\
\hline 15-May-97 & E3 & MO255 & \begin{tabular}{|l|l|l} 
OBILE OFFCE $B$ 622G \\
\end{tabular} & DYN & GPF & 1990 & 2007 & 172 & $\mathrm{PC1}$ & 14 & GOOD & POOR \\
\hline $15 \cdot$ May -97 & E3 & MO256 & MOBILE OFFCE EOO $2711 \mathrm{E}$ & DYN & GPF & 1990 & 2012 & 172 & PC1 & 11 & GCOD & POOR \\
\hline 15:May-97 & E3 & M0257 & MOBILE OFFCE EO $2711 \mathrm{E}$ & $\overline{\mathrm{DYN}}$ & GPF & 1990 & 2012 & 172 & $P C 1$ & 11 & GOOD & POOOR \\
\hline 15-May-97 & E3 & M0258 & MOBILE OFFCE $\triangle$ FMT & $\overline{D Y N}$ & GPF & 1990 & 2017 & 172 & PC1 & 15 & GOOD & POOR \\
\hline 15-May-97 & E3 & M0259 & MOBILE OFFCE Q FMTT & DYN & GPF & 1990 & 2017 & 172 & FCI & 15 & GOOD & POOR \\
\hline 15-May-97 & $E 3$ & MO262 & MOBILE OFFCE Q FMIT & DYN & GPF & 1990 & 2017 & 172 & PC1 & 15 & G000 & POOR \\
\hline 15-May-97 & E3 & MO263 & MOBILE OFFCE - FMT & $\overline{D Y Y N}$ & GPF & 1990 & 2017 & 172 & $\mathrm{PCl}$ & 15 & GOOD & POOR \\
\hline 15-May-97 & E3 & MO264 & MOBILE OFFICE Q FMMT & DYN & GPF & 1990 & 2017 & 172 & FCI & 15 & GOOD & POOR \\
\hline 15-May-97 & E3 & MO266 & MOBILE OFFCE @ 272AW TANK FARMS & $\overline{D Y N}$ & GPF & 1990 & 2007 & 172 & $\mathrm{PC1}$ & 16 & GOOD & PDOR \\
\hline 15-May-97) & $E_{3}$ & M0267 & MOBILE OFFCE Q 272AW TANK FARMS & $\overline{D Y N}$ & GPF & 1990 & 2007 & 172 & PC1 & 16 & GOOD & POOR \\
\hline 15-May-97 & E3 & MO268 & MOBILE OFFCE @ $272 A W$ TANK FARMS & $\overline{\mathrm{DYN}}$ & GPF & 1990 & 2007 & 172 & $\overline{\mathrm{PCI}}$ & 16 & GOOD & $\mathrm{POOR}$ \\
\hline 15-May-97 & E3 & MO270 & MOBILE OFFCE (3765T1) & BWHC & FFF & 1991 & 2001 & 172 & $\mathrm{PC1}$ & 20 & GOOD & ACCEYTABLE \\
\hline 15:May-97 & E3 & MO271 & MOBILE OFFCE (3765T1) & BWHC & FFF & 1941 & 2001 & 172 & $\mathrm{PC1}$ & 20 & GO0D & ACCEPTABIE \\
\hline 15-May-97| & E & MO275 & MOBILE OFFCE (32412) & BWHC & FFF & 1991 & 2001 & 170 & PC1 & 20 & GOOD & ACCEPTABLE \\
\hline 15-May-97 & $E 3$ & $\mathrm{MO282}$ & MOBILE OFFCE @ GROUT & DYN & GPF & 1993 & 2007 & 172 & $\mathrm{PC1}$ & 18 & IIKE NEW & POOR \\
\hline 15-May-97 & $E 3$ & MO283 & MOBILE OFHCE @ QROUT & DYN & GPF & 1993 & 2007 & 172 & $\mathrm{PCl}$ & 18 & LKKE NEW & POOR \\
\hline 15-May-97 & $E$ & MO284 & MOBILE OFFCE @ GROUTT & DYN & GPF & $19 \overline{93}$ & 2007 & 172 & $\mathrm{PC1}$ & 18 & XIKE NEW & POOR \\
\hline
\end{tabular}




\begin{tabular}{|c|c|c|c|c|c|c|c|c|c|c|c|c|}
\hline $\begin{array}{l}\text { WOMN } \\
\text { COMPLY }\end{array}$ & $\begin{array}{l}\text { Exempit } \\
\text { Status }\end{array}$ & TDENTTIER & DESCRIPTION & CONRAA & Project & $\begin{array}{l}\text { YEAAR } \\
\text { BUILT }\end{array}$ & $\begin{array}{l}\text { YEAR } \\
\text { SURPLUS }\end{array}$ & \begin{tabular}{|l|} 
AREA \\
SQE \\
METERS \\
\end{tabular} & $\begin{array}{l}\text { Perf- } \\
\text { Cat. }\end{array}$ & \begin{tabular}{l|} 
TOTAL \\
OCCUP
\end{tabular} & $\begin{array}{l}\text { FACIOITY } \\
\text { CONDITION } \\
\text { RATANG }\end{array}$ & $\begin{array}{l}\text { EXISTING } \\
\text { ANALYSIS } \\
\text { RATING }\end{array}$ \\
\hline 15-May-97 & $\overline{\mathrm{E} 3}$ & MO302 & ARMORER SHOP (MOBILE OFFCE) @PTA & $\overline{\overline{D Y N}}$ & GPF & 1974 & 2007 & 112 & $\overline{\mathrm{PC} 1}$ & 3 & MARGINAL & POOR \\
\hline 15.May-97| & E3 & MO303 & MOBILE OFFICE W. OF $1167 \mathrm{~A}$ & DYN & GPF & 1975 & 1998 & 112 & PC1 & 4 & MAKGINAL & POOR \\
\hline 15-May-97 & $E_{3}^{3}$ & MO346 & MOBILE OFFICE $\otimes 222 \mathrm{~S}$ & DYN & GPF & 1977 & 2007 & 112 & PCI & II & MARGINAL & POOR \\
\hline 15-May-97 & $\mathrm{E} 3$ & MO347 & MOBILE OFFCE @ 202A (ATT'D TO MO948) & DYN & GPF & 1975 & 2002 & 120 & $\mathrm{PC1}$ & 6 & POOR & POOR \\
\hline |15-May-97| & E3 & MO354 & MOBMLE OFFCE @ $2400 E$ & DYN & $\overline{G P F}$ & 1974 & 2002 & 120 & $\mathrm{PCl}$ & 8 & POOR & POOR \\
\hline 15-May-97| & E3 & MO355 & MOBILE OFFCE Q $202 A$ (ATT T TO MOSA2) & DYN & GPF & 1974 & 2002 & 120 & PC1 & 8 & POOR & POOK \\
\hline |5-May-97) & $\mathrm{E}_{3}$ & MO368 & PATROL TRNINING (MOBILE OFFCE) QPTA & DYN & $\overrightarrow{G P F}$ & 1975 & 2007 & 112 & PC1 & 4 & MAROINAL & POOR \\
\hline 15-May-97 & E3 & MO382 & MOBILE OFFCE TRAILER - 172IK & DESH & SNF & & & 170 & $\mathrm{PCl}$ & so & GOOD & POOR \\
\hline 15-May-97) & $\mathrm{E} 3$ & MO386 & MOLILE OFFCE (6) DMRHF (24006) & $\overline{D Y N}$ & $\overline{\mathrm{GPF}}$ & 1986 & 2007 & 172 & $\overline{\mathrm{PCI}}$ & 9 & MARGINAL & POOR \\
\hline 15-May-97 & $E^{3}$ & MO388 & SRT HEADQUARTERS (2721EA) & $\overline{D Y N}$ & GPF & 1989 & 2002 & 12 & PC1 & 16 & GOON & POOR \\
\hline 15-May-97| & E3 & MO393 & MOBILE OFFICE \& $272 A W$ TANK FARMS & DYN & GPF & 1974 & $200 \overline{2}$ & 112 & PCI & 10 & MARGINAL & POOR \\
\hline 15-May-97 & E & \begin{tabular}{|l|l|}
$M 0401$ \\
\end{tabular} & MOBILE OFHCE 6 1719K (FKA: 1117N) & DESH & SNF & & & 170 & $\mathrm{PCI}$ & 50 & GOOD & pook \\
\hline 15-Msgy-97 & E3 & M0402 & MOBILE OFFCE TRALER $1718 \mathrm{~K}$ & DESH & SNF & & & 170 & PCI & 50 & GOOD & POOR \\
\hline 15-May-97 & $\mathrm{B3}$ & MO408 & 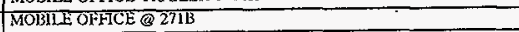 & DYN & GPF & 988 & 2002 & 258 & PC1 & 17 & MARGINAL & POOR \\
\hline 15-May-97 & $\mathrm{E}_{3}$ & MO410 & MOIIILE OFFCE Q $271 \mathrm{~B}$ & BWHC & B-PLÄNT & 1986 & & 250 & $\overline{\mathrm{PCI}}$ & 16 & GOOD & POOR \\
\hline 15-May-97 & $\mathrm{E3}$ & MO420 & MOBILE OFFCE (PIPEYARD) & DIESH & SNF & & & 170 & PCI & 50 & GOOD & POOR \\
\hline 15-May-97 & $\bar{E}$ & M0428 & MOBILE FELD OFFCE @ LERT & BWHC & PFP & 1990 & 2007 & 130 & PC1. & 50 & GOOD & POOR \\
\hline $15 \cdot$ May-97 & E3 & M0429 & MOBILE HIELD OHFCE Q LLERF & BWHC & PFP & 1990 & 2007 & 130 & PCT & so & $G O O D$ & POOR \\
\hline 15-May-97 & $\overline{E 3}$ & MO433 & MOBILE OFFCE/CHANGE OFFCE @ 271TMOBILE OFFCE (271T) & RFSH & T.PLANT & 1994 & 2017 & 180 & $\mathrm{PCl}$ & $\overline{12}$ & LKE NEW & ACCEPTABBLE \\
\hline $15 \cdot$ May $\cdot 97$ & $\overline{E 3}$ & MO434 & MOBILE OFFICE \& $209 \mathrm{E}$ & DYN & GPF & 1993 & 2007 & 172 & PCI & 12 & UKE NEW & POOR \\
\hline 15-May-97 & $\mathrm{E} 3$ & Mि0437 & MOBILE OFACE $272 \mathrm{WA}$ & RFSH & SWM & 1995 & & 172 & $\mathrm{PC1}$ & 25 & IIKE NEW & MARGINAL \\
\hline $15 \cdot$ May -97 & $\mathrm{E}_{3}$ & MO438 & MOBILE OFFICE 272WA & RFSH & SWM & 1995 & & 172 & PCI & 32 & ITKENEW- & MARGINAL \\
\hline $15 \cdot$ May-97 & E3 & MO442 & MOBILE OFFCE & DESH & SNF & & & 170 & $\mathrm{PC1}$ & 50 & GOOD & POOR \\
\hline $15-$ May-97 & $\mathrm{E}^{3}$ & MO459 & WOMEN'S CHANGE TRAILER & RFSH & TFPLANT & 1996 & & & $\overline{\mathrm{PCI}}$ & $\overline{12}$ & LIKE NEW & ACCEPTABLE \\
\hline 15-May-97 & $\mathrm{E}^{3}$ & MOS35 & MOBILE OFFICE $(1155 \mathrm{~N})$ & RFSH & swM & 1978 & & 120 & PCI & 7 & MARGINAL & MARGINAL \\
\hline 15-May-97 & $\mathrm{E} 3$ & MO536 & MOIBLE STORAGE (1129N) & DYN & GPF & 1979 & 2007 & 120 & PCI & 5 & MARGINAL & POOR \\
\hline $15-$ May-97 & E3 & MOS42 & MOBLLE OFFICE @ $202 A\left(A T T^{\circ} D / D^{\prime} D\right.$ MO3S5) & DYN & GPF & 1974 & 2002 & 120 & $\mathrm{PCl}$ & il & MARGINAL & POOR \\
\hline 15-May-9? & E3 & MOS60 & MOBILE OFFCE @ UNSECURED CORE AREA & DYN & GPF & 1979 & 2002 & 156 & $\mathrm{PC1}$ & 8 & MARGINAL & POOR \\
\hline 15-May-97 & E3 & M0656 & MOBILE OFFCE TRAILER & DYN & GPF & 1967 & 2007 & -9 & PC1 & 4 & MARGINAL & POOR \\
\hline 15:May-97 & $\mathrm{E} 3$ & MO744 & MOBILE OFFICE @ TEDF & RFSH & LEF & 1994 & 2007 & 172 & $\mathrm{PCl}$ & 15 & UKENEW & POOR \\
\hline 15-May-97 & $E_{3}^{3}$ & M0745 & MOBLE OFHCE @ TEDF & RFSH & LEF & 1994 & 2007 & 172 & $\mathrm{PCI}$ & $\overline{13}$ & UKE NEW & POOR \\
\hline $15-$ May-97 & E3 & MO834 & MOBILE OFFICE & BWHC & PFP & 1970 & 2007 & 70 & PCI & 9 & MARGINAL & POOR \\
\hline 15-May-97 & $\mathrm{E} 3_{3}$ & MO838 & MOBILE OFFCE @ 4TH \& BALTIMORE & DYN & $\overline{G P F}$ & 1978 & 2002 & 112 & $\overline{F C I}$ & $\sqrt{13}$ & POOR & POOR \\
\hline 15-May-97 & E3 & MO839 & 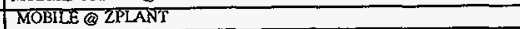 & BWHC & PFP & 1970 & 2007 & 70 & PC1 & 9 & MARGINAL & POKR \\
\hline 15-May-97 & $\mathrm{E} 3$ & MO863 & OFFLCE/LUNCHROOM TRAILER Q $225 \mathrm{~B}$ & BWHC & WESF & 1982 & 2017 & 147 & $\mathrm{PCl}$ & 8 & MARGINAL & POOR \\
\hline 15-May-97 & E3 & MO892 & MOBILE OFFCE WOO $271 \mathrm{~T}$ & RFSH & T-PLANT & 1977 & 2007 & 125 & PC1 & 31 & MARGINAL & ACCEPTABLE \\
\hline 15-May-97 & $\overline{E 3}$ & MO907 & OFFCE TRAILER @ 1722K MOBILE OFFCE TRAILER 1722K & DESH & SNF & & & 170 & PCI & 50 & GOOD & POOR \\
\hline 15-May-97 & $E^{3}$ & MOg22 & OFFICECHANGE TRAILER Q 2703E & DYN & GPF & 1977 & 2002 & 125 & PCI & 10 & MARGINAL & POOR \\
\hline 15-May-97 & $\mathrm{E}^{3}$ & MO923 & MOBILE OFFCE (1126N) & DESH & SNF & & & 170 & PCI & 50 & GOOD & POOR \\
\hline 15-May-97 & E3 & M0924 & MOBILE OFFCE $8202 \mathrm{~S}$ & DYN & GPF & 1977 & 2007 & 125 & PC1 & 10 & MARGINAL & POOR \\
\hline 15-May-97 & E3 & MO928 & MOBILE OFFCE Q 1723K (FKA 1123N) & DESH & SNF & & & 170 & PC1 & 50 & GOOD & POOR \\
\hline
\end{tabular}




\begin{tabular}{|c|c|c|c|c|c|c|c|c|c|c|c|c|}
\hline $\begin{array}{l}\text { WHEN } \\
\text { COMPLY }\end{array}$ & $\begin{array}{l}\text { Exempt } \\
\text { Status }\end{array}$ & IDENTIFER & DESCRIPITON & CONTRA & Project & $\begin{array}{l}\text { YEAR } \\
\text { BUILT }\end{array}$ & $\begin{array}{l}\text { YEAR } \\
\text { SURPLUS }\end{array}$ & \begin{tabular}{|l|} 
AREA \\
SQH \\
METERS \\
\end{tabular} & $\begin{array}{l}\text { Perf. } \\
\text { Cat. }\end{array}$ & $\begin{array}{l}\text { TOTAL } \\
\text { OCCUP }\end{array}$ & $\begin{array}{l}\text { FACILTY } \\
\text { CONDITION } \\
\text { RATING } \\
\end{array}$ & $\begin{array}{l}\text { EXISIING } \\
\text { ANALYSIS } \\
\text { RATING }\end{array}$ \\
\hline 15-May-97 & $\overline{E 3}$ & M0931 & CHANGEIUNCHROOM (284E) & $\overline{\text { DYN }}$ & $\overline{\text { GPF }}$ & 1975 & 2002 & 133 & $\mathrm{PC} 1$ & 9 & MARGINAL & POOR \\
\hline 15-May-97 & 8 & M0936 & MOBILE OFFCE (222S) & DYN & GPF & 1977 & 2007 & 147 & PC1 & 5 & MARGINAL & POOR \\
\hline $15-$ May-97 & E3 & M0939 & MOBILE OFFICE (23452) & DYN & $\overline{G P F}$ & 1977 & 2007 & 62 & $\mathrm{PCI}$ & 4 & MARGINAL & POOR \\
\hline 15-May-97 & E3 & M0947 & MOBILE OFFCE $@ 2704 \mathrm{~S}$ & DYN & GPF & 1976 & 2007 & 112 & $\mathrm{PC} 1$ & 0 & MARGINAL & POOR \\
\hline 15-May-97 & E3 & M0948 & MOBILE OFFCE - 202A & DYN & GPF & 1975 & 2002 & 120 & $\mathrm{PC} 1$ & 6 & POOR & POOR \\
\hline 15-May-97 & $\mathrm{E3}$ & M0969 & MOBILE OFFCE MOBILE OFFICE & DESH & SNF & & & 170 & PC1 & 50 & 6001 & POOK \\
\hline 15-May-97 & E3 & MO991 & MOBILE OFFICE - TRAILER CORE AREA & DYN & GPF & 1975 & 2002 & 172 & $\mathrm{PC} 1$ & 12 & MARGINAL & POOR \\
\hline 15-May-97 & $E_{3}^{3}$ & MO994 & MOBILE OFFCE AT MO227/5 60 & DYN & GPF & 19975 & 2002 & 125 & PCI & 6 & MARGINAL & $\mathrm{POOR}$ \\
\hline 15-May-97 & B3 & MO995 & MOBILE OFFCE @ $271 \mathrm{~B}$ & BWHC & B-PLANT & 1986 & & 125 & PC1 & 80 & GOOD & POOR \\
\hline 15-May-97 & $\mathrm{E3}$ & M0996 & MOBILE OFFCE (272AW) & DYN & GPF & 1975 & 2002 & 125 & $\mathrm{PC1}$ & 14 & MARGINAL & POOR \\
\hline 15-May-97 & E3 & M0997 & MOBILE OFFCE \& $243 \mathrm{G}$ (GROU1) & DYN & $\overline{G P F}$ & 1975 & 2002 & 125 & $\mathrm{PC} 1$ & 7 & MARGINAL & POOR \\
\hline 15-May-97 & ES & 1979SNYDER & 1979 SNYDER & DYN & $\overline{\mathrm{GPF}}$ & 1994 & 2017 & 1632 & $\mathrm{PC}_{1}$ & 56 & UKE NEW & POOR \\
\hline 15-May-97 & ES & 2025E & PUREX UQUID EFFLUENT TREATMENT FACIUTY & RFSH & LEF & 1994 & 2025 & 3717 & PC1 & 50 & LKENEW & POOR \\
\hline 15-May-97 & ES & 2025EA & EFFLUENT TREATMENT OPERAMTON SUPPORT FACILTY & $\mathrm{RFSH}$ & LEF & 1994 & 2025 & 1208 & PCI & 60 & UKENEW & POOR \\
\hline 15-May-97 & ES & $222 \mathrm{SA}$ & CHEMMCALSTANDARDS/PROCESS DEV LABORATORY & $\mathrm{RFSH}$ & $222-5$ & 1981 & 2027 & 410 & PCI & 15 & MARGINAL & FOOR \\
\hline 15-May-97 & ES & 2261STEVENS & \begin{tabular}{|l|l|} 
OFFCE BUILDING \\
\end{tabular} & $\overline{D Y N}$ & GPF & 1994 & 2017 & $\$ 132$ & PCI & 220 & UKENEW & POOR \\
\hline 15-May-97 & ES & $2336 \mathrm{~W}$ & $\begin{array}{l}\text { WASTE RECEVING AND PROCESSINGHACIUTYWASTE } \\
\text { RECEIVING AND PROCESSING }\end{array}$ & $\mathrm{Rl}: \mathrm{SH}$ & WRAP & 1996 & $20 \overline{27}$ & 5000 & $\mathrm{PCI}$ & 36 & LIKE NEW & ACCEPTABLE \\
\hline 15-May-97 & ES & $234-5 \mathrm{ZA}$ & PFP CHANGE ROOM ADDITION & BWHC & PFP & 1992 & 2007 & 430 & PC1 & 50 & GOOD & POOR \\
\hline 15-May-97 & ES & 2420 TIVCN & \begin{tabular}{|l|}
2420 STEVENS \\
\end{tabular} & DYN & GPF & 1995 & 2022 & 8709 & $\mathrm{PCI}$ & 445 & UKE NEW & POOR \\
\hline 15-May-97 & ES & $2425 \mathrm{STCN}$ & 2425 STEVENS CENTER PLACE & DYN & GPF & 1990 & 2022 & 4132 & $\overline{P C 1}$ & 220 & GOOD & POOR \\
\hline 15.May-97 & $\mathrm{ES}$ & $2430 \mathrm{STVCN}$ & 2430 STEVENS CENTER PLACE & DYN & GPF & 1995 & $20 \overline{22}$ & 4416 & PC1 & $185^{-}$ & T.JKE NEW & POOR \\
\hline 15-May-97 & ES & $2440 \mathrm{STCN}$ & 2440 STEVENS CENTER PLACE & DYN & GPF & 1990 & 2022 & 9182 & $\mathrm{PC} 1$ & 475 & GOOD & POOR \\
\hline 15-May-97 & ES & 2702 & PFP OPERATIONS AND SUPPORT FACILTYY & BWHC & PFP & 1988 & & 1200 & $\mathrm{PC1}$ & 101 & GOOD & POOR \\
\hline 15-May-97 & ES & $2727 \mathrm{E}$ & SAFEGUARD AND SECURITY OFFCE & DYN & GPF & 1985 & 2017 & 1766 & $\mathrm{PC1}$ & 34 & MARGINAL & POOR \\
\hline 15-May-97 & ES & $2728 \mathrm{E}$ & PUMP STORAGE & DYN & GPF & 1985 & & 1766 & PC1 & 34 & MAR & GINAL \\
\hline 15-May-97 & ES & 274AW & OFFCE BUILDING & DYN & GPF & 1994 & 2017 & 836 & PC1 & 57 & UKE NEW & POOR \\
\hline 15-May-97 & ES & $2750 \mathrm{E}$ & WASTE MANAGEMENT SURY, AND OPERATING FACILITY & DYN & $\overline{G P F}$ & 1980 & 2017 & 8922 & $\overline{\mathrm{PC} 1}$ & 532 & GOOD & POOR \\
\hline 15-May-97 & ES & 275:E & OFFCE FACILTY & DYN & GPF & 1985 & 2007 & 1394 & PC1 & 83 & MARGINAL & POOR \\
\hline 15-May-97) & ES & 2752E & 200 EAST OFFTCE & DYN & $\overline{\mathrm{GPF}}$ & 1985 & 2007 & 1394 & $\mathrm{PCl}$ & 69 & MARGINAL & POOR \\
\hline 15-May-97 & E5 & $2753 \mathrm{E}$ & OFFICE BUILDING W/O 2750E & DYN & GPF & 1986 & 2007 & 1394 & $\mathrm{PC1}$ & 61 & GOOD & POOR \\
\hline 15-May-97 & E5 & $3707 \mathrm{D}$ & INFORMATION SERVICES BUILDING & $\overline{D Y N}$ & $\overline{\text { GPF }}$ & 1959 & 2007 & 797 & PCI & 25 & POOR & POOR \\
\hline 15-May-97 & E5 & 3790 & SECURITY OFFCE BUILDING & DYN & GPF & 1981 & 2027 & 1747 & $\mathrm{PC} 1$ & 73 & MARGINAL & POOR \\
\hline 15:May-97 & ES & 4706 & OFFCE BUILDING & DYN & GPF & 1983 & 2017 & 1735 & PC1 & 92 & MARGINAL & POOR \\
\hline 15-May.97 & ES & 4710 & FFTF OFFCE BUILDING & BWHC & FFTF & 1980 & & 3434 & $\mathrm{PCl}$ & 210 & MARGINAL & POOR \\
\hline 15-May-97 & ES & 4790 & PATROL HEADQUARTERS BUILDING & DYN & GPF & 1980 & 2017 & 391 & PC1 & 13 & MARGINAL & POOR \\
\hline 15-May-97 & E5 & $609 \mathrm{D}$ & TRALNING TOWER FACIUTY & DYN & GPF & 1985 & 2007 & 451 & PO1 & 40 & MARGINAL & POOR \\
\hline 15-May-97 & ES & 6266 & WASTE SAMMPLING AND CHARACTERIZATION FACILTYY & RFSH & HAS & 1993 & 2020 & 966 & PC1 & 45 & LURE NEW & VERIFIED \\
\hline 15-May-97 & ES & 6290 & CRANE \& RIGGING BUILDING & DYN & GPF & 1990 & 2017 & 7171 & PC1 & 10 & GOOD & POOR \\
\hline 15-May-97 & $\overline{E S}$ & 662 & PATROL TRAINING BUILDING Q PTA & DYN & GPF & 1982 & 2017 & 335 & $\overline{\mathrm{PCT}}$ & 10 & MARGINAL & POOR \\
\hline I5-May-97 & ES & MO037 & MOBILE OFFICE @ $222 \mathrm{~S}$ & DYN & GPF & 1979 & 2007 & 515 & $\mathrm{PC1}$ & 33 & MARGINAL & POOR \\
\hline
\end{tabular}




\begin{tabular}{|c|c|c|c|c|c|c|c|c|c|c|c|c|}
\hline $\begin{array}{l}\text { WHEN } \\
\text { COMPLYY }\end{array}$ & $\begin{array}{l}\text { Excmpt } \\
\text { Status }\end{array}$ & IDENTIFER & DESCRTPTION & CONTRA & Project & $\begin{array}{l}\text { YKEAR } \\
\text { BUILT }\end{array}$ & $\begin{array}{l}\text { YEAR } \\
\text { SURPLUS }\end{array}$ & $\begin{array}{l}\text { ARIAA } \\
\text { SQH } \\
\text { METERS }\end{array}$ & $\begin{array}{l}\text { Perf. } \\
\text { Cat. }\end{array}$ & $\begin{array}{l}\text { TOTAL } \\
\text { OCCUP }\end{array}$ & $\begin{array}{l}\text { FACITTY } \\
\text { CONDITION } \\
\text { RATING }\end{array}$ & $\begin{array}{l}\text { EXISTING } \\
\text { ANALYSIS } \\
\text { RATING }\end{array}$ \\
\hline 15-Mny-97| & $\overline{E S}$ & $\overline{M O 043}$ & MOBILE OFFCE (DOSIMETRY) @ 2750E & $\overline{\text { DYN }}$ & $\overline{\text { GPF }}$ & 1979 & 2007 & 343 & $\overline{\mathrm{PCl}}$ & 15 & MARGINAL & POOR \\
\hline 15-May-97 & ES & M0047 & MOBILE OFFCE Q $2101 \mathrm{M}$ & DYN & GPF & 1981 & 2007 & 1116 & $\mathrm{PCl}$ & 65 & MARGINAL & POOR \\
\hline 15-May-97 & E5 & MO234 & MOBILE OFFCEE @ 2750E & DYN & GPF & 1986 & 2007 & 859 & $\mathrm{PCI}$ & 46 & GOOD & POOR \\
\hline 15-May-97 & ES & MO276 & MOBILE OFFICE $@ 2753$ E & DYN & GPF & 1992 & 2007 & 1374 & PCI & 59 & UKE NEW & POOR \\
\hline 15-May-97 & E5 & MO277 & MOBILE OFFICE @ 2753E & DYN & GPF & 1992 & 2007 & 1374 & PCI & 93 & UKE NEW & POOR \\
\hline 15-May-97 & ES & MO278 & MOBILE OFFCE W/O $275 W$ MOBILE OFHCE & RFSH & SWM & 1995 & & 859 & PCI & 60 & DKENEW & MARGINAL \\
\hline 15-May-97| & ES & MO279 & MOBILE OFFCE W/O $275 \mathrm{~W}$ & RFSH & SWM & 1995 & & 859 & PCI & 60 & LKE NEW & MARGINAL \\
\hline \begin{tabular}{|l|}
$15 \cdot$ May-97 \\
\end{tabular} & $\overline{E S}$ & MO280 & MOBILE OFFCE @ WSCF STTE & $\overline{D Y N}$ & GPF & 1992 & 2007 & 859 & PCI & 50 & GOOD & POOR \\
\hline 15-May-97 & ES & MO281 & MOBILE OFFCE @ 272WA & DYN & GPF & 1992 & 2022 & 1374 & PCI & 88 & UKE NEW & POOR \\
\hline 15-May-97 & ES & MO285 & MOB1LEOHFCE@ 2733E & DYN & GPF & 1994 & 2607 & 7030 & $\mathrm{PCI}$ & 82 & LIKENEW & POOR \\
\hline $\begin{array}{l}\mid 15-\text { May- }-97 \\
\end{array}$ & $E 5$ & MO287 & MOBILE OFFICE (3) $275 \mathrm{~W}$ & DYN & GPF & 1993 & 2007 & 1030 & $\mathrm{PCI}$ & 45 & LKE NEW & POOR \\
\hline \begin{tabular}{|l|}
$15-$ May-97 \\
\end{tabular} & BS & M0291 & MOBILE OFFICE NEAR $2704 \mathrm{~S}$ & DYN & GPF & 1994 & 2007 & 859 & $\overrightarrow{\mathrm{PCl}}$ & 65 & LKE NEW & POOR \\
\hline 15-May-97 & ES & MO292 & MOBILE OFFICE & DYN & GPF & 1994 & 1999 & 859 & $\mathrm{PCl}$ & 50 & UKE NEW & POOR \\
\hline 15-May-97 & $\mathrm{ES}$ & M0406 & CHANGEJLONCHROOM TRAILER @ $2724 \mathrm{WB}$ & DYN & GPF & 1982 & 2007 & 258 & PC1 & 5 & MARGINAL & POOR \\
\hline 15-May-97| & E5 & M0407 & MOBILE OFFICE @ $2101 \mathrm{M}$ & DYN & GPF & 1983 & 2007 & 429 & $\mathrm{PC1}$ & 23 & MARGINAL & POOR \\
\hline 15-Mny-97 & ES & MO413 & MOBILE OFFCE @ $2750 \mathrm{E}$ & DYN & GPF & 1984 & 2007 & 687 & PCI & 14 & MARGINAL & POOR \\
\hline 15-May-97 & BS & MO720 & MOBLLE OFFCE O 272WA & $\overline{\mathrm{RFSH}}$ & SWM & 1994 & & 1347 & PCI & 113 & UKE NEW & MARGINAL \\
\hline 15-May-97 & ES & M0721 & MOBILE CHANGE FACILTY (3) 272WA & RFSH & sWM & 1994 & & 343 & PCI & 30 & DKENEW & MARGINAL \\
\hline 15-May-97 & ES & M0743 & MOBLLE SHOP/OFFCE @ 272WA & RFSH & SWM & 1994 & 2014 & 515 & PCI & 25 & URE NEW & MARGINAL \\
\hline 15-May-97 & E8 & 1167 & STORAGE BUILDING & DYN & GPF & 1953 & 2002 & 3346 & $\mathrm{PCl}$ & 56 & POOR & POOR \\
\hline 15-May-97 & E8 & 1168 & CYLNDER STORAGE BLDGG & DYN & GPF & 1953 & 2002 & 520 & $\mathrm{PCl}$ & 3 & $\mathrm{POOR}$ & POOR \\
\hline T5-May-97 & E8 & $1706 \mathrm{KE}$ & WATER STUUIES SEMIWORKS FACILITY & DESH & SNF & I955 & 2002 & 1005 & $\mathrm{PCl}$ & & MARGINAL & POOR \\
\hline 15-May-97 & E8 & $1717 \mathrm{~K}$ & MANTENANCE TRANSPORTATTON SHOP & DESH & SNF & 1955 & 2002 & 992 & $\mathrm{PC} 1$ & 50 & GOOD & POOR \\
\hline 15-May-97 & E8 & 190KE & HIGH BAY STORAGE AREA & DESH & SNF & 1955 & 2002 & 2400 & $\mathrm{FC1}$ & $\frac{1}{1}$ & MARGINAL & POOR \\
\hline 15-Mny-97 & E8 & $2704 \mathrm{~W}$ & OFFCE BUIDING & DYN & GPF & 1944 & 1998 & 600 & $\mathrm{PCI}$ & 22 & POOR & POOR \\
\hline 15-May-97 & $E 8$ & $2723 \mathrm{~W}$ & MASK LAUNDRY AND OFHCE BUILDING & DYN & GPF & 1944 & 1999 & 420 & PC1 & 9 & POOR & POOR \\
\hline 15-May-97 & E8 & 275UR & CHEMICAL STORAGE WAREHOUSE & DYN & GPF & 1952 & 2002 & 393 & $\mathrm{PCl}$ & 2 & POOR & $\overline{\text { POOR }}$ \\
\hline 15-May-97| & Es & $313 \mathrm{~N}$ & $313-\mathrm{N}$ & BWHC & FFF & 1960 & 1999 & 4258 & $\mathrm{PC1}$ & 25 & POOR & POOR \\
\hline 15-May-97| & E8 & 333 & N FUELS BUILDING Chromium Treatment Tanks (2 Tanks) & BWHC & FFF & 1961 & 1999 & 5854 & $\mathrm{PCI}$ & 25 & POOR & POOR \\
\hline 15-May-97| & Ex & $340^{\circ}$ & RETENITON AND NEUTRALZZATTON & RFSH & LEF & $195 \overline{2}$ & 1999 & 416 & PC1 & $-\frac{1}{2}$ & POOR & POOK \\
\hline 15-May-97 & E8 & 4702 & OFFCE BUILDINGOFFICE BUILDING & DYN & $\overline{G P F}$ & 1948 & 2002 & 1952 & $\mathrm{PC1}$ & 2 & MARGINAL & POOR \\
\hline 15-May-97 & E8 & $622 \mathrm{G}$ & ATMOSPHERE SCIENCE ANNEX & DYN & $\overline{G P F}$ & 1944 & 1999 & 348 & $\overline{\mathrm{PCl}}$ & 14 & POOR & POOR \\
\hline
\end{tabular}


HNF-SP-1175

APPENDIX C

COMPLIANCE BASELINE AND PRIORITIZATION SCHEDULE FOR EXISTING BUILDINGS AND STRUCTURES REQUIRING

NATURAL PHENOMENA HAZARDS MITIGATION 
HNF-SP-1175

This page intentionally left blank. 
APPENDIX C. COMPLIANCE BASELINE AND PRIORITIZATION SCHEDULE FOR EXISTING BUILDINGS AND STRUCTURES REQUIRING NPH EVALUATION

TOTAL NON-EXEMPT ASSETS $=860$

\begin{tabular}{|c|c|c|c|c|c|c|c|c|c|c|c|c|}
\hline $\begin{array}{l}\text { EVALU } \\
\text { SCHED }\end{array}$ & $\begin{array}{l}\text { PRIOITY } \\
\text { SCORE }\end{array}$ & IDEMTIVIER & DESCRIPTION & CONTRA & PROJECT & $\begin{array}{l}\text { YEAR } \\
\text { BULLT }\end{array}$ & $\begin{array}{l}\text { YEAR } \\
\text { SURPLUS }\end{array}$ & $\begin{array}{l}\text { AREA SQH } \\
\text { METERS }\end{array}$ & $\begin{array}{c}\text { PERF.C } \\
\text { AT. }\end{array}$ & $\begin{array}{l}\text { TOTAL } \\
\text { OCCUP }\end{array}$ & $\begin{array}{l}\text { FACLLTYY } \\
\text { CONDITION } \\
\text { RATING }\end{array}$ & $\begin{array}{c}\text { EXISTING } \\
\text { ANALYSIS } \\
\text { RATING }\end{array}$ \\
\hline FY 98 & 30 & 234.52 & PLUTONIUM FABRICATION FACILITY & BWHC & PFP & 1949 & 20007 & 18500 & PC3 & 101 & POOR & MARGNAL \\
\hline FY 98 & 28 & $609 \mathrm{~A}$ & FIRE STATION - 200EN & DYN & GPF & 1965 & 1999 & 767 & $\mathrm{PC2}$ & 108 & POOR & POOR \\
\hline FY 98 & 23 & $3709 \mathrm{~A}$ & FIRE STATION & DYN & GPF & 1964 & 2002 & 72 & PC2 & 50 & POOR & POOR \\
\hline FY 98 & 23 & 609 & FIRE STATION - $100 \mathrm{~N}$ & DYN & GPF & 1961 & 1999 & 992 & $\mathrm{PC2}$ & 14 & POOR & POOR \\
\hline FY 98 & 21 & $2101 \mathrm{MS}$ & SPARE PARTS WAREHOUSE & DYN & GPF & 1944 & 2007 & 15730 & $\mathrm{PCl}$ & 128 & $\mathrm{POOR}$ & POOR \\
\hline FY 98 & 21 & 2225 & CONTROL LABORATORY & RFSH & 222.5 & 195I & 2027 & 3700 & $\mathrm{PCI}$ & 140 & POOR & POOR \\
\hline FY 98 & $2 !$ & $236 \mathrm{Z}$ & PLUTONIUM RECLAMATION FACILTTY/BUILDING & BWWC & PFP & 1963 & & 1780 & $P C 3$ & 9 & POOR & MARGINAL \\
\hline FY 98 & $2 !$ & 27362 & PLUTONIUM STORAGE BUILDING & BWHC & PFP & 1920 & 2047 & 332 & PC3 & 30 & POOR & VERIFIABLE \\
\hline FY 98 & 21 & 324 & 324 SUPPORT WAREHOUSE & BWHC & FFP & 1966 & 2002 & 9755 & $\mathrm{PC} 3$ & 150 & MARGINAL & VEREFIABLE \\
\hline FY 98 & 21 & 327 & $\begin{array}{l}\text { POST IRRADIATION TEST } \\
\text { LABORATORYRADIOMETTALURGY }\end{array}$ & BWIIC & FFF & 1953 & & $234 !$ & $\mathrm{PC3}$ & 63 & POOR & VERIFIABLE \\
\hline FY 98 & 21 & 703 & OFFICE BUILDING, 840 NORTHGATE & DYN & GPF & 1952 & 2017 & 2447 & $\mathrm{PCI}$ & 115 & POOR & POOR \\
\hline FY 98 & 21 & 82SJADWIN & FEDERAL BUILDING & DYN & GPF & 1965 & 2047 & 6583 & $\mathrm{PCl}$ & 1000 & POOR & POOR \\
\hline FY 98 & 20 & $224 \mathrm{~T}$ & (TRUSAF)WASTE DRUM X-RAY BUILDING & RFSH & swM & 1945 & & 3002 & PC3 & 0 & POOR & MARGINAL \\
\hline FY 98 & 20 & $242 Z$ & $\begin{array}{l}\text { WASTE TREATMENT FACILITY, MONTRORING } \\
\text { BUILDING }\end{array}$ & BWHC & PFP & 1960 & & 100 & PC3 & 0 & POOR & MARGINAL \\
\hline FY 98 & 18 & $291 \mathrm{BC}$ & EXHAUST AIR FILTER CELLS I AND 2 & BWISC & B.PLANT & 1965 & & 160 & $\mathrm{PC2}$ & 0 & POOR & MARGINAL \\
\hline FY 98 & 18 & $291 \mathrm{BD}$ & AIR CONTROL HOUSE & BWIiC & B.PLANT & 1970 & & 170 & $\mathrm{PC2}$ & 0 & POOR & MARGINAL \\
\hline FY 98 & 18 & 335 & SODIUM TEST FACILTYY & BWHC & FFTF & 1969 & & 620 & $\mathrm{PC2}$ & 0 & POOR & POOR \\
\hline FY 98 & 18 & 47045 & 400 AREA FIRE STATION & DYN & GPF & 1973 & 2007 & 72 & PC2 & 15 & MARGINAL & POOR \\
\hline FY 98 & 17 & 2322 & WASTE INCINERATOR FACIL,TTYRUULLDING & BWHC & PFP & 1959 & & 200 & PC3 & 9 & POOR & VERIFIABLE \\
\hline FY 98 & 16 & IISSJADWIN & 1135 JADWIN BLDG (RICHLAND) OFFICE BUILDING & DYN & GPF & 1970 & 2017 & 826 & $\mathrm{PCI}$ & 76 & POOR & POOR \\
\hline FY 98 & 16 & 1163 & CENTRAL WAREHOUSE PROCUREMENT OFFICES & DYN & GPF & 1987 & 2022 & 16894 & $\mathbf{P C 1}$ & 340 & MARGINAL & POOR \\
\hline FY 98 & 16 & $221 \mathrm{~B}$ & PROCESS TREATMENT BUILDING & BWHC & B.PLANT & 1945 & & 7668 & PC2 & 0 & POOR & VERIFIABLE \\
\hline FY 98 & 16 & $221 \mathrm{~T}$ & T-PLANT CANYON BUILDING & RFSH & T.PLANT & 1944 & 2027 & 5370 & $\mathbf{P C 1}$ & 62 & POOR & POOR \\
\hline FY 98 & 16 & 2228 & OFFICE BUILDING & BWHC & B.PLANT & 1943 & & 681 & $\mathbf{P C l}$ & 10 & POOR & POOR \\
\hline FY 9 & 16 & $271 \mathrm{~B}$ & SERVICE AND OFFICE BUILDING & BWHC & B.PLANT & 1945 & & 2820 & $\mathrm{PCl}$ & 10 & POOR & VERIFIABLE \\
\hline FY 98 & 16 & $271 \mathrm{~T}$ & OFFICE AND SERVICE BUILDING & RFSH & T-PLANT & 1944 & 2007 & 720 & $\mathrm{PCI}$ & 100 & POOR & POOR \\
\hline FY 98 & 16 & $272 \mathrm{w}$ & MACHINE SHOP & DYN & GPF & 1944 & 2012 & 1547 & PC1 & 40 & POOR & POOR \\
\hline FY 98 & 16 & $27362 \mathrm{~B}$ & $\begin{array}{l}\text { PLUTONIUM STORAGE SUPPORT } \\
\text { FACIITYY/BUILDNG. }\end{array}$ & BWHC & PFP & 1981 & 2047 & 1100 & $\mathrm{PC3}$ & 40 & MARGINAL & VERIFIABLE \\
\hline FY 98 & 16 & $277 \mathrm{~W}$ & FABRICATION SHOP & DYN & GPF & 1944 & 2012 & 2710 & $\mathrm{PC} 1$ & 60 & POOR & POOR \\
\hline
\end{tabular}




\begin{tabular}{|c|c|c|c|c|c|c|c|c|c|c|c|c|}
\hline $\begin{array}{l}\text { EVALU } \\
\text { SCHED }\end{array}$ & $\begin{array}{l}\text { PRLOTYY } \\
\text { SCORE }\end{array}$ & IDENTIFER & DESCRIPTION & CONTRA & PROJECT & $\begin{array}{l}\text { YEAR } \\
\text { BUILT }\end{array}$ & $\begin{array}{l}\text { YEAR } \\
\text { SURPLUS }\end{array}$ & $\begin{array}{l}\text { AREA SO } f \\
\text { METERS }\end{array}$ & $\begin{array}{c}\text { PERF.C } \\
\text { AT. }\end{array}$ & $\begin{array}{l}\text { TOTAL } \\
\text { OCCUP }\end{array}$ & $\begin{array}{l}\text { FACILTTY } \\
\text { CONDITION } \\
\text { RATING }\end{array}$ & $\begin{array}{l}\text { EXISTING } \\
\text { ANALYYSS } \\
\text { RAYING }\end{array}$ \\
\hline FY 98 & 16 & $291 \mathrm{~B}$ & $\begin{array}{l}\text { SAND FLTER \& STACK, EXHAUST AIR CONTROL } \\
\text { BUTLDING }\end{array}$ & BWHC & B-PLANT & 1969 & & 31 & $\mathrm{PC2}$ & 0 & POOR & VERIFIAELE \\
\hline FY 98 & 16 & 29121 & STACK, $2345 Z, 2362$, AND 242Z MAN & BWHC & PFP & 1949 & & 130 & PC3 & 0 & POOR & VERIFIABLE \\
\hline FY 98 & 16 & 305 & ENGINEERING TESTING FACILTYY & DYN & GPF & 1944 & & 1428 & $\mathrm{PCl}$ & 29 & POOR & POOR \\
\hline FY 98 & 16 & $306 \mathrm{E}$ & FABRICATION AND TEST LAB & DYN & GPF & 1956 & & 3826 & PC1 & 40 & POOR & POOR \\
\hline FY 98 & 16 & 328 & ENG. SERVICES \& SAFETY BUILDING & DYN & GPF & 1953 & 2012 & 3885 & $\mathrm{PCl}$ & 100 & POOR & POOR \\
\hline FY 98 & 16 & $3717 \mathrm{~B}$ & STANDARDS LABORATORY & DYN & GPF & 1951 & & 827 & $\mathrm{PCl}$ & 13 & POOR & POOR \\
\hline FY 98 & 16 & 798 & RADIOSURGERY FACILITY & DYN & GPF & 1967 & 2022 & 296 & $\mathrm{PC1}$ & 10 & POOR & POOR \\
\hline $\mathrm{FY} 98$ & 15 & 616 & $\begin{array}{l}\text { NONRADLOACTNE IIAZARDOUS CHEMICAL } \\
\text { WASTE FACILTYY }\end{array}$ & RFSH & SWM & 1986 & & 716 & $\mathrm{PC3}$ & 0 & MARGINAL & MARGINAL \\
\hline FY 98 & 14 & $242 \mathrm{~A}$ & EVAPORATOR & RFSH & $242 A$ & 1977 & 2027 & $m$ & $\mathrm{PC2}$ & 14 & MARGINAL & VERIFIED \\
\hline FY 98 & 14 & 3378 & 337 HIGH.BAY AND SERVICE WING & BWHIC & FFTF & 1973 & & 3446 & $\mathrm{PC2}$ & 2 & MARGINAL & POOR \\
\hline FY 98 & 14 & 405 & FFTF REACTOR BUILDING & $\mathrm{BWHC}$ & FFTF & 1978 & & 8002 & PC2 & 45 & MARGINAL & VERIFIABLE \\
\hline FY 98 & 14 & $4621 \mathrm{E}$ & ALXILIARY EQUIPMENT BUILDING,EAST & BWHC & FFTF & 1978 & & 1582 & $\mathrm{PC2}$ & 20 & MARGINAL, & VERIFIABLE \\
\hline FY 98 & 13 & $291 \mathrm{BF}$ & AIR FILTER CELLFOURTH & BWHC & B-PLANT & 1975 & & 106 & $\mathrm{PC} 2$ & 0 & MARGINAL & MARGINAL, \\
\hline FY 98 & 13 & $291 \mathrm{BH}$ & INSTRUMENT SERVICE BUILDING & BWHC & B-PLANT & 1980 & & 184 & PC2 & $\circ$ & MARGINAL & MARGINAL \\
\hline FY 98 & 13 & $3718 \mathrm{M}$ & SODIUM STORAGE FACILITY & BWHC & FFTF & 1973 & & 187 & PC2 & 0 & MARGiNaL. & POOR \\
\hline FY 98 & 13 & $4713 \mathrm{C}$ & WAREHOUSE & BWHC & FFTF & 1978 & & 374 & PC2 & 0 & MARGINAL & POOR \\
\hline FY 98 & 12 & 10SKE & REACTOR FACILTYY/ BUILDING & DESH & SNF & 1955 & 2002 & 2600 & PC3 & so & GOOD & VERIFIABLE \\
\hline FY 98 & 12 & $105 \mathrm{KW}$ & REACTOR FACILTTY/ BUILDING & DESH & SNF & 1955 & 3002 & 2600 & PC3 & so & GOOD & VERIFIED \\
\hline FY 98 & 12 & $274 \mathrm{E}$ & LANDLORD AND MAINTENANCE SHOP & DYN & GPF & 1944 & 2007 & 352 & PCI & 8 & POOR & POOR \\
\hline $\mathrm{FY} 98$ & 12 & 27SE & CARPENTER SHOP BUILDING & DYN & GPF & 1944 & 2007 & $3 n$ & $\mathrm{PCI}$ & 8 & POOR & POOR \\
\hline FY 98 & 12 & 2912 & $\begin{array}{l}\text { EXHAUST AIR FILTER STACK BUTLDING, EXHAUST } \\
\text { FANS \& STACK }\end{array}$ & BWHC & PFP & 1949 & 2007 & 90 & $\mathrm{FCl}$ & 9 & POOR & POOR \\
\hline FY 98 & 12 & 309 & SP-100 GES TEST FACILITY, OFFICES AND SHOPS & BWHC & FFF & 1900 & & 4340 & PCI & 10 & POOR & MARGINAL \\
\hline FY 98 & 12 & 3700 & PAINT SHOP & DYN & GPF & 1944 & 2007 & 284 & $\mathrm{PCl}$ & 5 & POOR & POOR \\
\hline FY 98 & 12 & 3713 & CARPENTER SHOP & DYN & GPF & 1943 & 2007 & 446 & $\mathrm{PCl}$ & 6 & POOR & POOR \\
\hline FY 98 & 12 & 437 & MAINTENANCE AND STORAGE FACLLTY (MASF) & BWHC & FFTF & 1980 & & 5595 & PC2 & $s$ & MARGNAL. & MARGINAL \\
\hline FY 98 & 11 & 1171 & MAINTENANCE OFFICEJSHOP & DYN & GPF & 1954 & 2007 & 8702 & $\mathrm{PCI}$ & 92 & MARGINAL & ACCEPTABLE \\
\hline FY 98 & 11 & 1802TD & $\begin{array}{l}\text { SKYPARK TRADE CENTER (18O2TERMINAL } \\
\text { DR.)OFFICE }\end{array}$ & DYN & GPF & 1977 & 2012 & 460 & $\mathrm{PCl}$ & 76 & MARGINAL & POOR \\
\hline FY 98 & 11 & 1804TD & $\begin{array}{l}\text { TECH TRAINING CEATER (1804TERMINAL, } \\
\text { DR.OOFFICE BUIIDING }\end{array}$ & DYN & GPF & 1977 & 2012 & 460 & PC1 & 36 & MARGINAL & POOR \\
\hline FY 98 & 11 & 1806TD & \begin{tabular}{|l} 
TECH TRANING CENTER (1800TERMINAL \\
DR.OFFICE BUILDING
\end{tabular} & DYN & GPF & 1977 & 2012 & 460 & $\mathrm{PCl}$ & 76 & MARGINAL & POOR \\
\hline FY 98 & 11 & 1808TD & $\begin{array}{l}\text { TECH TRAINING CENTER (1808TERMINAL } \\
\text { DR.JOFFICE BULDING }\end{array}$ & DYN & GPF & 1977 & 2012 & 460 & PCI & 76 & MARGDNAL & POOR \\
\hline
\end{tabular}




\begin{tabular}{|c|c|c|c|c|c|c|c|c|c|c|c|c|}
\hline $\begin{array}{l}\text { EVALU } \\
\text { SCHED }\end{array}$ & $\begin{array}{l}\text { PRIORTY } \\
\text { SCORE }\end{array}$ & IDENTIFER & DESCRIPTION & CONTRA & PROJECT & $\begin{array}{l}\text { YEAR } \\
\text { BUILT }\end{array}$ & $\begin{array}{l}\text { YEAR } \\
\text { SURPLUS }\end{array}$ & $\begin{array}{l}\text { AREA SOF } \\
\text { METERS }\end{array}$ & $\begin{array}{c}\text { PERF.C } \\
\text { AT. }\end{array}$ & $\begin{array}{l}\text { Toral } \\
\text { Occup }\end{array}$ & $\begin{array}{c}\text { FACILTTY } \\
\text { CONDTION } \\
\text { RATING }\end{array}$ & $\begin{array}{l}\text { EXISTING } \\
\text { ANALYSIS } \\
\text { RATING }\end{array}$ \\
\hline FY 98 & 11 & 1810TD & $\begin{array}{l}\text { TECH TRAINING CENTER (18IOTERMINAL } \\
\text { DR.,OFFICE BUILDING }\end{array}$ & DYN & GPF & 197 & 2012 & 400 & $\mathrm{PCl}$ & 76 & MARGNAL & POOR \\
\hline FY 98 & 11 & 1812TD & $\begin{array}{l}\text { TECH TRALNING CENTER (181ZTERMINAL } \\
\text { DR.)OFFICE BUILDING }\end{array}$ & DYN & GPF & 1977 & 2012 & 460 & PCI & 76 & MARGINAL & POOR \\
\hline FY 93 & 11 & 1814TD & $\begin{array}{l}\text { TECH TRAINING CENTER (181GTERMINAL } \\
\text { DR.)OFFICE BUILDING }\end{array}$ & DYN & G:PF & 197 & 2012 & 460 & $\mathrm{PCl}$ & 76 & MARGINAL & POOR \\
\hline FY 98 & ii) & $1816 \mathrm{TD}$ & 1816 TERMINAL DR.OFFICE BUILDING & DYN & GPF & $19 n$ & 2012 & 460 & $\mathrm{PCI}$ & 76 & MARGINAL & POOR \\
\hline FY98 & 31 & $1818 \mathrm{TD}$ & 1818 TERMINAL, DR.OFFICE BUILDDNG & DYN & GPF & 197 & 2012 & 460 & $\mathrm{PCI}$ & 76 & MARGINAL & POOR \\
\hline FY98 & 11 & $1820 \mathrm{TD}$ & 1820 TERMINAL DR. OFFICE BUILDING & DYN & GPF & 1977 & 2012 & 460 & $\mathrm{PC} 1$ & 36 & MARGINAL & POOR \\
\hline FY 9 & 11 & 2061 BTLR-LP & $\begin{array}{l}2061 \text { BUTLER LOOP, RICHLAND IR:M MODEL SHOP } \\
\text { BUILDNG }\end{array}$ & DYN & GPF & 1980 & 2012 & 630 & $\mathrm{PCI}$ & 18 & MARGINAL & POOR \\
\hline FY 98 & 11 & $2258 \mathrm{BE}$ & ENCAPSLLATION REPAIR SHOP & BWHC & WESF & 1977 & 2017 & 297 & $\mathrm{PCI}$ & & MARGINAL & POOR \\
\hline FY98 & 11 & $2401 \%$ & MXED WASTE STORAGE BUILDNG. & RESHI & SWM & 1988 & 2009 & 372 & $\mathrm{PC} 3$ & 0 & GOOD & MARGINAL \\
\hline FY98 & 11 & $2402 \mathrm{w}$ & MDEED WASTE STORAGE FACILTTY,2402W & RFSH & swM & 1989 & 2009 & 32 & $\mathrm{PC3}$ & 0 & GOOD & MARGNAL \\
\hline FY98 & II & $2302 \mathrm{WB}$ & MDED WASTE STORAGE FACILTYY 2402WB & RFSH & SWM & 1990 & 2010 & 32 & PC3 & 0 & GOOD & MARGINAL \\
\hline FY 98 & 11 & $2402 \mathrm{WC}$ & MLEED WASTE STORAGE FACILTYZ402WC & RFSH & SWM & 1990 & 2010 & $3 \pi$ & $\mathrm{PC3}$ & 0 & GO0D & MARGINAL \\
\hline FY98 & 31 & $2002 \mathrm{WD}$ & MLEDD WASTE STORAGE FACILITY2402WD & RFSH & SWM & 1900 & 2010 & 372 & $\mathrm{PC3}$ & 0 & GOOD & MARGINAL \\
\hline FY 98 & 11 & 2402WE & MLXED WASTE STORAGE FACILTYY202WE & RFSH & swM & 1990 & 2010 & $3 n$ & $\mathrm{PC} 3$ & 0 & GOOD & MARGINAL \\
\hline FY 98 & 11 & $2402 \mathrm{WF}$ & MIXED WASTE STORAGE FACLLTY $2402 \mathrm{WF}$ & RFSH & SWM & 1990 & 2010 & 372 & $\mathrm{PCO}$ & 0 & GOOD & MARGINAL \\
\hline FY 98 & 11 & 2002WG & RMW STORAGE FACLLTY $\# T$ & RFSH & SWM & 1990 & 2010 & 32 & $\mathrm{PC3}$ & 0 & GOOD & MARGINAL \\
\hline FY 98 & 11 & $2202 \mathrm{WH}$ & RMW STORAGE FACLITY : & RFSH & sWM & 1990 & 2010 & 32 & PC3 & 0 & GO00D & MARGINAL \\
\hline FY 98 & 11 & $2002 \mathrm{WI}$ & RMW STORAGE FACILITY \# & RFSH & sWM & 1990 & 2010 & 372 & PC3 & 0 & GOOD & MARGINAL \\
\hline FY 98 & II & $2402 \mathrm{WJ}$ & RMW STORAGE FACILITY & RFSH & SWM & 1990 & 2010 & 372 & PC3 & 0 & GOOD & MARGNAL \\
\hline FY 98 & "1 & $2002 \mathrm{WK}$ & RMW STORAGE FACILTYY H11 & RFSH & SWM & 1990 & 2010 & 372 & $\mathrm{PC3}$ & 0 & GOOD & MARGMAL \\
\hline FY98 & 11 & $2002 w \mathrm{~L}$ & RMW STORAGE FACLLITY \#12 & RFSH & swM & 1990 & 2010 & 372 & PC3 & 0 & GOOD & MARGINAL \\
\hline FY 98 & 11 & $272 \mathrm{LE}$ & $\begin{array}{l}\text { PATROL HEADQUARTERS - CENTRAL ALARM } \\
\text { FACILTYY }\end{array}$ & DYN & GPF & 1982 & 2017 & 847 & PCI & 20 & MARGINAL. & POOR \\
\hline FY 98 & i1 & 2920GWWETC2 & ENERGY TECHNOLOGY CENTER (ETC2) $23930 \mathrm{GWW}$ & DYN & GPF & 1975 & 2012 & 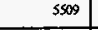 & PCI & 25 & MARGINAL & POOR \\
\hline FY 98 & 11 & 2940GWWETCI & ENERGY TECHNOLOGY CENTER (ETCI) $12940 \mathrm{GWW}$ & DYN & GPF & 1975 & 2012 & 5509 & PC1 & 25 & MARGINAL & POOR \\
\hline FY 98 & 11 & 3763 & OFFICE BUILDING & DYN & GPF & 1971 & 2017 & 673 & $\mathrm{PC1}$ & 38 & MARGINAL & POOR \\
\hline FY 98 & 11 & 436 & TRAINING FACILTY & BWHC & FFTF & 1973 & & 671 & $\mathrm{PCI}$ & so & MARGINAL & VERIFIABLE \\
\hline FX 98 & 11 & 47138 & FFTF MAINTENANCE SHOP & BWHC & FFTF & 1978 & & 3070 & $\mathrm{PCI}$ & $\infty$ & MARGNAL & POOR \\
\hline FY 98 & 11 & MO400 & MOBLLE OFFICE $Q 271 \mathrm{~B}$ & DYN & GPF & 1981 & 2007 & 429 & $\mathrm{PCI}$ & 27 & MARGINAL & POOR \\
\hline FY 98 & 11 & MO414 & MOBLE OFFICE TRAILER (1104N) & DYN & GPF & 1984 & 2012 & 1058 & $\mathrm{PC1}$ & $\mathbf{x}$ & MARGINAL & POOR \\
\hline FY 98 & 10 & $2403 \mathrm{WA}$ & RMW STORAGE FACILITY & $\mathrm{RFSH}$ & SWM & 1992 & 2012 & 3160 & $\mathrm{PC3}$ & 0 & LKEE NEW & MARGNAL \\
\hline FY 98 & 10 & $2403 \mathrm{WB}$ & RMW STORAGE FACIITYY & RFSH & SWM & 1993 & 2013 & 3160 & $\mathrm{PC3}$ & 0 & LKKE NEW & MARGNAL \\
\hline FY 98 & 10 & $2403 \mathrm{WC}$ & RMW STORAGE FACILTYY & RFSH & SWM & 1993 & 2013 & 3160 & $\mathrm{PC3}$ & - & LIKE NEW & MARGNAL \\
\hline
\end{tabular}




\begin{tabular}{|c|c|c|c|c|c|c|c|c|c|c|c|c|}
\hline $\begin{array}{l}\text { EVALU } \\
\text { SCHED }\end{array}$ & $\begin{array}{l}\text { PRIOTTY } \\
\text { SCORE }\end{array}$ & IDENTIFIER & DESCRIPTION & CONTRA & PROJECT & $\begin{array}{l}\text { YEAR } \\
\text { BUILT }\end{array}$ & $\begin{array}{l}\text { YEAR } \\
\text { SURPLUS }\end{array}$ & $\begin{array}{l}\text { AREA SQ } \\
\text { METERS }\end{array}$ & $\begin{array}{c}\text { PERP.C } \\
\mathbf{A T} .\end{array}$ & $\begin{array}{l}\text { TOTAL } \\
\text { OCCUP }\end{array}$ & $\begin{array}{l}\text { FACILITY } \\
\text { CONDTIION } \\
\text { RATING }\end{array}$ & $\begin{array}{l}\text { EXISTING } \\
\text { ANALYSIS } \\
\text { RATING }\end{array}$ \\
\hline FY 98 & 10 & $2603 \mathrm{WD}$ & RMW STORAGE FACILITY & RFSH & sWM & 1993 & 2013 & 5135 & PC3 & 0 & LIKE NEW & MARGINAL \\
\hline FY 98 & 10 & $2004 \mathrm{WA}$ & LONG TERM DRUM STORAGE FACLLTYY & RFSH & SWM & 1996 & 2016 & 2035 & $\mathrm{PC3}$ & 0 & LIKE NEW & MARǴNAL \\
\hline FY 98 & 10 & $2404 \mathrm{WB}$ & LONG TERM DRUM STORAGE FACIIITY & RFSH & SWM & $19 \%$ & 2016 & 20035 & $\mathrm{PC3}$ & 0 & LKE NEW & MARGINAL \\
\hline FY 98 & 10 & $2404 \mathrm{WC}$ & LONG TERM DRUM STORAGE FACILITY & RFSH & SWM & 1996 & 2016 & 2035 & $\mathrm{PC} 3$ & 0 & LIKE NEW & MARGNAL \\
\hline FY 98 & 10 & $233 \mathrm{E}$ & WATER FILTRATION PLANT & DYN & GPF & 1960 & 1998 & 697 & $\mathrm{PC2}$ & 4 & GOOD & POOR \\
\hline FY 98 & 10 & $283 \mathrm{w}$ & WATER FILTRATION PLANT & DYN & GPF & 1960 & 2001 & 770 & $\mathrm{PC} 2_{2}$ & 4 & GOOD & POOR \\
\hline FY 98 & 10 & 315 & FILTER PLANT BUILDING & DYN & $\begin{array}{c}\text { GPF } \\
\end{array}$ & 1962 & 2007 & 765 & $\mathrm{PC2}$ & 2 & GOOD & POOR \\
\hline FY98 & 10 & 403 & FUELS STORAGE FACLLTTY & BWHC & FFTF & 1980 & & 1234 & $\mathrm{PC} 2$ & $s$ & MARGINAL & VERIFIABLE \\
\hline FY 98 & 10 & 4703 & FFTF CONTROL BULLDING & BWHC & FFTF & 1978 & & 1323 & PC2 & 10 & MARGINAL & VERIFIABLE \\
\hline FY 98 & 10 & 4717 & REACTOR SERVICE BUILDING & BWHC & FFTF & 1978 & & 4605 & PC2 & 4 & MARGINAL & VERIFIABLE \\
\hline FY98 & 10 & 491E & ITS SERVICE BUILDING, EAST & BWHC & FFTF & 1978 & & 1531 & PC2 & 2 & MARGINAL & VERIFIABLE \\
\hline FY 98 & 9 & 2258 & WASTE ENCAPSULATION AND STORAGE FACILTY & BWHC & WESF & 1973 & 2017 & 1901 & PC3 & 9 & MARGINAL & ACCEPTABLE \\
\hline FY 98 & 9 & $408 \mathrm{~A}$ & MAIN HEAT DUMP, EAST & BWHC & FFTF & 1978 & & 1821 & PC2 & $\mathbf{0}$ & MARGINAL & VERIFIABLE \\
\hline FY 98 & 9 & $408 \mathrm{~B}$ & MAIN HEAT DUMP, SOUTH & BWIIC & FFrF & 1978 & & $17 \%$ & PC2 & 0 & MARGINAL & VERIFIABLE \\
\hline FY 98 & 9 & $408 \mathrm{C}$ & MAIN HEAT DUMP, WEST & BWHC & FFTF & 1978 & & 1815 & $\mathrm{PC2}$ & 0 & MARGINAL & VERIFIABLE \\
\hline FY 98 & 9 & $4621 \mathrm{~W}$ & AUXILIARY EQUIPMENT BUILDING,WEST & BWtic & FFTF & 1978 & & $\$ 09$ & PC2 & 0 & MARGINAL & VERIFIABLE \\
\hline FY 98 & 9 & 483 & COOLING TOWERS & BWHC & FFTF & 1978 & & 36 & PC2 & 0 & MARGINAL & VERIFIABLE \\
\hline FY 98 & 9 & 4915 & HTS SEERVICE BUILDING, SOUTH & BWHC & FFTF & 1978 & & $n$ & $\begin{array}{l}\text { PC2 } \\
\end{array}$ & 0 & MARGINAL & VERIFIABLE \\
\hline FY 98 & 9 & $491 \mathrm{~W}$ & HTS SERVICE BUILDING, WEST & BWHC & FFTF & 1978 & & 2224 & $\mathrm{PC2}$ & 0 & MARGINAL & VERIFIABLE \\
\hline FY 98 & 8 & $225 \mathrm{BB}$ & K3 FILTER PTT & BWHC & WESF & 1973 & & 73 & $\mathrm{PC2}$ & 0 & MARGINAL & ACCEPTABLIE \\
\hline FY 98 & 8 & 206810 & STACK, WESF & BWHC & WESF & 1973 & & & PC2 & 0 & MARGINAL & ACCEPTABLE \\
\hline FY 98 & 8 & 440 & 90 DAY HAZARDOUS WASTE STORAGE PAD & BWHC & FFTF & 1993 & & 140 & PC2 & 0 & LKE NEW & POOR \\
\hline FY 98 & 7 & 27045 & OFFICE BUILDING & DYN & GPF & 1944 & 2012 & 760 & $\mathrm{PCI}$ & so & GOOD & POOR \\
\hline FY 98 & 7 & $271 \mathrm{E}$ & VEHICLE MAINTENANCE SHOP & DYN & GPF & 1985 & 2017 & 6800 & $\mathrm{PCl}$ & 15 & GOOD & ACCEPTABLE \\
\hline FY 98 & 7 & $275 \mathrm{w}$ & HEAVY EQUIPMENT SHOP & DYN & GPF & 1944 & 2007 & 332 & $\mathrm{PCl}$ & 2 & MARGINAL & POOR \\
\hline FY98 & 7 & $254 \mathrm{E}$ & STEAM PLANT BUILDING & DYN & GPF & 1980 & 2031 & 3141 & $\mathrm{PCI}$ & 34 & GOOD & POOR \\
\hline FY 98 & 7 & 3010 & BENTON CO. SHERIFF HEADQUARTER & DYN & GPF & 1980 & 2017 & 614 & $\mathrm{PCl}$ & 12 & GOOD & POOR \\
\hline FY 98 & 7 & 384 & STEAM POWER HOUSE BUILDING & DYN & GPF & 1943 & 2037 & 1594 & $\mathrm{PCl}$ & 40 & GOOD & POOR \\
\hline FY 98 & .7 & $4713 \mathrm{~A}$ & DRIVERS OPERATIONS FACILTYY & BWHC & FFTF & 1978 & & 517 & $\mathrm{PCI}$ & 8 & MARGINAL & POOR \\
\hline FY 98 & 7 & 47228 & BUILDING & DYN & GPF & 1982 & 2007 & $4 ! 9$ & $\mathrm{PCI}$ & 2 & MARGNAL & POOR \\
\hline FY 98 & 7 & $4222 \mathrm{C}$ & PAINTERS SHOP & DWN & GPF & 1982 & 2007 & 372 & $\mathrm{PCl}$ & 2 & MARGNAL & POOR \\
\hline FY 98 & 7 & 47348 & STTE SERVICE MANTTENANCE & DYN & GPF & 1982 & 2007 & 735 & PC1 & 2 & MARGINAL & POOR \\
\hline FY 98 & 7 & 4862 & $\begin{array}{l}\text { FMEF ENTRY WING OFFICE FMEF OFFICE - ENTRY } \\
\text { WING }\end{array}$ & BWHC & FFF & 1984 & 2037 & 3721 & $\mathrm{PCl}$ & 30 & GOOD & MARGNAL \\
\hline FY 98 & 7 & $662 \mathrm{~A}$ & PATROL EXERCISE \& TRAINING FACILUYY $\otimes$ PTA & DYN & GPF & 1983 & 2017 & 465 & $\mathrm{PCI}$ & 5 & MARGINAL & POOR \\
\hline
\end{tabular}




\begin{tabular}{|c|c|c|c|c|c|c|c|c|c|c|c|c|}
\hline $\begin{array}{l}\text { EVALU } \\
\text { SCHED }\end{array}$ & $\begin{array}{l}\text { PRIOITY } \\
\text { SCORE }\end{array}$ & DENTIFIER & DESCRIPTION & CONTRA & PROJECT & $\begin{array}{l}\text { YEAR } \\
\text { BUILT }\end{array}$ & $\begin{array}{l}\text { YEAR } \\
\text { SURPLUS }\end{array}$ & $\begin{array}{l}\text { AREA SQ" } \\
\text { METERS }\end{array}$ & $\begin{array}{l}\text { PERF. } \\
\text { AT. }\end{array}$ & $\begin{array}{l}\text { TOTAL } \\
\text { OCCUP }\end{array}$ & $\begin{array}{l}\text { FACILITY } \\
\text { CONDITION } \\
\text { RATING }\end{array}$ & $\begin{array}{l}\text { EXISTING } \\
\text { ANALYSIS } \\
\text { RATING }\end{array}$ \\
\hline FY 98 & 7 & MO273 & MOBILE OFFICE PUREX (OUTSIDE FENCE) & DYN & GPF & $19900^{\circ}$ & 2007 & 859 & $\mathrm{PCl}$ & 81 & GOOD & POOR \\
\hline FY 98 & 6 & 6270 & ENVIRONMENTAL DATA REMEDIALTRACKING & RFSH & HAS & 1993 & 2024 & 435 & $\mathrm{PCl}$ & 14 & LIKE NEW & MARGINAL \\
\hline FY 98 & 6 & M0294 & MOBILE OFFICE & DYN & GPF & 1995 & 2012 & 1374 & $\mathrm{PCl}$ & $\$ 0$ & LIKE NEW & POOR \\
\hline FY 98 & $\sigma$ & MO970 & MOBHLE OFFICE & DYN & GPF & 1993 & 2007 & 312 & PCI & 26 & LIKE NEW & POOR \\
\hline FY 98 & 6 & M0971 & MOBILE OFFICE & DYN & GPF & 1993 & 2007 & 312 & $\mathrm{PCI}$ & 26 & LKKE NEW & POOR \\
\hline FY 98 & 0 & 1330N & 100-N WASTE STORAGE FACILITY & PHMC & & & & & $\mathrm{PCy}$ & & & \\
\hline FY 98 & 0 & $17 \pi \mathrm{TD}$ & I $m$ TERMANAL DRIVE, RICHLAND & NUMTC & & & & & $\mathrm{PCY}$ & & & \\
\hline FY 98 & 0 & MO481 & OPERATIONS OFFICE TRAILER (AKA 103(N) & RFSH & & & & 446 & $\mathrm{PCy}$ & & & \\
\hline FY 98 & & 11001ADWIN & $\begin{array}{l}\text { 100 JADWN BLDG (RICHLAND)HEADQUARTERS } \\
\text { OFFICE BULLDING }\end{array}$ & DWN & & & & 4423 & $\mathrm{PCy}$ & & & \\
\hline FY 98 & & 1112 & FUEL STORAGE BUILDING & PHMC & & & & 6 & PCX & & & \\
\hline FY 98 & & $1112 \times \mathrm{A}$ & MICROWAVE TOWER ANNEX & PHMC & & & & 13 & $P C X$ & & & \\
\hline FY 98 & & 11201 & TOOL SHED & PHMC & & & & & $\mathrm{PCX}$ & & & \\
\hline FY 98 & & $1171 \mathrm{~A}$ & BUS WASH FACILTYY & PHMC & & & & 24 & $\mathrm{PCX}$ & & & \\
\hline FY 98 & & $117 \mathrm{C}$ & SPARE PARTS STORAGE SHED & PPMC & & & & 93 & $\mathrm{PCx}$ & & & \\
\hline FY 98 & & 1178 & CHOLORING STORAGE STRUCTURE & PIMC & & & & & $P C x$ & & & \\
\hline FY 98 & & 1180 & PESTICIDE STORAGE BUILDING & PHMC & & & & 6 & $\mathrm{POX}$ & & & \\
\hline FY 98 & & $12001 \mathrm{ADWIN}$ & $\begin{array}{l}\text { TCPC (I200 IADWIN, RICHLANDDTCPC OFFICE } \\
\text { BULLDING }\end{array}$ & DVN & & & & 8616 & PCy & & & \\
\hline FY 98 & & IS1SN & MULTICRAFT SHOP & PHMC & & & & 446 & $\mathrm{PCx}$ & & & \\
\hline FY98 & & $1510 \mathrm{~N}$ & CARPENTER SHOP & PHMC & & & & 45 & $\mathrm{PCX}$ & & & \\
\hline FY $\mathscr{\Re}$ & & ISIN & PAINT SHOP & PHMC & & & & 74 & PCX & & & \\
\hline FY 98 & & ISI8N & FLXED METAL ELECTRICAL SHOP & PHMC & & & & 74 & $P C X$ & & & \\
\hline FY 98 & & $1519 \mathrm{~N}$ & FLKED METAL FITTERS SHOP & PHMC & & & & 74 & $\mathrm{PCX}$ & & & \\
\hline FY 98 & & $151 \mathrm{~B}$ & PRIMARY SUBSTATION & PHMC & & & & 610 & $P O X$ & & & \\
\hline FY 98 & & $151 \mathrm{D}$ & PRIMARY SUBSTATION & PHMC & & & & sso & PCX & & & \\
\hline FY 98 & & $1614 \mathrm{k} 3$ & ENVIRONMENTAL MONTTORING STATION & PHMC & & & & 6 & $\mathrm{PCx}$ & & & \\
\hline FY 98 & & $1701 \mathrm{KA}$ & GUARD OFFICE & PHMC & & & & & PCX & & & \\
\hline FY 98 & & 1717AKE & FAN HOUSE BY 1717 & PHMC & & & & & $\mathrm{PCX}$ & & & \\
\hline FY 98 & & $177 \mathrm{KE}$ & MANTENANCE TRANSPORTATION SHOP & $\begin{array}{l}\text { PHMC } \\
\text { PIM }\end{array}$ & $100 \mathrm{~K}$ & & & & $\mathrm{PC} \times$ & & & \\
\hline FY 98 & & 1 IZAN & $\begin{array}{l}\text { NIIROGEN ELECTRICAL CONTROL BLDG - } \\
\text { PROPOSED }\end{array}$ & PHMC & & & & & PCx & & & \\
\hline FY 98 & & 183.0KW & LIME FEEDER BUILDINGLIME FEEDER BUILDING & PHMC & & & & 86 & $\mathrm{PCx}$ & & & \\
\hline FX 98 & & 1835TD & $\begin{array}{l}\text { VIRRO BLDG (1835 TERMINAL } \\
\text { DR.,RICHLAND)VITRO BUILDING }\end{array}$ & MULT & & & & & $\mathrm{PCy}$ & & & \\
\hline FY 98 & & 183D & $\begin{array}{l}\text { FILTER PLANT POWER OPERATION } \\
\text { FACILITYFLTER FLANT BULDDING }\end{array}$ & PHMC & & & & $\cos 5$ & $\mathrm{PCX}$ & & & \\
\hline
\end{tabular}




\begin{tabular}{|c|c|c|c|c|c|c|c|c|c|c|c|c|}
\hline & & & $x$ & & & & & DHWT & 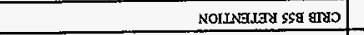 & sร89iz & & $86 \times 1$ \\
\hline & & & $\mathrm{xOd}$ & & & & & OHWT & SaNOd & วรяง।z & & $86 \lambda \mathrm{AI}$ \\
\hline & & & $x \mathrm{xd}$ & & & & & गHW & SanOd & gєяوіح & & $\$ 6 \mathrm{AI}$ \\
\hline & & & $x_{\mathrm{d}}$ & & & & & วHWT & 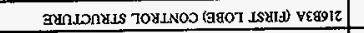 & IVEg9Iz & & 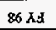 \\
\hline & & & $x_{01}$ & & & & & วHWT & sanOd & vєgوıา & & $86 \mathrm{dA}$ \\
\hline & & & $x$ & & & & & गHКT & 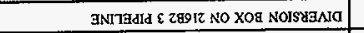 & จะzgตเ & & $86 \mathrm{XI}$ \\
\hline & & & $x$ & & & & wyviv & วнพา & 8Y alxo & 87912 & & $86, x$ \\
\hline & & & $\times \mathrm{Od}$ & & & & & วHWI & 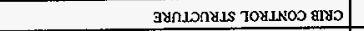 & 80S $\forall 912$ & & $86 \mathrm{AI}$ \\
\hline & & & xod & & & & xaynd & DHWT & کรV ตมว & SpVgle & & $86 \mathrm{AI}$ \\
\hline & & & $x=$ & & & & & วHWI & 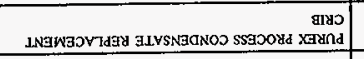 & 008912 & & $86 \mathrm{XI}$ \\
\hline & & & od & & & & & วัพา & z-LEY gIX) & u\&vglz & & $86 \mathrm{NI}$ \\
\hline & & & 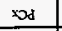 & & & & & วHWT & xoa No1sะana & zosverz & & $86 \mathrm{AJ}$ \\
\hline & & & $x_{\mathrm{Od}}$ & & & & & วHพา & XO\& NoISXENA & locvoiz & & $86 \times 1$ \\
\hline & & & $x_{\mathrm{Od}}$ & & & & xaynd & SHWT & 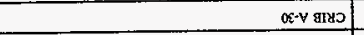 & ocvir & & $86 \times 3$ \\
\hline & & & $x>d$ & 6 & & & & गHWา & 3SกOH TOУ & ILZV91E & & $86 \mathrm{AJ}$ \\
\hline & & & $\infty \mathrm{d}$ & 6 & & & & วнผ1 & 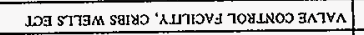 & vgiz & & $\$ \sigma \mathrm{AJ}$ \\
\hline & & & $x_{0 d}$ & & & & XIJUh & DWHd & 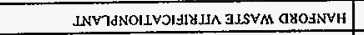 & $a b+2$ & & $85 \lambda y$ \\
\hline & & & $x_{0}$ & & & & & ОнКт & XNVL HOLYO & ixumeiz & & $86 \mathrm{dt}$ \\
\hline & & & $x \mathrm{~d}$ & $\infty$ & & & & วHWX & 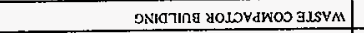 & MEIZ & & $36 \mathrm{AJ}$ \\
\hline & & & $x_{\mathrm{d}}$ & 6 & & & & SNHd & 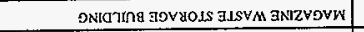 & 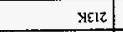 & & $86 \mathrm{At}$ \\
\hline & & & $\infty_{d}$ & $\iota 9$ & & & & วWHd & 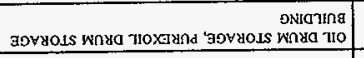 & vore & & $86 \mathrm{AS}$ \\
\hline & & & $x_{d}$ & & & & $s \pi z$ & swHd & asnoH3yVM NOLLORYLLNNOJ dAMU/JLMW & NIIOIZ & & $86 \lambda 1$ \\
\hline . & & & $x \mathrm{dd}$ & & & & & วHWI & aVd TOVYOIS XVG of & $\mathrm{vacoz}$ & & $86 \mathrm{At}$ \\
\hline & & & $x_{d}$ & $2 p L$ & & & & SHWา & - SNOIIVYGdO GLSYM TVLNGWNOZIANa & 3608 & & $868 \mathrm{~s}$ \\
\hline & & & $x_{\mathrm{d}}$ & 8 & & & & DHКT & 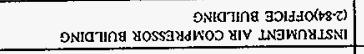 & 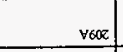 & & $86 \mathrm{AI}$ \\
\hline & & & $x_{d}$ & & & & LNYาd $I$ & OHW7 & NISYG NOLLNGIAI QGLVM & $\triangle L O E$ & & $86 \mathrm{XI}$ \\
\hline & & & $x_{01}$ & $8 \pi$ & & & & วH以า & 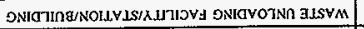 & 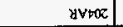 & & $86 \mathrm{AJ}$ \\
\hline & & & $\mathrm{xd}$ & $9 \varepsilon$ & & & & כWHd & 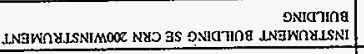 & MLOC & & $86 \times \mathrm{Ju}$ \\
\hline & & & sod & & & & & NXa & 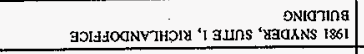 & YEOXNST861 & & $86 \mathrm{As}$ \\
\hline & & & $x_{d}$ & $\mathfrak{E R L}$ & & & & गWHब & 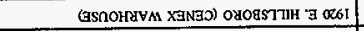 & OdgS7IF०z6t & & $86 \mathrm{XI}$ \\
\hline & & & $\mathrm{x} 0 \mathrm{~d}$ & $\mid t L 1$ & & & & PWHA & 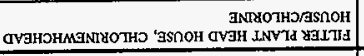 & उस्8ः & & $86 \mathrm{As}$ \\
\hline $\begin{array}{l}\text { ONILVA } \\
\text { SISXTVNV } \\
\text { ONIXSIXI }\end{array}$ & 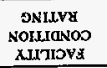 & $\begin{array}{l}\text { dกDSo } \\
\text { TVLOL }\end{array}$ & 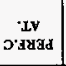 & $\begin{array}{l}\text { SAgISW } \\
\text { hOS Vay }\end{array}$ & $\begin{array}{l}\text { sn'udans } \\
\text { yVax }\end{array}$ & $\begin{array}{l}\text { LTing } \\
\text { yvax }\end{array}$ & vDarodd & VYINOS & Notddryosaa & ygLi.jNaส & $\begin{array}{l}\text { geroos } \\
\text { dJIOIXd }\end{array}$ & $\begin{array}{l}\text { äHos } \\
\text { nTVA }\end{array}$ \\
\hline
\end{tabular}




\begin{tabular}{|c|c|c|c|c|c|c|c|c|c|c|c|c|}
\hline & & & $x_{0 A d}$ & II & & & & DWHid & IZTOSS JIN TYINO TVOOT & VMSZZ & & $86 \times d$ \\
\hline & & & $x_{d}$ & II & & & & DNHג & ElOSS INA TOYINNOS TVDOT & oaszz & & $86 \mathrm{AJ}$ \\
\hline & & & $x$ & & & & & DWHA & 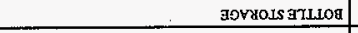 & agta & & $86 \mathrm{AM}$ \\
\hline & & & $x_{0 \rightarrow}$ & $+\infty E$ & & & & JWHd & dOHS S.ðGYXYOMNOYI & a $a+2 a$ & & $86 \mathrm{XI}$ \\
\hline & & & $x_{0 d}$ & $p L$ & & & & כwHd & 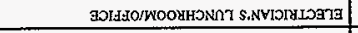 & astac & & $86 \mathrm{AJ}$ \\
\hline & & & $\mathrm{xod}$ & ડєE & & & & OWHd & dOHS NOLLYIHAYA LUYYO IJ7กN & $a+n z$ & & $86 \times I$ \\
\hline & & & $x \mathrm{di}$ & & & & & כWHd & dOHS גalNGddVO & $a z+z a$ & & $86 \lambda \mathrm{AI}$ \\
\hline & & & $x_{0 d}$ & & & & & SWHd & 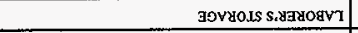 & girza & & $86 \mathrm{dd}$ \\
\hline & & & $x_{\mathrm{d}}$ & 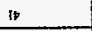 & & & $s-z \pi$ & SWHd & 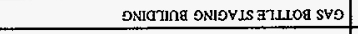 & $\csc \alpha$ & & $868 d$ \\
\hline & & & $x_{d}$ & 08 & & & & SWHd & dOHS YGUUIGATI HAY & $\forall i z z$ & & $86 \mathrm{dI}$ \\
\hline & & & $x \mathrm{Od}$ & 8 & & & & วнพา & 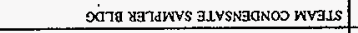 & vozz & & $85 x=$ \\
\hline & & & $x_{0 d}$ & $u$ & & & & OWHd & - GSחOH IOI NOILONULSNOO & aloes & & 86 $\lambda 1$ \\
\hline & & & $x_{\mathrm{d}}$ & 9 & & & & SWHd & 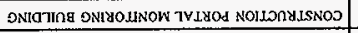 & $8002 \pi$ & & $86 \mathrm{A.j}$ \\
\hline & & $\therefore$ & $x_{\mathrm{d}}$ & & & & & DWHd & 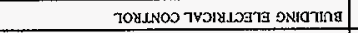 & $\forall Z s \tau-S M 812$ & & $86 \lambda t$ \\
\hline & & & $x$ & & & & & SWES & 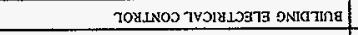 & $z 5 \tau-S \mathrm{M} 81 \mathrm{Z}$ & & $80 \mathrm{AH}$ \\
\hline & & & $x_{\mathrm{d}}$ & & & & & วHพา & 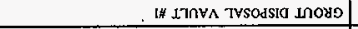 & 101913812 & & $\$ \lambda i s$ \\
\hline & & & $x_{d}$ & $z$ & & & LNVาd-8 & כWHd & 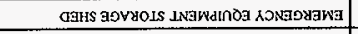 & g8ı & & $86 \lambda \mathrm{As}$ \\
\hline & & & $\mathrm{xos}$ & & & & & จHผT & 1ZZ ANOA SNISVI & เzZ9k & & $86 \mathrm{Xi}$ \\
\hline & & & $x_{0}$ & & & & & วHพา & OCZ घI\%ว & 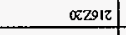 & & $86 \lambda d$ \\
\hline & & & $\times \mathrm{dd}$ & & & & & भHWT & gเฉว 1 Nanกา:t3 & Jingiz & & $86 \mathrm{AI}$ \\
\hline & & & $x_{\mathrm{Dd}}$ & & & & عon & OHWT & 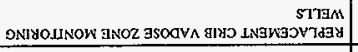 & $\operatorname{tin} 912$ & & $86 \lambda I$ \\
\hline . & & & $x_{0 y}$ & & & & & SHWT & gเมว & 9ingiz & & $80 x 4$ \\
\hline & & & $\times x_{d}$ & & & \multicolumn{2}{|c|}{ wrystn/ton } & วHพา & YNVI HOIVכ/ Iก Hวu & $\operatorname{minsiz}$ & & $86 \mathrm{Ad}$ \\
\hline & & & $\times \mathrm{d}$ & & & & & OHWT & HSกTHYXNVI & $102 \times 1.912$ & & $86 \mathrm{Ad}$ \\
\hline & & & $x$ & & & & & PHWI & ноша & $2 * 1912$ & $\cdot$ & $86 \mathrm{XI}$ \\
\hline & & & $x_{d}$ & & & & & วнพา & 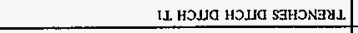 & 1.1912 & & $86 \times 3$ \\
\hline & & & $x_{-d}$ & & & & Wy $\forall A-5$ & วнКт & gzs aldo & $9 z S 9 \mathrm{lz}$ & & $86 \mathrm{AI}$ \\
\hline & & & $x_{0 d}$ & & & & wyvits & OHWT & - szs gเ80 & szs9iz & & $86 \mathrm{AJ}$ \\
\hline & & & $x$ & & & & & SHWT & 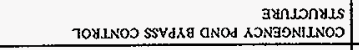 & gezagtz & & $86 \mathrm{AJ}$ \\
\hline & & & $x_{d}$ & & & & & ОHКт & 3XกLORY USTOYLNOS GNOA XONGONILNOO & v8zag iz & & $86 \mathrm{AJ}$ \\
\hline & & & $x_{01}$ & & & & & DHWT & 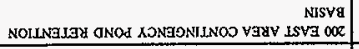 & $0 \varepsilon+\infty T^{2} z$ & & $86 \lambda \mathrm{A}$ \\
\hline & & & $\mathrm{xd}$ & & & & & DHWI & \$99 HOHO NOILN3JaУ & 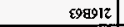 & & $86 \mathrm{Ad}$ \\
\hline & & & xad & & $\cdot$ & & & DHWT & NOILNG.J39 Z98 घाष्) & z९৪9IZ & & $86 \mathrm{XI}$ \\
\hline $\begin{array}{l}\text { ONIJVY } \\
\text { SISATVNY } \\
\text { ONIJSIXI }\end{array}$ & $\begin{array}{c}\text { ONILYY } \\
\text { NoIJIaNOS } \\
\text { RuTIOVI } \\
\end{array}$ & $\begin{array}{l}\text { dnOPOO } \\
\text { TVIOL }\end{array}$ & $\begin{array}{c}\text { :LY } \\
\text { O'dYAad }\end{array}$ & $\begin{array}{l}\text { sqa.ıม } \\
\text { fos vayv }\end{array}$ & $\begin{array}{l}\text { SnTdxns } \\
\text { yvax }\end{array}$ & $\begin{array}{l}\text { Limg } \\
\text { dvax }\end{array}$ & Lิaroyd & YYXNOD & Noludidosad & YaLaungaI & $\begin{array}{l}\text { aroos } \\
\text { x.IIOIHa }\end{array}$ & $\begin{array}{l}\text { garos } \\
\text { MTVAT }\end{array}$ \\
\hline
\end{tabular}




\begin{tabular}{|c|c|c|c|c|c|c|c|c|c|c|c|c|}
\hline $\begin{array}{l}\text { EVALU } \\
\text { SCHED }\end{array}$ & $\begin{array}{l}\text { PRTOITY } \\
\text { SCORE }\end{array}$ & IDENTIFTER & DESCRIPTION & CONTRA & PROJECT & $\begin{array}{l}\text { YEAR } \\
\text { BUILT }\end{array}$ & $\begin{array}{c}\text { YEAR } \\
\text { sURPLUS }\end{array}$ & $\begin{array}{l}\text { AREA SQ } \\
\text { METERS }\end{array}$ & $\begin{array}{c}\text { PERF.C } \\
\text { AT. }\end{array}$ & $\begin{array}{l}\text { TOTAL } \\
\text { OCCUP }\end{array}$ & $\begin{array}{l}\text { FACILITY } \\
\text { CONOTIION } \\
\text { RATING }\end{array}$ & $\begin{array}{l}\text { EXISTING } \\
\text { ANALYSIS } \\
\text { RATING }\end{array}$ \\
\hline FY 98 & & $2309 \mathrm{w}$ & SHEETMETAL SHOP & DYN & & & & 372 & PCy & & & \\
\hline FY 98 & & $2310 \mathrm{~W}$ & MATERIAL STORAGE & PHMC & & & & 279 & $\mathrm{PCX}$ & & & \\
\hline FY 93 & & $2318 \mathrm{~W}$ & PAINTER SHOP & PHMC & & & & & $\overline{P C x}$ & & & \\
\hline FY 98 & & $231 \mathrm{W1} 51$ & VAULT & LMHC & & & & & $\mathrm{PCX}$ & & & \\
\hline FY 98 & & 2400 E GROUT & DRY MATERIAL FACILTY CONTROL ROOM & LMHC & & & & & $\mathrm{PCX}$ & & & \\
\hline FY 98 & & 2A02EA GROUT & DRY MATERIAL FACILTTY UNLOADING FACILTYY & LMHC & & & & & $\frac{\mathrm{PCX}}{2}$ & & & \\
\hline FY 98 & & 2402EB GROUT & DRY MATERIAL FACILTTY CEMENT SILO & LMHC & & & & & $\overline{\mathrm{PCX}}$ & & & \\
\hline$\overline{F Y 98}$ & & 2402EC GROUT & DRY MATERIAL FACILTYY FLY ASH SILO & LMHC & & & & & PCX & & & \\
\hline FY 98 & & 2402ED GROUT & DRY MATLRIAL FACILTYY POTTERY CLAY SILO & LMIIC & & & & & $\mathbf{P C x}$ & & & \\
\hline FY 9 & & 2402EF GROUT & DRY MATERIAL FACLILTYY ATTAPULGTEE CLAY & LMHC & & & & & $\mathrm{PCX}$ & & & \\
\hline FY 98 & & 2402 EG GROUT & DRY MATERIAL FACILITY TRANSFER PUMP PT & LMHC & & & & & PC: & & & \\
\hline FY 98 & & $2402 \mathrm{WA}$ & MIXED WASTE STOREAGE & PHMC & & & & & $\mathrm{PCX}$ & & & \\
\hline FY 98 & & $2403 \mathrm{E}$ & $\begin{array}{l}\text { DMRHF DRY BLENDED STORAGETRUCK } \\
\text { LOADOUT FACILTYY }\end{array}$ & LMHC & & & & 19 & $\mathrm{PCX}$ & & & \\
\hline FY 9 & & 2403EA & COMPRESSOR LEAN-TO & LMHC & & & & 24 & $\mathrm{PCX}$ & & & \\
\hline FY 98 & & $2404 \mathrm{E}$ & COMPRESSOR/RAIL RECEIVING & LMKC & & & & 21 & $P C x$ & & & \\
\hline FY 98 & & 240 SIS1 & DNVERSION BOX & LMHC & S.FARM & & & & PCX & & & \\
\hline FY 98 & & 2405152 & DIVERSION BOX & LMHC & S-FARM & & & & $p+x$ & & & \\
\hline FY 98 & & $2405302 \mathrm{C}$ & ACID STORAGE TANK & LMHC & & & & & $\mathrm{PCX}$ & & & \\
\hline FY 98 & & $241 \mathrm{~A}$ & $\begin{array}{l}\text { WASTE DISPOSAL TANK FARM, } 6 \text { TANKSI MILLON } \\
\text { GALEATANK FARMS } 6 \text { TANKS, } 2 \\
\text { DIVERSONONBOXESTTANK FARM }\end{array}$ & LMHC & TKF & & & & $\mathrm{PCx}$ & & & \\
\hline FY 98 & & $241 \mathrm{AOIB}$ & Central Phenp Pits, sluves Pit & LMHC & A-Farm & & & & $\mathrm{PC} x$ & & & \\
\hline FY 98 & & 2A1AOIC & Sluice Pil & LMHC & A-Farm & & & & $\mathrm{PCX}$ & & & \\
\hline FY 98 & & 241 AOID & Sluioe Pit & LMHC & A-Form & & & & $\mathrm{PCX}$ & & & \\
\hline FY 98 & & 2A1AOIE & Sluico Pit & LMHC & A-Farm & & & & $\mathrm{PCX}$ & & & \\
\hline FY 98 & & 2AIAOLH & Distributor Pit & LMHC & A-Frarm & & & & $\overline{P C X}$ & & & \\
\hline FY 98 & & $241 \mathrm{AO} 2 \mathrm{~B}$ & Sluice Pit. & LMHC & A-Famm & & & & $\mathrm{PCX}$ & & & \\
\hline FY 98 & & $2 A 1 A O 2 C$ & Sluioe Pit & LMHC & A-Farm & & & & PCx & & & \\
\hline FY 98 & & 241A02D & Sluice PiI & LMHC & A-Frarm & & & & $\mathrm{PCx}$ & & & \\
\hline FY 98 & & $241 \mathrm{~A} 02 \mathrm{E}$ & Sluice Pit & LMHC & A.Farm & & & & $\mathrm{PCx}$ & & & \\
\hline FY 98 & & 2411443 & DIVERSION BOXES & LMHC & & & & & $\overline{P C X}$ & & & \\
\hline FY 98 & & $241 \mathrm{~A} 144$ & DIVERSION BOXES & LMHC & & & & & $\mathrm{PCX}$ & & & \\
\hline FY 98 & & $241 \mathrm{~A} 145$ & DIVERSION BOXES & LMHC & & & & & $\mathrm{PCx}$ & & & \\
\hline FY 98 & & $241 \mathrm{~A} 146$ & DINERSION BOXES & LMHC & & & & & $\mathrm{PCX}$ & & & \\
\hline FY 98 & & $241 \mathrm{~A} 147$ & DIVERSION BOXES & LMHC & & & & & $\mathrm{PCX}$ & & & \\
\hline
\end{tabular}




\begin{tabular}{|c|c|c|c|c|c|c|c|c|c|c|c|c|}
\hline $\begin{array}{l}\text { EVALE } \\
\text { SCHED }\end{array}$ & $\begin{array}{l}\text { PRIOTTY } \\
\text { SCORE }\end{array}$ & IDENTIFIER & DESCRIPTION & CONTRA & PROJECT & $\begin{array}{l}\text { YEAR } \\
\text { BUILT }\end{array}$ & $\begin{array}{l}\text { YEAR } \\
\text { SURPLUS }\end{array}$ & $\begin{array}{l}\text { AREA SOF } \\
\text { METERS }\end{array}$ & $\begin{array}{l}\text { PERF.C } \\
\text { AT. }\end{array}$ & $\begin{array}{l}\text { TOTAL } \\
\text { OCCUP }\end{array}$ & $\begin{array}{c}\text { FACILITY } \\
\text { CONDFTKON } \\
\text { RATING }\end{array}$ & $\begin{array}{l}\text { EXISTING } \\
\text { ANALYSII } \\
\text { RATING }\end{array}$ \\
\hline FY 9 & & $241 \mathrm{~A} 148$ & DVVERSION BOXES & LMHC & & & & & $\mathrm{PCX}$ & & & \\
\hline FY 98 & & 2411149 & DIVERSION BOXES & LMHC & & & & & PCX & & & \\
\hline FY 98 & & $241 \mathrm{~A} 150$ & DNERSION BOXES & LMHC & & & & & PCX & & & \\
\hline FY 98 & & $241 \mathrm{ALST}$ & DNVERSION BOXES & LMHC & A-Fam & & & & $\mathbf{P C x}$ & & & \\
\hline FY 98 & & $241 \mathrm{~A} 152$ & DNERSION BOX & LMHC & A. Farm & & & & PCx & & & \\
\hline FY 98 & & $241 \mathrm{~A} 153$ & DNERSION BOX & LMHC & A-Farm & & & & $\mathrm{PCx}$ & & & \\
\hline FY 98 & & $241 \mathrm{~A} 201$ & $\begin{array}{l}\text { EMERGENCY COOLING WATERSTORAGE TANKS SE } \\
\text { OF PUREX }\end{array}$ & LMHC & PUREX & & & & $\mathrm{PCx}$ & & & \\
\hline FY 98 & & $241 \mathrm{~A} 271$ & TANK FARM CONTROL HOUSE & LMHC & TKF & & & 51 & PCX & & & \\
\hline FY 98 & & $241 \mathrm{~A} 271 \mathrm{~A}$ & INSTRUMENT BUILDING & LMAL & & & & 459 & $\mathrm{PCx}$ & & & \\
\hline FY 98 & & $241 \mathrm{A302 \textrm {A }}$ & CATCH TANK & EMITC & AfFam & & & & $\mathrm{PCX}$ & & & \\
\hline FY 98 & & $241 \mathrm{~A} 350$ & DRAINAGE LIFT STATIONCATCH TANK & LMHC & A.Fam & & & & $P C X$ & & & \\
\hline FY 98 & & $241 \mathrm{~A} 401$ & TANK FARM CONDENSER HOUSE & L.MHC & A-F $F_{2 m m}$ & & & 184 & PCX & & & \\
\hline FY 98 & & 241 iA477 & $\begin{array}{l}\text { CONDENSATA RECEIVER AND PUMP PrTCATCH } \\
\text { TANK }\end{array}$ & LMHC & A.Frm & & & & $\mathrm{PCX}$ & & & \\
\hline FY 98 & & 241 IASOI & CONDENSATE VALVE PIT & LMHC & & & & & $\mathrm{PCX}$ & & & \\
\hline$F Y 98$ & & $241 \mathrm{AZOS}$ & TANK FARM COMPRESSOR HOUSE & LMHC & TKF & & & 85 & $\mathrm{PCX}$ & & & \\
\hline FY $\mathscr{B}$ & & $241 \wedge 702$ & TANK FARM FAN HOUSE & LMIIC & TKF & & & 89 & $\mathrm{PCX}$ & & & \\
\hline FY 98 & & $241 \mathrm{AA}$ & VALVE PTT & LMHC & A.Farm & & & & $P C X$ & & & \\
\hline FY 98 & & $241 \mathrm{AB}$ & VALVE PT & LMHC & A.Fam & & & & $\mathrm{PCX}$ & & & \\
\hline FY 98 & & 24 IACT 400 & EMERGENCY COOLING TOWER & LMHC & A-FARM & & & & $\mathrm{PCX}$ & & & \\
\hline FY 98 & & $241 \mathrm{AN}$ & TANK FARM (7 TANKS)AN-TANK FARM & LMHC & & & & & $P C x$ & & & \\
\hline FY 98 & & 2AIANOIC & LEAK DETECTION PIT & LMHC & AN-FARM & & & & $P C X$ & & & \\
\hline FY 98 & & 241ANOID & RECEIVER PIT & LMHC & AN-FARM & & & & $P C_{x}$ & & & \\
\hline FY 98 & & $241 \mathrm{AN} 02 \mathrm{C}$ & LEAK DETECTION PIT & LMHC & AN.FARM & & & & $\mathrm{PCX}$ & & & \\
\hline FY 98 & & $241 \mathrm{ANO3C}$ & LEAK DETECTION PTT & LMHC & AN-FARM & & & & $P C x$ & & & \\
\hline FY 98 & & 2AIANO4C & LEAK DETECTION PIT & LMHC & AN-FARM & & & & FCX & & & \\
\hline FY 98 & & $241 \mathrm{ANOSC}$ & LEAK DETECTION PIT & LMHC & AN-FARM & & & & POX & & & \\
\hline FY 98 & & 241ANOSC & LEAK DETECTION PRT & LMHC & AN-FARM & & & & $\mathrm{PCX}$ & & & \\
\hline FY 98 & & 241ANOOC & LEAK DETECTION PTT & LMHC & AN-FARM & & & & $\mathrm{PCX}$ & & & \\
\hline FY98 & & 241 AN271 & NSTRUMENT CONTROL HOUSE & LMHC & & & & 13 & $P C X$ & & & \\
\hline FY 98 & & $241 \mathrm{AN} 273$ & COMPRESSOR BULDING & LMHC & & & & 24 & $P C x$ & & & \\
\hline FY 98 & & $241 \mathrm{AN} 274$ & CAUSTIC ADDITION CONTROL ROOM MIXER PUMP & LMHC & & & & & $\mathrm{FC} \times$ & & & \\
\hline FY 98 & & 2A1ANA & VALVE PTT & LMHC & & & & & $\mathrm{PCX}$ & & & \\
\hline FY 98 & & 241 ANB & VALVE PIT & LMHC & & & & & $\mathrm{PCx}$ & & & \\
\hline
\end{tabular}




\begin{tabular}{|c|c|c|c|c|c|c|c|c|c|c|c|c|}
\hline $\begin{array}{l}\text { EVALU } \\
\text { SCHED }\end{array}$ & $\begin{array}{l}\text { PRIORTY } \\
\text { SCORE }\end{array}$ & IDENTIFTER & DESCRIPTION & CONTRA & PROJECT & $\begin{array}{l}\text { YEAR } \\
\text { BUNLT }\end{array}$ & $\begin{array}{l}\text { YEAR } \\
\text { SURPLUS }\end{array}$ & $\begin{array}{l}\text { ARBA SQH } \\
\text { METERS }\end{array}$ & $\begin{array}{l}\text { PERr.c } \\
\text { AT. }\end{array}$ & $\begin{array}{l}\text { TOTAL } \\
\text { OCCUP }\end{array}$ & $\begin{array}{l}\text { FACIITTY } \\
\text { CONDITION } \\
\text { RATING }\end{array}$ & $\begin{array}{l}\text { EXISTING } \\
\text { ANALYSIS } \\
\text { RATING }\end{array}$ \\
\hline FY 98 & & $241 \mathrm{AP}$ & $\begin{array}{l}\text { WASTE STORAGE TANK FARMTANK FARM (8) } \\
\text { TANKS)AP TANK FARM }\end{array}$ & LMHC & & & & & $\overline{P C x}$ & & & \\
\hline FY 98 & & $241 \mathrm{APO} D \mathrm{D}$ & WASTE PUMP PTT AND TRANSFERPIPNG & LMHC & & & & & $\mathrm{PCX}$ & & & \\
\hline FY 98 & & $241 \mathrm{AP2O}$ & AP FARM SAMPLES BUILDING & DYN & & & & & POY & & & \\
\hline FY 98 & & $241 \mathrm{AP271}$ & TANK FARM INSTRUMENT BUILDING & LMHC & & & & 25 & $\mathrm{PCX}$ & & & \\
\hline FY 98 & & $241 \mathrm{AP} 273$ & COMPRESSOR BULLDING & LMHC & & & & 207 & $\mathrm{PCX}$ & & & \\
\hline FY 98 & & 24 IAPSOI & WATER SERYICE BUILDING & LMHC & & & & 13 & $\mathrm{PCX}$ & & & \\
\hline FY 98 & & 241AP90I & $\begin{array}{l}\text { VENTILATTON PTTS WTH INSTRUMENT } \\
\text { ENCLOSURE }\end{array}$ & $\overline{\text { PHMC }}$ & & & & & $\overline{P C x}$ & & & \\
\hline FY 98 & & $241 \mathrm{AP} 902$ & $\begin{array}{l}\text { VENTILATION PTSS WTHH INSTRUMENT } \\
\text { ENCLOSURE }\end{array}$ & PHMC & & & & & $\mathrm{PCX}$ & & . & \\
\hline FY 98 & & $24 \backslash A P 903$ & $\begin{array}{l}\text { VENTLAATION PIS WIIH INSTRUMENT } \\
\text { ENCLOSUREE }\end{array}$ & 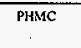 & & & & & $\mathrm{PCX}$ & & & \\
\hline FY 98 & & $241 \mathrm{AP} 904$ & $\begin{array}{l}\text { VENTLAATON PTrS WMH INSTRUMENT } \\
\text { ENCLOSURE }\end{array}$ & PHMC & & & & & $\mathrm{PCX}$ & & & \\
\hline FY 98 & , & $241 \mathrm{APQP}$ & VALVE PTT & LMHC & & & & & $\mathrm{PCX}$ & & & \\
\hline FY 98 & & 241 ARTSI & DNERSION BOX & LMHC & & & & & $\mathrm{PCX}$ & & & \\
\hline $\begin{array}{lll}\text { FY } 98 \\
\end{array}$ & & 24IARIS2 & DNERSION BOX NO. 2, WASTE TRANSFER LINE & ZMHC & & & & & $\overline{P C X}$ & & & \\
\hline FY 98 & & 241AR\&O1 & $\begin{array}{l}\text { EEECTRICAL AND INSTRUMENTATION BUILDING } \\
\text { NO. } 2\end{array}$ & IMHC & . & & & & $\overline{\mathrm{PCX}}$ & & & \\
\hline FY 98 & & $241 \mathrm{AW}$ & TANK FARM 16 TANKSYAW-TANK FARM & IMHC & PUREX & & & & $\mathrm{PCX}$ & & & \\
\hline FY 98 & & $241 \mathrm{AW} 271$ & AW TANK FARM & LMHC & & & & 29 & $\mathrm{PCX}$ & & & \\
\hline $\mathrm{FY} 98$ & & 241 AW273 & COMPRESSOR BUILDING & LMHC & & & & 24 & $\mathrm{PCX}$ & & & \\
\hline FY 98 & & 241AW201 & WATER SERVICE BUILDING & LMHC & & & & & $\mathrm{PCX}$ & & & \\
\hline FY 98 & & $241 \mathrm{AW}_{\mathrm{A}}$ & VALVE PIT & LMHC & AW-FARM & & & & $\mathrm{PCX}$ & & & \\
\hline FY 98 & & 241AWB & VALVEPTT & LMHC & AW-FARM & & & & PCX & & & \\
\hline FY 98 & & $241, A X$ & $\begin{array}{l}\text { WASTE DISPOSAL TANK FARM, } 4 \text { TANKSI MILLION } \\
\text { GAL EATANK FARM (4 TANKS, I } \\
\text { DIVERSONBOX)AX TANK FARM }\end{array}$ & LMHC & AX-Farm & & & & $\mathrm{PCX}$ & & & \\
\hline FY 98 & & $241 \mathrm{AXO1A}$ & Central Plump Pits, sluioe Pists & LMHC & AX-Farm & & & & PCx & & & \\
\hline FY 98 & & $241 \mathrm{~A} \times 01 \mathrm{~B}$ & Central Purmp Pits, Sluioe Pits & LMHC & AX.Fam & & & & $\mathrm{PCX}$ & & & \\
\hline FY 98 & & $241 \mathrm{AX} \times 1 \mathrm{C}$ & Central Pump Pists, Sluime Pits & LMHC & AX-Fam & & & & $P C x$ & & & \\
\hline FY 98 & & $241 \mathrm{AXO1D}$ & Central Purmo Pits, Sluice Pits & LMHC & AX-Farm & & & & $P C x$ & & & \\
\hline FY 98 & & $241 \mathrm{AXO1F}$ & ANNULUS PUMP PITS & LMHC & & & & & $\mathrm{PCx}$ & & & \\
\hline FY 98 & & $241 \mathrm{AX} 01 \mathrm{VP}$ & Valve Pits & LMHC & AX.Fam & & & & PCX & & & \\
\hline FY 98 & & $241 \mathrm{~A} \times 028$ & Sthios Pit & LMHC & AX.Fum & & & & $\mathrm{PCX}$ & & & \\
\hline FY 98 & & $241 \mathrm{AXO2C}$ & Sturiox Pit & LMHC & AX.Farm & & & & $\mathrm{PCX}$ & & & \\
\hline FY 98 & & $241 \mathrm{AX} \times 2 \mathrm{D}$ & Sluioo Pit & LMHC & AX.Farm & & & & $P C x$ & & & \\
\hline
\end{tabular}




\begin{tabular}{|c|c|c|c|c|c|c|c|c|c|c|c|c|}
\hline & & & $x_{d d}$ & & & & LXYYA $\times \mathbf{S Y}$ & ОНКТ & Ld dWnd SnTSNNG & szoxvirz & & $86 \mathrm{XI}$ \\
\hline & & & $x_{\mathrm{Od}}$ & & & & WAVA $X V$ & วнкт & Hd Goin's & 3ZOXYIDZ & & $86 \mathrm{AI}$ \\
\hline & & & $x_{0 i}$ & & & & WXYS $\mathrm{XV}$ & SHWT & Hd aכการ & बroxvin & & $86 \mathrm{AI}$ \\
\hline & & & $x$ & & & & WaYd:AY & OHWT & II GOIn's & szoxvinz & & $86 \times I$ \\
\hline & & & $x$ & & & & WAYA- $\lambda V$ & ОHWT & แd GอIการ & gzoxVIDz & & $86 \mathrm{AI}$ \\
\hline & & & $x_{0 \mathrm{~d}}$ & & & & wrvatex & วHพา & Hd dWกd SnTnNNV & Aloxvitz & & $86 \lambda+$ \\
\hline & & & $x_{2 \mathrm{~d}}$ & & & & Wdyd- $\lambda v$ & วнพา & IId axin's & $\exists 10 x \vee \div \approx$ & & $86 \mathrm{AI}$ \\
\hline & & & $x \mathrm{~d}$ & & & & WसYA $X V$ & วHพX & IId בכוการ & aloxvitz & & $86 \mathrm{XI}$ \\
\hline & & & $x \mathrm{~d}$ & & & & Wyצd- $\lambda v$ & OHWT & 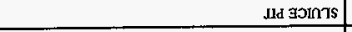 & Dlosvitz & & $80 \mathrm{AJ}$ \\
\hline & & & $\infty$ & & & & WYVA-SV & ОНКา & Hd axn & glos:ibz & & $86 \mathrm{AI}$ \\
\hline & & & $x_{0 d}$ & & & & xaynd & วHพT & 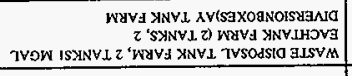 & AVIHZ & & $86 \mathrm{AS}$ \\
\hline & & & $x_{0 \mathrm{~d}}$ & & & & & วнพา & 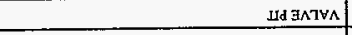 & ISd $8 x v i t z$ & & $86 \mathrm{AI}$ \\
\hline & & & $x_{0 d}$ & & & & & כHWT & MA GกTYA & Ud $\forall \times Y L z$ & & $86 \mathrm{AI}$ \\
\hline & & & $x_{\mathrm{Od}}$ & $L$ & & & & วнพา & 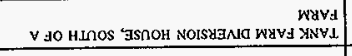 & $2003 x \times 106$ & & $86 \mathrm{Al}$ \\
\hline & & & xod & $\iota z$ & & & unes $x \mathrm{xV}$ & SHWT & 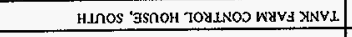 & a10sXYitz & & $\$ 6 \mathrm{AA}$ \\
\hline & & & xod & $\iota z$ & & & wes $: x v$ & OHWT & HLYON 'aSAOH 7OYLNOS WaYA XNVL & VIosxvin & & $86 \mathrm{XI}$ \\
\hline & & & $x_{\mathrm{Od}}$ & & & & & วHผา & 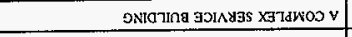 & osXVIte & & $86 \mathrm{AI}$ \\
\hline & & & $x$ & +15 & & & & วHWT & Jd JกTY ILYSNGANOO & $105 \times V I t 2$ & & $36 \mathrm{xJ}$ \\
\hline & & & $x_{\mathrm{Od}}$ & & & & & วHพา & Ld XedPGNa & $100 x V i+2$ & & $80 \mathrm{AI}$ \\
\hline & & & $\infty_{d}$ & & & & & วHผร & XOg norsyana & ssixvitz & & $86 \mathrm{AJ}$ \\
\hline & & & $x_{0 d}$ & & & & $\operatorname{cure}_{\mathrm{d}}-\mathrm{XV}$ & วHพכ & Saxoa nojsyana & $\varepsilon s I X Y \mid+\tau$ & & $85 \lambda d$ \\
\hline & & & $x_{0 \mathrm{~d}}$ & & & & & SHพา & 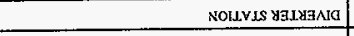 & $i s \mid x v 1+z$ & & $86 \mathrm{AJ}$ \\
\hline & & & $x_{0 d}$ & & & & une $\mathrm{H} \cdot \mathrm{XV}$ & DHพT & SNOILYIS צ9IYAAIO & $151 \times 1 \times 12$ & & $86 \mathrm{AS}$ \\
\hline & & & $x_{0 \mathrm{~d}}$ & & & & cure $_{\mathrm{I}} \times \mathrm{XY}$ & วหพา & 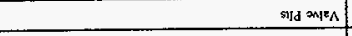 & $\triangle A F O X V I D Z$ & & 86 ᄉ1 \\
\hline & & & $\mathrm{x}_{\mathrm{d}}$ & & & & we: $\cdot x y$ & DHพา & $x_{d} \approx m ! S$ & atoxvidz & & $86 \mathrm{AI}$ \\
\hline & & & $x_{0 d}$ & & & & anter $: x V$ & วHพา & Ild somis & stoxvitz & & $86 \mathrm{XJ}$ \\
\hline & & & $\mathrm{xad}$ & & & & $w r_{j} \cdot x y$ & วHWT & ISd $\infty !+15$ & atoxviac & & $86 \mathrm{AJ}$ \\
\hline & & & $\mathrm{xad}$ & & & & weed:XV & วHWT & Fild anph & dAsoxvit $a$ & & $86 \mathrm{AJ}$ \\
\hline & & & $x_{\mathrm{Od}}$ & . & & & $\mathrm{wr}_{\mathrm{J}} \cdot \mathrm{xy}$ & วнพา & 1t: romis & asoxvitz & & $86 \times 3$ \\
\hline & & & $x_{0}$ & & & & uws $\mathrm{B}_{\mathrm{d}} \cdot \mathrm{XV}$ & JHWT & idd $\infty m 1 s$ & sroxvite & & $86 \mathrm{NA}$ \\
\hline & & & $x_{d d}$ & & & & une्s. $\times X V$ & วнพт & I.d xomsts & geoxvit & & $86 \mathrm{XI}$ \\
\hline & & & $x_{21}$ & & & & $t \times B_{\mathrm{S}} \cdot \mathrm{XV}$ & วHพา & जId xil $^{\prime} \wedge$ & dAzOXYIDz & & $86 \pi \mathrm{A}$ \\
\hline & & & $\infty$ & & & & & ОНพТ & syd dWnd snากNNY & wroxyin & & $86 \times 1$ \\
\hline $\begin{array}{l}\text { ONILVY } \\
\text { SISATIVY } \\
\text { ONILSIXI }\end{array}$ & $\begin{array}{l}\text { ONLLVY } \\
\text { NOILINONOO } \\
\text { XIITIOVI }\end{array}$ & $\begin{array}{l}\text { dnSDO } \\
\text { TYLOLL }\end{array}$ & 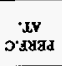 & 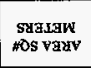 & $\begin{array}{l}\text { SnTd\&ns } \\
\text { yvax }\end{array}$ & $\begin{array}{l}\text { L'ing } \\
\text { dvax }\end{array}$ & Logroyd & vy.INoo & NoLLaIdosa & มML,ALINAaI & $\begin{array}{l}\text { zacos } \\
\text { x.LOI\&d }\end{array}$ & $\begin{array}{l}\text { garos } \\
\text { nxva }\end{array}$ \\
\hline
\end{tabular}




\begin{tabular}{|c|c|c|c|c|c|c|c|c|c|c|c|c|}
\hline $\begin{array}{l}\text { EVALU } \\
\text { SCHED }\end{array}$ & $\begin{array}{l}\text { PRIOITYY } \\
\text { SCORE }\end{array}$ & IDENTIFIER & DESCRIPTION & CONTRA & PROJECT & $\begin{array}{l}\text { YEAR } \\
\text { BUTLT }\end{array}$ & $\begin{array}{c}\text { YBAR } \\
\text { sURPLUS }\end{array}$ & $\begin{array}{l}\text { AREA SQA } \\
\text { METERS }\end{array}$ & $\begin{array}{c}\text { PERF.C } \\
\text { AT. }\end{array}$ & $\begin{array}{l}\text { TOTAL, } \\
\text { OCCUP }\end{array}$ & $\begin{array}{l}\text { FACILITY } \\
\text { CONDTION } \\
\text { RATING }\end{array}$ & $\begin{array}{l}\text { EXISTING } \\
\text { ANALYSIS. } \\
\text { RATING }\end{array}$ \\
\hline FY 98 & & 241AYIOIA & ENCASEMENT DUAL LEAK DETECTION PTT & IMHC & AY-FARM & & & & PCX & & & \\
\hline FY 98 & & 241 24YIOIB & ENCASEMENT DUAL LEAK DETECTION PTT & LMHC & AY-FARM & & & & $\mathrm{PCX}$ & & & \\
\hline FY 98 & & $241 \mathrm{AY} 102 \mathrm{~A}$. & LEAAK DETECTION PTT & LMHC & AY-FARM & & & & $\mathbf{P C X}$ & & & \\
\hline FY 98 & & 241AYISI & PUMP OUT PITS & LMHC & & & & & PCX & & & \\
\hline FY 98 & & 241AYISZ & SLUICE TRANSFER BOXES & LMHC & & & & & POX & & & \\
\hline FY 98 & & $241 \mathrm{AY} 401$ & $\begin{array}{l}\text { VENT RECIRCULATION EQUIPMENFVAULTVENT } \\
\text { RECIRCULATION EQUPMENTVAULT }\end{array}$ & LMHC & & & & 37 & $\mathrm{PCX}$ & & & \\
\hline FY 98 & & $241 \mathrm{AY} 402$ & VENT RECIRCULATION EQUIPMENT & LMHC & & & & 37 & $P C x$ & & & \\
\hline$F Y 98$ & & $241 \mathrm{AYSOI}$ & VALVE PTT & LMHC & & & & & $\mathrm{PCX}$ & & & \\
\hline FY 98 & & 241 24YYI & ELECTRICAL EQUIPMENT BUILDING $@ 241-C-106$ & LMHC & & & & & $\mathrm{PCX}$ & . & & \\
\hline FY 98 & & $24 I$ YYSIA & SEISMIC SHUTDOWN SYSTEM IA $\cong$ 241.C.106 & LMHC & & & & & $\mathrm{PCX}$ & & & \\
\hline FY 98 & & $241 \mathrm{AYSIB}$ & SEISMIC SHUTDOWN SYSTEM IB \& 241.C-106 & LMHC & & & & & $P C x$ & & & \\
\hline FY 98 & & $241 A Y 801$ & TANK FARM NSSTRUMENT HOUSE & PHMC & & & & 37 & $\mathrm{PCX}$ & & & \\
\hline FY 98 & & $241 \mathrm{AYBDAA}$ & AY TANK FARM & LMHC & & & & & $\mathrm{PCx}$ & & & \\
\hline FY 98 & & $2411 \mathrm{Z}$ & $\begin{array}{l}\text { WASTE DISPOSAL TANK FARM, } 2 \text { TANKS1 MGAL } \\
\text { EACHTANK FARM (2 TANKS)AZ TANK FARM }\end{array}$ & LMHC & PUREX & & & & $\mathrm{PCX}$ & & & ? \\
\hline FY 98 & & $241 \mathrm{AZO1A}$ & VALVE PTI & LMHC & & & & & $P O X$ & & & \\
\hline FY 98 & & 241AZO1B & VALVE PTT & LMHC & & & & & PCX & & & \\
\hline FY 98 & & 2AIAZOIC & VALVE PIT & LMHC & & & & & PCX & & & \\
\hline FY 98 & & 2AlAZISI & DNERTER STATION & LMHC & & & & & $\mathrm{PCx}$ & & & \\
\hline FY 98 & & $241 A Z 152$ & SLUICE TRANSFER BOX & LMHC & & & & & $\mathrm{PCX}$ & & & \\
\hline FY 98 & & 24 IAZIS3 & CONDENSATE VALVE PTT & LMHC & & & & & $\mathrm{PCx}$ & & & \\
\hline FY98 & & 241 AZIS4 & CONDENSATE PUMP PIT & LMHC & & & & & $\overline{P C x}$ & & & \\
\hline FY 98 & & $241 \mathrm{AZISS}$ & CONTAMINATED STORAGE PIT & LMHC & & & & & $\mathrm{PCX}$ & & & \\
\hline FY 98 & & 241 AZIS6 & MIXER PUMP SPEED CONTROLLER & LMHC & & & & & PCX & & & \\
\hline FY 98 & & $241 \wedge 2271$ & CHANGE HOUSECONTROL BUILDING & LMHC & & & & 459 & $\mathrm{PCx}$ & & & \\
\hline FY 98 & & 241 A2401 & VENT RECIRCULATION EQUIPMENT VAULT & LMHC & & & & 37 & $P C X$ & & & \\
\hline FY 98 & & 241 AZ402 & VENT RECIRCULATION EQUIPMENT VAULT & LMHC & & & & 37 & $\mathrm{PCX}$ & & & \\
\hline FX 98 & & $241 \mathrm{AZMO}$ & $\begin{array}{l}\text { STANDBYGENERATOR/COMPRESSOR/SERVICEBLD } \\
\text { GSTANDBY GEN/COMPSERVICE }\end{array}$ & LMHC & & & & & $\mathrm{PCX}$ & & & \\
\hline FY 98 & & $241 \mathrm{AZM2}$ & WASTE TANK VENTTLATION BUILDING & LMHC & & & & 929 & $\mathrm{PCx}$ & & & \\
\hline FY 98 & & $241 \mathrm{AZ2801}$ & EP BLDG & LMHC & & & & 36 & $P C X$ & & & \\
\hline FY 98 & & $241 \mathrm{AZ} 801 \mathrm{~A}$ & AZ TANK FARM & LMHC & & & & ss & $\mathrm{POX}$ & & & \\
\hline FY 98 & & $241 \mathrm{~B}$ & $\begin{array}{l}\text { WASTEDISPOSAL TANK FARM } 4 \text { ATSO000 } 12 \text { AT } \\
\text { 53300OGALTANK FARM (16 TANSS, } 5 \\
\text { DIVERSIONBOXES)B TANK FARMS }\end{array}$ & LMHC & & & & & $\mathrm{PCX}$ & & & \\
\hline FY 98 & & $24 \mid \mathrm{B} 1 \mathrm{S1}$ & DIVERSION BOXES & LMHC & B-Farm & & & & $\mathbf{P C x}$ & & & \\
\hline
\end{tabular}




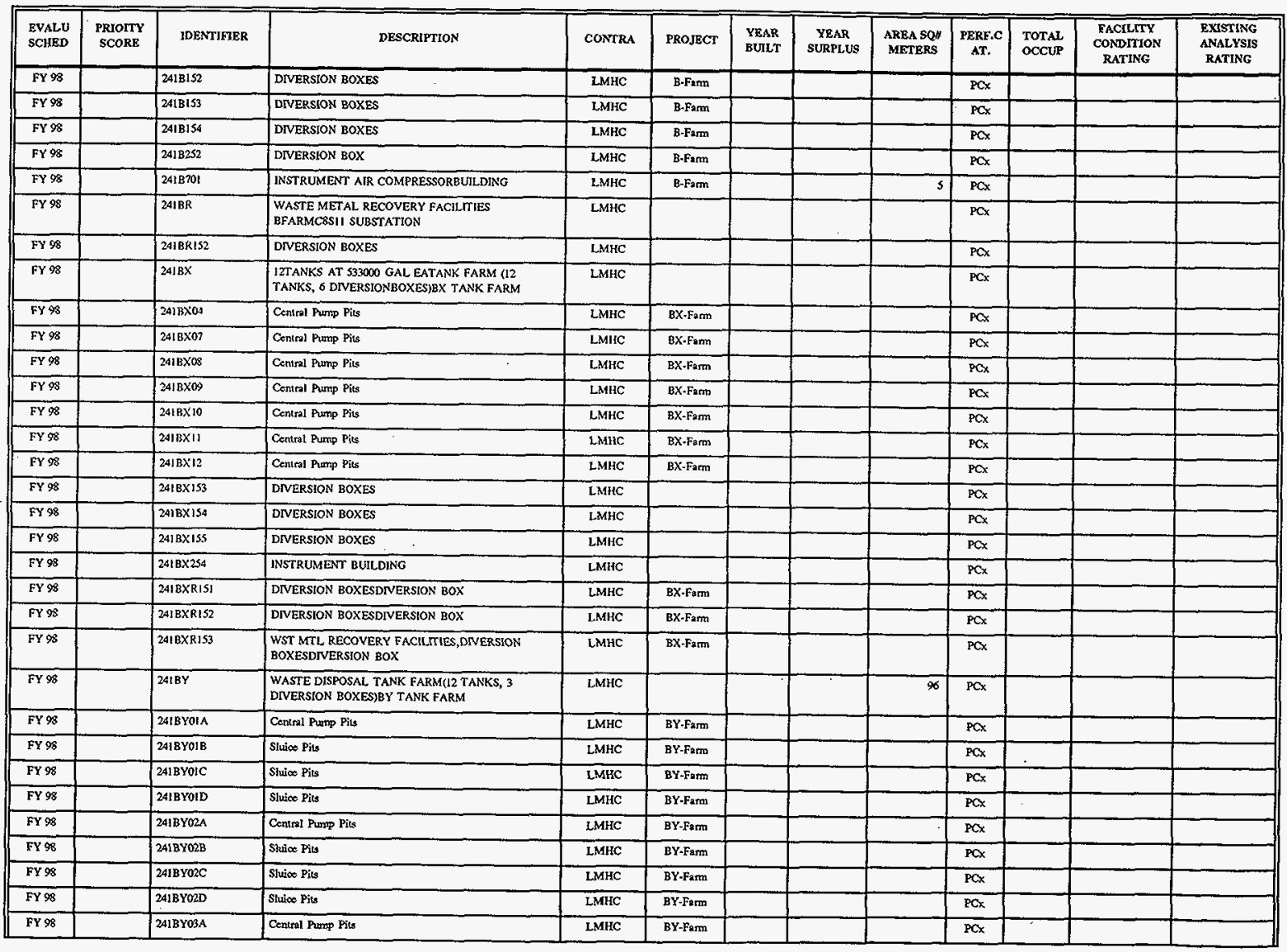




\begin{tabular}{|c|c|c|c|c|c|c|c|c|c|c|c|c|}
\hline $\begin{array}{l}\text { EVALU } \\
\text { SCHED }\end{array}$ & $\begin{array}{l}\text { PRIorry } \\
\text { SCORE }\end{array}$ & IDENTIFIRR & DESCRIPTION & CONTRA & PROJECT & $\begin{array}{l}\text { YEAR } \\
\text { BUILT }\end{array}$ & $\begin{array}{c}\text { YEAR } \\
\text { SURPLUS }\end{array}$ & $\begin{array}{l}\text { AREA SQH } \\
\text { METERS }\end{array}$ & $\begin{array}{c}\text { PERF.C } \\
\text { AT. }\end{array}$ & $\begin{array}{l}\text { TOTAX } \\
\text { OCCUP }\end{array}$ & $\begin{array}{l}\text { FACILITY } \\
\text { CONDITION } \\
\text { RATING }\end{array}$ & $\begin{array}{l}\text { EXISTING } \\
\text { ANALYSIS } \\
\text { RATING }\end{array}$ \\
\hline FY 98 & & $241 \mathrm{BX} 03 \mathrm{~B}$ & Shliose Pita & LMHC & BY.Fam & & & & $\mathrm{PCX}$ & & & \\
\hline FY 98 & & $241 \mathrm{BY} 03 \mathrm{C}$ & Shivoo Pits & LMHC & BY:Fam & & & & $\mathrm{PCX}$ & & & \\
\hline FY 98 & & 241BY03D & Shijoc Pists & LMHC & BY.Farm & & & & $\mathrm{PCX}$ & & & \\
\hline FY 98 & & $241 \mathrm{BY} 04 \mathrm{~A}$ & Central Pump Pits & LMHC & BY-Farm & & & & $P C_{x}$ & & & \\
\hline FY 98 & & $241 \mathrm{BY} 04 \mathrm{~B}$ & Sluifoc Pits & LMHC & BY.Fam & & & & $\mathrm{PCx}$ & & & \\
\hline FY 98 & & $241 \mathrm{BY} 04 \mathrm{C}$ & Stuice Pits & LMHC & BY-Fam & & & & $\mathrm{PCx}$ & & & \\
\hline FY 98 & & $241 \mathrm{BYOSD}$ & Sluive Pits & LMHC & BY.Farm & & & & $\mathrm{PCX}$ & & & \\
\hline FY 98 & & 241BYOSA & Central Pump Pits & LMHC & BY-Farm & & & & $P C X$ & & & \\
\hline FY 98 & & $201 B Y O S B$ & Stluios Pits & LMHC & BY.Farm & & & & $\mathrm{PCX}$ & & & \\
\hline FY 98 & & 241 BYOSC & Sluice Pits & LMHC & BY.F $\mathrm{xmm}$ & & & & $P C X$ & & & \\
\hline FY 98 & & $2 A 1 B Y O S D$ & Sluice Pits & LMHC & BY.Farn & & & & $\mathrm{PCX}$ & & & \\
\hline FY 98 & & $241 \mathrm{BY} 06 \mathrm{~A}$ & Central Rump Pits & LMHC & BY-Fam & & & & $\mathrm{PCX}$ & & & \\
\hline FY 98 & & $241 \mathrm{BY} 06 \mathrm{~B}$ & Stuice Pits & LMHC & BY.Fam & & & & $\mathrm{PCx}$ & & & \\
\hline FY 98 & & $2418 Y 000$ & Sluíce Pits & LMHC & BY-Fam & & & & $P C x$ & & & \\
\hline FY 98 & & $24[\mathrm{BY} Y 6 \mathrm{CO}$ & Sluire Pits & LMHC & BY-Farm & & & & $P C x$ & & & \\
\hline FY 98 & & $241 \mathrm{BY} 07 \mathrm{~A}$ & Ceniral Pump Pists & LMHC & BY-Farm & & & & $P C X$ & & & \\
\hline FY 98 & & $241 \mathrm{~B} Y 07 \mathrm{~B}$ & Stứos Pists & LMHC & BY-Fann & & & & $\mathrm{PCx}$ & & & \\
\hline FY 98 & & $241 \mathrm{BY} 07 \mathrm{C}$ & Sluive Pits & EMHC & BY-Fatm & & & & $\mathrm{PCX}$ & & & \\
\hline FY 98 & & $241 \mathrm{BY} 070$ & Sluies Pists & LMHC & BY.Fam & & & & $P C x$ & & & \\
\hline FY 98 & & $241 \mathrm{BYOSA}$ & Contral Pump Pits & LMAHC & BY.Fam & & & & $\mathrm{PCX}$ & & & \\
\hline FY 98 & & $241 \mathrm{BYOSB}$ & Sluios Pists & LMHC & BY-Fam & & & & $\mathrm{PCX}$ & & & \\
\hline FY 98 & & $241 \mathrm{BYOBC}$ & Slwioc Pits & LMHC & BY.Frm & & & & $\mathrm{PCx}$ & & & \\
\hline$F \times 98$ & & $241 \mathrm{BYOSD}$ & Shuice Pits & LMHC & BY.Famm & & & & PCX & & & \\
\hline FY 98 & & $241 \mathrm{~B} Y 99 \mathrm{~A}$ & Central Pump Pils & LMHC & BY-Fatm & & & & $\mathrm{PCX}$ & & & \\
\hline FY 98 & & $241 \mathrm{BYOSB}$ & Sluice Pits & LMHC & $\mathrm{BY}$ - Farm & & & & $\mathrm{PCx}$ & & & \\
\hline FY 98 & & $2 A 1 \mathrm{BYOSC}$ & Sluive Pits & LMHC & BY-Farm & & & & $\mathrm{PCX}$ & & & \\
\hline FY 98 & & $241 \mathrm{BYO9D}$ & Sluioe Pits & LMHC & BY-Frm & & & & $\mathrm{PCx}$ & & & \\
\hline FY 98 & & $241 \mathrm{BY} 10 \mathrm{~A}$ & Central Prmp Pits & LMHC & BY.Farm & & & & $\mathrm{PCX}$ & & & \\
\hline FY 98 & & $2418 Y 10 \mathrm{~B}$ & Sluise Pits & LMHC & BY-Fam & & & & $\mathrm{PCX}$ & & & \\
\hline FY 98 & & $241 \mathrm{BY} 10 \mathrm{C}$ & Sluico Pits & LMHC & BY-Frmm & & & & $P C X$ & & & \\
\hline FY 98 & & $2418 \times 100$ & Sluioe Pits & LMHC & BY.Farm & & & & $P C X$ & & & \\
\hline FY 98 & & $241 \mathrm{BY} I 1 \mathrm{~A}$ & Central Purmp Pits & LMHC & BX-Fam & & & & $\mathrm{PCX}$ & & & \\
\hline FY 98 & & 241BY11B & Slứce Pits & LMHC & BY-Farm & & & & $\mathrm{PCx}$ & & & \\
\hline FY 98 & & $241 \mathrm{BY} 11 \mathrm{C}$ & Sthioo Pils & LMHC & BY-Fratm & & & & $\mathrm{PCX}$ & & & \\
\hline FY 98 & & 2418YIID & Sluive Pits & LMHC & BY-Fam & & & & $\mathrm{PCx}$ & & & \\
\hline
\end{tabular}




\begin{tabular}{|c|c|c|c|c|c|c|c|c|c|c|c|c|}
\hline $\begin{array}{l}\text { EVALU } \\
\text { SCHED }\end{array}$ & $\begin{array}{l}\text { PRIOITY } \\
\text { SCORE }\end{array}$ & IDENTIFLER & DESCRIPTION & CONTRA & PROJECT & $\begin{array}{l}\text { YEAR } \\
\text { BUHLT }\end{array}$ & $\begin{array}{c}\text { YBAR } \\
\text { SURPLUS }\end{array}$ & $\begin{array}{l}\text { AREA SQ } / \\
\text { METERS }\end{array}$ & $\begin{array}{c}\text { PERF.C } \\
\text { AT. }\end{array}$ & $\begin{array}{l}\text { TOTAL } \\
\text { OCCUP }\end{array}$ & $\begin{array}{c}\text { FACIIITY } \\
\text { CONDPIION } \\
\text { RATING }\end{array}$ & $\begin{array}{l}\text { EXISTING } \\
\text { ANALYSIS } \\
\text { RATING }\end{array}$ \\
\hline FY 93 & & $241 \mathrm{BY} 12 \mathrm{~A}$ & Central Premp Pits & LMHC & BY-Famm & & & & $\mathrm{PCx}$ & & & \\
\hline FY 98 & & $24 \mathrm{LBY} 12 \mathrm{~B}$ & Stuice Pits & LMHC & BY.Farm & & & & $P C_{x}$ & & & \\
\hline FY 98 & & $241 \mathrm{BY} 12 \mathrm{C}$ & Sluice Pits & LMHC & BY-Fam & & & & $P C x$ & & & \\
\hline FY 98 & & $241 \mathrm{BY} 12 \mathrm{D}$ & Slưfeo Pits & LMHC & BY-Fam & & & & $P C X$ & & & \\
\hline FY 98 & & $241 B Y 254$ & CONTROL HOUSE AND COMPRESSOR, ITSZ & LMHC & BY.Famm & & & 68 & $\mathrm{PCX}$ & & & \\
\hline FY 98 & & $241 \mathrm{BY} 301$ & $\begin{array}{l}\text { CONTROL HOUSE IN TANKSOLIDIFICATIONS } \\
\text { ITSINSTRUMENT CONTROL }\end{array}$ & LMHC & BV-Fam & & & 10 & $\mathrm{PCX}$ & & & \\
\hline FY 98 & & $241 \mathrm{BY} 302$ & COMPRESSOR HOUSE, ITSI & LMHC & BY-Fam? & & & 94 & $\overline{P C X}$ & & & \\
\hline FY 98 & & $24 \mathrm{BY} 302 \mathrm{~A}$ & $\begin{array}{l}\text { COMPRESSED AIR STATIONCOMPRESSED AIR } \\
\text { STATION }\end{array}$ & LMHC & & & & & $P O X$ & & & \\
\hline FY $\$ 8$ & & $241 \mathrm{BVR}$ & WASTE MET AL RECOVERY FACILIIIES,BY FARM & LMHC & & & & & $\mathrm{PCx}$ & & & \\
\hline FY 98 & & $\sqrt{241 \mathrm{BYR} 152}$ & DNERSION BOXES & LMHC & BY-Farm & & & & $\mathrm{PCx}$ & & & \\
\hline FY 98 & & 24 B BYR 153 & DNERSLON BOXES & LMHC & BY-Famm & & & & $\mathrm{PCX}$ & & & \\
\hline FY 98 & & 241 BYRISA & DNERSION BOXES & LMHC & BY-Fam & & & & PCX & & & \\
\hline FY 98 & & $241 \mathrm{BYTK} 2$ & SOAKRRINSE TANK & LMHC & & & & & $\mathrm{PCX}$ & & & \\
\hline FY 98 & & $241 \mathrm{BVTK} 302 \mathrm{C}$ & ACID NEUTRALIZATION TANK & L.MHC & & & & & $\mathrm{PCx}$ & & & \\
\hline FY 98 & & $241 \mathrm{C}$ & $\begin{array}{l}\text { TANK FARMS (16 TANKS, } 6 \\
\text { DNNERSIONBOXES)C-TANK FARM }\end{array}$ & LMHC & PUREX & & & & $\mathrm{PCx}$ & & & \\
\hline FY 98 & & $2410202 A$ & CENTRAL PUMP PTSS & LMHC & C.Fam & & & & $\mathrm{PCx}$ & & & \\
\hline FY 98 & & $241 \cos A$ & CENTRAL PUMP PTTS & LMHC & C.Farm & & & & $\mathrm{PCX}$ & & & \\
\hline FY 98 & & $241004 \mathrm{~A}$ & CENTRAL PUMP PITS & LMHC & C.Fam & & & & $\mathrm{PCX}$ & & & \\
\hline FY 98 & & $241 \cos \mathrm{A}$ & CENTRAL PUMP PITS & LMHC & c. $\sqrt{2 m m}$ & & & & $\mathrm{PCx}$ & & & \\
\hline FY 93 & & $241006 \mathrm{~A}$ & CENTRAL PUMP PTTS & LMHC & C.Fam & & & & $\mathrm{PCx}$ & & & \\
\hline FY 98 & & $241 \mathrm{C151}$ & DIVERSION BOXES & LMHC & C.Farm & & & & $P C x$ & & & \\
\hline FY98 & & $24 \mathrm{CCIS2}$ & DNVERSION BOXES & LMHC & C.Fam & & & & $P C_{x}$ & & & \\
\hline FY98 & & $241 \mathrm{ClS3}$ & DIVERSION BOXES & LMHC & C.Frm & & . & & $P C x$ & & & \\
\hline FY 98 & & $241 \mathrm{C} 154$ & DIVERSION BOXES & LMHC & CFatrm & & & & $P C$ & & & \\
\hline FY 98 & & 2410252 & DIVERSION BOXES & LMHC & C.Farm & & & & PCx & & & \\
\hline FY 98 & & $241 \mathrm{CS} 1$ & ELECTRICAL EQUIPMENT @ 241-C-106 & LMHC & & & & & $\mathrm{PCX}$ & & & \\
\hline FY 98 & & $241 \mathrm{CS} 1 \mathrm{~A}$ & SEISMIC SHUTDOWN SYSTEM IA $@ 241$-C-106 & LMHC & & & & & $\mathrm{PCx}$ & & & \\
\hline FY 98 & & $241 \mathrm{CSIB}$ & SEISMIC SHUTDOWN SYSTEM $1 \mathrm{~B} \otimes 241 \cdot \mathrm{C}-106$ & LMHC & & & & & PCX & & & \\
\hline FY 98 & & $24 \mathrm{KCB}$ & $\begin{array}{l}\begin{array}{l}\text { CFARM SERVICE BUILDINGCFARM SERVICE } \\
\text { BULDDNG }\end{array} \\
\end{array}$ & LMHC & & & & & $P C X$ & & & \\
\hline FY 98 & & 241090 & AIR COMPRESSOR FACILITY & LMHC & & & & 19 & $\mathrm{PCX}$ & & & \\
\hline FY 98 & & 241091 & $\begin{array}{l}\text { 241-C-106 VENTILATION PROCESS BLDGC-FARM } \\
\text { VENTLAITON }\end{array}$ & LMAC & & & & & $\mathrm{PCX}$ & & & \\
\hline FY 98 & & $241 C R$ & METAL RECOVERY FACILITIESC4684. SUBSTATION & LMHC & & & & & $P C X$ & & & \\
\hline
\end{tabular}




\begin{tabular}{|c|c|c|c|c|c|c|c|c|c|c|c|c|}
\hline $\begin{array}{l}\text { EVALU } \\
\text { SCHED }\end{array}$ & $\begin{array}{l}\text { PRIOITY } \\
\text { SCORE }\end{array}$ & IDENTIFER & DESCRIPTION & CONTRA & PROJECT & $\begin{array}{l}\text { YEAR } \\
\text { BUILT }\end{array}$ & $\begin{array}{c}\text { YEAR } \\
\text { SURPLUS }\end{array}$ & $\begin{array}{l}\text { AREA SO } \\
\text { METERS }\end{array}$ & $\begin{array}{l}\text { PRRF.C } \\
\text { AT. }\end{array}$ & $\begin{array}{l}\text { TOTAL } \\
\text { OCCUP }\end{array}$ & $\begin{array}{l}\text { FACIITIY } \\
\text { CONDRTION } \\
\text { RATING }\end{array}$ & $\begin{array}{l}\text { EXISTING } \\
\text { ANALYSIS } \\
\text { RATING }\end{array}$ \\
\hline FY 98 & & 241CR151 & METAL RECOVERY FACIIITIES DIVERSION BOX & IMHC & C.Farm & & & & $\mathrm{PCX}$ & & & \\
\hline FY 98 & & 241 CR152 & METAL RECOVERY FACILTIES DNERSION BOX & IMHC & C.Farm & & & & 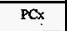 & & & \\
\hline FY 98 & & $24 \mathrm{ICRIS3}$ & METAL RECOVERY FACILTIES DNERSION BOX & IMHC & C.Fam & & & & $\mathrm{PCX}$ & & & \\
\hline FY 98 & & $241 \mathrm{CR} 271$ & $\begin{array}{l}\text { WASTE DISPOSAL CONTROL HOUSE,241C TANK } \\
\text { FARM }\end{array}$ & IMHC & C.Farm & & & 123 & $\mathrm{PCx}$ & & & \\
\hline FY 98 & - & 291ERISI & EXPORT LINE, DNVERSION BOX & LMHC & & & & & $\mathrm{PCX}$ & & & \\
\hline FY 98 & & 2A1ERIS2 & EXPORT LINE, DNERSION BOX & LMHC & & & & & $\mathrm{PQx}$ & & & \\
\hline FY 98 & & 241ERIS3 & EXPORT LINE, DIVERSION BOX & LMHC & & & & & $\mathrm{PCX}$ & & & \\
\hline FY 98 & & 24IERISA & EXPORT LINE, DJVERSION BOX & LMHC & & & & & $\mathrm{PCx}$ & & & \\
\hline FY 98 & & 24 IER311 & CATCH TANK & LMHC & & & & & $\mathrm{PCx}$ & & & \\
\hline FY 98 & & $241 \mathrm{EW} 151$ & WASTE EXPORT LINES, DVVERSION BOX & LMHC & & & & & $P C x$ & & & \\
\hline FY98 & & 2415 & $\begin{array}{l}\text { 12TANKS, 7S8,OOO GAL. EATANK FARM (12 TANKS, } \\
2 \text { DIVERSSONBOXESSS.TANK FARM }\end{array}$ & LMHC & & & & & $\mathrm{PCX}$ & & & \\
\hline FY 98 & & $24 \mid S 151$ & DIVERSION BOX & LMHC & & & & & $\mathrm{PC} x$ & & & \\
\hline FY 98 & & 2415152 & DIVERSION BOX & LMHC & & & & & $\mathrm{PCX}$ & & & \\
\hline FY 98 & & $24152 \pi$ & ELECTRICAL AND INSTRUMENTCONTROL HOUSE & LMHC & & & & 36 & $\mathrm{PCX}$ & & & \\
\hline$\overline{\mathrm{FY} 98}$ & & $2415271 \mathrm{~A}$ & INSTRUMENT HOUSE & LMHC & $\begin{array}{l}\text { SX-FARM } \\
\end{array}$ & & & & $P C x$ & & & \\
\hline FY 98 & & $2415271 \mathrm{~B}$ & INSTRUMENT HOUSE & LMHC & SX-FARM & & & & $\mathrm{PCx}$ & & & \\
\hline FY 98 & & 2415504 & CATCH TANK & LMHC & & & & & $P C X$ & & & \\
\hline$F Y 98$ & & $241 \mathrm{SA}$ & VALVE PT & LMHQC & $\begin{array}{l}\text { S.FARM } \\
\end{array}$ & & & & PCX & & & \\
\hline FY'98 & & $2415 B$ & VALVE PTT & LMHC & S-FARM & & & & $\mathrm{PCx}$ & & & \\
\hline FY 98 & & $241 S C$ & VALVE PTS & LMHC & S.FARM & & & & PCX & & & \\
\hline FY 98 & & 24ISD & VALVE PT & LMHC & S-FARM & & & & $P C x$ & & & \\
\hline FY 98 & & $2415 X$ & $\begin{array}{l}\text { WISTANKS,IM GAL EACHTANK FARM (IS TANKS, } 2 \\
\text { DIVERSLONBOXES)SX.TANK FARM }\end{array}$ & LMHC & . & & & & $P C x$ & & & \\
\hline FY 98 & & $241 \mathrm{SX} 106$ & \begin{tabular}{|l} 
STACK AND FLLTER \\
\end{tabular} & LMHC & & & & & $\mathrm{PCx}$ & & & \\
\hline FY98 & & $2415 \times 107$ & INSTRUMENT SHACK & LMHC & & & & & $\mathrm{FCx}$ & & & \\
\hline FY 98 & & $241 S \times 108$ & INSTRUMENT SHACK & LMHC & & & & & $\mathrm{PCx}$ & & & \\
\hline FY 98 & & $2415 \times 109$ & INSTRUMENT SHACK & LMHC & & & & & $\mathrm{PCx}$ & & & \\
\hline FY 98 & & $2415 \times 110$ & INSTRUMENT SHACK & LMHC & & & & & $\mathrm{PCx}$ & & & \\
\hline FY 98 & & $2415 \times 111$ & INSTRUMENT SHACK & LMHC & & & & & $P C X$ & & & \\
\hline FY 98 & & $241 \mathrm{SX} 112$ & INSTRUMENT SHACK & LMHC & & & & & $\mathrm{PCX}$ & & & \\
\hline FY98 & & $2415 \times 114$ & INSTRUMENT SHACK & LMHC & & & & & $\mathrm{PC} x$ & & & \\
\hline FY 98 & & $241 \mathrm{SX} 151$ & DIVERSION BOX & LMHC & SX.FARM & & & & $\mathrm{PCX}$ & & & \\
\hline FY 98 & & $2415 \times 152$ & DIVERSION BOX & IMHC & SX-FARM & . & & & $P C x$ & & & \\
\hline FY 98 & & $2415 \times 271$ & TANK FARM CONTROL HOUSE & LMHC & SX-FARM & & & 36 & $\mathrm{PCX}$ & & & \\
\hline
\end{tabular}




\begin{tabular}{|c|c|c|c|c|c|c|c|c|c|c|c|c|}
\hline $\begin{array}{l}\text { EVALU } \\
\text { SCHED }\end{array}$ & $\begin{array}{l}\text { PRIOITY } \\
\text { SCORE }\end{array}$ & IDENTIFIER & DESCRIPTION & CONTRA & PROJECT & $\begin{array}{l}\text { YEAR } \\
\text { BUILT }\end{array}$ & $\begin{array}{l}\text { YEAR } \\
\text { SURPLUS }\end{array}$ & $\begin{array}{l}\text { AREA SQA } \\
\text { METERS }\end{array}$ & $\begin{array}{l}\text { PERF.C } \\
\text { AT. }\end{array}$ & $\begin{array}{l}\text { Total } \\
\text { OCcur }\end{array}$ & $\begin{array}{l}\text { FACILITY } \\
\text { CONDITION } \\
\text { RATING }\end{array}$ & $\begin{array}{l}\text { EXISTING } \\
\text { ANALYSIS } \\
\text { RATING }\end{array}$ \\
\hline FY 98 & & $241 \mathrm{SX} 281$ & EMERGENCY COOLLING WATER PUMPHOUSE & LMHC & & & & 35 & $\mathrm{PCx}$ & & & \\
\hline FY 98 & & $2415 \times 500$ & LATERAL SHACK NUMBER I & LMHC & & & & & POX & & & \\
\hline FY 98 & & $2415 \times 501$ & LATERAL SHACK NUMBER 2 & LMHC & & & & & $P C X$ & & & \\
\hline FY 98 & & $2415 \times 502$ & LATERAL SHACK NUMBER 3 & LMHC & & & & & $\mathrm{PCX}$ & & & \\
\hline FY 98 & & $2415 \times 503$ & LATERAL SHACK NUMBER 4 & LMHC & & & & & $\mathrm{PCX}$ & & & \\
\hline FY 98 & & $24 ! 5 \times 701$ & WASTE DISPOSAL CONDENSER HOUSE & LMHC & & & & 49 & $\mathrm{PCX}$ & & & \\
\hline FY98 & & $2415 \times \mathrm{A}$ & VALVE PT & LMHC & SX-FARM & & & & $\mathrm{PCX}$ & & & \\
\hline FY 98 & & $241 \mathrm{SXB}$ & VALVE PTT & LMHC & SX-FARM & & & & PCX & & & \\
\hline FY 98 & & $241 \mathrm{SY}$ & $\begin{array}{l}\text { WASTE DISPOSAL TANK FARMTTANK FARM } 3 \\
\text { TANKSSYY-TANK FARM }\end{array}$ & LMHC & & & & & PCX & & & \\
\hline FY 98 & & 24 ISYOIA & CENTRAL PUMP PTT & LMIIC & SY-FARM & & & & $\mathrm{POX}$ & & & \\
\hline FY 98 & & 241 SYO1B & ANNULLUS PUMAP PTT & LMIIC & SY-FARM & & & & $\mathrm{PCx}$ & & & \\
\hline FY 98 & & $2415 Y 02 A$ & CENTRAL PUMP PTT & LMHC & SY-FARM & & & & $\mathrm{PCX}$ & & & \\
\hline FY $\mathscr{B}$ & & $24 I S Y 02 B$ & ANNULUS PUMP PTT & LMHC & SY-FARM & & & & PCX & & & \\
\hline FY 98 & & $2 A I S Y 02 D$ & DRAIN PTT & LMHC & SY.FARM & & & & PCX & & & \\
\hline FY 98 & & 241SYO2E & FEED PUMP PIT & LMHC & SY.FARM & & & & $\mathrm{PCX}$ & & & \\
\hline FY 98 & & $241 S Y 03 A$ & CENTRAL PUMP PTT & LMHC & SY-FARM & & & & $\mathrm{PCX}$ & & & \\
\hline FY 98 & & $241 S Y 03 B$ & ANNUL,US PUMP PTT & LMAC & SYFARM & & & & $\mathrm{PCX}$ & & & \\
\hline FY 98 & & $2415 Y 271$ & INSTRUMENT AND ELECTRICALCONTROL HOUSE & $\begin{array}{l}\text { LMHC } \\
\end{array}$ & & & & 35 & $\overline{\mathrm{PCX}}$ & & & \\
\hline FY 98 & & $2415 Y 272$ & ELECTRICAL BUILDING & LMHC & & & & 18 & $\mathrm{PCX}$ & & & \\
\hline FY 98 & & $2415 Y 273$ & BACKUP GENERATOR BUILDING SYTANK FARM & LMHC & & & & & $\mathrm{PCX}$ & & & \\
\hline FY 98 & & $241 S Y 274$ & GAS MONITORING SHELTER & LMHC & & & & & $\mathrm{PCX}$ & & & \\
\hline FY 98 & & $2415 Y 275$ & GAS MONITORING SHELTER & IMHC & & & & & $\mathbf{P C X}$ & & & \\
\hline FY 93 & & $2415 Y 276$ & DACS UPS SKID & LMHC & & & & & PCX & & & \\
\hline FY 98 & & $241 S Y 701$ & TANK FARMSY FARM & LMHC & & & & & $\overline{P C x}$ & & & \\
\hline FY 98 & & $241 \mathrm{SYA}$ & VALVE PTS & LMHC & SY-FARM & & & & $\mathrm{PCX}$ & & & \\
\hline FY 98 & & $2415 Y 3$ & VALVE PTT & LMHC & SY.FARM & & & & $\overline{P C X}$ & & & \\
\hline FY 98 & & $2415 \mathrm{YCOBI}$ & CLEANOUT BOX I & LMHC & SY-FARM & & & & $P C X$ & & & \\
\hline FY 98 & & $2415 Y \mathrm{YCOB2}$ & CLEANOUT BOX 2 & LMHC & SY.FARM & & & & $\mathrm{PCX}$ & & & \\
\hline FY98 & & $2415 \times C O B 3$ & CLEANOUT BOX 3 & LMHC & SY.FARM & & & & $\mathrm{PCX}$ & & & \\
\hline FX 98 & & $2415 \times C O B A$. & CLEANOUT BOX 4 & LMHC & SY.FARM & & & & $\mathrm{PCX}$ & & & \\
\hline FY 98 & & 24IIYYCOBS & CLEANOUT BOX 5 & LMHC & SY-FARM & & & & $\overline{P C x}$ & & & \\
\hline FY 98 & & $2415 \times C O B \sigma$ & CLEANOUT BOX 6 & LMHC & SYFARM & & & & $\mathrm{PCX}$ & & & \\
\hline FY 98 & & $241 \mathrm{~T}$ & $\begin{array}{l}4 \text { 50,000,12 533,000TANK FARM (16 TANKS, } 6 \\
\text { DVERSIONBOXEST-TANK FARM }\end{array}$ & LMHC & TX-FARM & & & & PCX. & & & \\
\hline
\end{tabular}




\begin{tabular}{|c|c|c|c|c|c|c|c|c|c|c|c|c|}
\hline $\begin{array}{l}\text { EVALU } \\
\text { SCHED }\end{array}$ & $\begin{array}{l}\text { PRIOITY } \\
\text { SCORE }\end{array}$ & IDENTIFIER & DESCRIPTION & CONTRA & PROJECT & $\begin{array}{l}\text { YEAR } \\
\text { BUILT }\end{array}$ & $\begin{array}{l}\text { YEAR } \\
\text { SURPLUS }\end{array}$ & $\begin{array}{l}\text { AREA SOF } \\
\text { METERS }\end{array}$ & $\begin{array}{c}\text { PERF.C } \\
\text { AX. }\end{array}$ & $\begin{array}{l}\text { roraL } \\
\text { OCCUP }\end{array}$ & $\begin{array}{l}\text { FACILITY } \\
\text { CONDITION } \\
\text { RATING }\end{array}$ & $\begin{array}{l}\text { EXISTING } \\
\text { ANALYSSIS } \\
\text { RATING }\end{array}$ \\
\hline FY 98 & & $241 \mathrm{TI}$ & DIVERSION BOX & LMHC & & & & & $\mathrm{PCX}$ & & & \\
\hline FY 98 & & 291T151 & DIVERSION BOXES & LMHC & T.FARM & & & & $\mathrm{PCX}$ & & & \\
\hline FY 98 & & 241 1r132 & DNERSION BOX & LMHC & & & & & $\mathrm{PCX}$ & & & \\
\hline FY 98 & & 2417153 & DNVERSION BOX & LMHC & & & & & $\mathrm{PCx}$ & & & \\
\hline FY 98 & & 2417252 & DIVERSION BOX & LMHC & & & & & $\mathrm{PCx}$ & & & \\
\hline FY98 & & 2447601 & CHEMICAL MAKE UP BULLDING & LMHC & & & & 62 & $\mathrm{PCX}$ & & & \\
\hline FY 98 & & 2417201 & COMPRESSOR BULLDING & LMHC & & & & & 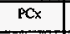 & & & \\
\hline FY 98 & & $241 T R$ & WASTE METAL RECOVERY FACILTIES,T FARM & LMIIC & & & & & $\mathrm{PCX}$ & & & \\
\hline$\overline{\text { FY } 98}$ & & 241TRIS2 & DNVERSLON BOXES & LMHC & $\begin{array}{l}\text { T-FARM } \\
\end{array}$ & & & & $\mathrm{PCX}$ & & & \\
\hline FY 9 & & 2AITRIS3 & DVVERSION BOXES & LMHC & T.FARM & & & & $\mathrm{PCx}$ & & & \\
\hline FY 98 & & $241 T x$ & $\begin{array}{l}\text { I8TANKS 758,000 GALTANK FARM (18 TANKS, } 4 \\
\text { DIVERSIONBOXES)TX-TANK FARM }\end{array}$ & LMHC & & & & & PCX & & & \\
\hline FY 98 & & $241 T X 152$ & DIVERSION BOXES & LMHC & TXFARM & & & & $\mathrm{PCX}$ & & & \\
\hline FY 98 & & $241 \mathrm{TX} 153$ & DNERSION BOXES & LMHC & TX-FARM & & & & $\mathrm{PCX}$ & & & \\
\hline FY 98 & & $241 \mathrm{TX154}$ & DNERSION BOXES & LMHIC & TX.FARM & & & & $P C x$ & & & \\
\hline FY 98 & & $241 \mathrm{TXISS}$ & DNERSION BOXES & LMHC & TX.FARM & & & & $\mathrm{PCx}$ & & & \\
\hline FY 98 & & $241 \mathrm{~T} \times 302 \mathrm{C}$ & CATCH TANK & LMHC & TX-FARM & & & & $\mathrm{PCx}$ & & & \\
\hline FY 98 & & $2417 \times 701$ & COMPRESSOR BUILDING & LMHC & & & & & PCX & & & \\
\hline FY 98 & & $241 \mathrm{TXR}$ & $\begin{array}{l}\text { WASTE METAL RECOVERY FACILTTES,TX } \\
\text { FARMVAULT }\end{array}$ & LMHC & & & & & PCX & & & \\
\hline FY 98 & & 241TXR151 & DNVERSION BOXES & LMHC & TX.FARM & & & & $\mathrm{PCX}$ & & & \\
\hline FY 98 & & 241 XXR1S2 & DVERSION BOXES & LMHC & TX.FARM & & & & $\mathrm{PCx}$ & & & \\
\hline FY 98 & & 24,TXR153 & DIVERSION BOXES & LMHC & TX.FARM & & & & $\mathrm{PCx}$ & & & \\
\hline FY 98 & & $241 \mathrm{TY}$ & $\begin{array}{l}\text { 6 TANKST58,00 GALTANK FARMS I6 TANKS, I } \\
\text { DNERSIONOX)TYYTANK FARM }\end{array}$ & LMHC & & & & & PCX & & & \\
\hline FY 98 & & 241 TY153 & DIVERSHON BOXES & DMHC & TY.FARM & & & & $\mathrm{PCx}$ & & & \\
\hline FY 98 & & 2410 & $\begin{array}{l}\text { 4 50,000, 12 533,000 GALTANK FARM (16 TANKS, } 8 \\
\text { DNVERSIONBOXESYU-TANK FARM }\end{array}$ & LMHC & & & & & $\overline{P C x}$ & & & \\
\hline FY 98 & & 2A1U151 & DVVERSION BOXES & IMHC & U.FARM & & & & $\mathrm{PCX}$ & & & \\
\hline FY 98 & & $241 U 152$ & DIVERSION BOXES & LMHC & L-FARM & & & & $\overline{P C x}$ & & & \\
\hline FY 98 & & $241 \mathrm{U} 153$ & DIVERSION BOXES & LMHC & U-FARM & & & & PCx & & & \\
\hline FY 98 & & 2414252 & DIVERSION BOXES & LMHC & U-FARM & & & & $\mathrm{PCx}$ & & & \\
\hline FY 98 & & $241 \mathrm{U271}$ & U FARM CONTROL HOUSE & LMHC & & & & 22 & $\mathrm{PCx}$ & & & \\
\hline FY 98 & & $241 \cup 301$ & CATCH TANK & LMHC & & & & & $\mathrm{PCx}$ & & & . \\
\hline FY 98 & & 2410201 & INSTRUMENT AIR COMPRESSOR HOUSE & LMHC & & & & 4 & $P C x$ & & & \\
\hline FY 98 & & $241 \mathrm{VA}$ & VALVE PIT & LMHC & U-FARM & & & & $\mathrm{PCx}$ & & & \\
\hline
\end{tabular}




\begin{tabular}{|c|c|c|c|c|c|c|c|c|c|c|c|c|}
\hline $\begin{array}{l}\text { EVALU } \\
\text { SCHED }\end{array}$ & $\begin{array}{l}\text { PRIOITY } \\
\text { SCORE }\end{array}$ & IDENTIFTER & DESCRIPTION & CONTRA & PROJECT & $\begin{array}{l}\text { YEAR } \\
\text { BUILT }\end{array}$ & $\begin{array}{l}\text { YEAR } \\
\text { SURPLUS }\end{array}$ & $\begin{array}{l}\text { AREA SQ\# } \\
\text { METERS }\end{array}$ & $\begin{array}{c}\text { PERF.C } \\
\text { AT. }\end{array}$ & $\begin{array}{l}\text { TOTAL } \\
\text { OCCUP }\end{array}$ & $\begin{array}{l}\text { FACILITY } \\
\text { CONDIrION } \\
\text { RATING }\end{array}$ & $\begin{array}{l}\text { EXISTING } \\
\text { ANALYSIS } \\
\text { RATING }\end{array}$ \\
\hline FY 98 & & $241 \mathrm{UB}$ & VALVE PT & LMHC & U.FARM & & & & $\mathrm{PCx}$ & & & \\
\hline FY 98 & & $2410 \mathrm{C}$ & VALVE PIT & LMHC & U-FARM & & & & $\overline{\mathrm{PCX} x}$ & & & \\
\hline FY 98 & & $241 \mathrm{UD}$ & VALVE PTT & LMHC & U-FARM & & & & $\mathrm{PCx}$ & & & \\
\hline FY 98 & & 24IURISI & DNERSLON BOXES & LMHC & U-FARM & ' & & & $\mathrm{PCX}$ & & & \\
\hline FY 98 & & 241 URI52 & DNERSION BOXES & LMHC & U-FARM & & & & $\mathrm{PCX}$ & & & \\
\hline FY 98 & & 2A1URI53 & DNERSION BOXES & LMHC & U-FARM & & & & $\mathrm{PCX}$ & & & \\
\hline FY 98 & & $241 U R ! 54$ & DNERSION BOXES & LMHC & U.FARM & & & & $\mathrm{PCX}$ & & & \\
\hline FY 98 & & $2410 \times 154$ & DNERSION BOX & LMHC & U-FARM & & & & $\mathrm{PCX}$ & & & \\
\hline FY 93 & & $241 \mathrm{X} \times 302 \mathrm{~A}$ & CATCH TANK & LMHC & U.FARM & & & & $\mathrm{POX}$ & & & \\
\hline FY 98 & & $242 A 304$ & NTTRIC ACID UNLOADING STATION & $\begin{array}{ll}\text { PHMC } \\
\end{array}$ & & & & & $\mathrm{PCx}$ & & & \\
\hline$F Y 98$ & & $242 \mathrm{A350}$ & CATCH TANK & LMAC & & & & & $P C x$ & & & \\
\hline FY 98 & & $242 \mathrm{AB}$ & EVAPORATOR CONTROL BUILDING & RFSH & & & & & $\mathrm{PCy}$ & & & \\
\hline FY 98 & & $242 \mathrm{AC}$ & PIPEFITTERS SHOP · A FARM & PHMC & & & & 74 & $\mathrm{PCx}$ & & & \\
\hline FY 98 & & 2425 & EVAPORATOR FACILTYY & LMHC & & & & 766 & $\mathrm{PCx}$ & & & \\
\hline FY 98 & & $2425302 \mathrm{C}$ & ACID STORAGE TANK & LMIIC & & & & & $\mathrm{FOx}$ & & & \\
\hline FY 98 & & 2425702 & TURBINE BUILDING, VENTILATION & LMHC & & & & 13 & $\mathrm{PCX}$ & & & \\
\hline FY 98 & & $242 \mathrm{r}$ & WASTE DISPOSAL, EVAPORATOR BUILDING & LMHC & TX-FARM & & & 252 & $\mathrm{PCx}$ & & & \\
\hline FY 98 & & 242TISI & DNERSION BOX & LMHC & & & & & $\mathrm{PCx}$ & & & \\
\hline FY 98 & & 2427271 & EVAPORATOR CONTROL BUILDING & LMHC & & & & & $P C x$ & & & \\
\hline FY 98 & & 242T601 & CONTROL FACILITY & LMHC & & & & 62 & $\mathrm{PCX}$ & & & \\
\hline FY 98 & & $2422 \mathrm{TA}$ & VAULTWASTE RECEVING VAULT & LMHC & & & & & $\mathrm{PCX}$ & & & \\
\hline FY 98 & & $242 T \mathrm{~B}$ & VENT HOUSE & LMHC & & & & 18 & $\mathrm{PCX}$ & & & \\
\hline FY 98 & & $242 \mathrm{TC}$ & TANK FARM MICROCOMPUTER EQUIPMENT BLDG & LMHC & & & & 13 & PCX & & & \\
\hline FY $\mathscr{R}$ & & $243 G$ & GROUT FACILTYY & LMHC & & & & 11 & $\mathrm{PCx}$ & & & \\
\hline FY 98 & & $243 G 11$ & TGE CONTROL ROOM MODULE & LMHC & & & & & $\mathrm{PCx}$ & & & \\
\hline FY 98 & & $243 G 12$ & TGE CONTROL ROOM MODULE & LMHC & & & & & $\mathrm{PCx}$ & & & \\
\hline FY 98 & & $24361 \mathrm{~A}$ & GROUT PROCESSING FACILITY MOTOR PIT & LMHC & & & & 33 & $\mathrm{PCX}$ & & & \\
\hline FY 98 & & 24362 & GPF DRY BLEND HANDLING \& FEEDMODULE & LMHC & & & & $\$ 14$ & $\mathrm{PCX}$ & & & \\
\hline FY 98 & & 24363 & GPF ADDITIVES MODULE. & LMHC & & & & 514 & $\mathrm{PCX}$ & & & \\
\hline FY 98 & & 24364 & GPF CONTROL ROOM MODULE & LMHC & & & & 19 & $\mathrm{PCX}$ & & & \\
\hline FY 98 & & 24365 & GPF STANDBY GENERATOR & LMHC & & & & $\$ 14$ & $\mathrm{PCX}$ & & & \\
\hline FY 98 & & 24366 & GPF ELECTRICAL EQUTPMENT ROOM & LMHC & & & & & $\mathrm{PCx}$ & & & \\
\hline FY 98 & & 243600 & GROUT SEISMIC TRIP BULLDNG & LMHC & & & & & PCx & & & \\
\hline FY 98 & & 24368 & GPF FLTRATION MODULE EXHAUSTER MODULE & LMKC & & & & & $\mathrm{PCx}$ & & & \\
\hline FY 98 & & 243681 & GPF CONTROL ROOMWATER SERVICE BUILDNNG & LMHC & & & & 13 & $\mathrm{PCx}$ & & & \\
\hline
\end{tabular}




\begin{tabular}{|c|c|c|c|c|c|c|c|c|c|c|c|c|}
\hline $\begin{array}{l}\text { EVALU } \\
\text { SCHED }\end{array}$ & $\begin{array}{l}\text { PRIOITY } \\
\text { SCORE }\end{array}$ & IDENTIFIER & DESCRIPTION & CONTRA & PROJECT & $\begin{array}{l}\text { YEAR } \\
\text { BUILT }\end{array}$ & $\begin{array}{l}\text { YEAR } \\
\text { SURPLUS }\end{array}$ & $\begin{array}{l}\text { AREA SQ\# } \\
\text { METERS }\end{array}$ & $\begin{array}{c}\text { PERF.C } \\
\text { AT. }\end{array}$ & $\begin{array}{l}\text { TOTAL } \\
\text { OCCUP }\end{array}$ & $\begin{array}{l}\text { FACILTYY } \\
\text { CONDIIION } \\
\text { RATING }\end{array}$ & $\begin{array}{l}\text { EXISTING } \\
\text { ANALYSIS } \\
\text { RATING }\end{array}$ \\
\hline FY 98 & & 243682 & $\begin{array}{l}\text { GROUT PROCESSING FAC. PRESSURE REDUCING } \\
\text { VALVE PIT }\end{array}$ & LMHC & & & & s & $\mathrm{PCX}$ & & & \\
\hline FY 98 & & 23369 & GPF ELECTRICAL SUBSTATION & LMHC & & & & s14 & PCx & . & & \\
\hline FY 98 & & 243 STK1 & CATCH TANK & LMHC & & & & & POX & & & \\
\hline FY 98 & & $244 \mathrm{~A}$ & $\begin{array}{l}\text { WASTE VAULT AND INSTRUMENT HOUSE } \\
\text { RECENER TANK }\end{array}$ & LMHC & A. Fam & & & "11 & $\mathrm{PCX}$ & & & \\
\hline FY 98 & & $2 A A A R$ & $\begin{array}{l}\text { SLUDGE VAULT STORAGE AND PROCESSING } \\
\text { VAULT }\end{array}$ & LMHC & PUREX & $1 \% 66$ & & 347 & $P C x$ & & & \\
\hline FY98 & & 244ARISI & DNERSION BOX NO. 2, WASTETRANSFER LINE & LMHC & & & & & $\mathrm{PCx}$ & & & \\
\hline FY98 & & 244AR701 & EMERGENCY GENERATOR BULLDING & IMHC & & & & 7 & $\mathrm{PCx}$ & & & \\
\hline FY 98 & & 2A4ART2 & S00 KW STANDBY GENERATORENCLOSURE & IMHC & & & & & $\mathrm{PCx}$ & & & \\
\hline FY 98 & & 244AR712 & VAULT AIR LOCK \& LOAD OUTRUILDING & LMHC & & & & & $\mathrm{Pax}$ & & & \\
\hline FY98 & & 244AR715 & COMPRESSOR BUILDING & LMHC & & & & 47 & $\mathbf{P C X}$ & & & \\
\hline FY 98 & & $2448 X$ & SALT WELL RECENER VAULT & LMAHC & $B X-F_{2 m}$ & & & 13 & POX & & & \\
\hline FY 98 & & $244 \mathrm{BXR}$ & $\begin{array}{l}\text { WASTE DISPOSAL } \\
\text { VAULT,UNDERGROUNDRECEIVING VAULT }\end{array}$ & LMHC & BX.Fam & & & & $\mathrm{PCx}$ & & & \\
\hline FY 98 & & $244 \mathrm{CR}$ & $\begin{array}{l}\text { WASTE DISPOSAL VAULT, UNDERGROUND } 241 \mathrm{C} \\
\text { TANK FARMVAULTVAULT }\end{array}$ & LMHC & C-Farm & & & 220 & $\mathrm{PCX}$ & & & \\
\hline FY 98 & & 244CRWS1 & 244.CR FRENCH DRAIN & LMHC & & & & & $\mathrm{PCX}$ & & & \\
\hline FY 98 & & 2445 & WASTE LIFT STATION NAULT) RECENER TANK & LMHC & S.FARM & & & 514 & $\mathrm{PCx}$ & & & \\
\hline FY 98 & & 2445271 & INSTRUMENT CONTROL HOUSE & LMHC & & & & 18 & $\mathrm{PCX}$ & & & \\
\hline FY 98 & & $244 \mathrm{Tx}$ & $\begin{array}{l}\text { SALT WELL RECENER VAULTRECENVER } \\
\text { TANKSALT WELL RECENVER VAULT }\end{array}$ & LMHC & TX-FARM & & & 88 & $\mathrm{POX}$ & & & \\
\hline FY 98 & & 244TXR & WASTE DISPOSAL VAULT,UNDERGROUNDVAULT & LMHC & TX-FARM & & & & PCX & & & \\
\hline FY 98 & & 2440 & $\begin{array}{l}\text { SALT WELL RECEIVER VAULTRECENVER } \\
\text { TANKU-FARM DCRT }\end{array}$ & LMHC & U-FARM & & & 16 & $\mathrm{PCX}$ & & & \\
\hline FY 98 & & 24401 & INSTRUMENT BUILDING & LMHC & & & & & $\mathrm{PCX}$ & & & \\
\hline FY 98 & & $245 \mathrm{~A}$ & PDD/ASD LIFT STATION NO. 1 & PHMC & & & & & $\mathrm{PCX}$ & & & \\
\hline FY 98 & & $251 \mathrm{AX} 801$ & WATER SERVICE BURLDING & LMHC & & & & & PCX & & & \\
\hline FY 98 & & $251 \mathrm{~W}$ & $\begin{array}{l}\text { PRIMARY 220KV SWITCHNGG STATION,NO. OF } \\
\text { 200WELECTRICAL SUBSTATION }\end{array}$ & PHMC & & & & 388 & $\mathrm{PCX}$ & & & \\
\hline FY 98 & & $252 \mathrm{BY}$ & SUBSTATION $13.8 \mathrm{kV}$ & LMHC & & & & & PCX & & & \\
\hline FY 98 & & $252 \mathrm{E}$ & $\begin{array}{l}\text { ELECTRICAL SWTRCHING } \\
\text { STATION13.8YVELECTRICAL, SUBSTATION }\end{array}$ & PHMC & & & & 34 & $\mathrm{PCX}$ & & & \\
\hline FY 98 & & 2520 & $\begin{array}{l}13.8 \text { KV SUBSTATION, ON CONCRETESLAB } \\
\text { ELECTRICAL CSSS SUBSTATION }\end{array}$ & 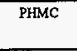 & & & & & $\overline{\mathrm{PC} x}$ & & . & \\
\hline FY 98 & & $252 \mathrm{w}$ & $\begin{array}{l}\text { ELECTRICAL SWTTCHING STATION } \\
\text { 13.8KVELECTRTCAL SUBSTATION }\end{array}$ & PHMC & T-RLANT & & & 34 & $\overline{P C X}$ & & & \\
\hline
\end{tabular}




\begin{tabular}{|c|c|c|c|c|c|c|c|c|c|c|c|c|}
\hline $\begin{array}{l}\text { EVALU } \\
\text { SCHED }\end{array}$ & $\begin{array}{l}\text { PRIOITY } \\
\text { SCORE }\end{array}$ & IDENTIFIER & DESCRIPTION & CONRA & PROJECT & $\begin{array}{l}\text { YEAR } \\
\text { BUILT }\end{array}$ & $\begin{array}{l}\text { YEAR } \\
\text { SURPLUS }\end{array}$ & $\begin{array}{l}\text { AREA SO } \\
\text { METERS }\end{array}$ & $\begin{array}{l}\text { PERF.C } \\
\text { AT. }\end{array}$ & $\begin{array}{l}\text { TOTAL } \\
\text { OCCUP }\end{array}$ & $\begin{array}{l}\text { FACILITY } \\
\text { CONDITION } \\
\text { RATING }\end{array}$ & $\begin{array}{l}\text { EXISTING } \\
\text { ANALYSIS } \\
\text { RATING }\end{array}$ \\
\hline FY 98 & & 261400 & $\begin{array}{l}\text { ENVIRONMENTAL } \\
\text { MONIORNGSTATIONENVIRONMENTAL } \\
\text { MONTORINGSTATION }\end{array}$ & PHMC & & & & 5 & $\mathrm{PCX}$ & & & \\
\hline FY98 & & $2614 \mathrm{WD}$ & MONITORING STATION & PHMC & & & & & $\mathrm{PCX}$ & & & \\
\hline FY 98 & & 2672 & RISER WO VALVE HOUSE & PHMC & PFP & & & 4 & PCX & & . & \\
\hline FY 98 & & $2 \pi \mathrm{IAC}$ & PUREX PATROL GUARD SHACKPUREX PARTROL & PHMC & PUREX & & & 2 & PEX & & & \\
\hline$\overline{F Y 98}$ & & $2703 E$ & CHEMICAL ENGINEERING LABORATORY & LMHC & & & & 354 & $\mathrm{PCX}$ & & & \\
\hline FY 93 & & $\overline{2 X 7 A R}$ & SLUDGE VAULT CHANGE HOUSE & LMHC & & & & 80 & $\mathrm{PCx}$ & & & \\
\hline FY 98 & & $2079 x$ & BUILDING CHANGE & LMHC & & & & 30 & $\mathrm{FCX}$ & & & \\
\hline FY 98 & & $2 \pi 78 x$ & CHANGE HOUSE & LMHC & & & & 132 & $P C x$ & & & \\
\hline FY 98 & & $208 \mathrm{AR}$ & SOLLED LAUNDRY STORAGE BUILDNG & LMHC & PUREX & & & 7 & $\mathrm{PCx}$ & & & \\
\hline FY 98 & & $270 \mathrm{w}$ & $\begin{array}{l}\text { UNDERGROUND CONDENSATENEUTRALIZATION } \\
\text { TANKNEUTRALIZATION TANK }\end{array}$ & LMHC & & & & & $\mathrm{PC} x$ & & & \\
\hline FY 98 & & $2712 \mathrm{~B}$ & $\begin{array}{l}\text { ELECTRICAL } \\
\text { INSTRUMENTATIONBUILDINGMONITORING } \\
\text { BUILDNGG }\end{array}$ & PHMC & B.PLANT & & & 2 & $\mathrm{PCX}$ & & & \\
\hline FY 98 & & $2722 \mathrm{~V}$ & ELECTRICAL INSTRUMENTATION BUILDING & RFSH & & & & & PCy & & & \\
\hline FY 98 & & $273 \mathrm{~W}$ & GARAGE OFFICE \& SERVICE & PHMC & & & & 387 & $\mathrm{POX}$ & & & \\
\hline FY 98 & & $2733 \mathrm{WB}$ & $\begin{array}{l}\text { REGULATED GARAGE AND HEAVY EQUIPMENT } \\
\text { REPAIR }\end{array}$ & LMHC & & & & $5 n$ & PCX & & & \\
\hline FY 98 & & $2713 \mathrm{WC}$ & PESTICIDE WASHWATER RECOVERYFACILTYY & PHMC & & & & 163 & $\mathbf{P C x}$ & & & \\
\hline FY $\$$ & & $2714 A R$ & SLUDGE VAULT GENERAL STORAGE BUILDING & LMHC & & & & 7 & $\mathrm{PCX}$ & & & \\
\hline FY 98 & & $2714 \mathrm{U}$ & WAREHOUSE V03 STORAGE BUILDNGG & PHMC & 003 & & & 401 & PCX & & & \\
\hline FY 9 & & $2715 \mathrm{AW}$ & STORAGE AND STAGING BUILDING & LMHC & & & & & $\mathrm{PCX}$ & & & \\
\hline FY98 & & 2715EA & DRUM STORAGE SHEDDRUM STORAGE SHED & PHMC & & & & 18 & $\mathbf{P C X}$ & & & \\
\hline FY 98 & & $2716 \mathrm{~A}$ & RM CHECK OUT STATION, NEARTUNNEL & $\begin{array}{l}\text { PHMC } \\
\text { PHM }\end{array}$ & PUREX & & & & $\mathrm{PCX}$ & & & \\
\hline FY 98 & & $2716 \mathrm{E}$ & $\begin{array}{l}\text { POWER MAINTENANCE STORAGEBUILDINGPOWER } \\
\text { MAINTENANACE STORAGEBUILDING }\end{array}$ & PHMC & & & & 7 & $\mathrm{PCX}$ & & & \\
\hline FY 98 & & $271 \mathrm{~A}$ & INSTRUMENT BLDG & PHMC & & & & & $\mathrm{PCX}$ & & & \\
\hline FY 98 & & $271 \mathrm{AN}$ & INSTRUMENT BLDG & PHMC & & & & & $\mathrm{PCX}$ & & & \\
\hline FY 98 & & $271 \mathrm{AP}$ & INSTRUMENT CONTROL BLDG & PHMC & & & & & $\mathrm{PCX}$ & & & \\
\hline FY 98 & & 271AW & INSTRUMENT BLDG & PHMC & & & & & $\mathrm{PCX}$ & & & \\
\hline FY 98 & & $271 \mathrm{CR}$ & SERVICE AND OFFICE BUILDING & LMHC & PUREX & & & 125 & $\mathrm{PCx}$ & & & \\
\hline FY 98 & & $2724 \mathrm{~A}$ & $\begin{array}{l}\text { RADIATION MONTIORING AND PROTECTNEE } \\
\text { CLOTHING FAC. }\end{array}$ & LMHC & & & & & $\mathrm{PCX}$ & & & \\
\hline FY 98 & & $222 A A Y$ & $\begin{array}{l}\text { RADIATION MONTORING AND PROTECTIVE } \\
\text { CLOTHNG FAC }\end{array}$ & LMHC & & & & 6 & $\overline{P C x}$ & & & \\
\hline FY 98 & & $272 A A Z$ & CHANGE HOUSE, TANK FARMS & LMHC & & & & 6 & $\mathrm{PCX}$ & - & & \\
\hline
\end{tabular}




\begin{tabular}{|c|c|c|c|c|c|c|c|c|c|c|c|c|}
\hline $\begin{array}{l}\text { EVALU } \\
\text { SCHED }\end{array}$ & $\begin{array}{l}\text { PRIOIrY } \\
\text { SCORE. }\end{array}$ & IDENTIFER & DESCRIPTION & CONTRA & PROJECT & $\begin{array}{l}\text { YEAR } \\
\text { BUILT }\end{array}$ & $\begin{array}{l}\text { YEAR } \\
\text { sURPLUS }\end{array}$ & $\begin{array}{l}\text { AREA SQH } \\
\text { METERS }\end{array}$ & $\begin{array}{c}\text { PERF.C } \\
\text { AT. }\end{array}$ & $\begin{array}{l}\text { TOTAL } \\
\text { OCCUP }\end{array}$ & $\begin{array}{l}\text { FACILITY } \\
\text { CONDITION } \\
\text { RATING }\end{array}$ & $\begin{array}{l}\text { EXISTING } \\
\text { ANALYSS } \\
\text { RATING }\end{array}$ \\
\hline FY 98 & & $222 A B$ & $\begin{array}{l}\text { RAD. MONITORING AND PROTECTIVE CLOTHING } \\
\text { FACIITTY }\end{array}$ & LMHC & TWRS & & & 6 & $\mathrm{PCx}$ & & & \\
\hline FY 98 & & $2724 \mathrm{BX}$ & $\begin{array}{l}\text { RAD. MONITORING AND PROTECTNE CLOTHING } \\
\text { FACLITY }\end{array}$ & LMHC & & & & 6 & $\mathrm{PCx}$ & & & \\
\hline FY 98 & & $222 \mathrm{ABY}$ & BUILDING CHECKOUT & LMHC & & & & 6 & $\mathrm{PCx}$ & & & \\
\hline FY98 & & $2724 \mathrm{C}$ & $\begin{array}{l}\text { RADIATION MONITORING AND PROTECTIVE } \\
\text { CLOTHING FAC. }\end{array}$ & LMHC & C-Famm & & & 6 & $\mathrm{PCX}$ & & & \\
\hline FY 98 & & $2724 \mathrm{CA}$ & $\begin{array}{l}\text { RADIATION MONTORING AND PROTECTIVE } \\
\text { CLOTHING FAC. }\end{array}$ & LMHC & CFarm & & & 6 & $P C X$ & & & \\
\hline FY 98 & & $27245 x$ & $\begin{array}{l}\text { RADIATION MONITORING AND PROTECTIVE } \\
\text { CLOTHING FAC. }\end{array}$ & LMHC & & & & 6 & $\overline{\mathrm{PCX}}$ & & & \\
\hline FY98 & & $2724 S Y$ & $\begin{array}{l}\text { RADIATION MONTORING AND PROTECTIVE } \\
\text { CLOTHING FAC. }\end{array}$ & LMHC & & & & 6 & $\mathrm{PCx}$ & & & \\
\hline FY 98 & & $2724 \mathrm{~T}$ & $\begin{array}{l}\text { RADIATION MONTIORING AND PROTECTIVE } \\
\text { CLOTHING FAC. }\end{array}$ & LMHC & & & & 6 & $\mathrm{PCX}$ & & & \\
\hline FY 98 & & $2724 x$ & $\begin{array}{l}\text { RADIATION MONTORING AND PROTECTNEE } \\
\text { CLOTHING FAC. }\end{array}$ & LMHC & & & & 6 & $\mathrm{PCX}$ & & & \\
\hline FY 98 & & $272 a \mathrm{TXA}$ & $\begin{array}{l}\text { RADIATION MONTORING AND PROTECTIVE } \\
\text { CLOTHING FAC. }\end{array}$ & LMHC & & & & 6 & $\mathrm{PQO}$ & & & \\
\hline PY98 & & $2724 \times \mathrm{XB}$ & $\begin{array}{l}\text { RADIATION MONITORING AND PROTECTRVE } \\
\text { CLOTHING FAC. }\end{array}$ & LMHC & & & & 6 & 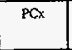 & & & \\
\hline FY 98 & & 27240 & CHECKOUT BUILDING & LMHC & & & & 6 & $\mathrm{PCX}$ & & & \\
\hline FY 98 & & $2724 \mathrm{UA}$ & $\begin{array}{l}\text { RADIATTON MONTTORING ANDPROTECTNE } \\
\text { CLOTHING FAC }\end{array}$ & LMHC & & & & & $\mathrm{PCX}$ & & & \\
\hline FY 98 & & $222 \pi \mathrm{NA}_{\mathrm{A}}$ & SODIEM STORAGE BUILDING & LMHC & & & & 248 & $\mathrm{POX}$ & & & \\
\hline FY 98 & & $2 n \mathrm{~A}$ & MAINTENANCE STORAGE & LMHC & PUREX & & & 44 & $\mathrm{PCX}$ & & & \\
\hline FY 98 & & $272 \mathrm{AW}$ & TANK FARM OPERATIONS SUPPORT FACRLTTY & LMHC & & & & 1396 & $\mathrm{PCX}$ & & & \\
\hline FY 98 & & 272AWLO & $\begin{array}{l}\text { CALIBRATION SOURCE } \\
\text { STORAGEBULDENGALIBRATION SOURCE } \\
\text { STORAGEBUIDINGG }\end{array}$ & LMHC & & & & & $\overline{\mathrm{PCx}}$ & & & \\
\hline FY 98 & & $27 \mathrm{BC}$ & $\begin{array}{l}\text { CONSTRUCTION MULTICRAFT } \\
\text { STRRAGECONSTRUCTION STORAGE BUILDING }\end{array}$ & PHMC & & & & 232 & $\mathrm{PCX}$ & & & \\
\hline FY 98 & & $272 \mathrm{EA}$ & SWP CHANGE SHELTER & PHMC & & & & 4 & $\mathrm{PCX}$ & & & \\
\hline FY 98 & & 2725 & MAINTENANCE SHOP MACHINE SHOP & LMHC & & & & 421 & $\mathrm{PCx}$ & & & \\
\hline FY98 & & $2 \pi 2 \mathrm{WA}$ & $\begin{array}{l}\text { TANK FARM SUPPORT FACILTTY TANK FARM } \\
\text { OPERDOOOW }\end{array}$ & LMHC & & & & 1738 & $\mathrm{PCX}$ & & & \\
\hline FY 98 & & $2734 \mathrm{EA}$ & GAS CYLINDER STORAGE BUILDING & PHMC & & & & & $P C x$ & & & \\
\hline FY 98 & & $273 A N$ & SERVICE BLDG & PHMC & & & & & $\mathrm{PCX}$ & & & \\
\hline FY 98 & & $273 A P$ & COMPRESSOR BLDG & PHMC & . & & & & $\mathrm{PCX}$ & & & \\
\hline FY 9.3 & & $273 \mathrm{AW}$ & SERVICE BLDG & PHMC & & & & & $P(x$ & & & $\cdot$ \\
\hline FY 98 & & 273EA & STORAGE YARD & LMHC & & & & & $\mathrm{PCX}$ & & & \\
\hline
\end{tabular}




\begin{tabular}{|c|c|c|c|c|c|c|c|c|c|c|c|c|}
\hline $\begin{array}{l}\text { EVALU } \\
\text { SCHED }\end{array}$ & $\begin{array}{l}\text { PRIOITY } \\
\text { SCORE }\end{array}$ & IDENTIFIER & DESCRIPIYON & CONTRA & PROJECT & $\begin{array}{l}\text { YEAR } \\
\text { BUILT }\end{array}$ & $\begin{array}{l}\text { YEAR } \\
\text { SURPLUS }\end{array}$ & $\begin{array}{l}\text { AREA SQ\# } \\
\text { METERS }\end{array}$ & $\begin{array}{l}\text { PERT.C } \\
\text { AT. }\end{array}$ & $\begin{array}{l}\text { TOTAL } \\
\text { OCCUP }\end{array}$ & $\begin{array}{l}\text { FACILTTY } \\
\text { CONDIIION } \\
\text { RATUNG }\end{array}$ & $\begin{array}{l}\text { EXTSTING } \\
\text { ANALYSIS } \\
\text { RATING }\end{array}$ \\
\hline FX 98 & & $274 A 2$ & $\begin{array}{l}\text { RADIATION MONISORING AND PROTECTIVE } \\
\text { CLOTHING FAC. }\end{array}$ & PHMC & & & & & $P C x$ & & & \\
\hline FY 98 & & $2802 \mathrm{AR}$ & SI,UDGE VAULT STEAM DISTRIRUTIONSYSTEM - & LMHC & & & & & $\mathrm{PCx}$ & & & \\
\hline FY 98 & & $2803 \mathrm{AR}$ & COMPRESSEO AIR DISTRIBUTIONSYSTEM & LMHC & & & & & $\mathrm{PCx}$ & & & \\
\hline $\mathrm{FY} 98$ & & 282.ED & STANDBY GENERATOR & PHMC & & & & & $\mathrm{PCX}$ & & & \\
\hline FY 98 & & $282 \mathrm{ND}$ & ST ANDBY GENERATOR & PHMC & & & & & $\mathrm{PCx}$ & & & \\
\hline FY 98 & & 283 WB & EQUALIZATION BASIN \& PUMP STATION & PHMC & & & & & $\mathrm{PCX}$ & & & . \\
\hline FY 98 & & $\frac{2 B S W}{290 ! A R}$ & SLUDGEE VAULT WATER STORAGEPIPING & $\frac{\text { PHMC }}{\text { LMHC }}$ & cwc & & & $\rightarrow$ & $\mathrm{PCX}$ & & & \\
\hline FY 98 & $\cdot$ & 2904AR & SLUDGE VAULT PROCESS SEWERSYSTEM & LMHC & & & & & $\mathrm{PC} x$ & & & \\
\hline FY 98 & & $291 A D$ & $\begin{array}{l}\text { FILTER PTY AND STACKEXHAUST FUTER } \\
\text { BUILDING }\end{array}$ & PHMC & PUREX & & & 17 & $\frac{\mathrm{PCx}}{\mathrm{PCX}}$ & & & \\
\hline FY 98 & & $291 \mathrm{Al}$ & BUILDNG & PHMC & PUREX & & & & & & & \\
\hline FY 98 & & $291 C R$ & RECOVERY FACILITIES IN 2AIC TANK FARM STACK & LMHC & & & & 9 & PCX & & & . \\
\hline FY 98 & & 292AR & $\begin{array}{l}\text { FILTER PTT AND INSTRUMENT HOUSE VESSEL } \\
\text { VENT STACK }\end{array}$ & LMHC & & & & 7 & $P C x$ & & & \\
\hline FY 98 & & 295A! & CRIB SAMPLER HOUSE & PHMC & & & & & & & & \\
\hline$\frac{\text { FY 98 }}{\text { FY 98 }}$ & & $290 \mathrm{~A} 13$ & $\begin{array}{l}\text { STACK, 24AAR VAULT CANYON/CELLS } \\
\text { VENTILATION }\end{array}$ & LMHC & & & & & $\mathrm{PCx}$ & & & \\
\hline & & & & LMHC & & & & & PCX & & & \\
\hline FY 98 & & 296126 & $\begin{array}{l}\text { STACK, 244A DC REC'R TKIANNULUS } \\
\text { VENTILATION }\end{array}$ & LMHC & & & & & $\mathrm{PCX}$ & & & \\
\hline FY 98 & & $296 \mathrm{~A} 27$ & STACK, 204AR UNLOAD RM/SUMP TK VENT & LMHC & & & & & & & & \\
\hline & & & & & & & & & $P C x$ & & & \\
\hline FY 98 & & $296 \mathrm{~A} 40$ & STACK, AP TK FM PRIMARY TANK VENTILATION & LMHC & & & & & & & & \\
\hline FY 98 & & 2964,42 & AGNG WASTE TANK STACK BUILT PROIECT W-030 & LMHC & & & . & & $\mathrm{PCx}$ & & & \\
\hline
\end{tabular}




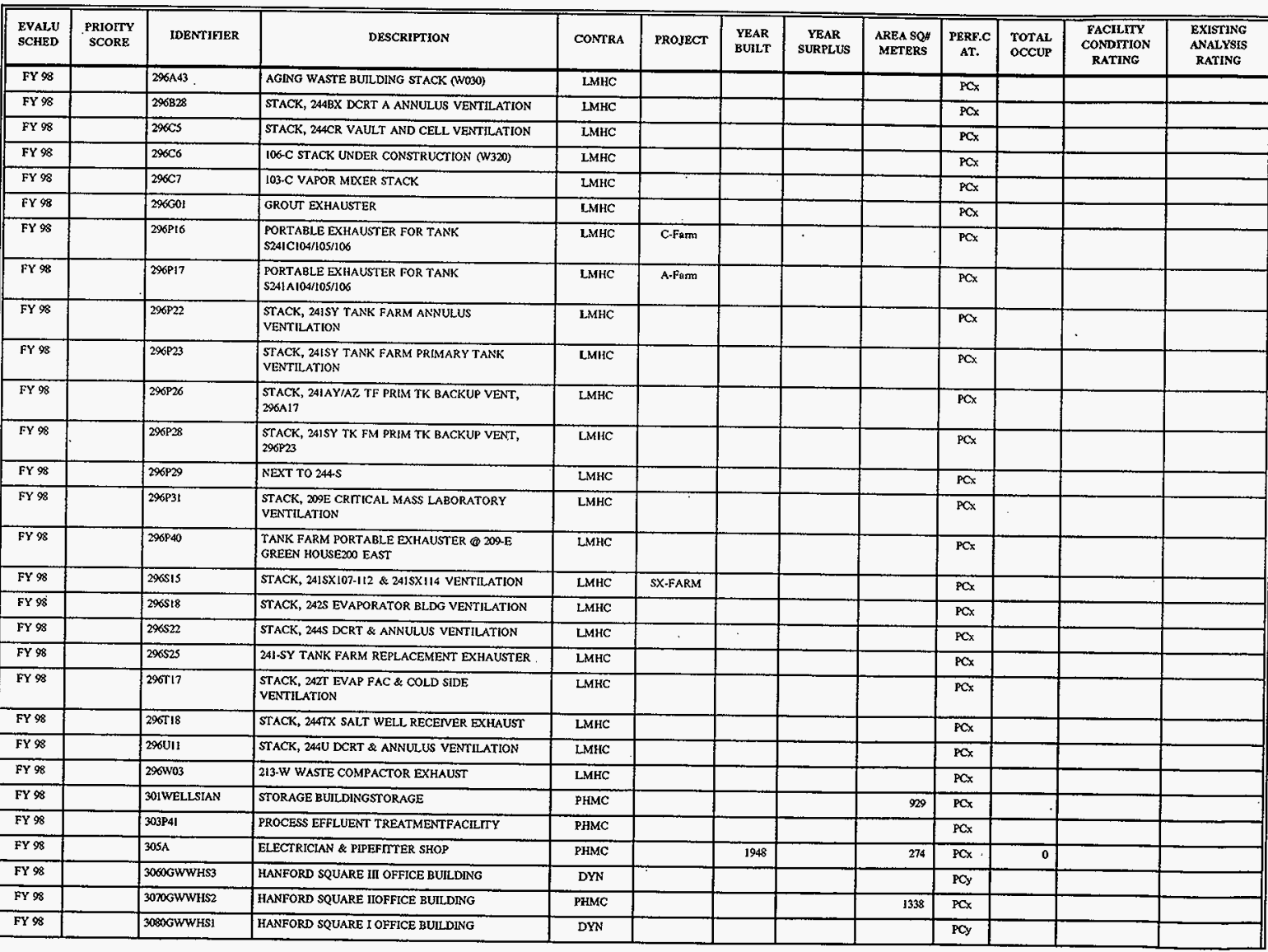




\begin{tabular}{|c|c|c|c|c|c|c|c|c|c|c|c|c|}
\hline $\begin{array}{l}\text { EVALU } \\
\text { SCHED }\end{array}$ & $\begin{array}{l}\text { PRIOIrY } \\
\text { SCORE }\end{array}$ & IOENTIFIER & DESCRIPTION & CONTRA & PROJECT & $\begin{array}{l}\text { YEAR } \\
\text { BUILT }\end{array}$ & $\begin{array}{c}\text { YEAR } \\
\text { SURPLUS }\end{array}$ & $\begin{array}{l}\text { AREA SQH } \\
\text { METERS }\end{array}$ & $\begin{array}{l}\text { PERF.C } \\
\text { AT. }\end{array}$ & $\begin{array}{l}\text { rorax } \\
\text { occur }\end{array}$ & $\begin{array}{l}\text { FACILITY } \\
\text { CONDPTION } \\
\text { RATING }\end{array}$ & $\begin{array}{l}\text { EXISTING } \\
\text { ANALYSIS } \\
\text { RATING }\end{array}$ \\
\hline FY 98 & . & 30906WWHS4 & HANFORD SQUARE TVOFFICE BUILDING & PHMC & & & & 1020 & $\overline{P C x}$ & & & \\
\hline FY 98 & & 3100GWW & $\begin{array}{l}3100 \text { GEO. WASH. WAY (RICHLAND)OFFICE } \\
\text { BUILDING }\end{array}$ & $\begin{array}{l}\text { PHMC } \\
\end{array}$ & & & & 879 & $P C x$ & & & \\
\hline FY 98 & & 3105 & DRUM STORAGE AREA - TEDF & PHMC & & & & & $\mathrm{PCX}$ & & & \\
\hline FY 98 & & 313 & REACTOR FUEL MANUFACTURING BUILDING & PHIMC & 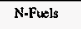 & & & 733 & $P C X$ & & & \\
\hline FY 98 & & 317 & CALIBRATION AND STANDARDSFACILTYY & PHMC & & & & & $P C x$ & & & \\
\hline FY 98 & & 3218 & $\begin{array}{l}\text { MODEL HEAT LOOP, PART OF 321BUILDINGMODEL } \\
\text { YEST LOOP }\end{array}$ & PHMC & & & & $16 !$ & $P C X$ & 0 & & \\
\hline FY 98 & & 3210 & SEISMIC TESTING FAC. PART OF 32IBLDG & PHMC & & & & & $\mathrm{PCX}$ & & & \\
\hline FY98 & & 331 IWCLEAR & $\begin{array}{l}3311 \text { W, CLEARIWATER, KENNEWICKOFFICE - } \\
\text { LEASED }\end{array}$ & PHMC & & & & 342 & $P C X$ & & & \\
\hline FY 98 & & 3408 & FMIT COOLNG TOWER & PHMC & & & & & $\mathrm{PCX}$ & & & \\
\hline FY 98 & & $35 \mathrm{FA}$ & $\begin{array}{l}\text { METER AND TESTING BUILDINGELECTRICAL } \\
\text { SUBSTATION }\end{array}$ & PHMC & & 1952 & & 26 & $\mathrm{PCx}$ & 0 & & \\
\hline FY 98 & & $35 \mathrm{siB}$ & $\begin{array}{l}\text { METER TLSTING AND SWTTCHGEARFACILSTY, } \\
\text { BSSAELECTRICAL SUBSTATION }\end{array}$ & PHMC & N-Fuels & 1970 & & 149 & $\overline{P C x}$ & 0 & & \\
\hline FY 98 & & $352 \mathrm{E}$ & $\begin{array}{l}\text { SWITCH STATION EAST SIDEELECTRICAL } \\
\text { SUBSTATION - EAST SIDE }\end{array}$ & PHMC & & 1972 & & 149 & $\mathrm{PCX}$ & 0 & & \\
\hline FY 98 & & $352 \mathrm{~F}$ & $\begin{array}{l}\text { ELECTRICAL SUBSTATION } 2.4 \text { KVELCCTRICAL } \\
\text { SUBSTATION }\end{array}$ & PHMC & & 1978 & & 56 & $\overline{P C X}$ & 0 & & \\
\hline FY 98 & & 360 & SANITARY SEWER CONTROL BUILDING & PHMC & & & & 173 & $P C x$ & & & \\
\hline FY 98 & & $3607 \mathrm{~A}$ & PUMPHOUSEPUMPHOUSE & PHMC & & & & 9 & $\mathrm{PCX}$ & 0 & & \\
\hline FY 98 & & $3621 E$ & UNINTERRUPTIBLE POWER SUPPLYBUILDING & PHMC & & & & & $P C X$ & & & \\
\hline FY 98 & & 37010 & OFFICE BUILDINGGAURD STATION & PHMC & & 1979 & & 125 & $\mathrm{PCX}$ & 0 & & \\
\hline FY 98 & & 3204 & INSULATORS STORAGE STORAGE BUILDING & PHMC & N-Fivels & 1944 & & 74 & $\mathrm{PCX}$ & 0 & & \\
\hline FY 98 & & 3705 & $\begin{array}{l}\text { PHOTOGRAPHY BUILDANGPHOTOGRAPHY } \\
\text { BUILDENG }\end{array}$ & PHMC & N-fuels & 1944 & & 648 & $P C x$ & is & & \\
\hline FY 98 & & $3706 \mathrm{~A}$ & $\begin{array}{l}\text { VENTILATION EQUIP RM FOR } \\
\text { 370BBULLDINGVENTILATION FOR } 3706\end{array}$ & PHMC & & 1944 & & 140 & $\mathrm{PCX}$ & 0 & & \\
\hline FY 98 & & 3 MTE & CONSTRUCTION STORAGE STORAGE BUILDING & PHMC & & 1944 & & 34 & $\mathrm{PCx}$ & 0 & & \\
\hline FY 98 & & 3707H & CHANGE HOUSECHANGE HOUSE & PHMC & & 1979 & & 112 & $\mathrm{PCX}$ & 0 & & \\
\hline FY 98 & & 3714 & ORGANIC CHEMISTRY LABORATORY & PHMC & & 1955 & & 107 & $\mathrm{PCX}$ & 0 & & \\
\hline FY 98 & & 3717 & $\begin{array}{l}\text { SPARE PARTS WAREHOUSE WAREHOUSE } \\
\text { BULDING }\end{array}$ & PHMC & 340.WHF & 1944 & & 897 & $P C X$ & 0 & & \\
\hline FY 98 & & $3718 \mathrm{C}$ & STORAGE BUILDINGSTORAGE BUTLDING & PHMC & & 1952 & & 416 & $\mathbf{P C X}$ & 0 & & \\
\hline FY 98 & & $3718 \mathrm{~N}$ & INSULATION SHOPELECTRICAL SHOP & PHMC & & 1971 & & 268 & $\mathrm{PCX}$ & 2 & & \\
\hline FY 98 & & 3719 & COMPUTER FACILTYTELECOMMUNICATTONS HUB & PHMC & N-Futs & F78 & & 200 & $\mathrm{PCX}$ & 2 & & \\
\hline FY 98 & & 3722 & FABRICATION SHOPCONSTRUCTION SHOP & PHMC & N.Futs & 1944 & & 463 & $\mathrm{PCX}$ & 0 & & \\
\hline
\end{tabular}




\begin{tabular}{|c|c|c|c|c|c|c|c|c|c|c|c|c|}
\hline $\begin{array}{l}\text { EVACU } \\
\text { SCHED }\end{array}$ & $\begin{array}{l}\text { PRIORTYY } \\
\text { SCOKE }\end{array}$ & IDENTIFIER & DESCRIPTION & CONTRA & PROJECT & $\begin{array}{l}\text { YEAR } \\
\text { BUILT }\end{array}$ & $\begin{array}{l}\text { YEAR } \\
\text { SURPLUS }\end{array}$ & $\begin{array}{l}\text { AREA SQ\# } \\
\text { METERS }\end{array}$ & $\begin{array}{c}\text { PERF.C } \\
\text { AT. }\end{array}$ & $\begin{array}{l}\text { Toral } \\
\text { occuP }\end{array}$ & $\begin{array}{l}\text { FACILITY } \\
\text { CONDITION } \\
\text { RATING }\end{array}$ & $\begin{array}{l}\text { EXISTING } \\
\text { ANALYSIS } \\
\text { RATING }\end{array}$ \\
\hline FY 98 & & 3723 & $\begin{array}{l}\begin{array}{l}\text { GEOTECHNICAL HIGH-BAY GEOTECHNICAL } \\
\text { HIGH-BAY }\end{array} \\
\end{array}$ & PHMC & & 1980 & & 297 & $\mathrm{PCX}$ & 0 & & \\
\hline FY 98 & & $3746 \mathrm{D}$ & $\begin{array}{l}\text { TECHNICAL SERVICE ANNEXTECHNICAL SERVICE } \\
\text { ANNEX }\end{array}$ & PHMC & M-Fivels & 1948 & & 117 & $\mathrm{PCX}$ & 0 & & \\
\hline PY98 & & 3747 & $\begin{array}{l}\text { FUSION MATERIAL IRRADIATION TESTFMMT) } \\
\text { FACLLITYFUSON MATERIAL IRRADIATION } \\
\text { TESTFACILTY }\end{array}$ & $\begin{array}{l}\text { PHMC } \\
\end{array}$ & & & & & $\overline{P C x}$ & & & \\
\hline$F Y 98$ & & $376 \mathrm{t}$ & $\begin{array}{l}\text { CONFERENCE TRAINING BUILDINGCONFERENCE } \\
\text { TRAINING }\end{array}$ & PHMC & & & & & $\mathrm{PCX}$ & & & \\
\hline FY98 & & 377 & OFFICE BUILDNG & PHMC & & & & & $\mathrm{PCX}$ & & & \\
\hline$F Y \mathscr{S}$ & & 3772 & OFFICE BUILDING & PIIMC & & & & & $\mathrm{PCX}$ & & & \\
\hline FY 98 & & 4166 & TRANSFER STORAGE BUILDING, FMEF & PHMC & & & & & $\mathrm{PCx}$ & & & \\
\hline FY 98 & & 420GOLFCLUB & 430 GOLF CLUB ROAD, LACEY WA. & PHMC & & & & 116 & PCX & 0 & & \\
\hline FY 98 & & $4608 \mathrm{~B}$ & $\begin{array}{l}\text { CONTROL STRUCT, \& PROCESS SEWERSAMPLING } \\
\text { STATIONSEWER SAMPLING STATION }\end{array}$ & DYN & & & & 514 & $\overline{\mathrm{PCy}}$ & & & \\
\hline FY 98 & & $40(223$ & METEROLOGY BUILDING AND TOWER & PHMC & & & & & $\mathrm{PCX}$ & & & \\
\hline FY 98 & & $4717 \mathrm{~A}$ & CASK LOADING STATION (PART OF 4717) & PHMC & & & & & PCy & & & \\
\hline$\overline{F Y 98}$ & & $4718 \mathrm{TC}$ & OFFICE, TEMPORARY & PHMC & & & & & $\mathrm{PCX}$ & & & \\
\hline FY 98 & & $4732 \mathrm{~A}$ & WAREHOUSE WAREHOUSE & PHMC & ?FFTF & & & 1394 & PCX & & & \\
\hline FY 98 & & 4760 & CONSTRUCTION SHOP ELECTRICAL SHOP & PIIMC & ?FFTF & & & 372 & $\overline{P C x}$ & & & \\
\hline FY98 & & $47917 \mathrm{C}$ & \begin{tabular}{|l|} 
WAREHOUSE GENERAL STORAGE \\
\end{tabular} & BWHC & FFTF & & & 134 & $\mathrm{PC} x$ & & & \\
\hline$\overline{F Y 98}$ & & 4814 & $\begin{array}{l}\text { SPECIAL, TOOLS WAREHOUSE WAREHOUSE } \\
\text { BUILDING }\end{array}$ & BWHC & FFTF & & & 465 & $\mathrm{PC}$ & & & \\
\hline FY 98 & & 4831 & $\begin{array}{l}\text { LAYDOWN HAZARDOUS STAGING FLAMMABLE } \\
\text { STORAGE BUILDING }\end{array}$ & BWHC & FFTF & & & 137 & $\mathrm{PCX}$ & & & \\
\hline FY98 & & WO1WILLAAMS & $\begin{array}{l}\text { HAPO BUILDING (60) } \\
\text { WILLIAMS, RICHLAND)OFFICE BULLDNG }\end{array}$ & DYN & & & & & PCy & & & \\
\hline FY 98 & & 604 & YAKIMA BARRICADE, PATROLCHECKING STATION & PHMC & & & & 28 & $\mathrm{PCX}$ & & & \\
\hline FY 98 & & $60 \mathrm{dH}$ & $\begin{array}{l}\text { PATROL UTILTYY BUILDINGPATROL UTILTTY } \\
\text { BULLING }\end{array}$ & PHMC & & & & 2 & $\overline{P C X}$ & & & \\
\hline FY 98 & & 607 & BATCH PLANT LAB STORAGE - LESS THAN $\infty$ DAY & PHMC & & & & 110 & $\mathrm{PCx}$ & & & \\
\hline $\mathrm{FY} 98$ & & 617 & BWIP CORE STORAGE FACILITY & PHMC & & & & 1672 & $\mathrm{PCx}$ & & & \\
\hline FY 98 & & 6221NA & 62IN TOWER BUIDDNG & PHMC & & & & & $\mathrm{PCy}$ & & & \\
\hline FY 98 & & $6223 \mathrm{~A}$ & 6223 TOWER BULLDING & PHMC & & & & & PCy & & & \\
\hline FY 98 & & $6224 \mathrm{~A}$ & 6224 TOWER BULLDNG & PHMC & & & & & PCy & & & \\
\hline FY 98 & & 622E & STORAGE BUILDING STORAGE BUILDNG & PHMC & & & & 94 & $\mathrm{PCx}$ & & & \\
\hline FY 98 & & 623 & STORAGE BUILDING, GABLE MOUNTANN & PHMC & & & & 17 & $\mathrm{PCx}$ & & & \\
\hline FY 98 & & 6291 & FUELING FACLLTYYUELLNG FACIITTY & PHMC & & & & 26 & $\mathrm{PCx}$ & & & \\
\hline
\end{tabular}




\begin{tabular}{|c|c|c|c|c|c|c|c|c|c|c|c|c|}
\hline $\begin{array}{l}\text { EVALU } \\
\text { SCHED }\end{array}$ & $\begin{array}{l}\text { PRIOITY } \\
\text { SCORE }\end{array}$ & IDENTIFIER & DESCRIPTION & CONTRA & PROJECT & $\begin{array}{l}\text { YEAR } \\
\text { BUILT }\end{array}$ & $\begin{array}{l}\text { YEAR } \\
\text { SURPLUS }\end{array}$ & $\begin{array}{l}\text { AREA SQ" } \\
\text { METERS }\end{array}$ & $\begin{array}{l}\text { PERF.C } \\
\text { AT. }\end{array}$ & $\begin{array}{l}\text { TOTAL } \\
\text { OCCUP }\end{array}$ & $\begin{array}{l}\text { FACIITY } \\
\text { CONDITION } \\
\text { RATING }\end{array}$ & $\begin{array}{l}\text { EXISTING } \\
\text { ANALYSIS } \\
\text { RATING }\end{array}$ \\
\hline FY 98 & & $6652 \mathrm{~L}$ & $\begin{array}{l}\text { RATTLESNAKE MTN (FORMERLYYMERGENCY } \\
\text { CONTROL CNTR)UNDERGROUND } \\
\text { EMERGENCYRELOCATION CENTER }\end{array}$ & PHiMC & & & & 669 & $\mathrm{PCX}$ & & & \\
\hline FY 98 & & $6052 \mathrm{P}$ & GENERATOR BUILDINGGENERATOR BUILDING & PHMC & & & & 84 & $P C x$ & & & \\
\hline FY 98 & & $\cos 2 \mathrm{R}$ & ACID STORAGE SHED & PHMC & & & & 4 & $\mathrm{PCX}$ & & & \\
\hline FY98 & & 60525 & SENTRY SHEDSENTRY SHED & PHMC & & & & 4 & FCx & & & \\
\hline FY 98 & & $6053 \mathrm{~A}$ & TEDF PUMP STATION $B 3$ & PHMC & & & & & $\mathrm{PCX}$ & & & \\
\hline FY 98 & & 712 & $\begin{array}{l}\text { RECORDS CENTER, PRINTING ANDREPRODUCTION } \\
\text { PLANTRECORDSPRINTINGMALL }\end{array}$ & $\begin{array}{l}\text { PHMC } \\
\end{array}$ & & & & 1825 & $\overline{\mathrm{PCX}}$ & & & \\
\hline FY 98 & & $712 B$ & IRM LITIGATION SUPPORT FACILTYY & PHMC & & & & 172 & $P C x$ & & & \\
\hline$\overline{F Y 98}$ & & 747 & $\begin{array}{l}\text { ENVIRONMENTAL HEALTH } \\
\text { SCIENCESEUILDNGENVIRONMENTAL HEALTH } \\
\text { SCIENCESBULLDNG }\end{array}$ & PHMC & & & & 724 & $\mathrm{PCX}$ & & & \\
\hline FY 98 & & 7478 & $\begin{array}{l}\text { LNVIRONMENTAL HEALTH SCIENCESBUILDING } \\
\text { ANNEXENVIRONMENTAL HEALTH } \\
\text { SCIENCESANNEX }\end{array}$ & $\begin{array}{l}\text { PHMC } \\
\end{array}$ & & & & 231 & $P C x$ & & & \\
\hline FY 93 & & MCC241AW & MOTOR CONTROL CLENTER & LMHC & & & & & $\mathrm{PCX}$ & & & \\
\hline FY 98 & & M0023 & MOBLEE OFFICE Q 202AMOBILE OFFICE (202A) & $\overline{B W H C}$ & & & & 515 & $\mathrm{PCy}$ & & & \\
\hline FY 98 & & M0046 & MOBILE OFFICE (318 TRL, 3)MOBILE OFFICE (318T3) & DESH & & 1978 & & 515 & $\mathrm{PCY}$ & & & \\
\hline FY 98 & & MO114 & CHANGE TRAILER G 241BY & LMHC & & & & 28 & $\mathrm{PCX}$ & & & \\
\hline$F Y 98$ & & MO286 & MOBLLE OFFICE $Q 2727 E$ MOBILE OFFICE & DYN & & & & 1030 & $\mathrm{PCY}$ & & & \\
\hline FY 98 & & MO293 & MOBILE OFFICE $Q$ 172SK (SPENT FUEL) & DESH & $100 \mathrm{~K}$ & & & 859 & $\mathrm{PCY}$ & & & \\
\hline FY 98 & & M0295 & TRAILER & LMHC & & & & 7 & $\mathrm{PCx}$ & & & \\
\hline FY 98 & & M0305 & MOBILE OFFICE $325 \mathrm{~T}$.1MOBN.E OFFICE (32STI) & BWHC & & & & & $\mathrm{PCY}$ & & & \\
\hline FY 98 & & MO319 & CHANGE TRAILER (TANK FARMS) 241EX & LMHC & & & & 28 & $\mathrm{PCx}$ & & & \\
\hline FY 98 & & M0320 & WOMENS CHANGE ROOM TRAILER @242S & LMHC & & & & 28 & $\mathrm{PCX}$ & & & \\
\hline FY98 & & 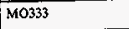 & STORAGE TRAILER @ 2W TANK FARMSU-12 & LMHC & & & & 28 & $\mathrm{PCX}$ & & & \\
\hline FY 98 & & M0363 & MOBILE OFFICE @ 24ISX TANK FARM & LMHC & & & & 18 & $P C x$ & & & \\
\hline$F Y 98$ & & MO404 & MOBILE OFFICE $Q 1163$ MOBILE OFFICE $(1160)$ & DYN & & & & 687 & PCy & & & \\
\hline $\mathrm{FY} \mathscr{P B}$ & & MO405 & MOBILE OFFICE $\otimes$ PUREXMOBLE OFFICE - PUREX & BWHC & & & & 1288 & $\mathrm{PCY}$ & & & \\
\hline FY 98 & & MO409 & $\begin{array}{l}\text { ANALYTICAL LAB TRAILER Q PUREXMOBILE } \\
\text { OFFICE - PUREX }\end{array}$ & BWHC & & & & 343 & $\mathrm{PCy}$ & & & \\
\hline FY 98 & & M0439 & MOBILE CHANGEROOM $@$ AY TANKFARM & LMHC & & & & 65 & $\mathrm{PCX}$ & & & \\
\hline FY 98 & & MO447 & TRAILERMOBLE OFFICE & LMHC & & & & 9 & $\mathrm{PCX}$ & & & \\
\hline FY 98 & & MO450 & TRALERMOBLE OFFICE & LMHC & & & & 9 & $\mathrm{PCx}$ & & . & \\
\hline FY 98 & & M0451 & TRALERMOBLE OFFICE & IMHC & & & & 9 & $\mathrm{PCx}$ & & & \\
\hline FY 98 & & MO461 & TRAILER AT 101SY & IMHC & & & & 46 & $P C x$ & & & \\
\hline & & MO815 & CHANGE TRAILR 241 AP TANK FARM & LMHC & & & & 36 & $\mathrm{FCx}$ & & & \\
\hline
\end{tabular}




\begin{tabular}{|c|c|c|c|c|c|c|c|c|c|c|c|c|}
\hline $\begin{array}{l}\text { EVALU } \\
\text { SCHED }\end{array}$ & $\begin{array}{l}\text { PRrorry } \\
\text { SCORE }\end{array}$ & IDENTIFIER & DESCRIPTION & CONTRA & PROJECT & $\begin{array}{l}\text { YEAR } \\
\text { BUILT }\end{array}$ & $\begin{array}{l}\text { YEAR } \\
\text { SURPLUS }\end{array}$ & $\begin{array}{l}\text { AREA SQH } \\
\text { METERS }\end{array}$ & $\begin{array}{l}\text { PERF.C } \\
\text { AT. }\end{array}$ & $\begin{array}{l}\text { TOTAL } \\
\text { OCCUP }\end{array}$ & $\begin{array}{c}\text { FACILITY } \\
\text { CONDTIION } \\
\text { RATING }\end{array}$ & $\begin{array}{l}\text { EXISTING } \\
\text { ANALYSIS } \\
\text { RATING }\end{array}$ \\
\hline FY 98 & & M0816 & CHANGE TRALLER $244 \mathrm{~A}$ TANK FARM & LMHC & & & & 36 & $\overline{\mathrm{PCX}}$ & & & \\
\hline FY 98 & & M0817 & CHANGE TRAILER @ TX TANK FARM & LMHC & & & & 36 & PCX & & & \\
\hline FY 98 & & M0818 & CHANGE TRALLER @ 2A1AW TANK FARM & LMHC & & & & 36 & $\mathrm{PCX}$ & & & \\
\hline $\begin{array}{lll}\text { FY } 98 \\
\end{array}$ & & M0819 & CHANGE TRALER $@ S X$ TANK FARMC & LMHC & & & & 36 & 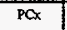 & & & \\
\hline FY 98 & & MO830 & CHANGE TRAILER $\bigcirc$ AN TANK FARM & LMHC & & & & 36 & $\overline{\mathrm{PC} x}$ & & & \\
\hline FY 98 & & M0821 & CHANGE TRAILER $@ 207 \mathrm{TT}$ TANK FARM & LMHC & & & & 36 & $\mathrm{PC} \times$ & & & \\
\hline FY 98 & & MOS22 & CHANGE TRAILER $₫ 2 A 1 \mathrm{C}$ TANK FARMC & LMHC & C.Famn & & & 36 & $\mathrm{PCX}$ & & & \\
\hline FY 98 & & Mo823 & CHANGE TRAILER $\oslash$ U TANK FARM & LMHC & & & & 36 & $\mathrm{PCX}$ & & & \\
\hline FY 98 & & Mo824 & CHANGE TRALLER $@ 241$ BX TANK FARM & LMHC & & & & 36 & $\mathrm{PCX}$ & & & \\
\hline FY 98 & & MO825 & CHANGE TRALLER $@ 241 \mathrm{AY}$ TANK FARM & LMHC & & & & 36 & $\overline{P C x}$ & & & \\
\hline FY 98 & & MO826 & CHANGE TRAILER @ W/O 243G GROUT & LMHC & & & & 36. & $\mathrm{PCx}$ & & & \\
\hline FY 98 & & MO852 & $\begin{array}{l}\text { MOBILE OFFICE } Q \text { 4TH } \& \\
\text { BALTMOREAKA:290EMOBILE OFFICE }\end{array}$ & DYN & & & & 429 & $\mathrm{PCY}$ & & & \\
\hline FY 98 & & MO904 & MOBILE OFFICE (FMT TRL 8 ) & LMHIC & & & & 125 & $\mathrm{POC}$ & & & \\
\hline FY 98 & & $\mathrm{PO} 013$ & LLESS THAN 90 DAY STORAGE(PORTABLE) & PHMC & & & & & $P C X$ & & & \\
\hline FY 98 & & SEWER/RLWS & RADIOACTIVE LLQUID WASTE SEWER & RFSH & & & & & $\overline{\mathrm{PCX}}$ & 0 & & \\
\hline FY 98 & & res6 & WEATHER PROTECTION FOR $242 Z$ & PHMC & & & & & $\mathrm{PCX}$ & & & \\
\hline FY 98 & & $\mathrm{X}_{4}$ & RAILROAD TOOL, SHED SHED & PHMC & & & & 15 & PCX & & & \\
\hline FY 98 & & $\mathrm{x} 8$ & MOTOR CAR SHEDGAN CAR STORAGE BUILDING & PHMC & & & & 15 & $\mathrm{PCX}$ & & & \\
\hline
\end{tabular}


HNF-SP-1175

APPENDIX D

COMPLIANCE BASELINE FOR EXISTING

BUILDINGS AND STRUCTURES THAT

ARE CANDIDATES FOR UPGRADE 
HNF-SP-1175

This page intentionally left blank. 
APPENDIX D. COMPLIANCE BASELINE FOR EXISTING BUILDINGS AND STRUCTURES THAT ARE CANDIDATES FOR UPGRADE. TOTAL NON-EXEMPT ASSETS $=$

\begin{tabular}{|c|c|c|c|c|c|c|c|c|c|c|c|c|}
\hline \multicolumn{2}{|c|}{ Trade-off schedule } & \multicolumn{2}{|c|}{ Bui lding/structure } & CNIR & Project & $\begin{array}{l}\text { Year } \\
\text { Built }\end{array}$ & $\begin{array}{l}\text { Year } \\
\text { surplus }\end{array}$ & $\begin{array}{c}\text { Area } \\
m^{2} 2\end{array}$ & $\begin{array}{l}\text { Performance } \\
\text { Category }\end{array}$ & $\begin{array}{c}\text { Max } \\
\text { Occupancy }\end{array}$ & $\begin{array}{c}\text { Cost of } \\
\text { Mitigation }\end{array}$ & $\begin{array}{l}\text { Retrof it } \\
\text { Complete }\end{array}$ \\
\hline start & Complete & Identifier & Name & & & & & & & & & \\
\hline
\end{tabular}


HNF-SP-1175

This page intentionally left blank. 


\section{DISTRIBUTION}

Number of copies

ONSITE

4

T. J. Conrads

H5-25

Central Files

B1-03

Document Processing Center

A3-94

Document Processing and

Distribution

A3-89 
HNF-SP-1175

This page intentionally left blank. 